UNIVERSIDADE DE BRASÍLIA INSTITUTO DE GEOCIÊNCIAS

PROGRAMA DE PÓS-GRADUACÃO EM GEOCIÊNCIAS APLICADAS

MODELO DE AVALIAÇÃO DA QUALIDADE DA ÁGUA UTILIZANDO GEOQUÍMICA E BIOINDICADORES.

AREA DE CONCENTRAÇÃO: HIDROGEOLOGIA E MEIO AMBIENTE

TESE DE DOUTORADO Nº26

SANDRO MORAIS PIMENTA

ORIENTADOR: PROF. DR. GERALDO RESENDE BOAVENTURA

BRASÍLIA-DF

JANEIRO, 2016 

BIOINDICADORES.

Tese apresentada ao Programa de Pós-graduação em Geociências Aplicadas da Universidade de Brasília, como requisito parcial para obtenção do título de Doutor em Geociências Aplicadas.

ORIENTADOR: PROF. DR. GERALDO RESENDE BOAVENTURA

Data da defesa: 18 de dezembro de 2015

Banca Examinadora:

Prof. Dr. Geraldo Resende Boaventura - Orientador (UnB-IG)

Prof ${ }^{a}$. Dr ${ }^{\mathrm{a}}$. Marlei de Fátima Pereira (IFG)

Prof. Dr. Wilson Thadeu Valle Machado (UFF/PPG-GEO)

Prof. Dr. Éder de Souza Martins (Embrapa)

Prof. Dr. Detlef Hans Gert Walde (UnB-IG) 
"Desde a aurora da civilização as pessoas não se dão por satisfeitas com a noção de que os eventos são desconectados e inexplicáveis. Sempre ansiamos por compreender a ordem subjacente do mundo."

Stephen Hawking 
Ao Programa de Pós-Graduação em Geociências Aplicadas, do Instituto de Geociências da Universidade de Brasília - UnB, pela oportunidade e estudos proporcionados, aos professores pela dedicação, empenho e profissionalismo apresentados na condução das disciplinas do programa.

Ao professor Dr. Geraldo Resende Boaventura, amigo e orientador, pela compreensão e apoio e por compartilhar experiência profissional e de vida.

À CAPES e ao CNPq, que auxiliaram no financiamento e desenvolvimento desta pesquisa.

Ao IFG Instituto Federal de Educação Ciência e Tecnologia de Goiás, pelo seu programa de incentivo a qualificação, concedendo licença, para dedicação a esta pesquisa.

Aos Professores Dr. Jeremie Garnier, Professora Dr ${ }^{\text {a }}$ Adriana Maria Coimbra Horbe, pela avaliação e crítica ao estudo.

Ao Laboratório de Geoquímica da Universidade de Brasília, pela utilização das instalações do laboratório, respectivas análises físico-químicas e dedicação de seus técnicos Myller e Fernando.

Aos amigos: Prof. Tiago Godoi Ribeiro, Prof. Alfredo Palau Peña; pelo apoio, auxílio em campo e contribuições de forma direta e indireta nos momentos de dificuldades. Aos colegas de instituição e aos amigos que fiz no doutorado, pelo apoio e auxilio no desenvolvimento da pesquisa. A todos que diretamente e indiretamente me ajudaram a concluir este projeto.

Em especial, agradeço aos meus pais José da Rocha Pimenta e Rosenilda Morais Pimenta, irmãos e familiares que me ajudaram e me incentivaram nos momentos difíceis. À Aline de Moraes Rocha pelos seus conselhos, sua amizade, seu carinho, seu amor, seu companheirismo e sua presença ao meu lado nos momentos mais difíceis e também mais felizes. 
SUMÁRIO

AGRADECIMENTOS

RESUMO

ABSTRACT

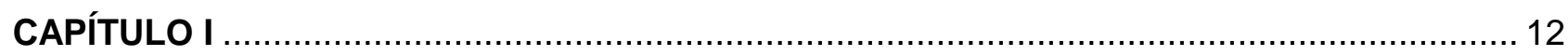

INTRODUÇÃO E FUNDAMENTAÇÃO TEÓRICA

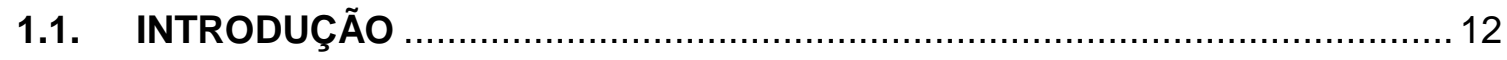

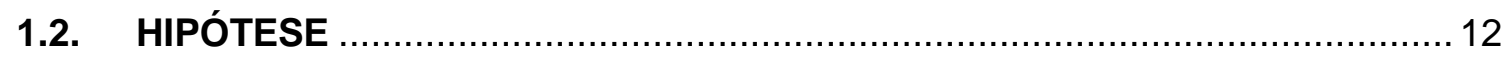

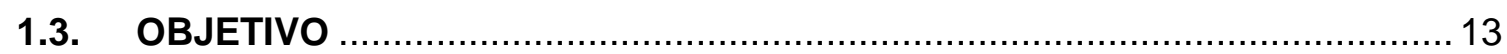

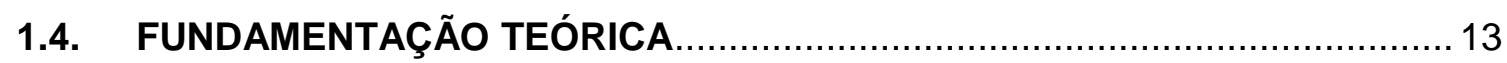

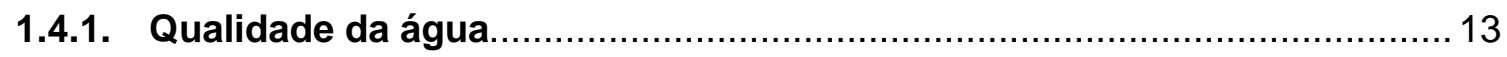

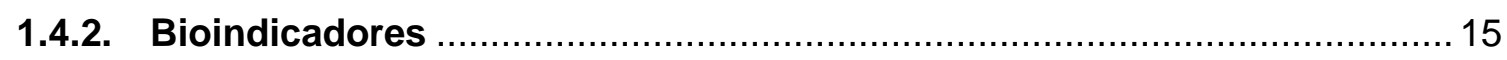

1.4.3. Modelos de avaliação da qualidade da água .......................................... 18

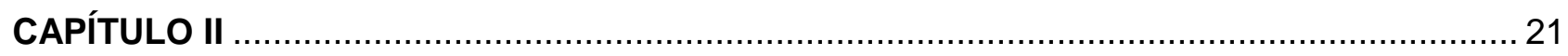

MATERIAL E MÉTODOS

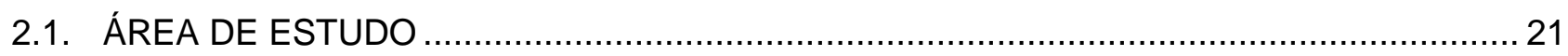

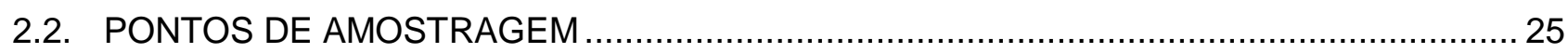

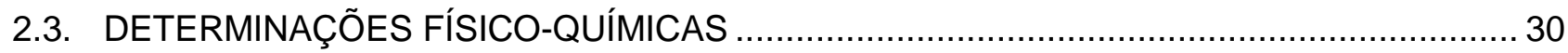

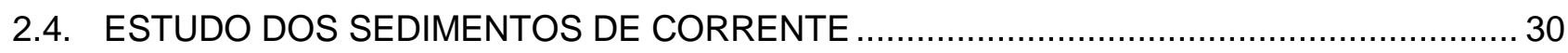

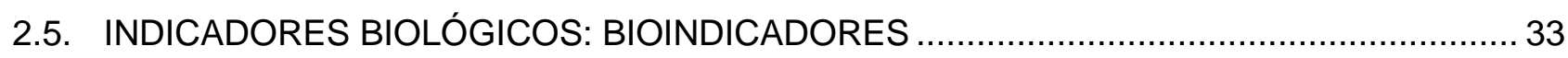

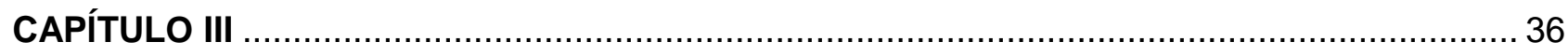

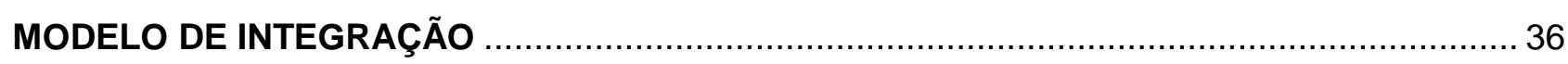

3.1. APLICAÇÃO DO MODELO

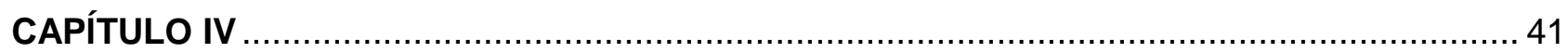

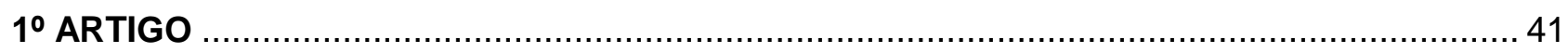

"QUALIDADE DA ÁGUA E CORRELAÇÃO DE PARÂMETROS FÍSICO-QUÍMICOS EM DRENAGENS URBANA E RURAL DE FORMOSA/GO"........................................................ 41

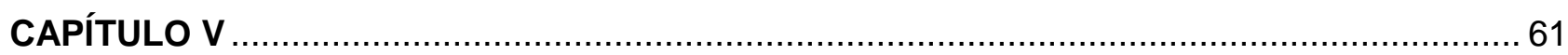

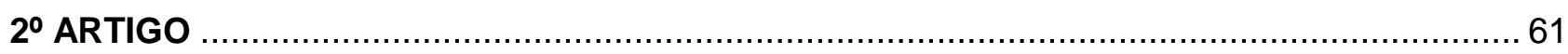

"ESTUDO DOS SEDIMENTOS DE CORRENTE EM DRENAGENS INSERIDAS NA ÁREA RURAL

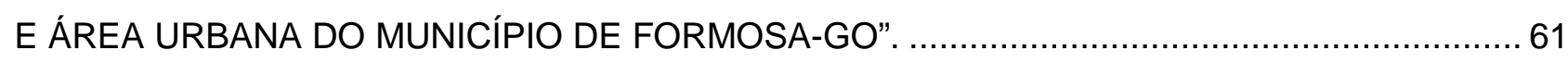

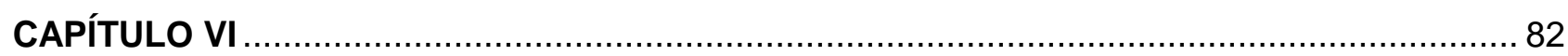

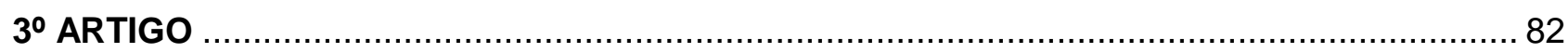

"ESTUDO DA QUALIDADE DA ÁGUA POR MEIO DE BIOINDICADORES BENTÔNICOS EM CÓRREGOS DA ÁREA RURAL E URBANA DO MUNICÍPIO DE FORMOSA/GO". ...................... 82

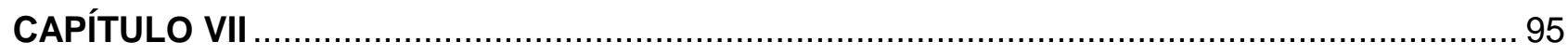

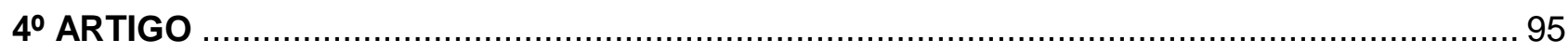


MODELO APLICADO NOS PERÍODOS CHUVOSO E SECO DE 2015 ................................ 118

8.1. DETERMINAÇÕES FÍSICO-QUÍMICAS .................................................... 118

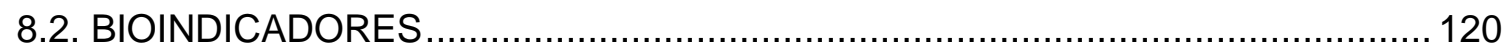

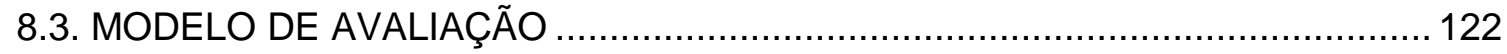

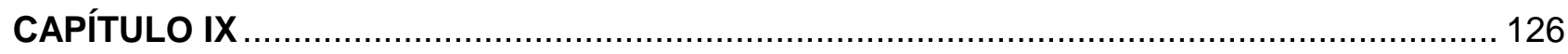

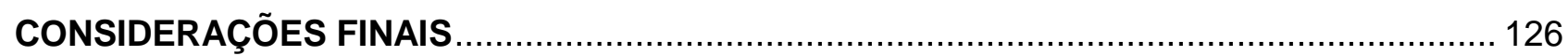

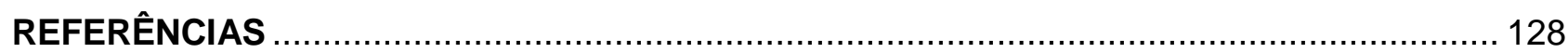

\section{LISTA DE FIGURAS}

\section{CAPÍTULO II}

Figura 1: Localização do município de Formosa-GO.

Figura 2: Espacialização dos pontos de amostragem córregos Bandeirinha e Josefa Gomes.

Figura 3: Córrego Bandeirinha PB1, cerca de 300 metros da nascente........................................27

Figura 4: Córrego Bandeirinha PB2, vista das margens.........................................................27

Figura 5: Córrego Bandeirinha PB3, margens protegidas dentro da fazenda Asa

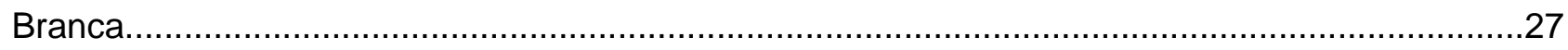

Figura 6: Coleta a montante da Barragem de Captação.........................................................27

Figura 7: Vista do PB5 dista cerca de 70 metros da GO 116 e aproximadamente 2,5 km do núcleo urbano do município.

Figura 8: PB6, próximo a GO 116, aumento na vazão do corpo de água, pela incidência de

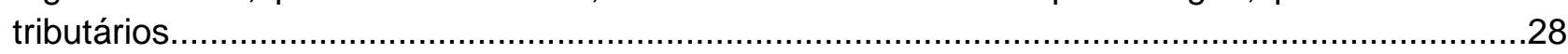

Figura 9: Vegetação predominante nas margens.........................................................28

Figura 10: PB8, aproximadamente 320 metros do exutório da bacia do Bandeirinha, desague no Rio

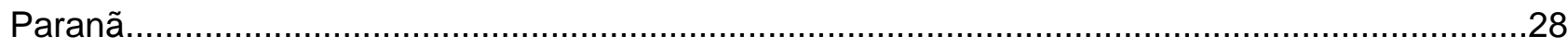

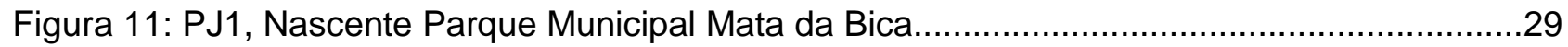

Figura 12: PJ2, final do trecho retificado encontro com a Avenida Califórnia...............................29

Figura 13: PJ3, detalhe da adutora de água da SANEAGO, próximo ao Residencial Califórnia, ocupação urbana recente cerca de 120 metros do ponto.......................................................29

Figura 14: Edificações residenciais, cerca de 10 metros de distância do córrego Josefa

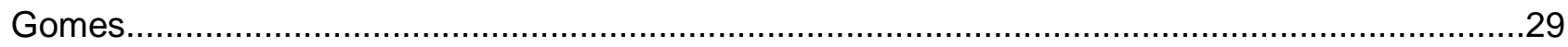

Figura 15: Especificações do amostrador de bentos tipo surber...................................................33

Figura 16: Coleta de bentos com a utilização do surber para amostragem..................................33

Figura 17: Detalhe do surber, utilizado nos pontos de coleta de água.........................................33

Figura 18: A1: Organismo intolerante, Ordem: Plecoptera, Família: Anacroneuria; A2: Organismo intolerante: Ordem Trichoptera, Família: Hydropsychidae; B: Organismo tolerante, Ordem: Odonata, 
Família: Aeshenidae; C: Organismo Resistente, Ordem: Díptera, Família: Psychodidae.

\section{CAPÍTULO III}

Figura 1: Intervalo para classificação final, integrando os métodos de análise. 39

Figura 2: Fluxograma lógico do modelo de pesos da evidência fundamenta nas respostas das determinações físico-químicas; estudo dos sedimentos e espécies bioindicadoras. 39

\section{CAPÍTULO IV}

Figura 1: Localização do município de Formosa-GO

Figura 2: Pontos de amostragem córrego Bandeirinha e Josefa Gomes, FormosaGO.......

Figura 3: Distribuição dos parâmetros físico-químicos do grupo A (Temperatura, Cor, Turbidez, pH, C.E, TSD, O.D e Alcalinidade), córrego Bandeirinha e Josefa Gomes, períodos de chuva e seca.

Figura 4: Distribuição dos parâmetros físico-químicos do grupo $\mathrm{B}\left(\mathrm{NH}_{3} ; \mathrm{Na}, \mathrm{K}, \mathrm{SO}_{4}{ }^{2}, \mathrm{PO}_{4}{ }^{3}, \mathrm{NO}_{3}{ }^{-1}\right.$, $\left.\mathrm{Cl}^{-}, \mathrm{F}^{-}\right)$, córrego Bandeirinha e Josefa Gomes, períodos de chuva e seca......

\section{CAPÍTULO V}

Figura 1: Localização do município de Formosa-GO...

Figura 2: Pontos de amostragem córrego Bandeirinha e Josefa Gomes, FormosaGO.

Figura 3: Caracterização granulométrica dos sedimentos nos córregos Josefa Gomes (PJ) e Bandeirinha (PB, distribuídos ao longo dos pontos de amostragem. .72

Figura 4: Difratograma dos pontos no córrego Josefa Gomes, Formosa-GO. .75

\section{CAPÍTULO VI}

Figura 1: Localização da área, pontos de amostragem nos córregos Bandeirinha e Josefa Gomes, Formosa-GO.

Figura 2: Percentagem de ocorrência das classes granulométricas dos sedimentos nos córregos Josefa Gomes e Bandeirinha, pontos de amostragem.

Figura 3: Análise de agrupamento (UPGMA) realizada a partir da matriz dos coeficientes de similaridade de Bray-Curtis, para os 12 pontos amostrados. Pontos córrego Bandeirinha (PB); Pontos córrego Josefa Gomes (PJ) .90

\section{CAPÍTULO VII}

Figure 1: Location of the area, stream sampling points Bandeirinha and Josefa Gomes, FormosaGO...... 99

Figure 2: Interval to the final classification, integrating the analysis methods .104 
Figure 3: Interaction between 3 methods of analysis using the model, during the rainy season and dry, resulting of Stream Bandeirinha $(a, b)$ and Josefa Gomes (c, d)....

\section{CAPÍTULO VIII}

Figura 1. Intervalo para classificação final, integrando os métodos de análise. 122

Figura 2. Interação entre os métodos de análise utilizados no modelo, períodos chuvoso e seco de 2015, resultados do córrego Bandeirinha (a, b) e Josefa Gomes (c, d) 124

\section{LISTA DE TABELAS E QUADROS CAPÍTULO II}

Quadro 1: Córregos Bandeirinha e Josefa Gomes, pontos de amostragem e referência de localização.

Quadro 2: Espécies bioindicadoras utilizadas como resistentes, tolerantes e intolerantes.

\section{CAPÍTULO III}

Quadro 1: Diagrama lógico da relação das evidências na aplicação do modelo

\section{CAPÍTULO IV}

Tabela 01: Córrego Bandeirinha e Josefa Gomes, pontos de amostragem e referência de localização.

Tabela 02: Parâmetros físico-químicos no período chuvoso e seco, córregos Bandeirinha e Josefa Gomes.

Tabela 3: Matriz de correlação de Spearman entre parâmetros físico-químicos, nas águas do córrego Bandeirinha, período chuvoso e seco. Apenas correlações com significância p < 0,05 .

Tabela 4: Matriz de correlação de Spearman entre parâmetros físico-químicos, nas águas do córrego Josefa Gomes, período chuvoso e seco. Apenas correlações com significância $p<$ 0,05 .

\section{CAPÍTULO V}

Quadro 1: Localização e descrição do uso do solo nos pontos de amostragem. 69

Quadro 2: Sólidos voláteis em percentagem (\%) para os córregos Bandeirinha e Josefa Gomes.

Quadro 03: Resultados da difratometria de raio-x nas amostras do Córrego Bandeirinha e Josefa Gomes.

Quadro 4: Elementos maiores e elementos-traço em amostras de sedimentos no córrego Bandeirinha e Josefa Gomes......

\section{CAPÍTULO VI}

Tabela 1: Índices de diversidade para os 12 pontos amostrados entre as drenagens dos córregos Bandeirinha (PB) e Josefa Gomes (PJ), Formosa-GO... 
Tabela 2: Densidades dos táxons amostrados nos córregos Bandeirinha (PB) e Josefa Gomes (PJ), classificados por seu grau de tolerância, segundo Callisto et al (2004). $C$ = período chuvoso; $S=$ período seco.

\section{CAPÍTULO VII}

Table 1: Logic Diagram of the evidence relation in applying the model 103

Table 02: Physicochemical parameters in the pluvial and dry periods. 104

Table 3: Spearman correlation matrix between the physical-chemical parameters in waters of the stream Bandeirinha, in the raining and dry time. Correlations that mean $p$ $<0,05$. 105

Table 4: Spearman Correlation Matrix between the physical-chemical parameters, in stream Jose Gomes waters in the raining and dry periods. The meaningful correlation with $p<$ 0,05 . 106

Table 05: Difrotometry results of X-rays in the samples of Stream Bandeirinha and Josefa Gomes. 108

Table 06: Major elements and traces in sediments of Stream Bandeirinha and Josefa Gomes. 108

Table 07: Taxons classifications concerning to the bioindication and tolerance of environments according to Callisto et al (2004). Stream Bandeirinha (PB) and Josefa Gomes (PJ) raining period (C) dry period (S).

Table 08: Model results to Stream Bandeirinha and Josefa Gomes in raining period

Table 09: Model results to Stream Bandeirinha and Josefa Gomes in the dry period

\section{CAPÍTULO VIII}

Tabela 01: Parâmetros físico-químicos córregos Bandeirinha e Josefa Gomes, períodos chuvoso e seco de 2015

Tabela 2: Matriz de correlação de Spearman entre parâmetros físico-químicos, nas águas do córrego Bandeirinha, período chuvoso e seco (2015). Apenas correlações com significância $p<$ 0,05 .

Tabela 3: Matriz de correlação de Spearman entre parâmetros físico-químicos, nas águas do córrego Josefa Gomes, período chuvoso e seco (2015). Apenas correlações com significância $p<$ 0,05 .

Tabela 4: Classificação dos Táxons quanto sua bioindicação a tolerância dos ambientes segundo Callisto et al. (2004). Córregos Bandeirinha e Josefa Gomes, períodos chuvoso e seco de 2015.

Quadro 4: Resultados do modelo para os córregos Bandeirinha e Josefa Gomes no período chuvoso (2015) 122

Quadro 5: Resultados do modelo para os córregos Bandeirinha e Josefa Gomes no período seco (2015) 
A obtenção de informações integradas a respeito de um corpo hídrico depende do estudo das interações que ocorrem entre os fatores do meio físico, biótico e antrópico na área avaliada. A dinâmica de interação entre estes fatores é o que determina a qualidade da água nas drenagens superficiais, as avaliações que focam em apenas um destes aspectos, apresentam incertezas nos resultados. Com o objetivo de melhorar a interpretação quanto à qualidade, propõe-se um modelo de integração fundamentado no peso da evidência entre os resultados das: determinações físicoquímicas; estudo dos sedimentos e utilização de bioindicadores. A interpretação dos resultados de cada método aplicado gerou uma linha de evidência quanto à qualidade da água, estas linhas de evidencias são integradas em uma classificação final das condições de cada ponto em: < 5 Processos Naturais; $\geq 5 \leq$ 7,5 Processos Naturais/Antrópicos; > 7,5 < 15 Processo predominante antrópico; $\geq 15$ Completamente Alterado. Como área representativa, optou-se pelos córregos Bandeirinha e Josefa Gomes localizados no município de Formosa-GO, este situa-se na microrregião do entorno de Brasília. O córrego Bandeirinha é o manancial utilizado pelo sistema de abastecimento de água do município, e está inserido em área predominantemente rural. O córrego Josefa Gomes está inserido no núcleo urbano do município. A escolha dos dois córregos deu-se pelo fato de estarem localizados em ambientes distintos, fato que proporcionou respostas características na aplicação do modelo. Foram espacializados da nascente ao exutório 8 pontos de amostragem no córrego Bandeirinha e 4 pontos no Josefa Gomes. O modelo aplicado foi validado pelas respostas individuais dos métodos, pela diferença entre ambiente urbano e rural e pelos períodos chuvoso e seco dos anos de 2013 e 2015. No córrego Bandeirinha os pontos PB1, PB2, PB3, mantiveram no valor de $<5$ indicando processos naturais, enquanto os pontos PB4, PB5, PB6, PB7 e PB8 apresentaram alteração no período chuvoso permanecendo no valor de < 6 indicando processos naturais/antrópicos. Todos os pontos do córrego Josefa Gomes situam-se no intervalo de $\geq 7,5 \leq 15$, indicando processos predominante antrópicos. No córrego Bandeirinha, a maior influência na pontuação final, durante o período chuvoso decorre da menor diversidade e número de táxons de organismos intolerantes e resistentes, no período seco mesmo com a concentração dos parâmetros físico-químicos, o maior número de táxons de organismos intolerantes tem maior influência na qualidade desta drenagem. Enquanto que no córrego Josefa Gomes tanto no período seco quanto chuvoso, os pontos permaneceram no intervalo de $\geq 7,5 \leq 15$, assinalando alterações de origem antrópica. A integração dos métodos auxiliou na identificação da qualidade da água com um número menor de pontos de amostragem, redução de custos e tempo de análise. O modelo mostrou-se satisfatório para aplicação em ambientes rurais ou urbanos, uma vez que sua aplicação auxilia na identificação de áreas críticas para intervenção e pode ser utilizado na implementação de medidas de conservação, proteção e políticas de gestão ambiental. 
Obtaining integrated information on a body of water depends on the study of the interactions that occur between the factors of physical, biotic and anthropic environment in the area evaluated. The dynamic interaction between these factors is what determines the quality of water in surface drainage, evaluations that focus on just one of these aspects, present uncertainties in the results. In order to improve the interpretation as to the quality, we propose a model of integration based on the weight of evidence from the results of: physicochemical analysis; study of sediments and use of bioindicators. Interpretation of the results of each method used generated a line of evidence about the water quality, these lines of evidence are integrated into a final classification of the conditions at each location: $<5$ Natural processes; $\geq 5 \leq 7,5$ Natural processes/anthropic; $>7,5<15$ Processes predominate anthropic; $\geq 15$ Completely changed. As a representative area, it was decided by Bandeirinha and Josefa Gomes streams located in the city of Formosa GO, it is located in the region around Brasilia. The Bandeirinha stream is the source used by the municipal water supply system, and is situated in a predominantly rural area. The Josefa Gomes stream is inserted in the urban core of the city. The choice of two streams gave up because they are located in different environments, a fact that gave answers in the model application characteristics. They were tight from source to outfall 8 sampling points in Bandeirinha stream and 4 points in Josefa Gomes. The applied model was validated by the individual responses of the methods, the difference between urban and rural environment and the rainy and dry seasons of the years 2013 and 2015. In the stream Bandeirinha points PB1, PB2, PB3, kept in the range $<5$ indicating natural processes while the points PB4, PB5, PB6, PB7 and PB8 have changes in the rainy season remain in the range $<6$ indicating natural/anthropic processes. All stream Josefa Gomes points lie in the range of $\geq 15 \leq 7,5$ indicating predominant anthropic processes. The stream Bandeirinha, the greatest influence on the final score during the rainy season due to the lower diversity and number of taxa intolerant and resistant organisms during the dry season even with the concentration of physicochemical parameters, the highest number of taxa intolerant organisms It has greater influence on the quality of this drainage. While the stream Josefa Gomes both as rainy dry season, the points remained in the range of $\geq 7,5$ $\leq 15$, indicating changes of anthropogenic origin. The integration methods helped water quality identification with a smaller number of sampling points, reducing costs and analysis time. The model proved to be suitable for application in rural or urban environments, since its application helps to identify the critical areas of intervention and can be used in the implementation of conservation measures, protection and policies for environmental management. 


\section{CAPÍTULO I}

\section{INTRODUÇÃO E FUNDAMENTAÇÃO TEÓRICA}

\subsection{INTRODUÇÃO}

As alterações na qualidade da água nas drenagens superficiais podem ter causas naturais, relacionadas às características geológicas, pedológicas e geomorfológicas da região, assim como origem antrópica pelo lançamento de matéria e energia. Os estudos destas alterações na qualidade da água estão relacionados à compreensão da dinâmica de interação entre os fatores do meio físico, biótico e antrópico. Essas interações estão vinculadas a uma escala temporal, refletindo um comportamento dinâmico, intrínseco a cada ambiente.

Para a avaliação da qualidade da água, pode-se utilizar diversos métodos, entre os quais determinações físico-químicas, estudos dos sedimentos de corrente e utilização de bioindicadores. As avaliações de qualidade de água, utilizando apenas um dos métodos, apresentam incertezas quanto aos seus resultados, pois a dinâmica de interação não é contemplada nestas avaliações. Torna-se necessário, portanto, um modelo para integrar e correlacionar os métodos, proporcionando melhor interpretação dos resultados.

A modelagem é utilizada para integrar o conhecimento em determinado campo, e aplicase aos dados a partir de um local específico, ela pode ser usada para predizer estados futuros do sistema ou respostas às mudanças na interação com as características geológicas, climáticas, biológicas e antrópicas.

O modelo de integração proposto fundamentou-se no peso da evidência, a partir das respostas ou linhas de evidências obtidas na aplicação de métodos de avaliação da qualidade: determinação de parâmetros físico-químicos, estudos dos sedimentos de corrente e utilização de bioindicadores. Este modelo, que é uma forma de interpretar os resultados para permitir a comparação entre os pontos de amostragem, utiliza valores numéricos na interpretação dos resultados, atribuindo pesos e critérios de indexação.

Para aplicação do modelo optou-se pelos córregos Bandeirinha e Josefa Gomes, localizados no município de Formosa-GO, Brasil. O córrego Bandeirinha está inserido em área rural e o córrego Josefa Gomes no núcleo urbano. A escolha dos córregos deu-se pelo fato de estarem localizados em ambientes distintos dentro da mesma região. O modelo aplicado foi validado pelas respostas individuais dos métodos, pela diferença entre ambiente urbano e rural e pelos períodos chuvoso e seco de 2013 e 2015.

\subsection{HIPÓTESE}

A inter-relação entre linhas de evidências que correspondem aos resultados de diferentes métodos: determinação físico-química, estudos de sedimentos de corrente e utilização de 
bioindicadores proporciona melhor interpretação, redução de custos e tempo na avaliação da qualidade da água em drenagens superficiais.

\subsection{OBJETIVO}

Desenvolver e integrar diferentes linhas de evidências de estudos da qualidade da água em drenagens superficiais e proporcionar melhor avaliação dos resultados. Para tanto são elementos que contemplam o tema:

- Determinar parâmetros Físico-químicos de qualidade da água no córrego Bandeirinha e córrego Josefa Gomes;

- Realizar o estudo dos sedimentos de corrente com determinações mineralógica, granulométrica e de sólidos voláteis.

- Analisar a qualidade da água com a utilização da comunidade bentônica como bioindicador;

- Comparar os resultados entre o córrego Bandeirinha, inserido em ambiente predominantemente rural, e o córrego Josefa Gomes, inserido no núcleo urbano do município de Formosa-GO.

- Desenvolver um modelo de integração fundamentado no peso da evidência para correlacionar as diferentes linhas de evidências quanto à qualidade da água.

\subsection{FUNDAMENTAÇÃO TEÓRICA}

\subsubsection{Qualidade da água}

A qualidade da água disponível nos recursos hídricos é determinada pelas propriedades físicas, químicas e biológicas, a interação entre estas propriedades, confere qualidade de acordo com a variação quantitativa e qualitativa dos elementos constituintes. As alterações nestas propriedades podem ter origem antrópica ou natural.

Os gestores estabelecem dispositivos legais, que contém os valores máximos e mínimos permitidos dos elementos ou características, que podem estar presentes na água. No âmbito da legislação brasileira, os parâmetros físico-químicos de qualidade de água possuem suas referências quantitativas nos Valores Máximos Permitidos - V.M.P, determinados pela resolução CONAMA 357/05. A legislação federal determina os V.M.P para os parâmetros de qualidade de água, contudo não é suficiente para distinguir um processo de alteração de origem antrópica ou natural, quando consideradas as diferenças morfoclimáticas, geológicas, pedológicas e socioeconômicas de cada região.

Conforme Carmo et al (2005), as atividades antrópicas que comprometem a qualidade da água estão relacionadas ao uso não controlado de insumos agrícolas e ao lançamento de efluentes industriais e domésticos. A distribuição de elementos químicos depende não somente das 
concentrações, mas também das reações físico-químicas nos ambienteis, diretamente influenciadas pelas condições ambientais, intemperismo natural e ações antrópicas.

Cyril e Weng (2010) destacaram que o exponencial crescimento das áreas urbanas e atividades agrícolas, implicam nas mudanças do uso e cobertura do solo, para atender ao crescimento populacional e alteraram significativamente a qualidade da água de superfície. Estes autores realizaram o estudo, demostrando que o nível de concentração de poluentes de fontes difusas nas águas de superfície dentro de uma bacia, depende muito das relações entre a época e a área que contribui para o escoamento superficial.

Poudel et al (2013) ressaltaram que a decomposição de materiais orgânicos nas drenagens resulta na adição de nitrogênio, fósforo, e outros elementos na água, além da poluição difusa de substâncias dissolvidas, tais como cloreto $\left(\mathrm{Cl}^{-}\right)$, sulfato $\left(\mathrm{SO}_{4}{ }^{2-}\right)$, e carbonatos $\left(\mathrm{CO}_{3}{ }^{2-}\right)$, que também alteram a qualidade das drenagens superficiais, proveniente da aplicação de fertilizantes, calcário, intemperismo das rochas, defensivos agrícolas, ou a partir de escoamento urbano.

Ainda conforme Poudel et al (2013), devido à interação entre os parâmetros é possível explicar a variabilidade na qualidade da água de superfície utilizando alguns grupos de parâmetros. Em seus estudos, os autores realizaram a análise da qualidade da água utilizando 13 parâmetros físico-químicos $\left(\mathrm{DBO}_{5}\right.$; Totais de Sólidos Suspensos; Nitrato; Nitrogênio Total; Fósforo Total; Fósforo Reativo Solúvel; Temperatura; Condutividade Elétrica; Totais de Sólidos Dissolvidos; pH; Turbidez; Oxigênio Dissolvido; Nitrogênio Total Kjeldahl) e interpretaram os resultados com técnicas de análise estatística não paramétricas. A aplicação das análises estatísticas e a interação dos parâmetros, proporcionou uma melhor interpretação quanto às alterações na qualidade da água na drenagem avaliada.

$\mathrm{Na}$ realização da avaliação da qualidade da água é fundamental considerar os períodos seco e chuvoso da área em questão. Zhang et al (2013) realizaram a comparação dos impactos da vazão do rio sobre a qualidade das águas superficiais do Rio Xiangjiang, na China, utilizando 12 parâmetros de qualidade da água de superfície em 31 pontos de amostragens, de janeiro de 1998 a dezembro de 2008. Ao longo da drenagem principal constatou-se que concentrações significativamente maiores de nitrogênio total, nitrogênio amoniacal, fósforo total, e $\mathrm{DBO}_{5}$ ocorreram durante os períodos de seca da região, o que implica a necessidade de um maior controle dos órgãos ambientais nesta época.

Para melhor interpretação das relações entre o meio físico e a qualidade da água, além das determinações físico-químicas utilizadas em diversos estudos, pode-se realizar também a amostragem dos sedimentos de corrente. As amostras de sedimentos informam possíveis anomalias a montante do local da coleta, pois representam a interação entre todos os processos que ocorrem no ecossistema aquático, e auxiliam para elucidar quanto à poluição ambiental atribuída aos metais ou substâncias orgânicas (Boaventura e Moreira, 2003).

Maia et al (2005) realizaram o estudo mineralógico dos sedimentos de fundo no lago Paranoá, em Brasília, utilizando técnicas de difratometria de raios-X. Os autores constataram que 
muitas informações sobre a geologia e a composição química de uma bacia de drenagem são registradas nos sedimentos de corrente.

Mulholland et al (2012) utilizaram a determinação mineralógica e geoquímica para identificação e separação das influências de ordem antrópica ou geológica na composição dos sedimentos de corrente. Os autores identificaram os depósitos minerais e atividades de mineração como fontes de metais no sedimento para determinar a distribuição e acúmulo, aplicando técnicas de difratometria de raios- $X$ associadas à análise das amostras, usando Espectrometria de Emissão Óptica com fonte de Plasma Indutivamente Acoplado (ICP/OES) e Espectrofotometria de Absorção Atômica (AAS).

Tanto em amostras de sedimento quanto em amostras de água, é possível identificar a presença de metais, seja de origem natural ou antrópica. Conforme Santos et al (2012), diversos estudos em drenagens superficiais indicam como possível fonte dos elementos: $\mathrm{Cu}, \mathrm{Fe}, \mathrm{Ni}, \mathrm{Al}, \mathrm{Cr}$, Mn, Zn e Cd, o uso e ocupação do solo, seja em área urbana ou rural. A utilização de insumos nas atividades agrícolas auxilia no aumento da produtividade em relação à área cultivada, contudo geram impactos ambientais no solo e nas drenagens superficiais, além da possiblidade de intoxicação das comunidades próximas por meio da ingestão progressiva destes produtos. Em áreas urbanas, temos a utilização de combustíveis, lubrificantes, produtos de limpeza e atividades industriais como fonte antrópica destes elementos.

Carmo et al (2003) aplicaram técnicas de ICP/OES e AAS, além de análise granulométrica e determinação do material volátil, para identificar alterações geoquímicas nos sedimentos de corrente do rio Descoberto no DF, demonstraram os efeitos de atividades antrópicas na região e a contribuição no processo de alteração geoquímica das águas na Bacia do Rio Descoberto.

\subsubsection{Bioindicadores}

As determinações físico-químicas e estudo dos sedimentos de corrente contemplam a geoquímica, auxiliam na identificação das alterações na qualidade da água nas drenagens superficiais. Contudo, outros métodos podem ser utilizados para realizar estudos preliminares, complementares ou monitoramentos, que busquem a dinâmica de interação entre os fatores do meio físico, antrópico e biótico. A avaliação da qualidade da água, nas drenagens superficiais pelas determinações físico-químicas e sedimentos, pode ser associada à utilização de bioindicadores.

De acordo com Ribeiro e Uieda (2005), ainda que as análises físico-químicas demonstrem o estado da água, o ideal é a associação desses métodos com métodos biológicos, permitindo uma caracterização mais completa, abrangendo os aspectos biológicos e a interação entre o meio físico, muitas vezes necessária para o manejo adequado dos recursos hídricos.

A bioindicação consiste na observação e acompanhamento das respostas apresentadas por uma espécie ou grupo de espécies indicadoras durante um intervalo de tempo, visando obter informações sobre a condição do ambiente e mudanças nas comunidades biológicas (Mugnai et al., 2010). As comunidades biológicas com a presença de poluentes na água sofrem alterações em 
densidade e riqueza, com isso são capazes de indicar o efeito das ações antrópicas ou naturais no ambiente, o que permite uma avaliação biológica eficiente dos fatores atuantes.

A bioindicação usa alguns organismos que compõem determinado ambiente para caracterizá-lo e retratar o seu estado em relação às condições de existência de organismos biológicos e de alterações no meio. Os objetivos são conservar e conhecer melhor o comportamento das comunidades ecológicas quando submetidas a fatores estressantes, como a supressão da vegetação na perda de habitats, poluição e outras (Chalar, 1994).

Para Callisto e Moreno (2006), espécie indicadora é aquela que apresenta respostas a variações ambientais e, quando presente em determinada área, revela um conjunto de condições particulares daquele ambiente. A essência da bioindicação são as relações entre os seres vivos e os fatores ambientais. Assim, rápidas mudanças do ambiente provocadas pelo homem causam flutuações populacionais nos organismos. Cada espécie possui um padrão de variação característico: algumas são mais tolerantes, outras menos.

A Agência de Proteção Ambiental dos Estados Unidos (Environmental Protection Agency - EPA) recomenda a utilização de critérios biológicos que utilizam a condição de um organismo ou conjunto de organismos, para descrever a integridade ecológica de uma área impactada, pouco impactada, ou áreas de referência, para complementar as informações sobre qualidade da água, tradicionalmente baseadas em parâmetros físico-químicos.

Callisto et al (2004) apontam que a sensibilidade às alterações do meio ambiente é o que determina a escolha dos bioindicadores; os mais utilizados são aqueles capazes de diferenciar entre oscilações naturais e alterações antrópicas, podendo indicar a presença e a dimensão de um determinado impacto ou anomalia no ambiente, sendo que várias espécies podem ser utilizadas como bioindicadores.

Os indicadores biológicos têm sido considerados eficientes para medir a qualidade da água com baixos custos. Milesi et al (2008) afirmam que os macroinvertebrados constituem um dos melhores bioindicadores de qualidade das águas nos ambientes lóticos, pois possuem características sésseis, ciclo de vida relativamente longo e são de fácil visualização.

Callisto et al (2004) destacam que as amostragens de bentos são relativamente fáceis e baratas, pois estes são sedentários e variavelmente sensíveis às condições ambientais. Portanto podem integrar e acumular condições em um ambiente, oferecendo um nível de diagnóstico, considerando a natureza dos efeitos observados.

Os macroinvertebrados referem-se à fauna de invertebrados que fica retida em uma malha de $0,5 \mathrm{~mm}$, sendo ela constituída por diversos táxons, tais como Arthropoda, Mollusca, Annelida, Nematoda e Platyhelminthes, dentre outros. A maioria dessas espécies estão associadas aos habitats de fundo das drenagens superficiais e lagos, fixos ou não a um substrato, sendo denominada de comunidade bentônica. (Maenpaa et al., 2003).

A utilização de bioindicadores para o monitoramento ambiental, com ênfase em insetos aquáticos é empregada em outros países, com métodos bem definidos e comunidades 
bioindicadoras conhecidas. Os macroinvertebrados bentônicos têm sido amplamente utilizados como bioindicadores de qualidade de água, por apresentarem as seguintes características: ciclos de vida longo, (os macroinvertebrados bentônicos podem viver entre semanas, meses e mesmo mais de 1 ano); em geral são organismos grandes (maiores que 125 ou $250 \mu \mathrm{m}$ ), sésseis ou de pouca mobilidade, portanto mais fáceis de serem amostrados, com custos relativamente baixos; grande diversidade taxonômica e de identificação relativamente fácil (ao nível de família e alguns gêneros); são organismos sensíveis a diferentes concentrações de poluentes no meio (Callisto e Moreno, 2006).

A utilização dos bioindicadores pode também ser mais direcionada a um tipo de poluição, Belmejo e Martos (2008) utilizaram bioindicadores sensíveis à poluição hídrica de derivados de petróleo em condições tropicais, impacto diretamente relacionado a drenagens localizadas em ambientes urbanos.

Milesi et al (2008), realizaram o estudo dos efeitos dos metais Cobre e Zinco em comunidades de macroinvertebrados bentônicos, estes íons metálicos estão presentes em fertilizantes e pesticidas além de resíduos orgânicos provenientes de áreas urbanas e, portanto, sua correlação com os bioindicadores pode ser utilizada na identificação de impactos e na análise da qualidade da água em drenagens urbanas ou rurais.

Colpo et al (2009), utilizando os macroinvertebrados bentônicos como indicadores do impacto ambiental promovido pelos efluentes de áreas orizícolas e de origem urbana/industrial, concluíram que os efluentes produzidos pelas cidades e indústrias, são mais agressivos aos ambientes aquáticos que os efluentes drenados de uma lavoura manejada de acordo com as recomendações técnicas para a cultura.

Estudos mais recentes, como os de Yokoyama (2012), destacam a importância dos bioindicadores na avaliação da qualidade da água e seu comportamento, como a flutuação da riqueza de táxons em resposta à variação da precipitação entre os períodos seco e chuvoso. Este efeito deve ser considerado ao realizar os estudos e monitoramento da qualidade da água.

A legislação brasileira, mais especificamente a Resolução CONAMA 357/2005, classifica as drenagens superficiais por meio de padrões e valores máximo e mínimo permitidos para os parâmetros físico-químicos, não considerando as informações da dinâmica de interação dos organismos bioindicadores de qualidade de água. Contudo, os órgãos ambientais já solicitam dos empreendimentos relatórios de qualidade de água em programas de monitoramento que contenham, além dos parâmetros físico-químicos de qualidade, indicação biológica para drenagens superficiais. É previsível que a legislação deva-se atualizar, direcionando uma metodologia que contemple a inter-relação da qualidade da água entre os parâmetros físico-químicos e os bioindicadores. 


\subsubsection{Modelos de avaliação da qualidade da água}

A preocupação com a qualidade da água tem se tornado uma necessidade permanente. Conforme Rodriguez et al (2014), nos últimos anos, fatores políticos e técnicos como modelagem da qualidade da água, monitoramento de nutrientes e sedimentos, concentrações de pesticidas e poluentes nos córregos e rios, influenciaram mudanças nas políticas ambientais.

Le et al (2014) ressaltam que a eficiência para a tomada de decisão quanto à gestão da qualidade da água é fundamental para redução de custos financeiros e ambientais. Os autores propõem em seu estudo um modelo de qualidade de água aglomerado, com sensibilidade e análise de incerteza, e um domínio de gerenciamento, incluindo a estimativa de perda e valor da análise da informação e consequentemente, indo além dos valores máximos e mínimos determinados pelos órgãos ambientais para os parâmetros de qualidade da água.

Reichert e Vanrolleghem (2001) alegam que a modelagem da qualidade da água auxilia na integração dos resultados. Estes modelos possuem diversos parâmetros e levantam a questão de quantos parâmetros podem ser montados em um determinado contexto, e como encontrar subconjuntos de parâmetros identificáveis dada a disposição experimental. Os modelos podem ser usados para predizer estados futuros do sistema ou de suas respostas às mudanças imediatas das condições atuais.

Os autores acima citados, realizaram a identificação e a análise de incerteza no Modelo de Qualidade da Água em Rios, o RWQM1. Os autores consideraram que a redução da incerteza na aplicação do modelo pode ser realizada através da melhoria de projetos experimentais, em condições mais dinâmicas ou com adoção de medidas como a quantificação da biomassa bentônica. Também, ambientes controlados em laboratório podem fornecer informação adicional para apoiar a calibração do RWQM1.

Budka et al (2010) estudaram a modelagem preditiva da poluição da água usando dados de bioindicadores para águas marinhas e concluíram que os bioindicadores podem ser usados com sucesso na discriminação de diferentes níveis de toxicidade aquática, mesmo em pequena quantidade de dados disponíveis. A escolha de bioindicadores influenciam o desempenho dos modelos construídos e está também fortemente ligada com o custo monetário. Os autores destacaram que, para algumas aplicações, desenvolver modelos baratos, mas não muito precisos seria suficiente, enquanto que para algum outro propósito a precisão do modelo irá ser o fator mais importante, independente do custo.

Meier et al (2013) propuseram um sistema integrado de avaliação de sedimentos usando análises químicas dos sedimentos, bioavaliação e bioindicação com peixes, em área contaminada por hidrocarbonetos em um córrego de Midwestern EUA. Com a aplicação destas análises, conseguiram determinar se a área contaminada deve ser incluída na lista de prioridades nacional para mais ações de remediação. 
Outros estudos como o de Benedetti et al (2011) buscaram a integração entre diferentes abordagens para proporcionar uma caracterização multidisciplinar, que combine estudos por meio de pesos na classificação de sedimentos poluídos. Tiveram como objetivo confirmar a sensibilidade e a importância de uma avaliação multidisciplinar da qualidade dos sedimentos. Utilizam dados sobre a química dos sedimentos, bioacumulação, variação de biomarcadores e respostas de bioensaios, sendo agregados dentro de um modelo de Peso da Evidência (PE), que resume índices de perigo (IP), em Linhas de Evidência (LE) agrupados em módulos específicos, antes de sua integração global.

Segundo os autores acima a LE1: Química dos Sedimentos, baseia inicialmente no cálculo para cada poluente da Relação de Referência (RR), ou seja, a razão entre a concentração medida em sedimentos e o que é indicado por diretrizes de qualidade de sedimentos, no estudo, foram utilizados os níveis das classes A, B, C do Protocolo de Veneza. Os resultados sobre a bioacumulação de substâncias químicas nos tecidos expostos de enguias foram elaborados dentro da LE2: Biodisponibilidade. Para cada parâmetro, o RR foi calculado como o aumento de concentração em comparação com amostras de controle, corrigido para a tipologia dos poluentes.

Na LE3 Benedetti et al (2011) utilizaram Biomarcadores, baseando-se na possibilidade de escolher entre uma ampla bateria de respostas, atribuindo para cada resposta um peso e um limite para alterações de relevância biológica. Para cada biomarcador, a variação medida foi comparada com o efeito, em seguida corrigido para o peso da resposta. Também na LE4, um limiar de peso específico, foi dado a vários bioensaios. A LE4 derivada da bateria de bioensaios, foi obtida pela soma dos efeitos ponderados, ou seja, as variações de medição para vários ensaios em comparação com limiares relativos, corrigidos pelo peso.

$\mathrm{Na}$ interação das LEs Benedetti et al (2011), utilizou os resultados das LEs individuais elaboradas com a abordagem de ponderação de prova, integrou e deu um diferente peso para várias linhas de evidência. Os valores foram multiplicados por 1,0 (LE1 e LE3); e 1,2 (para LE2 e LE4). A atribuição de uma diferente ponderação para LEs foi baseado em suas diferentes relevâncias ecológicas, e na capacidade dos conjuntos de dados de revelar diretamente efeitos negativos.

Benedetti et al (2011), concluíram na aplicação do modelo que embora a escolha de pesos é de alguma forma arbitrária, integrando múltiplas LEs, este procedimento apresentou resultados mais consistentes para dados sobre a biodisponibilidade dos produtos químicos em comparação com aqueles que avaliam a presença de tais compostos somente nos sedimentos. Da mesma forma, os dados que refletem os efeitos biológicos em um organismo tiveram uma melhor interpretação.

Benedetti et al (2011) destacam que a aplicação de metodologias do peso da evidência tem sido amplamente utilizada dentro dos procedimentos de avaliação de risco ambiental e, embora a escolha de linhas de evidências, ou seja, diferentes estudos e integração de dados diferem 
dependendo dos objetivos ou locais especificidades, a abordagem multidisciplinar fornecida auxilia em uma melhor interpretação.

Semenzin et al (2008), desenvolveram modelo baseado em Multicritérios de Análise de Decisão, para integrar índices de biodisponibilidade, ecologia e ecotoxicologia, usando estes como linhas de evidência. Estes índices visam quantificar o comprometimento do ecossistema terrestre. O modelo elaborado integrou a informação, obtida pelas respostas dos índices em linhas de evidencias. Especificamente, o modelo inclui dois procedimentos: as análises das linhas de evidência e o procedimento para o cálculo integrado.

Linkov et al (2009) destacam que as abordagens de interação elaboradas para sintetizar os diferentes estudos ou linhas de evidências podem ser tanto qualitativas quanto quantitativas para uma avaliação integrada de qualidade, deficiência ou risco. Os mais simples métodos qualitativos são interpretações de resultados diferentes, enquanto abordagens quantitativas são baseadas em mais estrutura matemática e elaborações estatísticas, proporcionando índices para cada linha de evidência e para a sua integração global.

Apesar de não ser um procedimento padronizado, o desenvolvimento de modelos para a comparação e agregação de dados heterogêneos por métodos quantitativos, pode contar com a atribuição de pesos, critérios de indexação, classificação dos pontos, comparação de condições de referência e funções de normalização (Dagnino et al, 2008; Linkov et al., 2009; Semenzin et al., 2008; Suter e Cormier, 2011; Benedetti et al2011).

Conforme Beck (1999), estimar todos os parâmetros do modelo e integrar todos os dados é utópico. Em vez disso, um subconjunto de parâmetros deve ser selecionado, pois com bons dados, pode-se obter um modelo bem calibrado para uma determinada aplicação em um sistema real.

A avaliação da qualidade da água pode ser realizada por meio das respostas de análises físico-químicas, estudos dos sedimentos de corrente e bioindicação. A integração destas linhas de evidências ou respostas em um modelo, complementa a dinâmica de interação dos fatores do meio físico e biótico que determinam a qualidade da água em drenagens superficiais. 


\section{MATERIAL E MÉTODOS}

\section{1. ÁREA DE ESTUDO}

As áreas definidas para o desenvolvimento da pesquisa são o córrego Bandeirinha e o córrego Josefa Gomes, ambos no município de Formosa-GO. O córrego Bandeirinha está inserido em ambiente rural e o córrego Josefa Gomes em ambiente urbano. A escolha das duas drenagens deu-se por possuírem características distintas, porém localizadas na mesma região, o que permite a comparação da aplicação dos métodos em ambos ambientes.

O município de Formosa-GO está situado na microrregião do entorno de Brasília, possui área de 5.806,89 km², e altitude em torno de 916 metros, seus limites são com os municípios de Água Fria de Goiás, Cabeceiras, Flores de Goiás, Planaltina, São João D’Aliança, Vila Boa, Distrito Federal e com o Estado de Minas Gerais. Formosa situa-se a 280 km da capital do Estado, Goiânia e, a $70 \mathrm{~km}$ de Brasília, embora a divisa do estado com o Distrito Federal fique apenas $5 \mathrm{~km}$ do núcleo urbano. Dados do IBGE (2012) apontam para o município uma população total de 100.085 habitantes, sendo distribuída em 92.023 habitantes em zona urbana e 8.062 em zona rural, o que representa $91,95 \%$ e 8,05\% respectivamente. A agropecuária é atividade estruturante na economia, principalmente a pecuária de corte e leite, que demandam maior uso do solo no município pela utilização de área para formação de pastagens. Assim como em outros municípios do entorno, a forma e a velocidade do processo de ocupação urbana em Formosa, impulsionadas pela construção de Brasília, refletem-se fortemente sobre os recursos naturais e meio social. Na figura 1 é apresentada a localização do município.

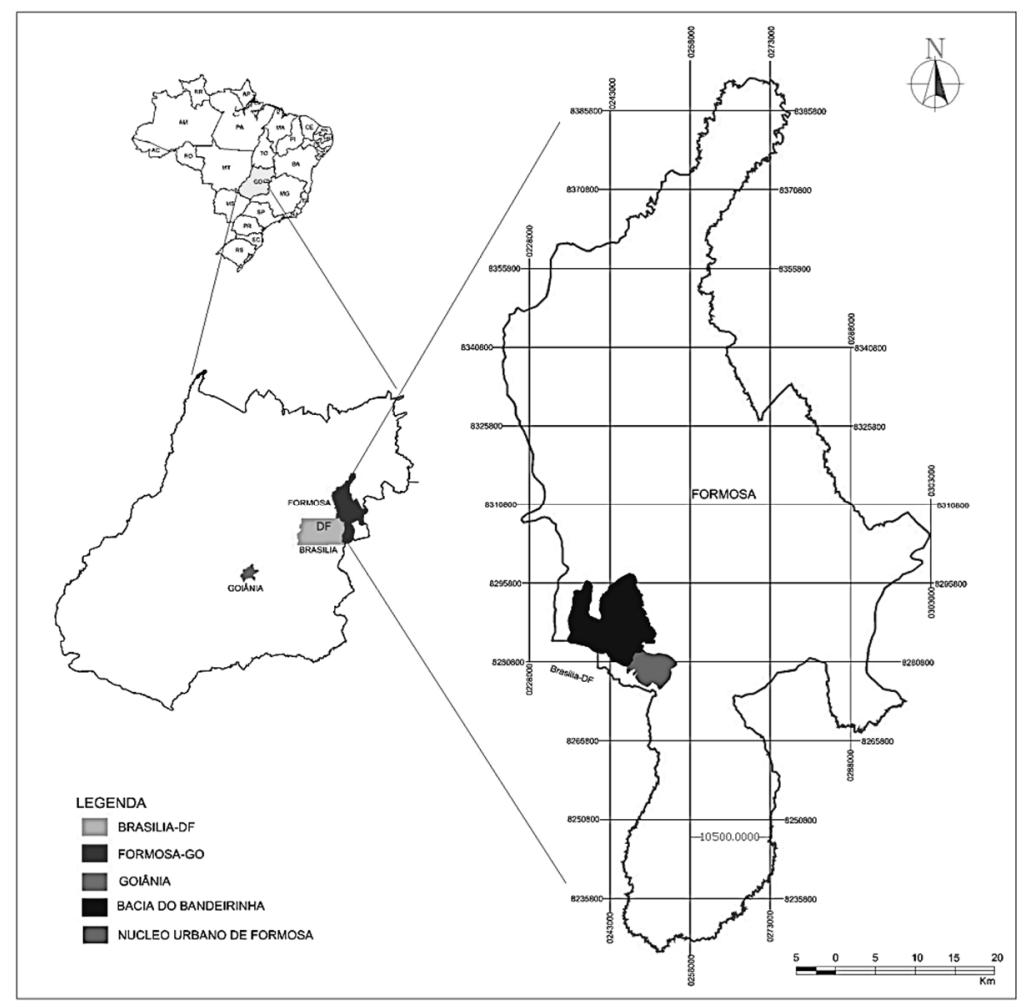

Figura 1. Localização do município de Formosa-GO Fonte: IBGE 2012, Organização Final, Pimenta 2014. 
A região possui clima, segundo a classificação de Köppen tipo Aw, caracterizado por duas estações bem definidas: uma seca, que corresponde ao outono e inverno, e a outra úmida com chuvas torrenciais, correspondendo ao período de primavera e verão. O período de inverno caracteriza-se por estabilidade climática e reduzida precipitação. Os dados utilizados no município de Formosa são os da série histórica (normais climatológicas, 1961-1990) obtidos pela estação meteorológica convencional do INMET (1555' latitude sul e 47³4' longitude oeste, altitude 935 metros), e ilustram bem as transformações climáticas na região.

A distribuição pluviométrica é padrão típico da região Centro-Oeste do Brasil e do domínio morfoclimático dos Cerrados, com precipitação média anual na ordem de $1.485,30 \mathrm{~mm}$, concentrando-se principalmente nos meses de outubro a abril. Nos meses de junho e julho as precipitações são praticamente ausentes. A temperatura média anual é em torno de $21,5^{\circ} \mathrm{C}$, com uma média menor próxima de $16,8^{\circ} \mathrm{C}$, nos meses de junho e julho a temperatura mínima atinge $13^{\circ} \mathrm{C}$ e corresponde ao inverno na região. No verão, a temperatura eleva-se aos $27,7 \stackrel{\circ}{ } \mathrm{C}$. A temperatura média tende a um leve aumento de janeiro a março, e decai até os meses de junho e julho, nos quais se registram os menores valores médios. No mês de agosto tende a elevarem-se, atingindo seu ápice nos meses de setembro, outubro e novembro, quando há um novo declínio da temperatura.

Os principais estudos geológicos e geomorfológicos que enfocam a região são os trabalhos realizados por Mauro et al (1982), Faria (1995), Guimarães (1997), Campos e Cunha (1999), Latrubesse et al (2005).

A carta geológica do Serviço Geológico do Brasil CPRM (2004) SD 23, folha Brasília, apresenta para a região do município de Formosa, a ocorrência de rochas do Proterozóico, representado pelo Grupo Paranoá de idade mesoproterozóica e Grupo Bambuí, Subgrupo Paraopeba de idade neoproterozóica, coberturas Detrito-Lateríticas do Terciário-Quaternário e Aluviões recentes nas margens dos cursos de água.

Os dados sobre litoestratigrafia, sistemas deposicionais e geotectônica do Grupo Paranoá são apresentados por Faria (1995) que o caracterizam como uma sequência deposicional em ambiente marinho, subdividida em doze litofácies com status de formação e agrupadas em quatro megaciclos sedimentares. Os dois primeiros transgressivos, um intermediário, regressivo, com várias oscilações e o último novamente transgressivo.

Faria (1995) denominou os megaciclos, da base para o topo, em: Unidade Conglomerática Quartzítica Inferior constituída por paraconglomerado, metarritmitos e quartzitos; Unidade SílticoArdosiana; constituída pelas unidades síltica e ardosiana; Unidade Rítmica Quartzítica Intermediária; composta pela unidade rítmica e quartzítica intermediárias e Unidade Rítmica PelitoCarbonatada, constituída por um conjunto interestratificado de siltitos, argilitos, silexitos e quartzitos, contendo lentes de calcário. 
Conforme Guimarães (1997) na região de Formosa-Bezerra-Cabeceiras, o Grupo Paranoá é exposto no centro de grandes anticlinais inversos de flancos falhados, podendo estar recoberto pelos diamictitos glaciais da Formação Jequitaí ou diretamente pelos carbonatos do Grupo Bambuí.

Por meio de estudos sedimentológicos e químicos das rochas dos grupos Paranoá e Bambuí, Guimarães (1997) aponta que as rochas de ambas as unidades se originaram em contextos tectônicos distintos e que os sedimentos são provenientes de rochas-fontes diferentes. As rochas do Grupo Paranoá são arenitos e pelitos, formados por sedimentos cratônicos, depositados lentamente sobre uma bacia tectonicamente estável. As rochas terrígenas do Grupo Bambuí são mineralógica e texturalmente imaturas, tendo os sedimentos se acumulado em uma bacia sobre influência de processos colisionais.

O Grupo Paranoá é formado pelo empilhamento de quartzitos e pelitos, com participação menor de arcóseos, quartzitos glauconíticos e carbonatos, enquanto as rochas terrígenas do Grupo Bambuí são ricas em micas detríticas e argilominerais. Micas (moscovita e biotita) são alteradas diageneticamente para cloritas e ilitas, ou têm composição fengítica. A composição e textura de cloritas ferrosas indicam substituição de minerais máficos ou representam o produto da evolução diagenética de esmectitas trioctaédricas. (GUIMARÃES, 1997).

O município de Formosa e a área de estudo do córrego Bandeirinha e córrego Josefa Gomes estão situados na Região dos Planaltos de Goiás-Minas. Chaves et al (2014) destacam que a Região dos Planaltos de Goiás-Minas é formada pelas Chapadas do Distrito Federal, caracterizase por modelados constituídos principalmente de uma superfície de aplainamento degradada e retocada pela dissecação incipiente, produzida pelos Rios São Bartolomeu e Preto. A sudeste da cidade de Formosa, os topos tabulares do planalto são mantidos por couraças ferruginosas constituídas por fragmentos de rocha.

No município é evidente a presença dos Sistemas Cársticos, estes associados a rochas do Grupo Bambuí. Conforme Almeida et al (2006) neste compartimento geomorfológico, a recarga e circulação hídrica dos aquíferos apresentam um padrão característico, com alta velocidade de fluxo, grandes distâncias entre zonas de recarga e descarga, alta vulnerabilidade à contaminação e forte sensibilidade às variações.

Faria (1995) descreve que a Cobertura Detrito-Laterítica presente na região, corresponde a uma superfície desenvolvida a partir de um processo de aplainamento e laterização de toda uma região que engloba o centro-oeste brasileiro. São caracterizadas por latossolos vermelhos amarronzados, estrutura indefinida e textura areno-argilosa. Mostra o desenvolvimento de perfis lateríticos maturos e imaturos, onde ocorrem níveis de linhas de pedras, com predominância de fragmentos angulosos de quartzo, geralmente dispostos na porção superior dos mesmos.

Os aluviões são caracterizados por sedimentos inconsolidados, dominantemente arenosos, representados por areias, com níveis de cascalhos e lentes de material silto-argiloso. Os latossolos não chegam a ocupar metade da área, parte dela é coberta por solos litólicos e 
cambissolos, além de terra roxa estruturada similar, classificados como Neossoloslitólicos, Cambissolos e Nitossolos respectivamente (GUIMARÃES, 1997).

O córrego Bandeirinha tem suas nascentes localizadas na Fazenda Bandeirinha dentro do município de Formosa, sob as coordenadas Longitude UTM $0235931.00 \mathrm{~m}$ E; Latitude UTM $8285262.00 \mathrm{~m} \mathrm{~S}$, em altitudes médias de 1.130 metros, com um percurso de 41,96 km direção Norte, desaguando no Rio Paranã, em altitude aproximada de 600 metros, próximo a Serra Laranjeira, seu desnível aproximado é de 530 metros. É o principal manancial atualmente aproveitado pelo sistema de abastecimento de água no município.

A drenagem principal da bacia do córrego Bandeirinha dista do seu meandro mais próximo cerca de $2 \mathrm{~km}$ do núcleo urbano do município de Formosa, porém recebe contribuições por alguns dos seus tributários, localizados em área urbana na saída norte do município. O córrego Bandeirinha está inserido em zona rural, onde predomina atividades agropastoris em toda a extensão do curso de água.

Há áreas de vegetação remanescente de cerrado ligados a reserva legal de propriedades particulares, e matas estacional, de galeria, e ciliar acompanhando os cursos de água do córrego Bandeirinha, sendo estas mais exuberantes nos topos de morros. Também existem áreas de cultivos implantados, constituído pela soja, milho e capineiras, além das pastagens, em maior escala.

A bacia hidrográfica que forma a cabeceira do Rio Preto está inserida dentro da área urbana de Formosa. Na área urbana este córrego tem o nome de Josefa Gomes, e deságua na Lagoa Feia. Assim como outros municípios brasileiros a ocupação urbana em torno desta drenagem ocorreu de forma desordenada, gerando impactos ambientais nesta área. O córrego Josefa Gomes, está completamente inserido em ambiente urbano, tem percurso de 7,5 km direção sudoeste, sua nascente localiza-se no parque municipal Mata da Bica sob as coordenadas Longitude UTM 0249481 m E Latitude UTM 8278785 m S, com elevação de 945 metros desaguando na Lagoa Feia em elevação de 873 metros, possui desnível aproximado de 72 metros, o que contribui para a velocidade do escoamento.

A área da nascente no Parque Municipal Ecológico Mata da Bica possui várias surgências de água que se unem ao longo da área do parque formando a Lagoa da Mata da Bica, esta por consequência alimenta a vazão do Córrego Josefa Gomes. Parte do percurso do córrego é retificada, neste trecho o córrego também é conhecido como córrego Beira-rio. A obra de retificação foi iniciada em 1983 e seguiu até 1988. O trecho retificado inicia na lagoa da Mata da Bica e se estende aproximadamente 1,5 km de percurso, possui 2,5 metros de largura. Após a retificação o córrego Josefa Gomes percorre aproximadamente $6 \mathrm{~km}$ e deságua na Lagoa Feia. Em seguida a Lagoa Feia o córrego é denominado de Rio Preto percorrendo os Estados de Goiás, Distrito Federal e Minas. O Rio Preto é um dos principais tributários do rio Paracatu, no Estado de Minas Gerais, e este é um importante afluente do Rio São Francisco. 


\subsection{PONTOS DE AMOSTRAGEM}

Para a realização do estudo foram selecionados 8 pontos no córrego Bandeirinha e 4 pontos no córrego Josefa Gomes. A seleção dos pontos de amostragem ocorreu pela análise dos seguintes critérios: atividades antrópicas ao longo da drenagem, incidência de tributários na rede de drenagem, possíveis fontes de poluição identificadas e acessibilidade dos pontos selecionados.

As coletas ocorreram nos meses de janeiro e setembro de 2013, de acordo com o período chuvoso e seco da região. Os pontos de coleta são apresentados no Quadro 1, espacializados conforme a Figura 2.

Quadro 1. Córregos Bandeirinha e Josefa Gomes, pontos de amostragem e referência de localização.

\begin{tabular}{|cccc|}
\hline Pontos & Coordenadas U.T.M & Elevação $(\mathbf{m})$ & Referência de Localização \\
\hline \multicolumn{4}{c|}{ Córrego Bandeirinha } \\
\hline PB1 & $236493,72-8285621,08$ & 1076,79 & Fazenda Asa Branca \\
PB2 & $238214,31-8290682,55$ & 1039,06 & Córrego Cachoeira Alta \\
PB3 & $239970,07-8287121,16$ & 999,64 & Fazenda Asa Branca \\
PB4 & $242870,84-8284033,05$ & 982,34 & Captação Água (SANEAGO) \\
PB5 & $248426,21-8284776,50$ & 800,89 & Rodovia GO 116 \\
PB6 & $248773,91-8287121,41$ & 708,85 & Rodovia GO 116 \\
PB7 & $246708,56-8291243,96$ & 661,98 & Fazenda Jenipapo \\
PB8 & $246891,00-8297253,00$ & 605,75 & Fazenda Santo Estevão \\
\hline \multicolumn{5}{r}{ Córrego Josefa Gomes } & \\
\hline PJ1 & $249564,69-8278950,81$ & 926,83 & Nascente Paq. Mun. Mata da Bica. \\
PJ2 & $250132,09-8280902,66$ & 902,07 & Final Trecho Retificado, Av. Califórnia. \\
PJ3 & $251728,59-8281177,27$ & 888,13 & Adutora Água Trat. Rua Ametista \\
PJ4 & $252937,47-8280043,56$ & 879,96 & Rua 24, Ponte da Av. B \\
\hline
\end{tabular}




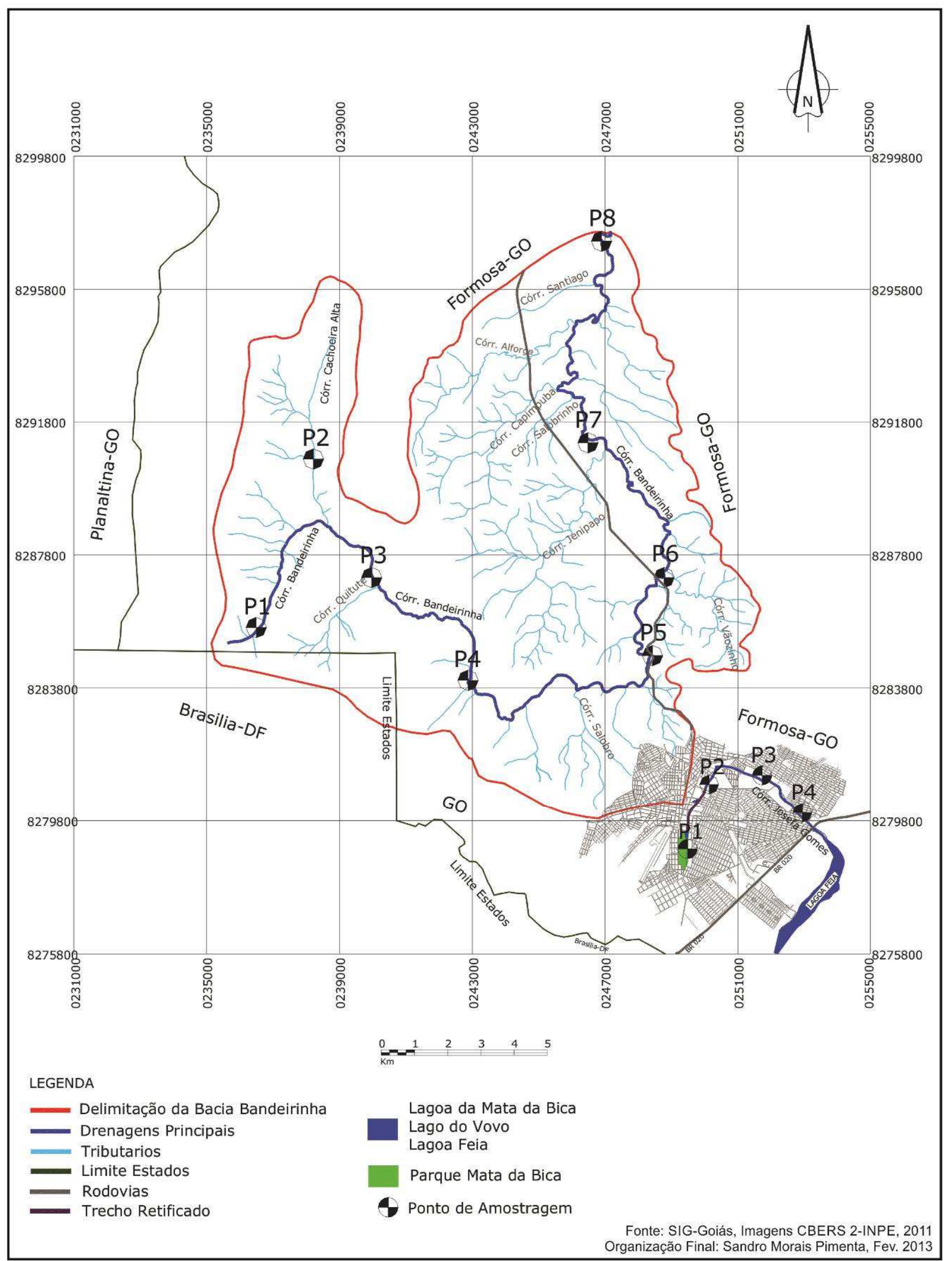

Figura 2. Espacialização dos pontos de amostragem córregos Bandeirinha e Josefa Gomes. 
Os 8 pontos de coleta no córrego Bandeirinha seguem da nascente, montante para desague jusante no Rio Paranã. Seu percurso é predominante na área rural, sendo assim caracterizados: Ponto PB1 próximo à área de nascente, na Fazenda Asa Branca e recebe influência das atividades agropastoris. O ponto PB2 é um dos tributários do córrego Bandeirinha, o córrego Cachoeira Alta, próximo cerca de 800 metros de uma produção de hortaliças.

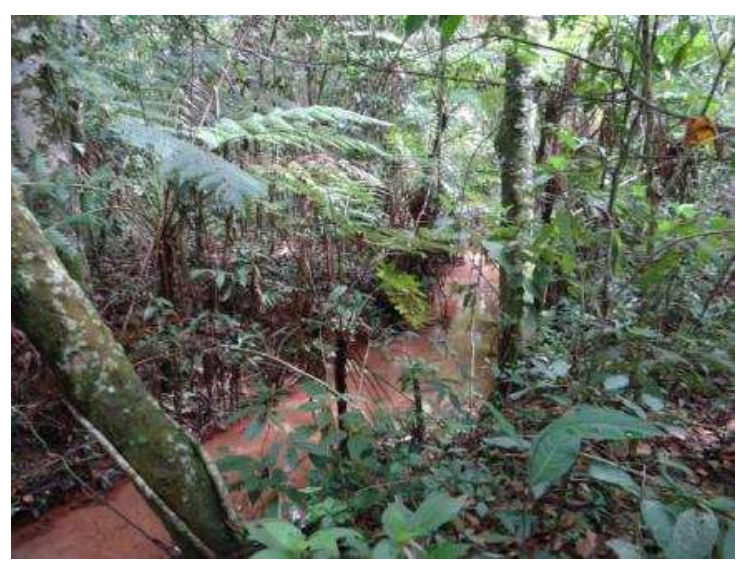

Figura 3. Córrego Bandeirinha PB1, cerca de 300 metros da nascente.

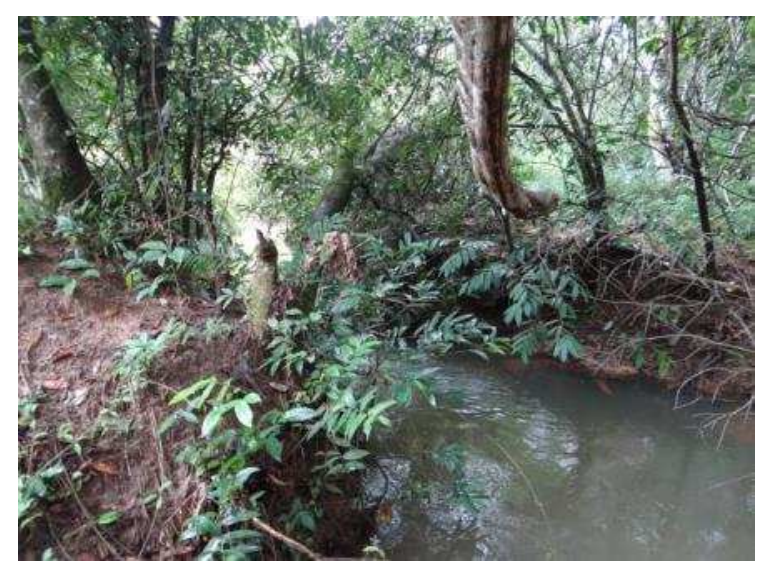

Figura 4. Córrego Cachoeira Alta PB2, vista das margens.

O ponto PB3 está em área rural, também localizada na Fazenda Asa Branca, contudo esta área é utilizada para a pecuária extensiva, e mantém as margens protegidas, onde foi observada uma faixa de aproximadamente 30 metros de vegetação ciliar. O ponto PB4 está na área de captação de água do córrego Bandeirinha, utilizada pela concessionária de Saneamento de Goiás - SANEAGO, para o abastecimento do município, localizada na Fazenda Bandeirinha. Esta área é utilizada para a implantação de uma nova barragem. O solo do local está, em parte, desprovido de vegetação nativa, com presença de remanescentes de pastagens e em parte, ocupado pela atual estação de bombeamento de água.

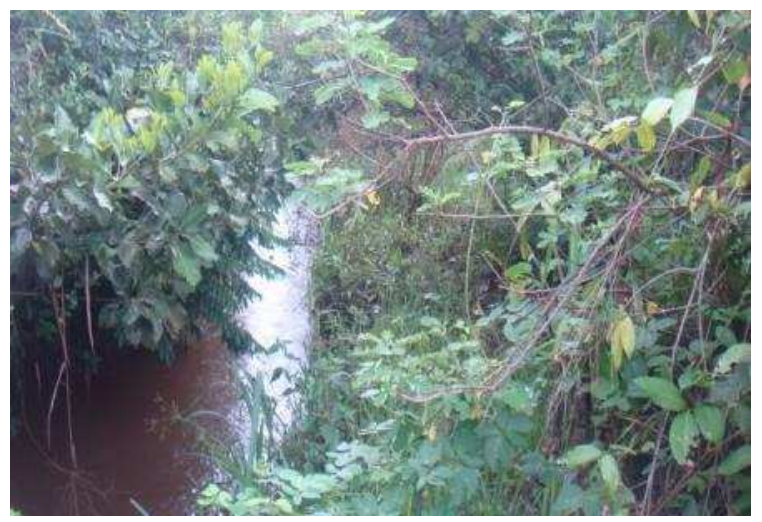

Figura 5. Córrego Bandeirinha PB3, margens protegidas dentro da fazenda Asa Branca.

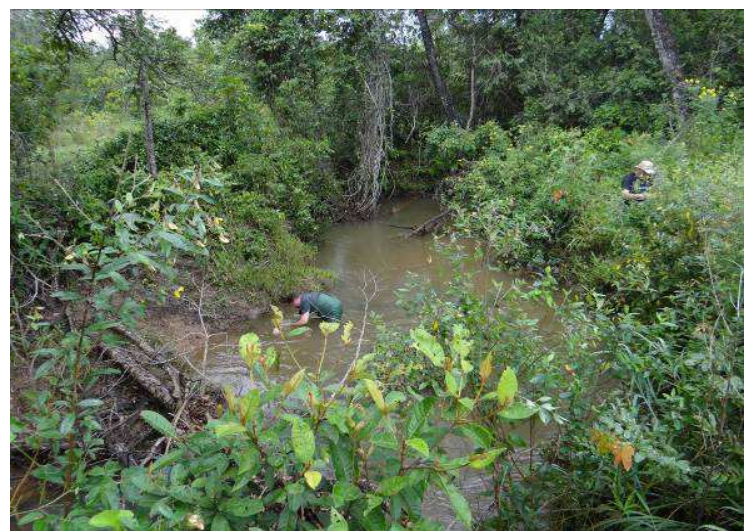

Figura 6. PB4, coleta a montante da Barragem de Captação 
Os pontos PB5 e PB6 estão localizados a jusante do núcleo urbano do município, próximos à rodovia GO 116, e recebem a influência deste. A montante destes dois pontos foi constatada, a presença de um depósito de resíduos sólidos urbanos e da construção civil, na saída da rodovia G0116, direção Norte, limite urbano do município próximo ao córrego Salobro, tributário do Bandeirinha.

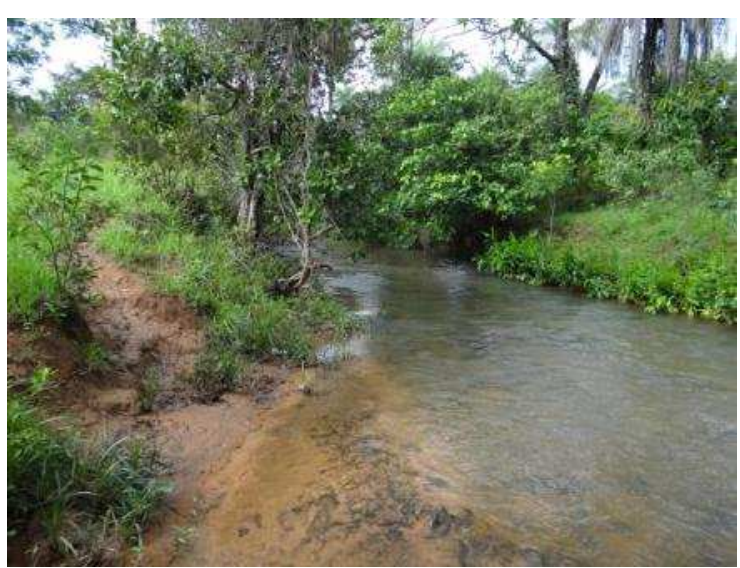

Figura 7. Vista do PB5 dista cerca de 70 metros da GO 116 e aproximadamente 2,5 km do núcleo urbano do município.

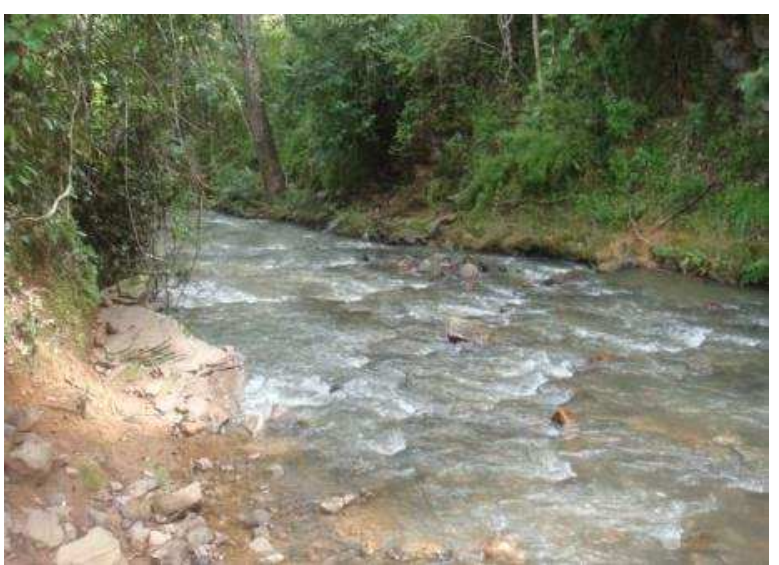

Figura 8. PB6, próximo a GO 116, aumento na vazão do corpo de água, pela incidência de tributários.

O ponto PB7 está localizado na Fazenda Jenipapo, logo após o deságue do córrego Jenipapo, tributário da bacia do Bandeirinha; suas margens e área de proteção permanente encontram-se preservadas. O ponto PB8 está localizado na Fazenda Santo Estevão, próximo ao exutório da bacia do Bandeirinha no Rio Paranã, que também possui as margens protegidas com a presença de vegetação e densa área de proteção permanente.

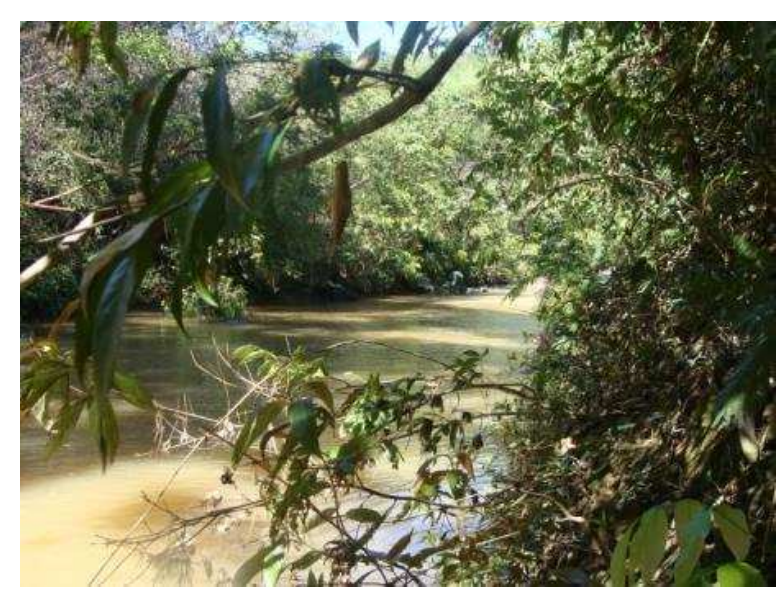

Figura 9. PB7, vegetação predominante nas margens.

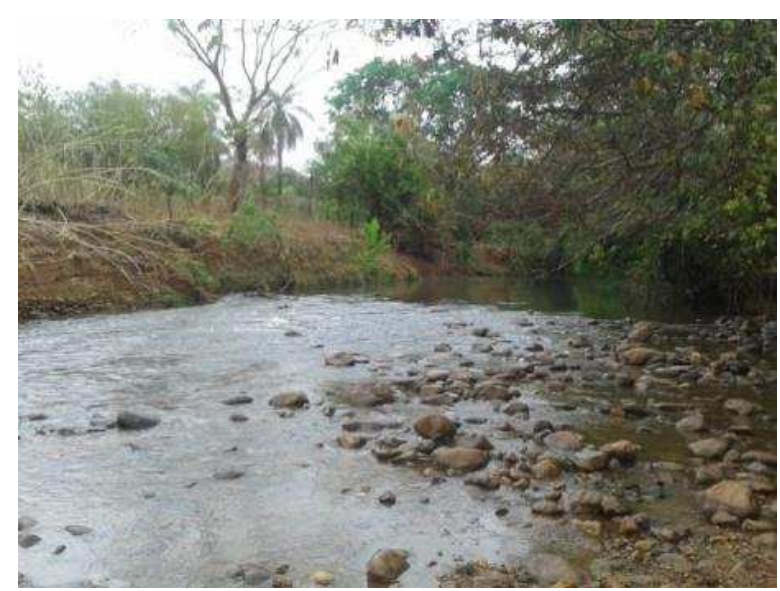

Figura 10. PB8, aproximadamente 320 metros do exutório da bacia do Bandeirinha, desague no Rio Paranã. 
Os 4 pontos de amostragem no córrego Josefa Gomes seguem da nascente no parque municipal Mata da Bica até seu deságue, na Lagoa Feia. O ponto PJ1 foi amostrado próximo à nascente, dentro do parque municipal Mata da Bica. O Ponto PJ2 está localizado logo após o término do trecho de 1,5 km retificado do Josefa Gomes, no encontro da Avenida Ivone Sadd com a Avenida Califórnia. Sua margem apresenta resíduos sólidos, odor característico de efluente doméstico, além do lançamento de drenagem pluvial oriunda das Avenidas Ivone Sadd e Califórnia, sua margem esquerda está em processo de assoreamento.

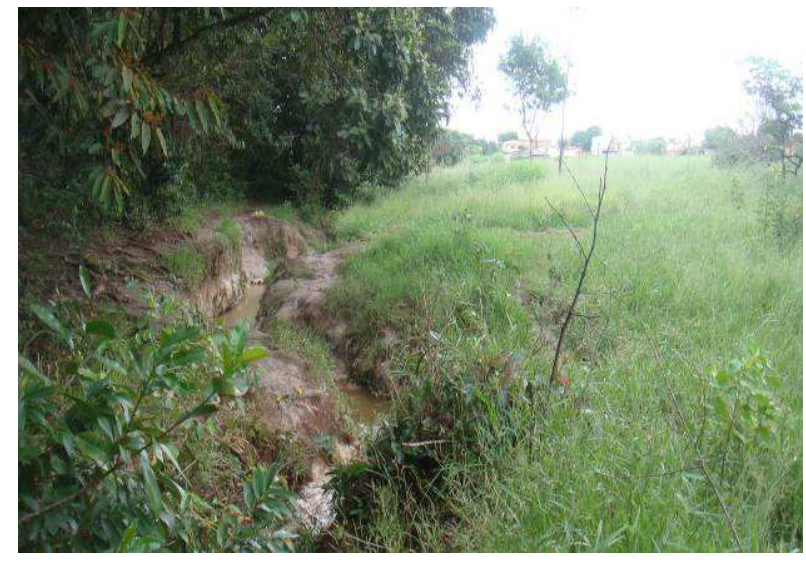

Figura 11. PJ1, Nascente Parque Municipal Mata da Bica.

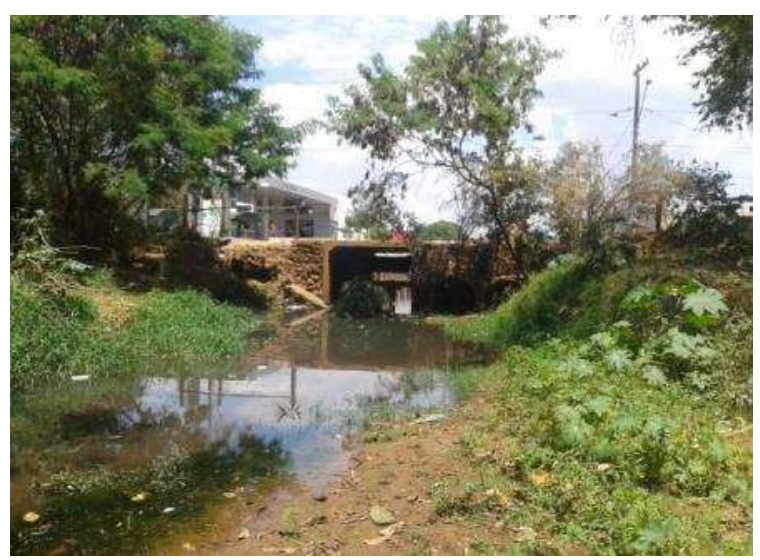

Figura 12. PJ2, final do trecho retificado encontro com a Avenida Califórnia.

O ponto PJ3 está localizado próximo ao conjunto de casas unifamiliares, recém-construídas e ocupadas, a cerca de 120 metros de distância, observa-se, nas margens, a presença de resíduos sólidos. O ponto PJ4 está localizado próximo à Avenida $\mathrm{B}$, área com grande adensamento populacional e dista cerca de 10 metros das residências na Rua 06. Neste ponto também se encontra resíduos sólidos nas suas margens, além de odor característico de efluente doméstico, sua margem esquerda está em processo de assoreamento. Este ponto dista aproximadamente 800 metros do deságue do córrego Josefa Gomes na Lagoa Feia.

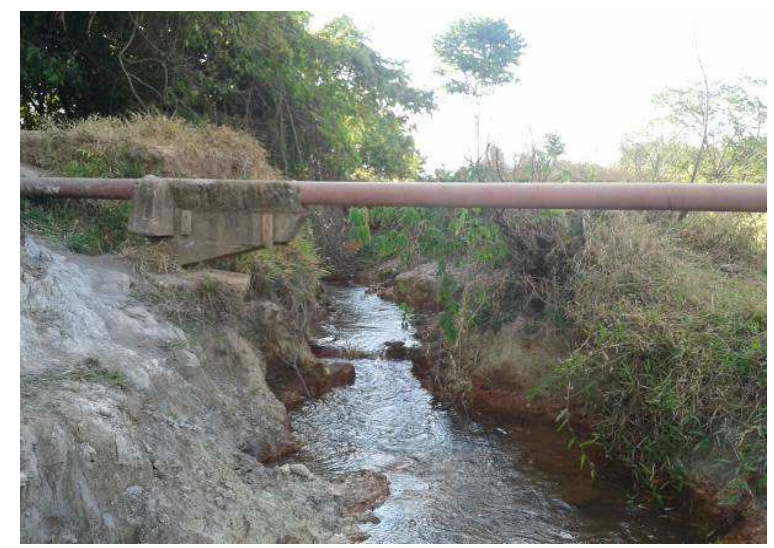

Figura 13. PJ3, detalhe da adutora de água da SANEAGO, próximo ao Residencial Califórnia, ocupação urbana recente cerca de 120 metros do ponto.

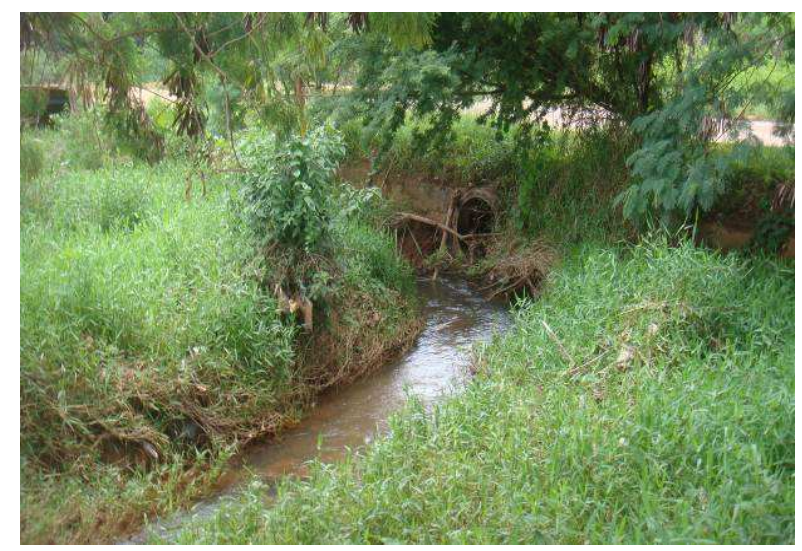

Figura 14. Edificações residenciais, cerca de 10 metros de distância do córrego Josefa Gomes. 


\subsection{DETERMINAÇÕES FÍSICO-QUÍMICAS}

Nos 12 pontos de amostragem foram realizadas em campo as determinações de $\mathrm{pH}$, Temperatura, Condutividade Elétrica e Totais de Sólidos Dissolvidos, utilizando um multiparâmetro portátil (modelo Hach, série Sension 378) e Oxigênio Dissolvido, por meio de Oxímetro Micropocessado portátil (modelo OMC-900). Para a coleta das amostras de água foram utilizados frascos de polietileno de $1 \mathrm{~L}$ previamente identificados, lavados com ácido nítrico $10 \% \mathrm{v} / \mathrm{v}$ e com água obtida por sistema de purificação Milliq (resistividade de $18,2 \mathrm{M} \Omega \mathrm{cm}^{-1}$ a $25^{\circ} \mathrm{C}$ ). No momento da coleta, foram ambientados com a mesma água da amostra e acondicionadas sob refrigeração em caixas térmicas até a chegada nos Laboratório de Geoquímica da UnB e Laboratórios do Instituto Federal de Goiás. Turbidez, Cor e $\mathrm{NH}_{3}$ foram determinados por técnicas colorimétricas com leitura em espectrofotômetro (modelo Hach DR 2000).

As amostras de água coletadas foram divididas em duas frações de $50 \mathrm{~mL}$ filtradas para dois frascos de centrífuga de $50 \mathrm{~mL}$ utilizando membranas em ésteres de celulose com poro de $0,45 \mu \mathrm{m}$ Milipore. Uma das frações foi acidificada com ácido nítrico suprapur Merck até $\mathrm{pH}<2$ para determinação de metais. A outra fração foi reservada para determinação dos ânions.

A determinação de $\mathrm{Na}$ e $\mathrm{K}$ foi realizada utilizando um Espectrofotômetro de Absorção Atômica - EAA, (modelo Perkin Elmer, Analyst 200), com fonte de excitação de chama de aracetileno. As determinações de Fe e Al, foram realizadas por Espectrometria de Emissão Óptica com fonte de Plasma Indutivamente Acoplado - ICP/OES (modelo Spectro, Spectroflame-Fvmo3), utilizando nebulizador Meinhard.

Os ânions: $\mathrm{F}^{-}, \mathrm{Cl}^{-}, \mathrm{NO}_{3}{ }^{-}, \mathrm{PO}_{4}{ }^{3-}$ e $\mathrm{SO}_{4}{ }^{2-}$ foram determinados por Cromatógrafo lônico IC com condutividade suprimida (modelo Dionex, ICS90). A alcalinidade foi determinada por método titulométrico com $\mathrm{H}_{2} \mathrm{SO}_{4}$ a $0,02 \mathrm{~N}$, padronizado com $\mathrm{NaOH} 0,05 \mathrm{~N}$, utilizando um titulador automático (modelo Schott, Titroline easy).

Os dados obtidos com as determinações físico-químicas foram tratados com a correlação de Spearman (R) entre os resultados, procedimento utilizado por Carmo et al (2005), Poudel et al (2013) e Zhang et al (2013). Esse é um método não paramétrico, usado nos casos em que os dados se apresentam dispersos, com alguns pontos da amostra bem distantes dos demais e quando esses não pertencem a uma escala de medida padrão, porém, possuem uma ordenação.

\subsection{ESTUDO DOS SEDIMENTOS DE CORRENTE}

Nos 12 pontos de amostragem de sedimentos foram avaliados: o fracionamento granulométrico, aferição dos sólidos voláteis, determinação de elementos maiores e traços e a análise da composição mineral por difratometria de Raios-X. Todos os procedimentos foram realizados nos Laboratórios de Geoquímica e de Raios-X do Instituto de Geociências da UnB, nos Laboratórios de Saneamento e Geotecnia do Instituto Federal de Goiás e no Laboratório da Campo: Centro de Tecnologia Agrícola e Ambiental Ltda, logo após a recepção das amostras. 
Os procedimentos de amostragem seguiram os trabalhos de Boaventura e Moreira (2003), Santo et al (2012), Mulholland et al (2012), foram coletadas amostras de sedimentos, aproximadamente $1 \mathrm{~kg}$ manualmente com a utilização de uma pá comum. Após a coleta, as amostras foram acondicionadas em sacos plásticos de polietileno, lacradas, identificadas e mantidas em refrigeração até chegada ao laboratório. As amostras de sedimentos foram dispostas em bandejas previamente lavadas com $\mathrm{HNO}_{3} 20 \% \mathrm{v} / \mathrm{v}$, cobertas com papel e colocadas para secar à temperatura ambiente.

Após a secagem, as amostras foram desagregadas e passaram por uma série de peneiras a fim de identificar sua granulometria, retirar restos de folhas, plantas, pedregulhos e objetos maiores. O material passante na peneira de $0,8 \mathrm{~mm}$ foi dividido em duas subamostras. Uma foi reservada para a aferição dos sólidos voláteis e determinação mineralógica e a outra, passada em peneira de nylon para separar a fração menor que $63 \mu \mathrm{m}$, a ser utilizada na determinação dos elementos maiores e traços.

O procedimento para avaliação da composição granulométrica é utilizado pelo laboratório de geotécnica do Instituto Federal de Goiás. Para caracterização da granulometria das amostras de sedimento, utilizou-se o jogo de peneiras com malhas nas seguintes ordens: $10 \mathrm{~mm}-5 \mathrm{~mm}-2,5$ $\mathrm{mm}-0,8 \mathrm{~mm}-0,5 \mathrm{~mm}-0,125 \mathrm{~mm}-0,1 \mathrm{~mm}$. As peneiras foram previamente limpas e encaixadas, de modo a formar um único conjunto com abertura de malha em ordem crescente da base para o topo, e fundo fechado.

Após este procedimento promoveu-se a agitação mecânica do conjunto, para permitir a separação e classificação prévia dos diferentes tamanhos de grãos da amostra. O material removido pelo lado interno é considerado como retido e o desprendido na parte inferior, como passante. $O$ material retido foi calculado em função do peso da amostra e apresentado em percentagem sobre o total da amostra.

A avaliação da composição mineral dos sedimentos foi realizada por difratometria de Raios-X (DRX), em quatro varreduras: uma da amostra total ( $\mathrm{t}$ ) e quatro da fração argila: orientada e seca ao ar (n), com etilenoglicol (g), com glicerol (gl) e aquecida (a). Utilizou-se o aparelho Rigaku modelo $D-M A X B$, com radiação de $C u K \alpha$, velocidade de varredura de $2^{\circ} /$ min e intervalo de medida de $0,05^{\circ}$. O intervalo de varredura foi de: 2 a $65^{\circ}$ para t, de 2 a $35^{\circ}$ para $n$ e de 2 a $35^{\circ}$ ou 2 a $25^{\circ}$ para $\mathrm{g}, \mathrm{gl} \mathrm{e}$ a, respectivamente. As interpretações dos difratogramas foram no software JADE 3.0 Windows, XRD Pattern Procesing for the PC, 1991-1995 Materials Data, Inc.

A determinação dos sólidos voláteis nas amostras de sedimento foi realizada por gravimetria, seguindo as normas do Standard Methods for the Examination of Water and Wastewater; porções de $2 \mathrm{~g}$ das amostras foram pesadas e colocadas para secar em estufas a 105 C por 24 horas, para determinar seu peso seco. Em seguida, as amostras foram levadas à mufla, à temperatura de $450^{\circ} \mathrm{C}$, durante 24 horas. Posteriormente, foram novamente pesadas. Estes resultados são apresentados em percentagem, obtidos pela diferença entre o peso inicial subtraído do peso final dado por: $\%=\left(P_{\text {inicial }}-P_{\text {final }}\right) * 100$. 
A técnica da espectrometria de emissão com plasma indutivamente acoplado foi utilizada para a determinação dos elementos maiores e traços. Como os metais presentes nas amostras precisam estar em solução, foi realizado o ataque das amostras com fusão de Metaborato de lítio $\left(\mathrm{LiBO}_{2}\right)$, assim, a matriz a ser analisada passou por um processo de digestão, a fim de que os metais sejam disponibilizados em solução (Boaventura, 1991). Esta técnica foi utilizada para determinar os elementos maiores: $\left(\mathrm{SiO}_{2}, \mathrm{Al}_{2} \mathrm{O}_{3}, \mathrm{Fe}_{2} \mathrm{O}_{3}, \mathrm{CaO}, \mathrm{MgO}, \mathrm{TiO}_{2}, \mathrm{Na}_{2} \mathrm{O}, \mathrm{K} \mathrm{O}_{2} \mathrm{O}\right)$. As leituras foram realizadas no ICP/OES, com resultados ajustados para $100 \%$.

As amostras foram pesadas em cadinho de platina, aproximadamente 0,05 \pm 0,0001 $\mathrm{g}$; logo após, pesou-se 0,17 $\pm 0,01 \mathrm{~g}$ de fundente $\left(\mathrm{LiBO}_{2}\right)$ no mesmo cadinho; homogeneizou-se a amostra ao fundente e conduzi-a à mufla em temperatura de $950 \stackrel{\circ}{\mathrm{C}}$ por $30 \mathrm{~min}$. Após passar pela mufla dissolveu-se em béquer de $250 \mathrm{~mL}$ com HCl a 15\% v/v aproximadamente $200 \mathrm{~mL}$; para finalizar o preparo da amostra aqueceu-a suavemente para ajudar na dissolução e transferiu a solução para o balão de $500 \mathrm{~mL}$ com água destilada e desmineralizada, homogeneizando e conduzindo para leitura.

$\mathrm{Na}$ determinação dos elementos traços foi utilizada a digestão via ácida pelo método da água régia, $1 \mathrm{~g}$ da amostra foi pesada em béquer de teflon, adicionou $3 \mathrm{~mL}$ de $\mathrm{HNO}_{3} 65 \% \mathrm{v} / \mathrm{v}$ e 10 $\mathrm{mL}$ de $\mathrm{HCl} 37 \% \mathrm{v} / \mathrm{v}$. A solução foi aquecida a $200{ }^{\circ} \mathrm{C}$ até perto do ponto de secura, em seguida foram adicionados $2 \mathrm{~mL} \mathrm{HNO}_{3} 65 \% \mathrm{v} / \mathrm{v}$ e $5 \mathrm{~mL}$ de $\mathrm{HCl} 37 \% \mathrm{v} / \mathrm{v}$, aqueceu novamente a $200{ }^{\circ} \mathrm{C}$ até 0 ponto de secura, adicionou $75 \mathrm{~mL}$ de $\mathrm{HCl} 10 \% \mathrm{v} / \mathrm{v}$, aqueceu novamente até solubilização completa do resíduo e após este procedimento, as amostras foram transferidas para balões volumétricos de $100 \mathrm{~mL}$, para posterior leitura dos elementos: $\mathrm{Ba}, \mathrm{V}, \mathrm{Cr}, \mathrm{Mn}, \mathrm{Cu}, \mathrm{Zn}, \mathrm{P}$ e Pb.

As metodologias utilizadas nas determinações físico-químicas e nos estudos de sedimentos foram baseadas no Standard Methods for the Examination of Water and Wastewater; 20aㅡ edição da American Public Health Association (APHA), da American Water Works Association (AWWA), e da Water Pollution Control Federation (WPCF). O controle analítico dos resultados foi validado por amostras de padrão internacional de concentração conhecida. Para água, foram utilizados os padrões da marca Canadá NWRI (National Water Research Institute) ION-915 e MIRAMICHI-02. Também foram usados como parâmetros a água destilada, além do balanço iônico, conforme Logan (1965). Para análise de sedimentos, foi usado o padrão da NIST (National Institute for Standards and Technology - USA) SEM 2709a San Joaquin Soil. Para aferição da metodologia de digestão e análise, também foi utilizado um padrão $C$ de rocha basalto (Boaventura e Hirson, 1987). As curvas de calibração do Espectrofotômetro de Absorção Atômica (EAA), da Espectrometria de Emissão Óptica com fonte de Plasma Indutivamente Acoplado (ICP/OES), e do aparelho de cromatografia iônica (IC) foram preparadas com soluções padrões de 1000 ppm da marca Vetec, e a partir delas, foram feitas as diluições necessárias para cada elemento. 


\subsection{INDICADORES BIOLÓGICOS: BIOINDICADORES}

$\mathrm{Na}$ análise dos bioindicadores, foram utilizados os invertebrados bentônicos, coletados nos pontos onde se realizou a coleta de água e as amostragens de sedimentos de corrente. Os bioindicadores foram coletados com um amostrador tipo Surber, com armação dobrável em aço, tela de nylon $250 \mu$ de abertura na malha, dimensões de abertura de $30 \times 30 \mathrm{~cm}$ e comprimento de $60 \mathrm{~cm}$ como ilustrado na Figura 15.

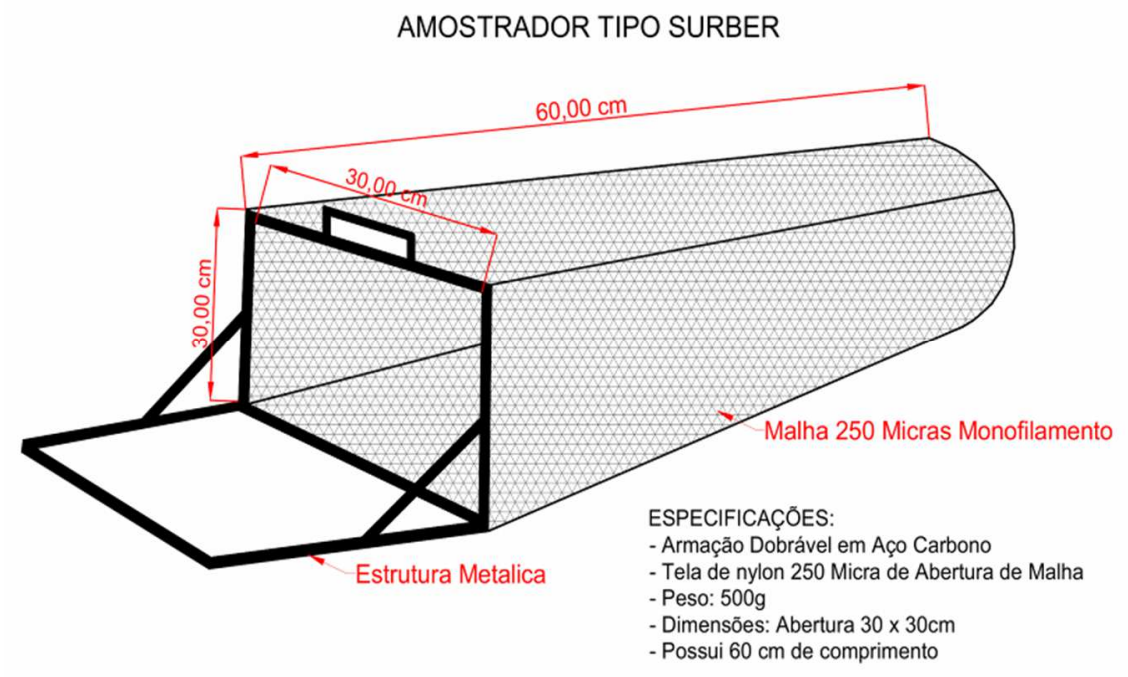

Figura 15. Especificações do amostrador de bentos tipo surber

Foram realizadas 5 réplicas de coleta por ponto em período sazonal. Após coletadas, as amostras de bentos foram acondicionadas individualmente em frascos plásticos e fixados com álcool $80 \%$ v/v, para identificação e contagem dos táxons encontrados, seguindo os trabalhos de Borisko et al, (2007), Callisto et al, (2004), Pimenta et al (2009) e Mugnai et al (2010).

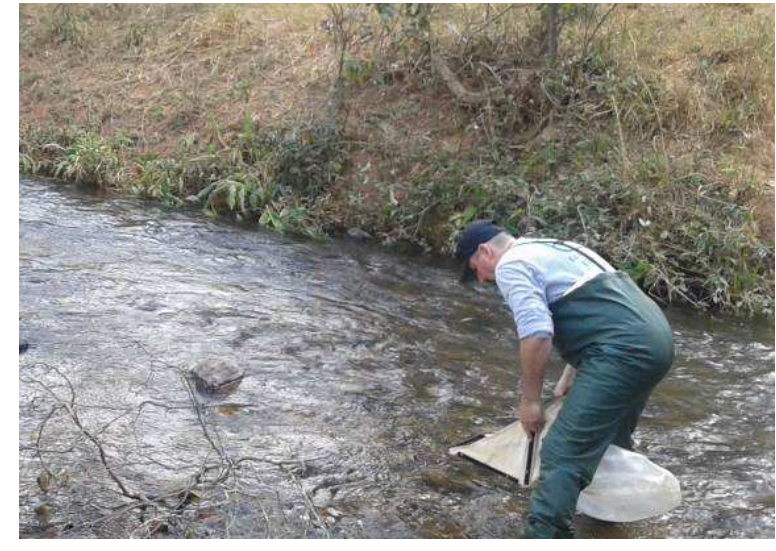

Figura 16. Coleta de bentos com a utilização do surber para amostragem

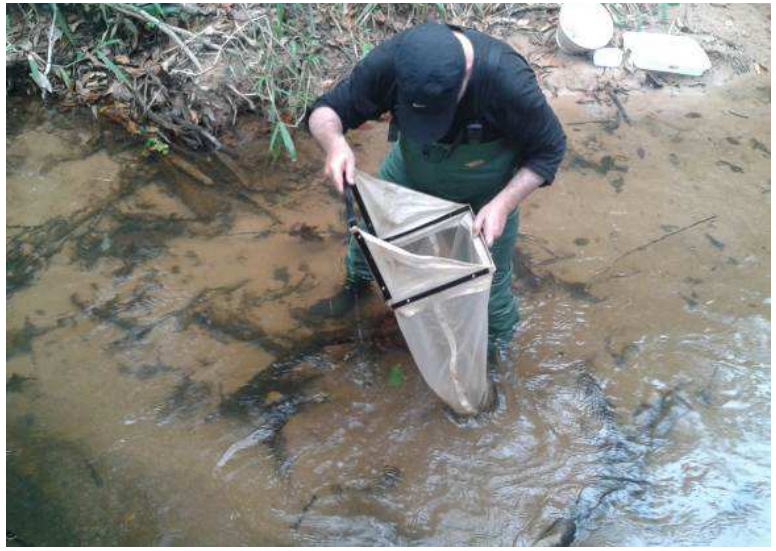

Figura 17.Detalhe do surber, utilizado nos pontos de coleta de água.

Segundo Callisto et al (2004), várias espécies podem ser utilizadas como biondicadores. Os critérios que determinaram a escolha dos táxons estão relacionados à: ampla distribuição geográfica; variedade de habitats e nichos ocupados; taxonomia bem conhecida e estável; 
facilidade de captura a baixos esforços; sensibilidade a alterações ambientais; custos e tempo de coleta reduzidos.

Após a atribuição destes critérios, foram selecionados os táxons a serem utilizados como bioindicadores, estes foram divididos segundo Callisto et al (2004) e Pimenta et al (2009), em três grupos quanto a sua tolerância: organismos sensíveis ou intolerantes (representantes de Trichoptera, Plecoptera, Ephemeroptera), organismos tolerantes (representantes de Coleóptera, Heteroptera, Odonata) e organismos resistentes (Díptera, Oligochaeta).

A figura 18 apresenta a classificação de alguns organismos resistente, tolerantes e intolerantes encontrados nos córregos Bandeirinha e Josefa Gomes. Todos os táxons utilizados estão no quadro 2. A identificação dos táxons é realizada por meio de Lupa binocular estereoscópica.
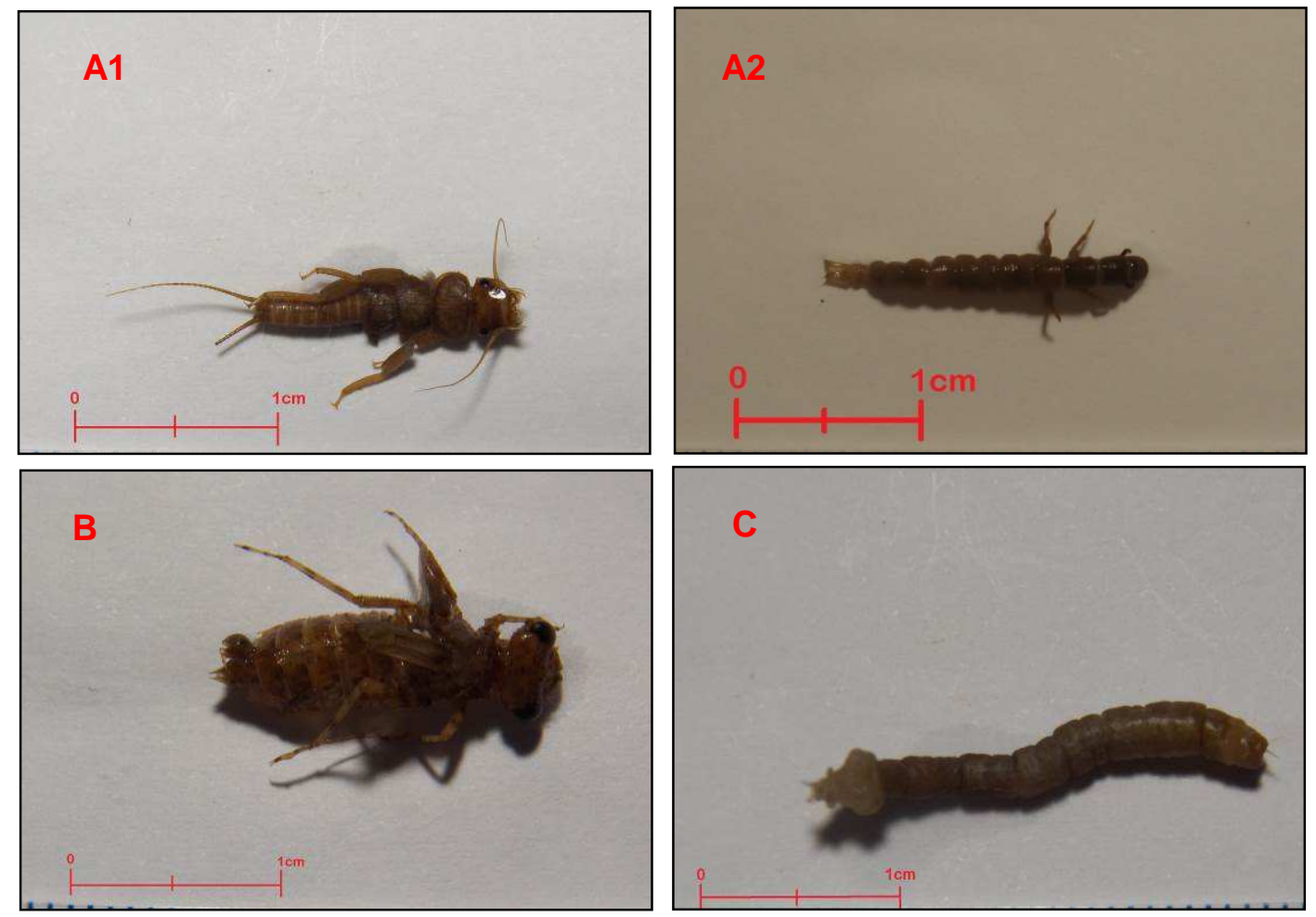

Figura 18. A1: Organismo intolerante, Ordem: Plecoptera, Família: Anacroneuria; A2: Organismo intolerante: Ordem Trichoptera, Família: Hydropsychidae; B: Organismo tolerante, Ordem: Odonata, Família: Aeshenidae; C: Organismo Resistente, Ordem: Diptera, Família: Psychodidae. 
Quadro 2. Espécies bioindicadoras utilizadas como resistentes, tolerantes e intolerantes.

\begin{tabular}{|c|c|c|c|}
\hline \multicolumn{4}{|c|}{ TÁXONS DAS ESPÉCIES BIOINDICADORAS UTILIZADAS } \\
\hline \multirow{33}{*}{ 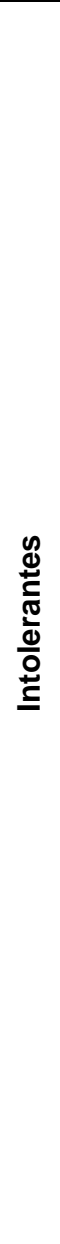 } & \multirow{18}{*}{ 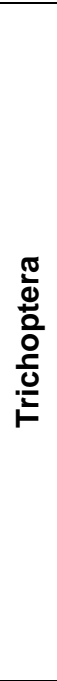 } & Calamoceratidae & Phylloicus \\
\hline & & Glossossomatidae & Mortoniella \\
\hline & & \multirow{3}{*}{ Hydroptilidae } & Alisotrichia \\
\hline & & & Hydroptilidae NI \\
\hline & & & Hydroptila \\
\hline & & \multirow{4}{*}{ Hydropsychidae } & Hydropsychidae NI \\
\hline & & & Leptonema \\
\hline & & & Smicridea \\
\hline & & & Macronema \\
\hline & & Helycopsichidae & Helicopsyche \\
\hline & & \multirow{3}{*}{ Leptoceridae } & Oecetis \\
\hline & & & Nectopsyche \\
\hline & & & Casinha \\
\hline & & \multirow{2}{*}{ Odontoceridae } & Barypenthus \\
\hline & & & Marilia \\
\hline & & \multirow{3}{*}{ Policentropodidae } & Policentropodidae NI \\
\hline & & & Chimarra \\
\hline & & & Cyrnellus \\
\hline & \multirow{15}{*}{ 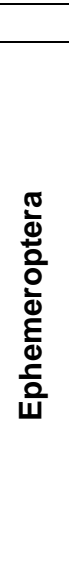 } & Plecoptera & Anacroneuria \\
\hline & & \multirow{5}{*}{ Baetidae } & Baetidae NI \\
\hline & & & Americabaetis \\
\hline & & & Baetodes \\
\hline & & & Camelobaetidius \\
\hline & & & Cloeodes \\
\hline & & \multirow{3}{*}{ Leptohyphidae } & Leptohyphes \\
\hline & & & Tricorytopsis \\
\hline & & & Tricorythodes \\
\hline & & \multirow{6}{*}{ Leptophlebiidae } & Leptophlebiidae NI \\
\hline & & & Hagenulopsis \\
\hline & & & Hylister \\
\hline & & & Massartella \\
\hline & & & Needhamella \\
\hline & & & Farrodes \\
\hline \multirow{7}{*}{ 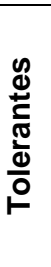 } & \multirow{4}{*}{\multicolumn{2}{|c|}{ Odonata }} & Aeshenidae \\
\hline & & & Calopterigidae \\
\hline & & & Gomphidae \\
\hline & & & \begin{tabular}{|l|} 
Libellulidae \\
\end{tabular} \\
\hline & \multirow{3}{*}{\multicolumn{2}{|c|}{$\begin{array}{c}\text { Heteroptera } \\
\text { Coleoptera }\end{array}$}} & Mesovelidae \\
\hline & & & Naucoridae \\
\hline & & & Elmidae \\
\hline \multirow{13}{*}{ 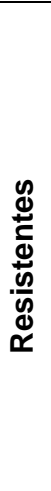 } & \multirow{8}{*}{\multicolumn{2}{|c|}{ Diptera }} & Chironomidae - larva \\
\hline & & & Chironomidae - pupa \\
\hline & & & \begin{tabular}{|l|} 
Culicidae \\
\end{tabular} \\
\hline & & & Ceratopogonidae \\
\hline & & & Empididae \\
\hline & & & Psychodidae \\
\hline & & & Simuliidae \\
\hline & & & Tipulidae \\
\hline & \multirow{2}{*}{\multicolumn{2}{|c|}{ Anellida }} & Hirudinea \\
\hline & & & Oligochaeta \\
\hline & \multirow{3}{*}{ Mollusca } & & Gastropoda NI \\
\hline & & Gastropoda & Biomphalaria \\
\hline & & Bivalvia & Bivalvia jovem \\
\hline
\end{tabular}

Para o tratamento dos dados obtidos pelos bioindicadores, foram realizados os cálculos dos índices ecológicos de diversidade Shanon (H), Equitabilidade (E) conforme Magurran, (1988) e Similaridade pelo agrupamento UGPM. Para esses cálculos, foi utilizado o programa BioDiversity Professional Version 2. 


\section{CAPÍTULO III}

\section{MODELO DE INTEGRAÇÃO}

O presente estudo propõe um novo modelo de inter-relação fundamentado no peso da evidência, utilizando os resultados de diferentes métodos de avaliação da qualidade da água: determinações físico-química, estudos de sedimentos e utilização de bioindicadores, como linhas de evidências integradas pelo modelo, proporcionando uma melhor avaliação, redução de custos e tempo.

A elaboração de modelos que buscam a integração entre dados heterogêneos das análises ambientais é evidente em diversos estudos tais como os de Dagnino et al, 2008; Linkov et al., 2009; Semenzin et al., 2008 e Benedetti et al 2011. Estes modelos podem ser elaborados para aplicações específicas sem a utilização de valores precisos, mas sim constatação geral das tendências de um conjunto de parâmetros e decisão de vários critérios de análise, ao lado de linhas de evidências, para obter um diagnóstico com resultados melhor fundamentado, reduzindo custos e tempo.

O modelo proposto foi fundamentado no peso da evidência. Conforme Linkov (2009), o peso da evidência pode ser definido como um enquadramento para a síntese de diferentes linhas de evidência, utilizando métodos que são ou qualitativos ou quantitativos, para desenvolver conclusões sobre questões relacionadas com o grau de comprometimento ou risco ambiental.

O modelo utiliza valores numéricos e atribuição de pesos e critérios de indexação, na interpretação dos resultados, que correspondem a linhas de evidências, utilizando: as determinações físico-químicas, o estudo dos sedimentos de corrente, e a identificação de bioindicadores. A diversidade dos métodos de análise ambiental aplicados possibilita complexidades que são gerenciadas usando um processo explícito ao pesar evidências, os pesos são atribuídos a cada resposta da interpretação dos resultados. Os pesos das respostas foram baseados em implicação lógica, força e qualidade dos dados.

Para cada um dos métodos aplicados, as interpretações dos resultados fornecem as linhas de evidências a serem utilizadas no modelo de integração.

Nos resultados das determinações físico-químicas são considerados a interpretação quanto à:

- Maiores aferições nos parâmetros físico-químicos em relação aos demais pontos;

- Correlação entre parâmetros indicativos de alterações de origem antrópica;

- Aferições nos parâmetros físico-químicos indicativos de atividades antrópicas.

\section{Nos resultados das determinações dos sedimentos:}

- Alteração na composição granulométrica natural dos sedimentos;

- Determinações não condizentes com a geologia local;

- Indicativos da presença de elementos maiores e traços de origem antrópica. 


\section{Na identificação de bioindicadores:}

- Reduzidos ou Ausência de Organismos Intolerantes;

- Reduzidos ou Ausência de Organismos Intolerantes e Tolerantes;

- Predominância de Organismos Resistentes.

As determinações físico-químicas e a identificação de bioindicadores estão relacionados ao período hidrológico $(\mathrm{PH})$ e respondem de forma diferente à sazonalidade, portanto, esta variável foi inserida no modelo. A sazonalidade constitui um fator importante para as determinações físicoquímicas e as variações influem diretamente na concentração e ação dos elementos no ambiente. Em períodos secos, tem-se a concentração dos elementos, enquanto nos períodos chuvosos temse a diluição e o carreamento de materiais para as drenagens superficiais. Foram atribuídos valores adimensionais de 0,2 para o período chuvoso, considerando a diluição, e 0,3 para o período seco, considerando a concentração e consequentemente, maiores aferições.

$\mathrm{Na}$ identificação dos bioindicadores, os períodos seco e chuvoso também influenciam na distribuição dos organismos em seu habitat. Em períodos secos, tem-se melhor fixação dos organismos e, consequentemente maior riqueza e diversidade, enquanto nos períodos chuvosos menor riqueza e diversidade. Os valores adimensionais considerados foram 0,3 para o período chuvoso e 0,2 para seco.

Suter (2011), esclarece que ao desenvolver linhas individuais de evidências a partir de dados disponíveis para abordar uma questão específica, requer que descreva o grau em que essas linhas de evidências apoiam uma conclusão ou alternativa específica. Neste entendimento, no presente modelo, ao pesar as evidências, a flexibilidade deriva de uma análise qualitativa pela utilização de um sistema de pontuação de critérios pré-definida. Esse procedimento segue de maneira inferencial, objetivando ser definido tão claramente como um teste estatístico ou modelo matemático.

As respostas da interpretação de cada método recebem uma nota (n) por escala arbitrária (0 a 5). Quando a interpretação dos resultados estiver tendendo a $\leq 0$ haverá menor relação com a resposta, $\geq 5$ relações forte com a reposta da interpretação.

Em seguida à interpretação dos resultados são classificadas por peso considerando a influência das análises que compõe o método (0,5 a 2). Por fim foi acrescentado a variável do período hidrológico $(\mathrm{PH})$. A soma das notas $\left(\sum \mathrm{n}\right)$, multiplicadas pelos pesos $(\mathrm{P})$ e pelo período hidrológico $(\mathrm{PH})$ dará a pontuação parcial, para cada interpretação dos resultados. $\mathrm{O}$ cálculo abaixo é expresso para as determinações físico-químicas e para as respostas dos bioindicadores:

\section{PONTUAÇÃO PARCIAL $=\Sigma \mathbf{N} \times \mathbf{P} \times \mathrm{PH}^{*}$}

N: Nota atribuída entre 0 a 5 para a interpretação dos resultados;

P: Peso de cada Interpretação;

$\mathrm{PH}^{*}$ : Período hidrológico determinações físico químicas (0,2 para chuvoso - 0,3 para seco);

$\mathrm{PH}^{*}$ : Período hidrológico Bioindicadores (0,3 para chuvoso - 0,2 para seco). 
Para os estudos de sedimentos, segue a mesmo cálculo, não atribuindo variável quanto ao período hidrológico, por este possuir menor influência nos resultados deste método. O Quadro 1, sintetiza a relação entre os métodos, os resultados e a interpretação, aplicando o peso e a intensidade.

\section{PONTUAÇÃO PARCIAL $=\Sigma \mathbf{N} \times \mathbf{P}$}

$\mathrm{N}$ : Nota atribuída entre 0 a 5 para a interpretação dos resultados

P: Peso de cada Interpretação;

Quadro 1. Diagrama lógico da relação das evidencias na aplicação do modelo

\begin{tabular}{|c|c|c|c|}
\hline Método Aplicado & PESO & $\begin{array}{l}\text { Interpretação dos Resultados } \\
\text { (Intensidade de } 0 \text { a 5) }\end{array}$ & Cálculo Aplicado \\
\hline Análises físico-químicas & $\begin{array}{l}0,5 \\
1,5 \\
2\end{array}$ & $\begin{array}{l}\text { Maiores aferições nos parâmetros físico- } \\
\text { químicos em relação aos demais pontos; } \\
\text { Correlação entre parâmetros indicativos de } \\
\text { alterações de origem antrópica } \\
\text { Aferições nos parâmetros físico-químicos } \\
\text { indicativos de atividades antrópicas }\end{array}$ & $\Sigma N F Q \times P F Q \times P H F Q$ \\
\hline Estudos dos Sedimentos & $\begin{array}{l}0,5 \\
1,5 \\
2\end{array}$ & $\begin{array}{l}\text { Alteração na composição granulométrica } \\
\text { natural dos sedimentos } \\
\text { Determinações não condizentes com a } \\
\text { Geologia local } \\
\text { Indicativos da presença de elementos maiores } \\
\text { e traços de origem antrópica }\end{array}$ & $\Sigma N S \times P S$ \\
\hline Bioindicação & $\begin{array}{c}1,5 \\
2\end{array}$ & $\begin{array}{l}\text { Reduzidos ou Ausência de Organismos } \\
\text { Intolerantes } \\
\text { Reduzidos ou Ausência de Organismos } \\
\text { Intolerantes e Tolerantes } \\
\text { Predominância de Organismos Resistentes }\end{array}$ & $\Sigma \mathrm{NB} \times \mathrm{PB} \times \mathrm{PHB}$ \\
\hline
\end{tabular}

Após a formulação das pontuações parciais por método de análise, estes serão integrados seguindo a expressão abaixo, resultando em uma pontuação final da qualidade da água.

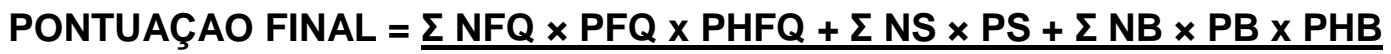 3}

NFQ: Nota atribuída entre 0 a 5 para as respostas Físico-químicas

PFQ: Peso de cada resposta Físico-química

PHFQ: Período Hidrológico Físico-químico (0,2 para chuvoso - 0,3 para seco)

NS: Nota atribuída entre 0 a 5 para respostas dos sedimentos

PS: Peso de cada resposta dos Sedimentos

NB: Nota atribuída entre 0 a 5 para as respostas Bioindicadores

PB: Peso de cada resposta Bioindicadores

PHB: Período Hidrológico Bioindicadores (0,3 para chuvoso - 0,2 para seco) 
A determinação da pontuação final é efetuada por meio da interpretação entre os resultados obtidos, de forma a aferir e integrar os métodos de avaliação da qualidade da água. A classificação final das condições do ponto de amostragem é representada pelo intervalo. Figura 1.

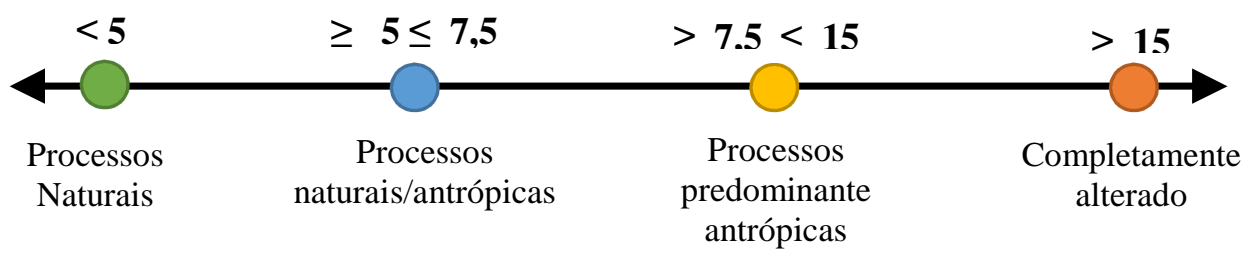

Figura 1. Intervalo para classificação final, integrando os métodos de análise.

O esquema abaixo representa de forma sucinta a proposta de modelo para integração dos resultados.

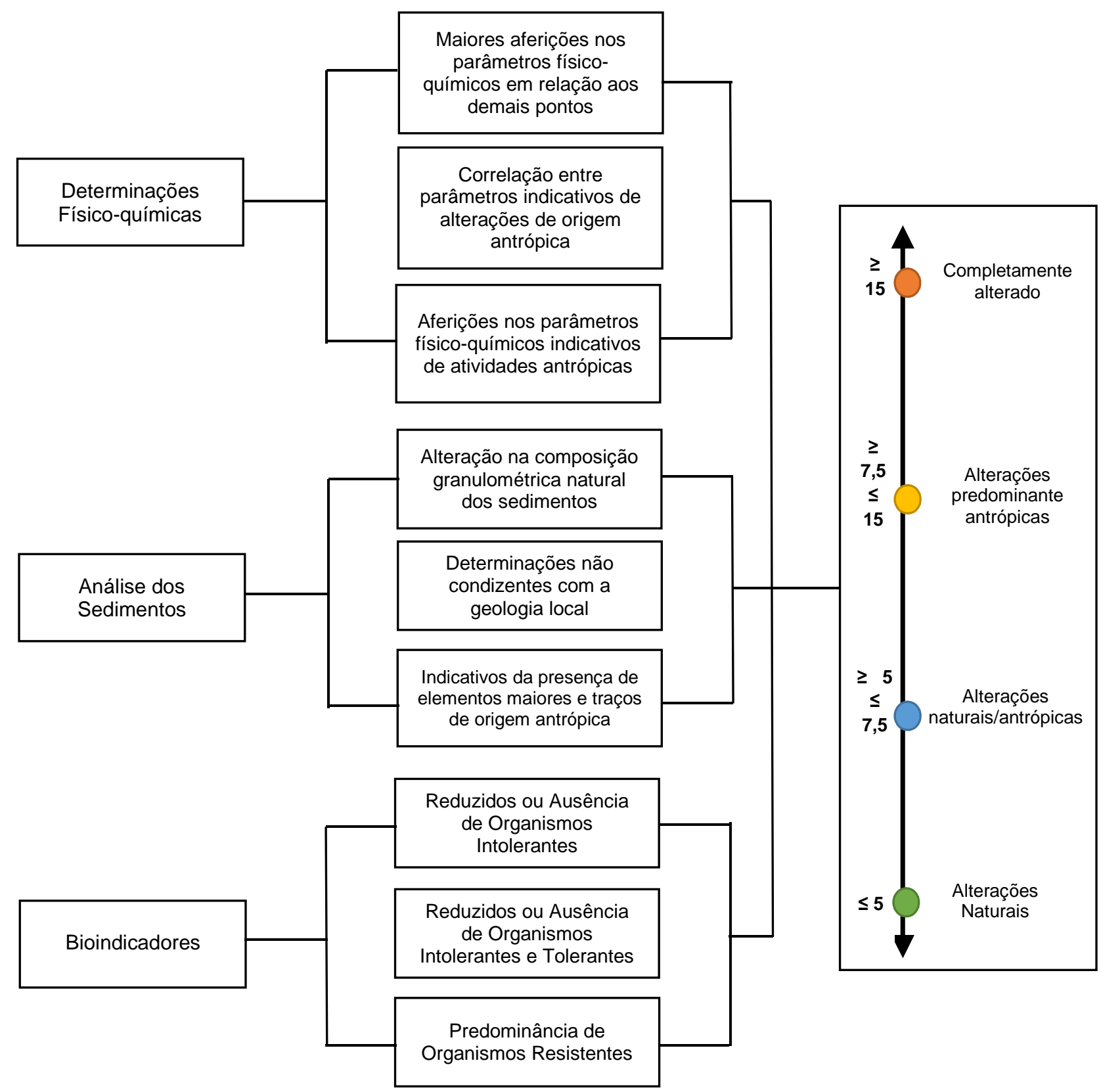

Figura 2. Fluxograma lógico do modelo de pesos da evidência fundamenta nas respostas das determinações físico-químicas; estudo dos sedimentos e espécies bioindicadoras. 


\subsection{APLICAÇÃO DO MODELO}

$\mathrm{Na}$ aplicação do modelo a interpretação das linhas de evidência, foram elaboradas em formato de artigos e submetidos a publicação. Estes artigos correspondem aos períodos seco e chuvoso do ano de 2013 nos córregos Bandeirinha e Josefa Gomes. O primeiro artigo teve como objetivo realizar as determinações físico-químicas para a avaliação da qualidade da água. Foi submetido e aceito para publicação na Revista Ibero-Americana de Ciências Ambientais. Submetido em 12/09/2014 e aceito para publicação em 09/04/2015.

O segundo artigo trata do estudo dos sedimentos de corrente nas duas drenagens, que complementam o modelo, apresentado a caracterização granulométrica, a determinação de sólidos voláteis, a mineralogia e a determinação de elementos maiores e traços. $\mathrm{O}$ artigo foi submetido a Revista de Ciências Ambientais em 12/03/2015 e aceito para publicação em 09/09/2015.

O terceiro artigo apresenta a avaliação da qualidade da água por meio de bioindicadores da comunidade bentônica. Submetido a Revista Ambiente e Água em 02/07/2015 e aceito para publicação em 19/11/2015.

O quarto artigo apresenta o modelo proposto de integração dos métodos a aplicação e validação deste, em ambiente urbano e rural nos períodos chuvoso e seco de 2013. O artigo foi elaborado conforme as normas do periódico Environmental Monitoring and Assessment.

Foi realizada a verificação da reprodutibilidade da abordagem, com o modelo aplicado no período seco e chuvoso de 2013 , reproduzido no período seco e chuvoso de 2015. Os resultados são apresentados no Capítulo VIII. 


\section{"QUALIDADE DA ÁGUA E CORRELAÇÃO DE PARÂMETROS FíSICO-QUíMICOS EM DRENAGENS URBANA E RURAL DE FORMOSA/GO".}

Artigo submetido em 12/09/2014, no periódico: Revista Ibero-Americana de Ciências Ambientais RICA, e publicado v. 6 , n. 1 (2015).

17/11/2015 QUALIDADE DA ÁGUA E CORRELAÇÃO DE PARÂMETROS FISICO-QUÍMICOS EM DRENAGENS URBANA E RURAL DE FORMOSAVG.

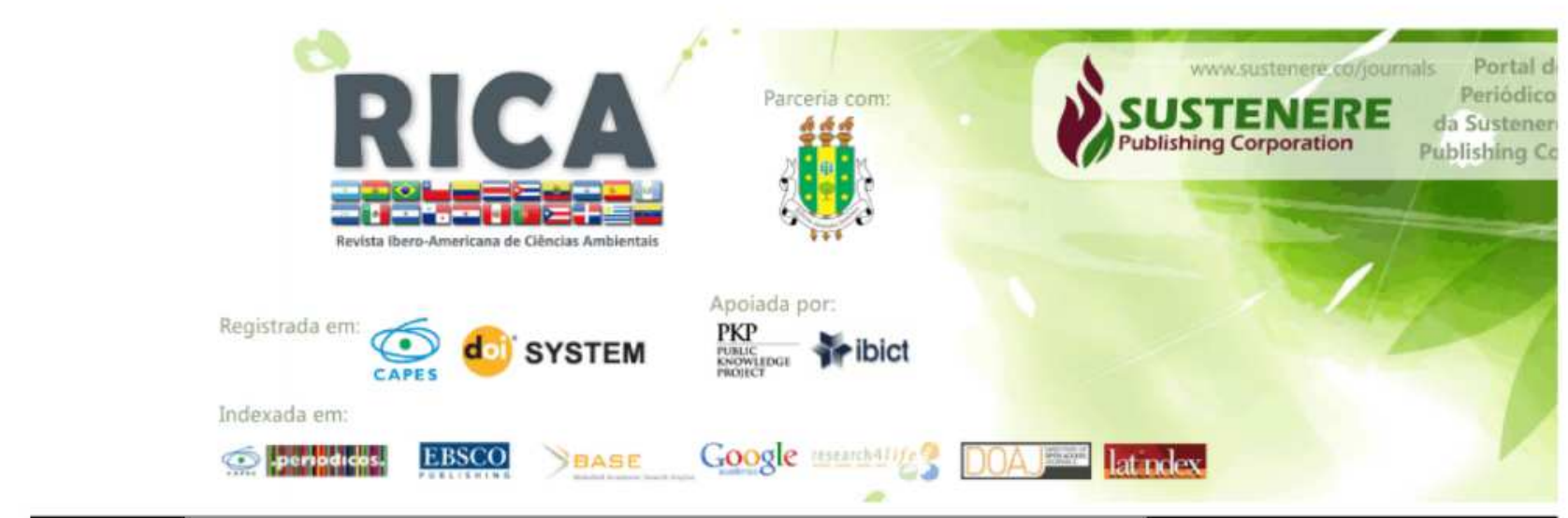

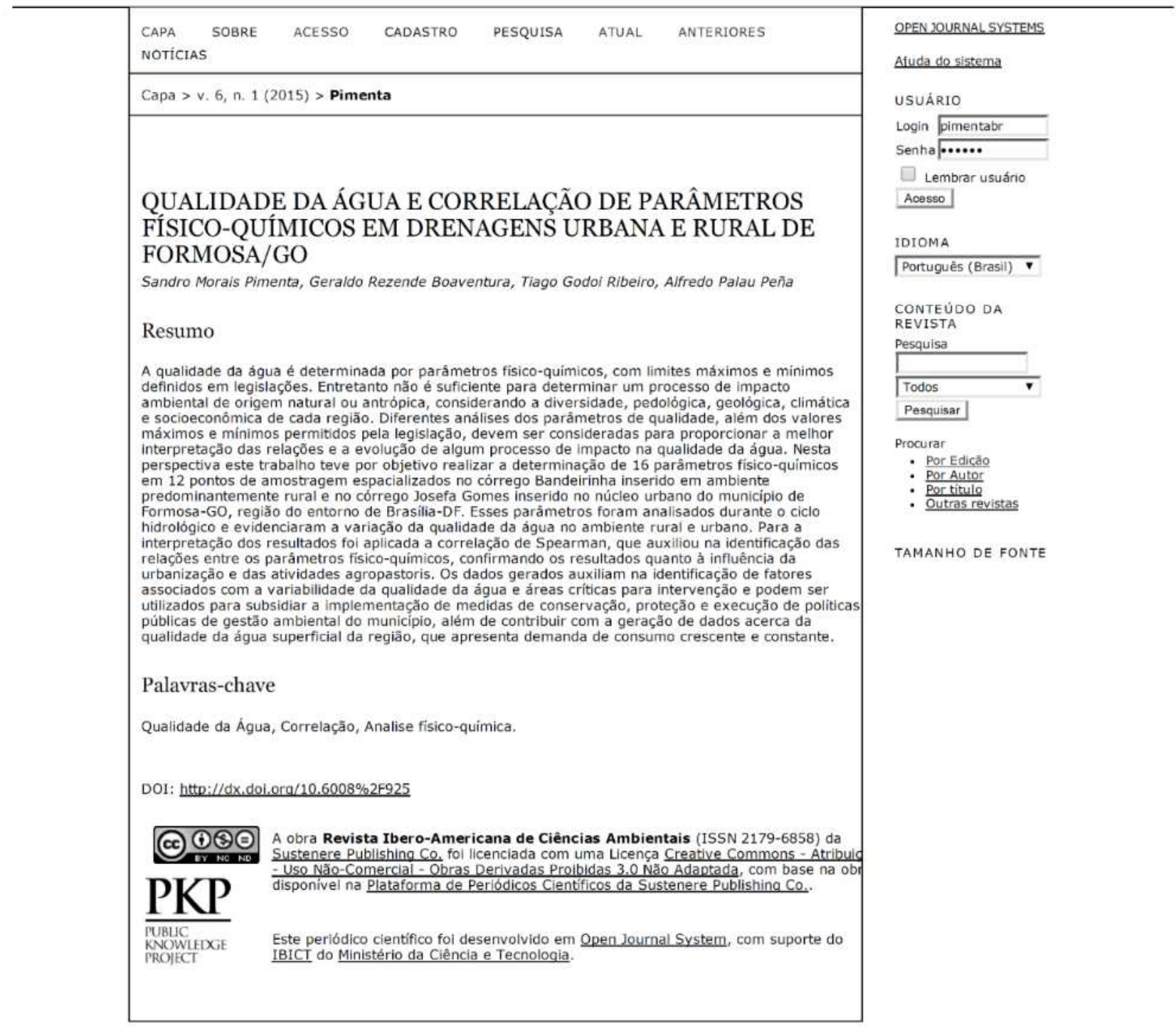




\section{QUALIDADE DA ÁGUA E CORRELAÇÃo dE PARÂMETROS FísıCO-QUímICOS EM DRENAGENS URBANA E RURAL DE FORMOSA/GO}

\section{RESUMO}

A qualidade da água é determinada por parâmetros físico-químicos, com limites máximos e mínimos definidos em legislações. Entretanto não é suficiente para determinar um processo de impacto ambiental de origem natural ou antrópica, considerando a diversidade, pedológica, geológica, climática e socioeconômica de cada região. Diferentes análises dos parâmetros de qualidade, além dos valores máximos e mínimos permitidos pela legislação, devem ser consideradas para proporcionar a melhor interpretação das relações e a evolução de algum processo de impacto na qualidade da água. Nesta perspectiva este trabalho teve por objetivo realizar a determinação de 16 parâmetros físico-químicos em 12 pontos de amostragem espacializados no córrego Bandeirinha inserido em ambiente predominantemente rural e no córrego Josefa Gomes inserido no núcleo urbano do município de Formosa-GO, região do entorno de Brasília-DF. Esses parâmetros foram analisados durante os períodos chuvoso e seco e evidenciaram a variação da qualidade da água no ambiente rural e urbano. Para a interpretação dos resultados foi aplicada a correlação de Spearman, que auxiliou na identificação das relações entre os parâmetros físico-químicos, confirmando os resultados quanto à influência da urbanização e das atividades agropastoris. Os dados gerados auxiliam na identificação de fatores associados com a variabilidade da qualidade da água e áreas críticas para intervenção e podem ser utilizados para subsidiar a implementação de medidas de conservação, proteção e execução de políticas públicas de gestão ambiental do município, além de contribuir com a geração de dados acerca da qualidade da água superficial da região, que apresenta demanda de consumo crescente e constante.

Palavras-chave: Qualidade da água, correlação, analises físico-química.

\section{WATER QUALITY AND A CORRELATION BETWEEN THE PHYSICAL-CHEMICAL PARAMETERS DRAINS URBAN AND RURAL IN FORMOSA/GO}

\section{ABSTRACT}

Water quality is determined by physicochemical parameters, and their maximum and minimum limits set in legislation, however, is not sufficient to determine a process of environmental impact of natural or anthropogenic origin, considering the diversity, pedological, geological, climatic and socioeconomic in each region. Different analyzes of the quality parameters beyond the minimum and maximum values allowed by the legislation must be considered to provide the best interpretation of the relations and the evolution of some process of impact on water quality. In this perspective, this work aimed to make the determination of 16 physicochemical parameters in 12 points spatially sampling the stream Bandeirinha inserted in predominantly rural environment and stream Josefa Gomes inserted in the urban core of the municipality of Formosa-GO the region around Brasília-DF. These parameters were analyzed during the rainy and dry seasons and showed the variation of water quality in rural and urban environment. In interpreting the results Spearman who assisted in the identification of relationships between physicochemical parameters, confirming the results about the influence of urbanization and agropastoral activities was applied. The data generated help identify factors associated with the variability of water quality and critical areas for intervention can be used to support the implementation of conservation measures and protection, the development and implementation of public policies for environmental management of the municipality, in addition contribute to the generation of data on surface water quality in the region, which has increased demand and rising consumption.

Keywords: Water quality, correlation, analysis physicochemical. 


\section{INTRODUÇÃO}

A obtenção de informações integradas, a respeito de um corpo hídrico, depende do estudo das interações que ocorrem entre os fatores do meio físico, biótico e antrópico na área avaliada. Essas interações estão vinculadas a uma escala temporal, refletindo um comportamento dinâmico, intrínseco a cada ambiente. Nas drenagens superficiais estão presentes diversos elementos químicos em proporções e origens diversas, fato que atribui às águas superficiais características específicas, de acordo com a variação quantitativa e qualitativa dos elementos constituintes.

Sperling (2007) ressalta que essas características, podem ser expressas em forma de parâmetros de qualidade da água, sendo utilizados na avaliação de águas de abastecimento, águas residuárias e drenagens superficiais.

As condições do meio físico afetam a qualidade da água ao incorporar na rede de drenagem, o material que está suspenso na atmosfera, além da contribuição do escoamento superficial e elementos diversos provenientes da dissolução de rochas, conforme as características geológicas de cada região.

Carmo et al (2005), apontaram que as atividades antrópicas que comprometem a qualidade da água estão relacionadas ao uso não controlado de insumos agrícolas e ao lançamento de efluentes industriais e domésticos. A distribuição de elementos químicos depende não somente das concentrações, mas também das reações físico-químicas nos ambientes, diretamente influenciadas pelas condições ambientais, intemperismo natural e ações antrópicas.

Conforme Santos et al (2012) diversos estudos em drenagens superficiais indicam como possível fonte dos elementos: $\mathrm{Cu}, \mathrm{Fe}, \mathrm{Ni}, \mathrm{Al}, \mathrm{Cr}, \mathrm{Mn}, \mathrm{Zn}$ e $\mathrm{Cd}$, o uso e ocupação do solo, seja em área urbana, ou rural. A utilização de insumos nas atividades agropastoris auxilia no aumento da produtividade em relação à área cultivada, contudo, gera impactos ambientais no solo e nas drenagens superficiais, além da possibilidade de intoxicação das comunidades próximas por meio da ingestão progressiva destes produtos. Em áreas urbanas temos a utilização de combustíveis, lubrificantes, produtos de limpeza, atividades industriais e outras inseridas no ambiente urbano, possível fonte antrópica destes elementos.

O crescimento urbano em direção aos rios tem apresentado grandes reflexos na qualidade das águas, com altos custos econômicos e sociais, tornando a disponibilidade hídrica um fator limitante ao próprio desenvolvimento das cidades. A qualidade da água é fundamental para o bemestar da população. Os impactos gerados pela crescente urbanização geram a efetiva redução da disponibilidade dos recursos hídricos e do potencial de utilização.

Cyril e Weng (2010) destacaram que o exponencial crescimento das áreas urbanas e atividades agropastoris implicam nas mudanças do uso e cobertura do solo, para atender ao crescimento populacional e alteraram significativamente a qualidade da água de superfície. Estes 
autores realizaram o estudo demostrando que o nível de concentração de poluentes de fontes difusas nas águas de superfície, dentro de uma bacia, depende muito das relações entre a época e a área que contribuem para o escoamento superficial.

A alteração da qualidade da água em drenagens superficiais, independente da fonte, esgotos domésticos, esgotos industriais, água de escoamento superficial, resíduos sólidos, causa modificações em suas características físicas, químicas e biológicas, afetando um determinado uso previsto para o recurso hídrico.

Poudel et al (2013) ressaltaram que a decomposição de materiais orgânicos nas drenagens resulta na adição de nitrogênio, fósforo, e outros elementos na água, além da poluição difusa de substâncias dissolvidas, tais como cloreto $\left(\mathrm{Cl}^{-}\right)$, sulfato $\left(\mathrm{SO}_{4}{ }^{2-}\right)$, e carbonatos $\left(\mathrm{CO}_{3}{ }^{2-}\right)$, que também alteram a qualidade das drenagens superficiais, proveniente da aplicação de fertilizantes, calcário, intemperismo das rochas, defensivos agrícolas, ou a partir do escoamento urbano.

Para a avaliação da qualidade das águas pode-se utilizar diversos métodos, os quais apresentam inicialmente, o estado da água em uma bacia hidrográfica, inserida em área rural ou urbana, este é um instrumento importante da gestão ambiental. Consistem na realização das análises dos parâmetros físico-químicos, produzindo informações e dados, das áreas de influência de atividades antrópicas, potencialmente impactantes e limitantes dos diversos usos dos recursos hídricos. Esta análise é destinada às diversas instâncias legais pertinentes, bem como à comunidade científica e ao público em geral.

As exigências quanto à qualidade da água são diretamente relacionadas ao uso a que se destina. Os gestores estabelecem dispositivos legais como resoluções, portarias, normas e leis, que apresentam os valores máximos e mínimos permitidos, com elementos ou características desagradáveis que, podem estar presentes na água, sem que está se torne inconveniente para um determinado uso.

No âmbito da legislação brasileira, os parâmetros físico-químicos de qualidade de água possuem suas referências quantitativas nos Valores Máximos Permitidos - V.M.P, determinados pela resolução CONAMA 357/05. A legislação federal determina os V.M.P para os parâmetros de qualidade de água, contudo não é suficiente para distinguir um processo de impacto ambiental de origem antrópica ou natural, quando consideradas as diferenças morfoclimáticas, geológicas, pedológicas e socioeconômicas de cada região.

A preocupação com a qualidade da água tem se tornado uma necessidade permanente. Conforme Rodriguez et al (2014), nos últimos anos, fatores políticos e técnicos como modelagem da qualidade da água, monitoramento de nutrientes e sedimentos, concentrações de pesticidas e poluentes nos córregos e rios, influenciaram mudanças nas políticas ambientais. 
Le et al (2014) ressaltam que a eficiência para a tomada de decisão quanto à gestão da qualidade da água é fundamental para redução de custos financeiros e ambientais. Os autores propõem em seu estudo um modelo de qualidade de água aglomerado, com sensibilidade e análise de incerteza, e um domínio de gerenciamento, incluindo a estimativa de perda e valor da análise da informação e consequentemente, indo além dos valores máximos e mínimos determinados pelos órgãos ambientais para os parâmetros de qualidade da água.

Poudel et al (2013), destacam que devido à interação entre os parâmetros é possível explicar a variabilidade na qualidade da água de superfície utilizando alguns grupos de parâmetros. Em seus estudos, os autores realizaram a análise da qualidade da água utilizando 13 parâmetros físicoquímicos ( $\mathrm{DBO}_{5}$; Totais de Sólidos Suspensos; $\mathrm{NO}_{3}$; Nitrogênio Total; Fósforo Total; Fósforo Reativo Solúvel; Temperatura; Condutividade Elétrica; Totais de Sólidos Dissolvidos; pH; Turbidez; Oxigênio Dissolvido; Nitrogênio Total Kjeldahl) e interpretaram os resultados com técnicas de análise estatísticas não paramétricas. A aplicação das análises estatísticas e a interação dos parâmetros proporcionou uma melhor interpretação quanto às alterações na qualidade da água da drenagem avaliada.

Na realização da avaliação da qualidade da água é fundamental considerar a sazonalidade da área em questão. Zhang et al (2013) realizaram a comparação dos impactos da vazão do rio sobre a qualidade das águas superficiais do Rio Xiangjiang, na China, utilizando 12 parâmetros de qualidade da água de superfície em 31 pontos de amostragens, de janeiro de 1998 a dezembro de 2008. Ao longo da drenagem principal constatou-se que concentrações significativamente maiores de nitrogênio total, nitrogênio amoniacal, fósforo total, e $\mathrm{DBO}_{5}$ ocorreram durante os períodos de seca da região, o que implica a necessidade de um maior controle dos órgãos ambientais nesta época.

Este trabalho teve por objetivo a avaliação dos parâmetros físico-químicos de qualidade de água durante os períodos chuvoso e seco e a correlação dos resultados, aplicados em duas drenagens superficiais: o córrego Bandeirinha inserido em ambiente predominantemente rural e o córrego Josefa Gomes inserido no núcleo urbano do município de Formosa-GO, região do entorno de Brasília-DF.

Assim como outros municípios do entorno de Brasília, a forma e a velocidade do processo de ocupação urbana em Formosa, impulsionado pela proximidade da capital federal, refletiram fortemente sobre os recursos naturais e o meio social. A escolha das duas drenagens para 0 desenvolvimento do estudo deu-se por possuírem características distintas, porém localizadas na mesma região. O estudo também contribui para a geração de dados acerca da qualidade da água superficial da região, que apresenta demanda de consumo crescente e constante. 


\section{MATERIAL E MÉTODOS}

\section{Área de Estudo}

A área para o desenvolvimento da pesquisa são os córregos Bandeirinha e Josefa Gomes localizados no município de Formosa-GO, microrregião do entorno de Brasília (Figura 01). Possui uma população de 100.085 habitantes (IBGE, 2012). A sede municipal situa-se a $70 \mathrm{~km}$ de Brasília. A agropecuária é atividade estruturante na economia de Formosa, principalmente a pecuária de corte e leite.

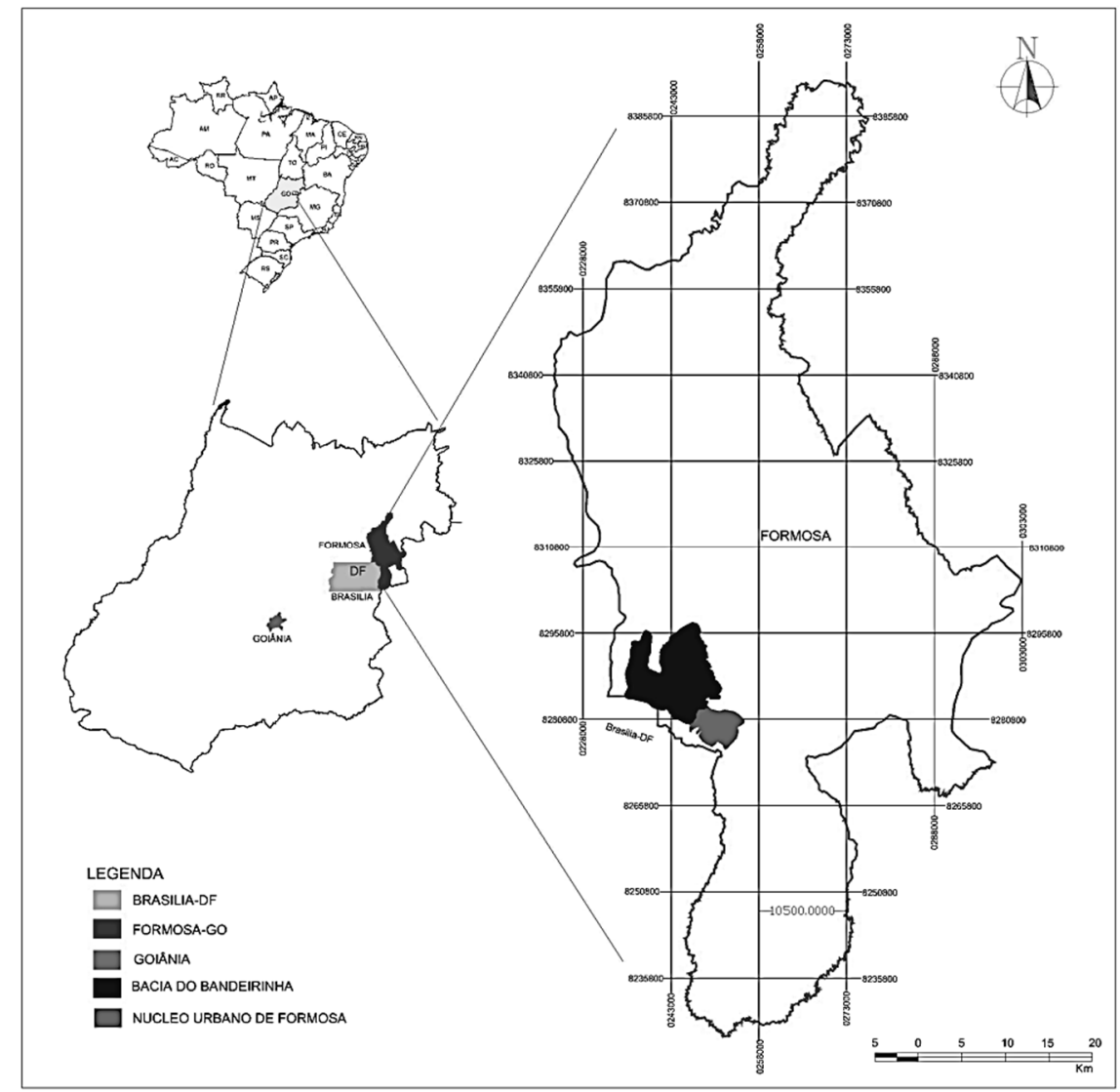

Figura 1: Localização do município de Formosa-GO Fonte: IBGE 2012, Organização Final, Pimenta 2014.

A região onde está inserido o município de Formosa possui clima tipo Aw, caracterizado por duas estações bem definidas: uma seca, que corresponde ao outono e inverno nos meses de maio a setembro, e a outra úmida com chuvas torrenciais, correspondendo ao período de primavera e verão nos meses de outubro a abril. O período de inverno apresenta estabilidade climática e reduzida precipitação. A distribuição pluviométrica é padrão típico da região Centro-Oeste do Brasil e do domínio morfoclimático dos Cerrados, com precipitação média anual na ordem de $1.485 \mathrm{~mm}$, e temperatura média anual em torno de $21,5^{\circ} \mathrm{C}$.

A carta geológica do Serviço Geológico do Brasil CPRM (2004) SD 23, folha Brasília, apresenta para a região do município de Formosa, a ocorrência de rochas do Proterozóico, representado pelo Grupo Paranoá de idade mesoproterozóica e Grupo Bambuí, Subgrupo 
Paraopeba de idade neoproterozóica, coberturas Detrito-Lateríticas do Terciário-Quaternário e Aluviões recentes nas margens dos cursos de água.

Guimarães (1997) destaca que na região de Formosa-Bezerra-Cabeceiras, o Grupo Paranoá é exposto no centro de grandes anticlinais inversos de flancos falhados, podendo estar recoberto pelos diamictitos glaciais da Formação Jequitaí ou diretamente pelos carbonatos do Grupo Bambuí.

Por meio de estudos sedimentológicos e petrográficos das rochas dos grupos Paranoá e Bambuí, Guimarães (1997) aponta que as rochas de ambas as unidades se originaram em contextos tectônicos distintos e que os sedimentos são provenientes de rochas-fontes diferentes. As rochas do Grupo Paranoá são arenitos e pelitos, formados por sedimentos cratônicos, depositados lentamente sobre uma bacia tectonicamente estável. As rochas terrígenas do grupo Bambuí são mineralógica e texturalmente imaturas, tendo os sedimentos se acumulado em uma bacia sobre influência de processos colisionais.

Fundamentado no mapeamento geomorfológico da Folha SD 23 Brasília elaborado por Mauro et al (1982), o município de Formosa e a área de estudo do córrego Bandeirinha e córrego Josefa Gomes se insere nos domínios dos Planaltos em Estruturas Sedimentares Concordantes, este domínio compreende a unidade geomorfológica Chapadas do Distrito Federal, integrante da região geomorfológica Planalto Goiás-Minas.

Chaves et al (2014) destacaram que a Região dos Planaltos de Goiás-Minas é formada pelas Chapadas do Distrito Federal, que se caracteriza por modelados constituídos principalmente de uma superfície de aplainamento degradada e retocada pela dissecação incipiente, produzida pelos Rios São Bartolomeu e Preto. No sudeste da cidade de Formosa, os topos tabulares do planalto são mantidos por couraças ferruginosas constituídas por fragmentos de rocha. Nessa região estão presentes várias classes de solos, destacam-se os latossolos, os argissolos, os cambissolos, os Neossoloslitólicos, Neossolos Quartzarênicos, os Plintossolos e os Neossolos Flúvicos.

A caracterização preliminar do contexto geológico e geomorfológico é importante para a compreensão da relação entre as rochas e suas estruturas que controlam as feições geomorfológicas, os tipos e composição de solos, os reservatórios subterrâneos o condicionamento das águas superficiais, e o aporte de elementos químicos nos solos e água.

O córrego Bandeirinha é o manancial utilizado pelo sistema de abastecimento de água do município. Está inserido em área predominantemente rural, com percurso de aproximadamente 42 km, direção Norte, desaguando no Rio Paranã, pertence à bacia Amazônica. Por meio de levantamento na área constatou-se pela classificação de Strahler (1957) que os cursos de água na bacia são de $1^{\underline{a}}$ a $4^{\underline{a}}$ ordem e apresentam características lóticas de planalto, com pequenas corredeiras a cachoeiras sobre lajes, e seus pequenos contribuintes de $1^{\underline{a}}$ a $2^{\underline{a}}$ ordem são 
geralmente cursos temporários. Suas margens estão acompanhadas de matas de galeria com enclaves de cerrado, mata estacional e áreas modificadas formadas por pastos.

O córrego Josefa Gomes, está completamente inserido em ambiente urbano, tem percurso de 7,5 km direção sudoeste e sua nascente localiza-se no parque municipal Mata da Bica. O córrego Josefa Gomes pela classificação de Strahler (1957) é uma drenagem de 3o ordem onde seus contribuintes de $1^{\underline{a}}$ a $2^{\underline{a}}$ ordem, são cursos temporários, parte do percurso do córrego Josefa Gomes, aproximadamente $1,5 \mathrm{~km}$, é retificado. Após a retificação o córrego Josefa Gomes percorre aproximadamente $6 \mathrm{~km}$ e deságua na Lagoa Feia. Em seguida a Lagoa Feia o córrego é denominado de Rio Preto percorrendo os Estados de Goiás, Distrito Federal e Minas. O Rio Preto é um dos principais tributários do rio Paracatu, no Estado de Minas Gerais, e este é um importante afluente do Rio São Francisco.

\section{Amostragem}

Para a realização do estudo foram selecionados 08 pontos no córrego Bandeirinha, e 04 pontos no córrego Josefa Gomes. A seleção dos pontos de amostragem ocorreu a partir da análise dos seguintes critérios: atividades antrópicas ao longo da drenagem, incidência de tributários na rede de drenagem, possíveis fontes de poluição identificadas e acessibilidade dos pontos selecionados. As coletas ocorreram nos meses de janeiro e setembro de 2013 , de acordo com os períodos chuvoso e seco da região. Os pontos de coleta são apresentados na Tabela 1, espacializados conforme a Figura 2.

Tabela 01: Córrego Bandeirinha e Josefa Gomes, pontos de amostragem e referência de localização.

\begin{tabular}{cccc}
\hline Pontos & Coordenadas U.T.M & Elevação $(\mathbf{m})$ & Referência de Localização \\
\hline \multicolumn{4}{c}{ Córrego Bandeirinha } \\
\hline PB1 & $236493,72-8285621,08$ & 1076,79 & Fazenda Asa Branca \\
PB2 & $238214,31-8290682,55$ & 1039,06 & Córrego Cachoeira Alta \\
PB3 & $239970,07-8287121,16$ & 999,64 & Fazenda Asa Branca \\
PB4 & $242870,84-8284033,05$ & 982,34 & Captação Água (SANEAGO) \\
PB5 & $248426,21-8284776,50$ & 800,89 & Rodovia GO 116 \\
PB6 & $248773,91-8287121,41$ & 708,85 & Rodovia GO 116 \\
PB7 & $246708,56-8291243,96$ & 661,98 & Fazenda Jenipapo \\
PB8 & $246891,00-8297253,00$ & 605,75 & Fazenda Santo Estevão \\
\hline \multicolumn{4}{c}{ Córrego Josefa Gomes } \\
\hline PJ1 & $249564,69-8278950,81$ & 926,83 & Nascente Paq. Mun. Mata da Bica. \\
PJ2 & $250132,09-8280902,66$ & 902,07 & Final Trecho Retificado, Av. \\
PJ3 & $251728,59-8281177,27$ & 888,13 & Adutora Água Trat. Rua Ametista \\
PJ4 & $252937,47-8280043,56$ & 879,96 & Rua 24, Ponte da Av. B \\
\hline
\end{tabular}




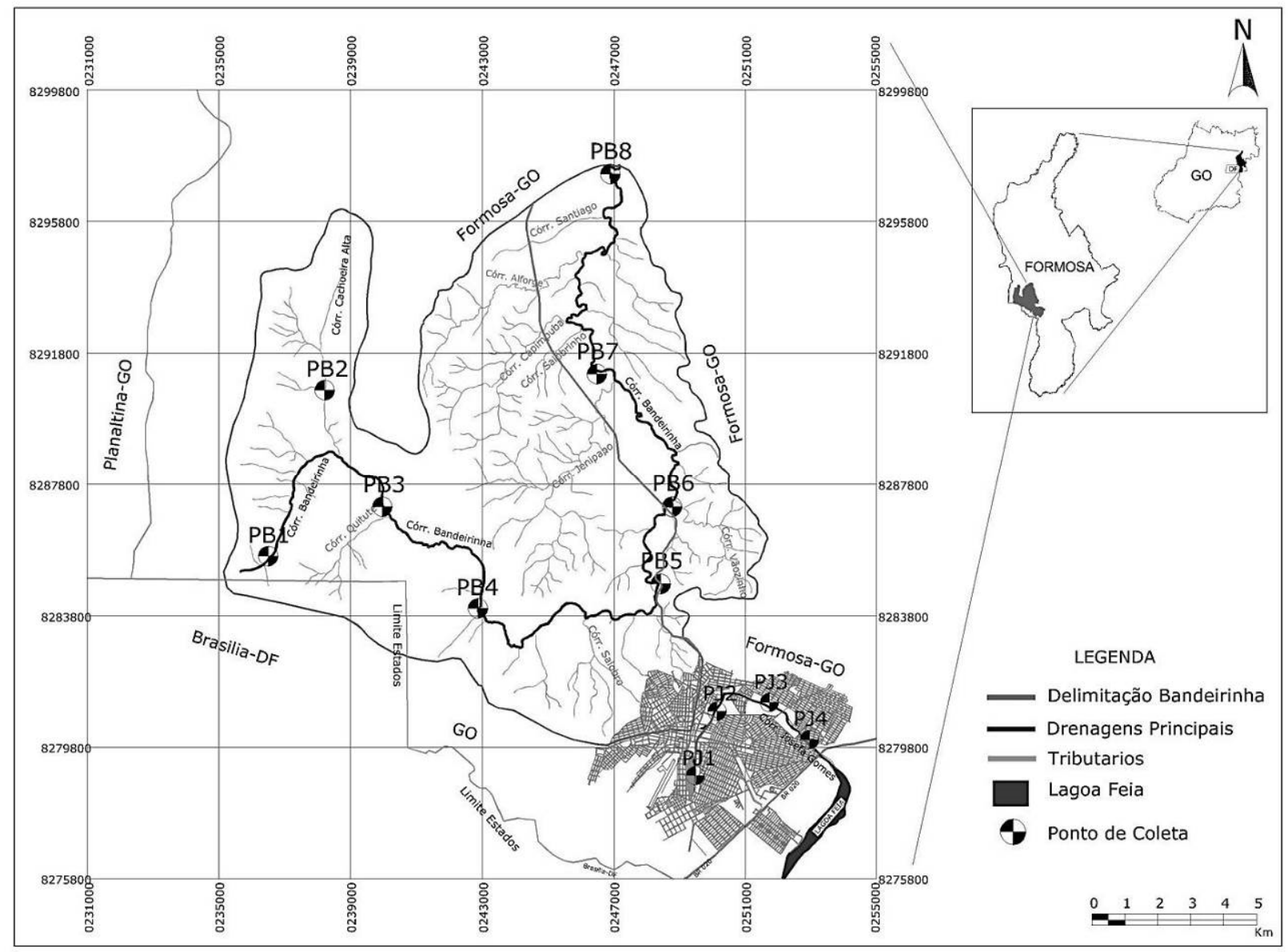

Figura 2: Pontos de amostragem córrego Bandeirinha e Josefa Gomes, Formosa-GO. Fonte: IBGE 2012, Organização Final, Pimenta 2014.

Os 08 pontos de coleta no córrego Bandeirinha seguem do nascente montante para desague jusante no Rio Paranã. Seu percurso é predominante na área rural do município, sendo assim caracterizados: Ponto PB1 próximo à área de nascente, na Fazenda Asa Branca e recebe influência das atividades agropastoris desta área, dista cerca de 300 metros das nascentes do córrego Bandeirinha.

O ponto PB2 é um dos tributários do córrego Bandeirinha, o córrego Cachoeira Alta. Este ponto de amostragem está inserido em área rural, próximo cerca de 800 metros de uma produção de hortaliças.

O ponto PB3 está em área rural, também localizada na Fazenda Asa Branca, contudo esta área é utilizada para a pecuária extensiva, e mantêm as margens protegidas, onde foi observada uma faixa de aproximadamente 30 metros de vegetação ciliar.

O ponto PB4 está na área de captação de água do córrego Bandeirinha, utilizada pela concessionária de Saneamento de Goiás - SANEAGO, para o abastecimento do município de Formosa, localizada na Fazenda Bandeirinha. Esta área é utilizada para a implantação de uma nova barragem. O solo do local da construção da barragem está em parte, desprovido de vegetação 
nativa, ocupado por remanescentes de pastagens e parte abriga a atual estação de bombeamento de água.

Os pontos PB5 e PB6 estão localizados a jusante do núcleo urbano do município, próximos a rodovia GO 116, e recebem a influência deste. Constatou-se na saída da rodovia GO 116, direção Norte, a presença de um depósito de resíduos sólidos urbanos e da construção civil, no limite urbano do município próximo ao córrego Salobro, tributário do Bandeirinha, a montante dos pontos PB5 e PB6.

O ponto PB7 está localizado na Fazenda Jenipapo, logo após o deságue do córrego Jenipapo, tributário da bacia do Bandeirinha, suas margens e área de proteção permanente encontram-se preservadas. O ponto PB8 está localizado na Fazenda Santo Estevão, próximo ao exutório da bacia do Bandeirinha no Rio Paranã, que também possui as margens protegidas com a presença de vegetação e densa área de proteção permanente.

Os 04 pontos de amostragem no córrego Josefa Gomes, seguem da nascente no parque municipal Mata da Bica, até seu deságue na Lagoa Feia. O ponto PJ1 foi amostrado próximo a nascente dentro do parque municipal Mata da Bica. O Ponto PJ2 está localizado logo após o término do trecho de 1,5 km retificado do Josefa Gomes, no final da Avenida Ivone Sadd e encontro da Avenida Califórnia. Sua margem apresenta resíduos sólidos, odor característico de efluente doméstico, além do lançamento de drenagem pluvial oriunda das Avenidas Ivone Sadd e Avenida Califórnia e sua margem esquerda está em processo de assoreamento.

O ponto PJ3 está localizado próximo ao conjunto de casa unifamiliares, recém-construídas e ocupadas, cerca de 120 metros de distância, observa-se nas margens a presença de resíduos sólidos.

O ponto PJ4 está localizado próximo à Avenida B, área com grande adensamento populacional e dista cerca de 10 metros das residências na Rua 06. Também apresenta resíduos sólidos nas suas margens, além de odor característico de efluente doméstico e sua margem esquerda está em processo de assoreamento. Este ponto dista aproximadamente 800 metros do deságue do córrego Josefa Gomes na Lagoa Feia.

\section{Determinações em Campo e Laboratório.}

Nos 12 pontos de amostragem foram realizadas em campo as determinações de $\mathrm{pH}$, Temperatura, Condutividade Elétrica e Totais de Sólidos Dissolvidos, utilizando um multiparâmetro portátil (Hach, série Sension 378) e Oxigênio Dissolvido por meio de Oxímetro Micropocessado portátil (modelo OMC-900). Para a coleta das amostras de água foram utilizados frascos de polietileno de $1 \mathrm{~L}$ previamente identificados, lavados com ácido nítrico 10\% v/v e com água obtida por sistema de purificação Milliq (resistividade de $18,2 \mathrm{M} \Omega \mathrm{cm}^{-1}$ a $25^{\circ} \mathrm{C}$ ). No momento da coleta, 
foram ambientados com a mesma água da amostra e acondicionadas sob refrigeração em caixas térmicas até a chegada nos Laboratório de Geoquímica da UnB e Laboratórios do Instituto Federal de Goiás. Turbidez; Cor e $\mathrm{NH}_{3}$ foram determinados por técnicas colorimétricas com leitura em espectrofotômetro (Hach modelo DR 2000).

As amostras de água coletadas foram divididas em duas frações de $50 \mathrm{~mL}$ filtradas para dois frascos de centrífuga de $50 \mathrm{~mL}$ utilizando membranas em ésteres de celulose com poro de 0,45 $\mu \mathrm{m}$ Milipore. Uma das frações foi acidificada com ácido nítrico suprapur Merck até $\mathrm{pH}<2$ para determinação de metais. A outra fração foi reservada para determinação dos ânions.

A determinação de $\mathrm{Na}$ e $\mathrm{K}$ foi realizada utilizando um Espectrofotômetro de Absorção Atômica (EAA), da marca Perkin Elmer, modelo Analyst 200, com fonte de excitação chama de aracetileno. As determinações de Fe e Al, foram realizadas por Espectrometria de Emissão Óptica com fonte de Plasma Indutivamente Acoplado (ICP/OES) marca Spectro, modelo SpectroflameFvmo3, utilizando nebulizador Meinhard.

Os ânions: $\mathrm{F}^{-}, \mathrm{Cl}^{-}, \mathrm{NO}_{3}{ }^{-}, \mathrm{PO}_{4}{ }^{3-}$ e $\mathrm{SO}_{4}{ }^{2-}$ foram determinados por cromatógrafo iônico (IC) com condutividade suprimida da marca Dionex, modelo ICS90. A alcalinidade foi determinada por método titulométrico com $\mathrm{H}_{2} \mathrm{SO}_{4}$ a $0,02 \mathrm{~N}$ padronizado com $\mathrm{NaOH} 0,05 \mathrm{~N}$, utilizando um titulador automático da marca Schott, modelo Titroline easy.

As metodologias utilizadas na determinação dos parâmetros foram baseadas no Standard Methods for the Examination of Water and Wastewater, edição da American Public Health Association (APHA), American Water Works Association (AWWA) e da Water Pollution Control Federation (WPCF). O controle de qualidade, nas análises laboratoriais, foi realizado por amostra padrão de referência do laboratório, amostra de controle (branco) e o balanço iônico conforme Logan (1965). As curvas analíticas do EAA, ICP e IC foram preparadas com soluções padrões de 1000 ppm da marca Vetec, a partir delas foram feitas as diluições necessárias para cada elemento.

Os dados obtidos com as determinações físico-químicas foram tratados com a aplicação da correlação de Spearman (R) entre os resultados, procedimento utilizado por Carmo et al (2005), Poudel et al (2013) e Zhang et al (2013). Esse é um método não paramétrico usado, nos casos em que os dados se apresentam dispersos, com alguns pontos da amostra bem distantes dos demais e quando esses não pertencem a uma escala de medida padrão, porém, possuem uma ordenação. 


\section{DISCUSSÃO TEÓRICA}

\section{Resultados das Determinações Físico-químicas}

Para as determinações físico-químicas foram utilizados 16 parâmetros. Os parâmetros Ferro Total (Fe) e Alumínio (Al), ficaram em todos os pontos, abaixo do Limite de Detecção LD > 0,3 (mg/L) e LD > 0,2 respectivamente. Os resultados do período chuvoso e seco estão apresentados na tabela 02.

Tabela 02: Parâmetros físico-químicos no período chuvoso e seco, córregos Bandeirinha e Josefa Gomes.

\begin{tabular}{|c|c|c|c|c|c|c|c|c|c|c|c|c|c|c|c|c|}
\hline \multicolumn{17}{|c|}{ CÓRREGO BANDEIRINHA - PARÂMETROS (Chuva) } \\
\hline \multirow{2}{*}{ Ponto } & \multirow{2}{*}{$\begin{array}{c}T \\
\stackrel{T}{\circ}\end{array}$} & \multirow{2}{*}{$\begin{array}{l}\text { Cor } \\
\text { UH }\end{array}$} & \multirow{2}{*}{$\begin{array}{c}\text { Turb } \\
\text { UT }\end{array}$} & \multirow{2}{*}{ pH } & \multirow{2}{*}{$\begin{array}{c}\text { C.E } \\
\mu \mathrm{s} / \mathrm{cm}\end{array}$} & TSD & O.D & Alcal & $\mathrm{NH}_{3}$ & $\mathrm{Na}$ & $\mathbf{K}$ & $\mathrm{SO}_{4}{ }^{2}$ & $\mathrm{PO}_{4}{ }^{3}$ & $\mathrm{NO}_{3}^{-}$ & $\mathrm{Cl}^{-}$ & $\mathbf{F}^{-}$ \\
\hline & & & & & & \multicolumn{11}{|c|}{$\mathrm{mg} / \mathrm{L}$} \\
\hline PB1 & 23 & 22 & 5 & 5,71 & 5 & 1,9 & 7,1 & 2,43 & $<\mathrm{LD}$ & 0,08 & 0,48 & $<\mathrm{LD}$ & $<\mathrm{LD}$ & 0,26 & 0,16 & 0,04 \\
\hline PB2 & 22,9 & 66 & 12 & 6,30 & 16,91 & 7,6 & 7,8 & 7,06 & 0,19 & 0,22 & 0,69 & 0,69 & 0,35 & $<$ LD & 0,25 & 0,03 \\
\hline PB3 & 21,5 & 127 & 26 & 5,96 & 12,17 & 5,3 & 8,9 & 7,06 & 0,27 & 0,21 & 0,56 & 0,71 & $<$ LD & 0,20 & 0,27 & $<L D$ \\
\hline PB4 & 21,8 & 78 & 16 & 6 & 13,45 & 5,9 & 8,2 & 7,06 & 0,16 & 0,23 & 0,51 & $<\mathrm{LD}$ & 2,51 & 0,23 & 0,27 & 0,03 \\
\hline PB5 & 22,5 & 57 & 13,60 & 7,44 & 112,90 & 53,7 & 9,3 & 34,19 & 0,14 & 0,63 & 2,12 & 0,65 & 0,52 & 0,50 & 0,46 & 0,04 \\
\hline PB6 & 23,7 & 53 & 12,30 & 7,46 & 149,30 & 71,2 & 8,7 & 45,44 & 0,13 & 0,65 & 2,41 & 1,88 & $<\mathrm{LD}$ & 0,49 & 0,47 & 0,09 \\
\hline PB7 & 27,5 & 238 & 73 & 7,51 & 99,30 & 47,1 & 9,5 & 33,72 & 0,17 & 0,97 & 2,36 & 1,06 & $<L D$ & 0,42 & 1,68 & 0,24 \\
\hline PB8 & 27,3 & 420 & 106 & 7,38 & 133 & 63,3 & 9,1 & 45,90 & 0,42 & 2,05 & 1,94 & 1,62 & $<\mathrm{LD}$ & 0,99 & 1,14 & 0,38 \\
\hline \multicolumn{17}{|c|}{ CÓRREGO BANDEIRINHA - PARÂMETROS (Seca) } \\
\hline PB1 & 23,8 & 18 & 5 & 5,4 & 4,95 & 1,8 & 6,9 & 12,35 & 0,25 & 0,12 & 0,39 & $<\mathrm{LD}$ & 1,5 & 0,49 & 0,35 & $<L D$ \\
\hline PB2 & 23,9 & 33 & 7 & 6,25 & 23,5 & 10,7 & 7,8 & 64,41 & 0,3 & 0,30 & 1,01 & $<L D$ & 0,85 & 0,31 & 0,78 & $<L D$ \\
\hline PB3 & 25,9 & 52 & 11 & 6,3 & 18,4 & 8,3 & 8,1 & 50,51 & 0,35 & 0,20 & 0,85 & $<\mathrm{LD}$ & 0,87 & 0,42 & 0,86 & 0,16 \\
\hline PB4 & 25,5 & 43 & 10 & 6,18 & 15,3 & 6,7 & 8,5 & 42,79 & 0,34 & 0,20 & 0,61 & $<\mathrm{LD}$ & $<L D$ & 0,39 & 0,83 & 0,09 \\
\hline PB5 & 24,5 & 15 & 4 & 7,78 & 165,9 & 79,2 & 9,5 & 47,84 & 0,30 & 0,74 & 2,70 & 0,75 & $<L D$ & 0,53 & 0,41 & $<L D$ \\
\hline PB6 & 25,7 & 5 & 3 & 7,96 & 191 & 91,3 & 8,3 & 52,89 & 0,28 & 0,71 & 3,03 & 0,59 & $<L D$ & 0,31 & 0,30 & 0,12 \\
\hline PB7 & 26,5 & 27 & 6 & 7,52 & 255 & 122,2 & 9,1 & 71,28 & 0,28 & 0,70 & 3,91 & 2,57 & 2,28 & 0,79 & 1,14 & 0,41 \\
\hline PB8 & 26,3 & 23 & 5 & 7,78 & 248 & 118,9 & 9,5 & 69,55 & 0,34 & 0,92 & 3,24 & 1,56 & 0,98 & 0,58 & 0,95 & 0,13 \\
\hline \multicolumn{17}{|c|}{ CÓRREGO JOSEFA GOMES - PARÂMETROS (Chuva) } \\
\hline \multirow{2}{*}{ Ponto } & \multirow{2}{*}{$\begin{array}{l}T \\
\text { oC }\end{array}$} & \multirow{2}{*}{$\begin{array}{l}\text { Cor } \\
\text { UH }\end{array}$} & \multirow{2}{*}{$\begin{array}{l}\text { Turb } \\
\text { UT }\end{array}$} & \multirow{2}{*}{$\mathrm{pH}$} & \multirow{2}{*}{$\begin{array}{c}\text { C.E } \\
\mu s / \mathrm{cm}\end{array}$} & TSD & O.D & Alcal & $\mathrm{NH}_{3}$ & $\mathrm{Na}$ & $\mathbf{K}$ & $\mathrm{SO}_{4}{ }^{2}$ & $\mathrm{PO}_{4}{ }^{3}$ & $\mathrm{NO}_{3}^{-}$ & $\mathrm{Cl}^{-}$ & $\mathbf{F}^{-}$ \\
\hline & & & & & & \multicolumn{11}{|c|}{$\mathrm{mg} / \mathrm{L}$} \\
\hline PJ1 & 22,6 & 49 & 11 & 6,45 & 57,10 & 26,80 & 7,2 & 15,66 & 0,11 & 3,65 & 0,70 & 1,12 & 1,29 & 0,32 & 1,37 & 0,04 \\
\hline PJ2 & 22,8 & 61 & 11,90 & 6,83 & 139,4 & 66,40 & 8,5 & 27,35 & 0,30 & 13,94 & 2,46 & 2,94 & $<$ LD & 11,50 & 6,21 & 0,13 \\
\hline PJ3 & 23,9 & 27 & 2,60 & 6,95 & 129,7 & 61,70 & 9,5 & 34,63 & 0,06 & 9,55 & 2,02 & 2,25 & $<L D$ & $<$ LD & 3,81 & 0,12 \\
\hline PJ4 & 22,9 & 37 & 4 & 7,17 & 129,0 & 61,40 & 6,7 & 35,07 & 0,09 & 9,01 & 1,79 & 1,76 & $<L D$ & 0,44 & 3,84 & 0,07 \\
\hline \multicolumn{17}{|c|}{ CÓRREGO JOSEFA GOMES - PARÂMETROS (Seca) } \\
\hline PJ1 & 25,60 & 8 & 2 & 6,26 & 41,10 & 19,10 & 8,1 & 10,34 & 0,19 & 3,88 & 0,23 & $<\mathrm{LD}$ & $<\mathrm{LD}$ & 0,93 & 2,59 & 0,09 \\
\hline PJ2 & 25,80 & 40 & 8 & 6,61 & 151,10 & 72,10 & 7,7 & 26,55 & 1,67 & 15,30 & 2,50 & 3,81 & 0,60 & 8,37 & 9,07 & 0,14 \\
\hline PJ3 & 24,90 & 43 & 9 & 6,84 & 138,60 & 66,00 & 9,1 & 31,94 & 0,29 & 13,75 & 0,89 & 0,92 & $<L D$ & 0,38 & 7,01 & $<L D$ \\
\hline PJ4 & 25,90 & 34 & 7 & 7,48 & 133,50 & 63,50 & 8,6 & 31,74 & 0,23 & 12,06 & 0,96 & $<L D$ & 1,25 & 0,51 & 6,90 & 0,24 \\
\hline
\end{tabular}

Obs.: Resultados abaixo do Limite de Deteç̧ão (<LD); UH = Unidade de Hasen; UT = Unidade de Turbidez.

No córrego Bandeirinha são perceptíveis a influência antrópica a partir dos pontos PB5 a PB8, estes localizados a jusante do núcleo urbano do município, apresentando as maiores alterações nos parâmetros avaliados tanto no período chuvoso quanto no período seco. No período seco destaca-se variação no $\mathrm{SO}_{4}{ }^{2}$ no $\mathrm{NO}_{3}{ }^{-}$e $\mathrm{Cl}^{-}$, que tem como possíveis fontes esgotos domésticos. Esta variação é melhor observada no período seco, principalmente para o $\mathrm{SO}_{4}{ }^{2}$, onde os valores obtidos do PB1 ao PB4 ficaram abaixo do limite de detecção.

A Condutividade Elétrica e os Totais de Sólidos Dissolvidos apresentam uma evolução nos valores ao longo da amostragem por serem cumulativos e diretamente proporcionais. Os maiores valores aferidos foram constados no período seco devido à concentração dos elementos. No período chuvoso, constatou-se maior carreamento do solo, alterando principalmente os parâmetros Cor e Turbidez.

A alcalinidade apresentou-se condizente com as características geológicas da região, que está situada na série Bambuí rica em carbonatos, os valores aferidos foram cumulativos, 
possivelmente oriundos do arraste de sedimentos e intemperismo nas margens das drenagens, nos pontos PB5 e PB6 a jusante do núcleo urbano do município, tanto no período chuvoso quanto no seco. O ponto PB1, correspondente a nascente do córrego, apresenta baixos valores nos parâmetros de qualidade. O O.D apresentou variação, diretamente ligada ao tipo do percurso nos pontos amostrados, ambiente lótico com a presença de corredeira, decorrente da geomorfologia local, mesmo com as evidentes contribuições de efluentes domésticos, este parâmetro apresentou pouca variação.

As análises evidenciam que os pontos amostrados no córrego Bandeirinha, estão sujeitos a poucas alterações na qualidade da água, pelos parâmetros físico-químicos determinados. As principais alterações nos parâmetros avaliados ocorrem à jusante do núcleo urbano do município, que dista cerca de $5 \mathrm{~km}$ do tributário mais próximo do córrego Bandeirinha, indicando a influência direta da área urbana sobre uma drenagem predominantemente inserida em área rural.

No córrego Josefa Gomes não foi verificada alterações significativas no pH permanecendo neutro a levemente alcalino. Assim como no córrego Bandeirinha, percebe-se no período chuvoso maiores valores para os parâmetros Cor e Turbidez, sendo reduzidos no período seco, quanto aos demais parâmetros apresentam valores aferidos maiores devido à concentração dos elementos.

Os parâmetros avaliados tiveram os maiores valores aferidos no ponto PJ2, localizado no final do trecho retificado, que recebe contribuição da drenagem superficial da Avenida Califórnia. Neste ponto foi verificada a presença de $\mathrm{NH}_{3}(0,30 \mathrm{mg} / \mathrm{L})$ no período chuvoso e concentração maior no período seco $(1,67 \mathrm{mg} / \mathrm{L})$, além dos maiores valores para $\mathrm{SO}_{4}{ }^{2-}, \mathrm{NO}_{3}{ }^{-}$e $\mathrm{Cl}^{-}$, tanto no período chuvoso quanto no período seco, indicando a contribuição de lançamento de efluentes domésticos. Consequentemente este ponto apresentou o menor valor para o Oxigênio Dissolvido - O.D (7,7 $\mathrm{mg} / \mathrm{L})$ no período seco.

No ponto PJ1, foi identificada a presença de $\mathrm{PO}_{4}{ }^{3}(1,29 \mathrm{mg} / \mathrm{L})$ no período chuvoso, possivelmente oriundo de adubos e preparo do solo, no processo de plantio e recuperação desta área no parque Mata da Bica, sendo esse valor registrado o maior entre os pontos de amostragem.

As figuras 3 e 4 apresentam os gráficos com a distribuição dos parâmetros físico-químicos nos córregos Bandeirinha e Josefa Gomes. Os parâmetros estão agrupados em A: Temperatura, Cor, Turbidez, pH, C.E, TSD, O.D e Alcalinidade nos períodos chuvoso e seco; grupo B: $\mathrm{NH}_{3}$; $\mathrm{Na}$, $\mathrm{K}, \mathrm{SO}_{4}{ }^{2-}, \mathrm{PO}_{4}{ }^{3-}, \mathrm{NO}_{3}^{-}, \mathrm{Cl}^{-}, \mathrm{F}^{-}$nos períodos chuvoso e seco. 

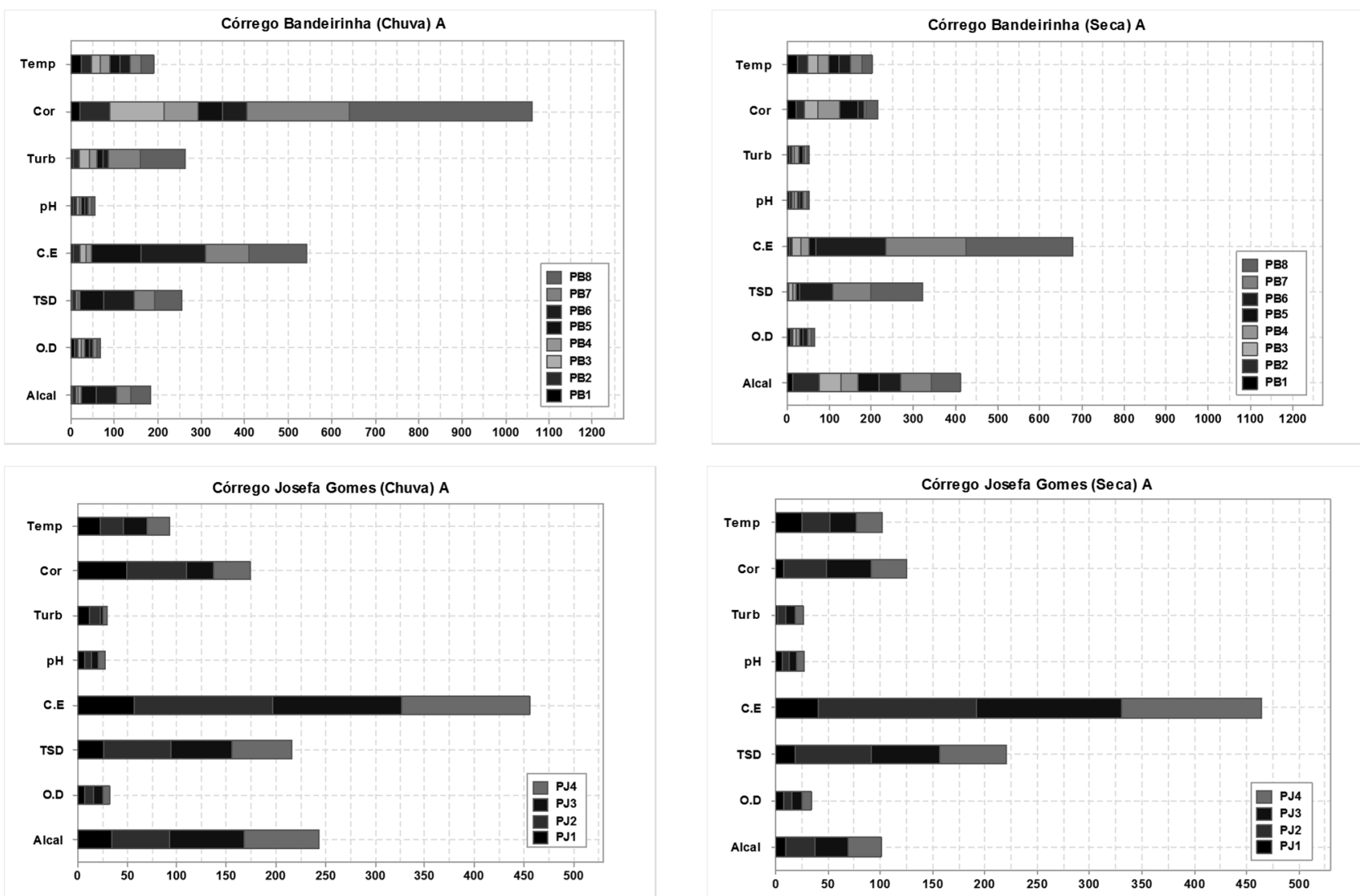

Figura 3: Distribuição dos parâmetros físico-químicos do grupo A (Temperatura, Cor, Turbidez, pH, C.E, TSD, O.D e Alcalinidade), córrego Bandeirinha e Josefa Gomes, períodos de chuva e seca.
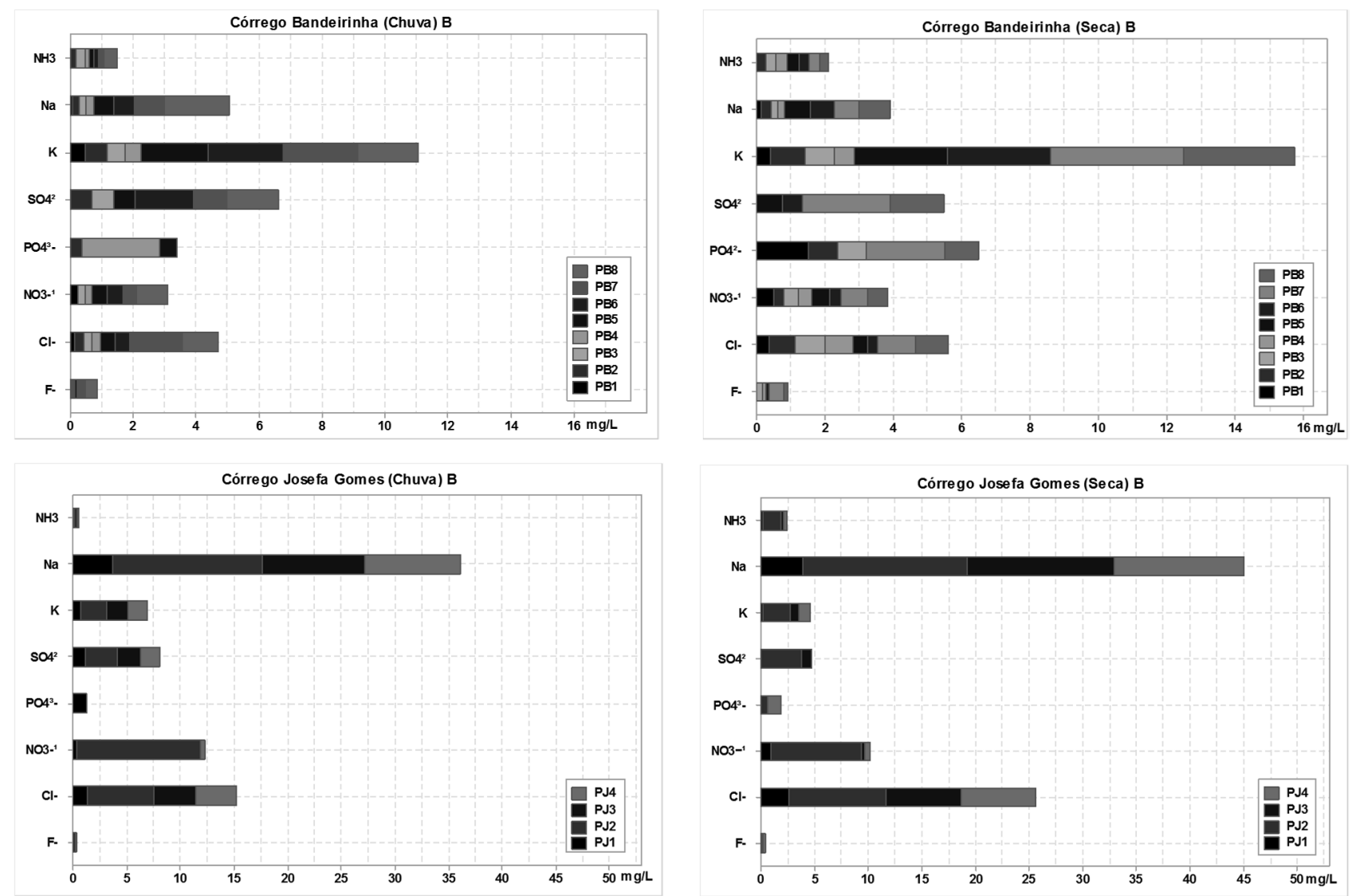

Figura 4: Distribuição dos parâmetros físico-químicos do grupo $\mathrm{B}\left(\mathrm{NH}_{3} ; \mathrm{Na}, \mathrm{K}, \mathrm{SO}_{4}{ }^{2}, \mathrm{PO}_{4}{ }^{3}, \mathrm{NO}_{3}{ }^{-1}, \mathrm{Cl}^{-}, \mathrm{F}^{-}\right)$, córrego Bandeirinha e Josefa Gomes, períodos de chuva e seca. 
Os gráficos expressam a distribuição proporcional dos parâmetros de qualidade da água aferidos entre os pontos de amostragem, evidenciando a diferença entre o período chuvoso e seco. A diferença entre os valores aferidos para Cor e Turbidez no córrego Bandeirinha, durante o período chuvoso e seco é mais evidente que no córrego Josefa Gomes, este fato pode ser explicado pelo ordenamento das drenagens. O córrego Bandeirinha possui uma rede de drenagem mais densa, portanto no período chuvoso a contribuição de materiais que alteram estes parâmetros é maior. É perceptível nos gráficos a concentração dos elementos no período seco tanto para o córrego Bandeirinha quanto para o córrego Josefa Gomes, esta última drenagem por estar completamente inserida em área urbana os valores aferidos para os parâmetros agrupados em $\mathrm{B}\left(\mathrm{NH}_{3} ; \mathrm{Na}, \mathrm{K}, \mathrm{SO}_{4}{ }^{2}\right.$, $\mathrm{PO}_{4}^{3-}, \mathrm{NO}_{3}^{-}, \mathrm{Cl}^{-}, \mathrm{F}^{-}$), são maiores e mais concentrados no período seco, destacando a influência das atividades antrópicas.

Pires (2012) realizou a análise dos parâmetros físico-químicos com amostragens no córrego Josefa Gomes (Cabeceira do Rio Preto) durante os períodos chuvoso e seco da região. Os parâmetros $\mathrm{NH}_{3} \mathrm{NO}_{3}^{-;} \mathrm{Cl}^{-}$; Na; apresentaram variação semelhante nos pontos amostrados nas áreas próximos dos pontos PJ1 e PJ2.

O PJ2 é ponto coincidente com o P2 aferido por Pires (2012), neste ponto a autora destaca que $\mathrm{NH}_{3}$ foi detectado apenas no P2 durante coleta de agosto de 2012, referente ao período seco da região. $\mathrm{O} \mathrm{NO}_{3}{ }^{-}$, foi o que apresentou maiores concentrações dos compostos nitrogenados 13,84 $\mathrm{mg} / \mathrm{L}$ em maio 2012. As concentrações dos compostos nitrogenados diminuem ao longo do corpo hídrico e esta redução pode estar associada ao crescimento de plantas aquáticas que utilizam esses compostos químicos incorporando em sua biomassa. Para o $\mathrm{Na}$ as concentrações variaram de 1,89 a $16,21 \mathrm{mg} / \mathrm{L}$, apresentando maior valor em P2 durante o período seco. Para o $\mathrm{Cl}^{-}$as concentrações variaram de 1,19 a 5,05 mg/L, apresentando maior valor em P2 também durante o período seco. Considerando o trabalho apresentado por Pires (2012), é evidente que no ponto P2, que coincide com a área do ponto PJ2, foi detectado valores expressivos indicando a contaminação por despejo de efluente doméstico.

No córrego Josefa Gomes é visível a ausência da vegetação ciliar, onde grande parte das formações vegetais foi removida para propiciar, inicialmente, a prática da agropecuária e, posteriormente, dar lugar à expansão urbana do município. É possível verificar que ao longo do córrego há lançamentos de efluentes, ocupações no fundo de vale, lançamento de resíduos sólidos, desenvolvimento de processos erosivos, assoreamentos, dentre outros impactos, intensificados pelos processos de uso e ocupação do solo na área urbana.

\section{Correlações}

Os resultados das determinações físico-químicas foram tratados por meio da correlação de Spearman e são apresentados nas tabelas 3 e 4, para os períodos chuvoso e seco dos córregos Bandeirinha e Josefa Gomes. 
Tabela 3: Matriz de correlação de Spearman entre parâmetros físico-químicos, nas águas do córrego Bandeirinha, período chuvoso e seco. Apenas correlações com significância $p<0,05$

\begin{tabular}{|c|c|c|c|c|c|c|c|c|c|c|c|c|c|c|c|c|c|}
\hline & Época* & Temp & Cor & Turb & $\mathrm{pH}$ & C.E & TSD & O.D & Alcal & $\mathrm{NH}_{3}$ & $\mathrm{Na}$ & $\mathbf{K}$ & $\mathrm{SO}_{4}{ }^{2}$ & $\mathrm{PO}_{4}{ }^{--}$ & $\mathrm{NO}_{3}^{-}$ & $\mathrm{Cl}^{-}$ & $F^{-}$ \\
\hline \multirow{2}{*}{ Temp } & C & 1 & & & & & & & & & & & & & & & \\
\hline & $\mathrm{s}$ & 1 & & & & & & & & & & & & & & & \\
\hline \multirow{2}{*}{ Cor } & c & - & 1 & & & & & & & & & & & & & & \\
\hline & $\mathrm{s}$ & - & 1 & & & & & & & & & & & & & & \\
\hline \multirow{2}{*}{ Turb } & c & - & 0,92 & 1 & & & & & & & & & & & & & \\
\hline & $s$ & - & 0,99 & 1 & & & & & & & & & & & & & \\
\hline \multirow{2}{*}{$\mathrm{pH}$} & c & - & - & - & 1 & & & & & & & & & & & & \\
\hline & $\mathrm{s}$ & 0,85 & - & - & 1 & & & & & & & & & & & & \\
\hline \multirow{2}{*}{ C.E } & $c$ & - & - & - & 0,83 & 1 & & & & & & & & & & & \\
\hline & $\mathrm{s}$ & 0,92 & - & - & 0,90 & 1 & & & & & & & & & & & \\
\hline \multirow{2}{*}{ TSD } & c & - & - & - & 0,83 & 1 & 1 & & & & & & & & & & \\
\hline & $\mathrm{s}$ & 0,92 & - & - & 0,90 & 1 & 1 & & & & & & & & & & \\
\hline \multirow{2}{*}{ O.D } & c & - & - & 0,76 & 0,71 & - & - & 1 & & & & & & & & & \\
\hline & $\mathrm{s}$ & - & - & - & 0,73 & 0,73 & 0,73 & 1 & & & & & & & & & \\
\hline \multirow{2}{*}{ Alcal } & c & - & - & - & 0,75 & 0,95 & 0,95 & - & 1 & & & & & & & & \\
\hline & $\mathrm{s}$ & 0,71 & - & - & - & - & - & - & 1 & & & & & & & & \\
\hline \multirow{2}{*}{$\mathrm{NH}_{3}$} & c & - & 0,88 & 0,71 & - & - & - & - & - & 1 & & & & & & & \\
\hline & $\mathrm{s}$ & - & - & - & - & - & - & - & - & 1 & & & & & & & \\
\hline \multirow{2}{*}{$\mathrm{Na}$} & $c$ & - & - & - & 0,83 & 0,85 & 0,85 & 0,71 & 0,90 & - & 1 & & & & & & \\
\hline & $\mathrm{s}$ & - & - & - & - & - & - & 0,77 & - & - & 1 & & & & & & \\
\hline \multirow{2}{*}{ K } & c & - & - & - & 0,95 & 0,88 & 0,88 & - & 0,80 & - & 0,76 & 1 & & & & & \\
\hline & $s$ & 0,73 & - & - & - & 0,71 & 0,71 & - & 0,88 & - & 0,82 & 1 & & & & & \\
\hline \multirow{2}{*}{$\mathrm{SO}_{4}^{2}$} & c & - & - & - & - & 0,74 & 0,74 & - & 0,76 & - & - & 0,77 & 1 & & & & \\
\hline & s & 0,80 & - & - & - & - & - & - & 0,80 & - & - & 0,80 & 1 & & & & \\
\hline \multirow{2}{*}{$\mathrm{PO}_{4}^{3-}$} & c & - & - & - & - & - & - & - & - & - & - & - & - & 1 & & & \\
\hline & $\mathrm{s}$ & - & - & - & 0,70 & - & - & - & - & - & - & - & 1 & 1 & & & \\
\hline \multirow{2}{*}{$\mathrm{NO}_{3}{ }^{-1}$} & c & - & - & - & - & 0,71 & 0,71 & - & 0,80 & - & 0,73 & - & - & - & 1 & & \\
\hline & $\mathrm{s}$ & - & - & - & - & - & - & - & - & - & - & - & 1 & 0,90 & 1 & & \\
\hline \multirow{2}{*}{$\mathrm{Cl}^{-}$} & c & - & - & 0,75 & 0,85 & 0,75 & 0,75 & 0,86 & 0,83 & - & 0,93 & 0,80 & 0,72 & - & - & 1 & \\
\hline & $s$ & 0,73 & - & - & - & - & - & - & - & - & - & - & 1 & - & - & 1 & \\
\hline \multirow{2}{*}{$F^{-}$} & c & 0,91 & - & - & - & - & - & - & 0,70 & - & 0,80 & - & - & - & 0,83 & 0,73 & 1 \\
\hline & $\mathrm{s}$ & 0,90 & - & - & - & - & - & - & 0,70 & - & - & 0,70 & 1 & - & 0,80 & 0,80 & 1 \\
\hline
\end{tabular}

São apresentados os resultados das correlações $\geq 0,70{ }^{*} \mathrm{C}=$ época de chuva; $\mathrm{s}=$ época de seca

Tabela 4: Matriz de correlação de Spearman entre parâmetros físico-químicos, nas águas do córrego Josefa Gomes, período chuvoso e seco. Apenas correlações com significância $p<0,05$

\begin{tabular}{|c|c|c|c|c|c|c|c|c|c|c|c|c|c|c|c|c|c|}
\hline & Época* & Temp & Cor & Turb & $\mathrm{pH}$ & C.E & TSD & O.D & Alcal & $\mathbf{N H}_{3}$ & $\mathrm{Na}$ & $\mathrm{K}$ & $\mathrm{SO}_{4}{ }^{2}$ & $\mathrm{PO}_{4}{ }^{3-}$ & $\mathrm{NO}_{3}{ }^{-}$ & $\mathrm{Cl}^{-}$ & $\mathrm{F}^{-}$ \\
\hline \multirow{2}{*}{ Temp } & C & 1 & & & & & & & & & & & & & & & \\
\hline & $\mathrm{s}$ & 1 & & & & & & & & & & & & & & & \\
\hline \multirow{2}{*}{ Cor } & c & - & 1 & & & & & & & & & & & & & & \\
\hline & $\mathrm{s}$ & - & 1 & & & & & & & & & & & & & & \\
\hline \multirow{2}{*}{ Turb } & c & - & 1 & 1 & & & & & & & & & & & & & \\
\hline & $\mathrm{s}$ & - & 1 & 1 & & & & & & & & & & & & & \\
\hline \multirow[t]{2}{*}{ pH } & c & 0,80 & - & - & 1 & & & & & & & & & & & & \\
\hline & $\mathrm{s}$ & - & - & - & 1 & & & & & & & & & & & & \\
\hline C.E & s & - & 0,80 & - & - & $\begin{array}{l}1 \\
1\end{array}$ & & & & & & & & & & & \\
\hline \multirow{2}{*}{ TSD } & c & - & - & - & - & 1 & 1 & & & & & & & & & & \\
\hline & $\mathrm{s}$ & - & 0,80 & 0,80 & - & 1 & 1 & & & & & & & & & & \\
\hline \multirow{2}{*}{ O.D } & c & - & - & - & - & - & - & 1 & & & & & & & & & \\
\hline & s & - & - & - & - & $\begin{array}{ll}- & \text { r }\end{array}$ & - & 1 & & & & & & & & & \\
\hline \multirow{2}{*}{ Alcal } & c & 0,80 & - & - & 1 & - & - & - & 1 & & & & & & & & \\
\hline & $\mathrm{s}$ & - & 0,80 & 0,80 & 0,80 & - & - & 0,80 & 1 & & & & & & & & \\
\hline \multirow{2}{*}{$\mathrm{NH}_{3}$} & C & - & - & 1 & - & - & - & - & - & 1 & & & & & & & \\
\hline & s & - & 0,80 & 0,80 & - & 1 & 1 & - & - & 1 & & & & & & & \\
\hline \multirow{2}{*}{$\mathrm{Na}$} & C & - & - & - & - & 1 & 1 & - & - & - & 1 & & & & & & \\
\hline & $s$ & - & 0,80 & 0,80 & - & 1 & 1 & - & - & 1 & 1 & & & & & & \\
\hline \multirow[t]{2}{*}{ K } & C & - & - & - & - & 1 & 1 & - & - & - & 1 & 1 & & & & & \\
\hline & $\mathrm{s}$ & - & - & - & - & 0,80 & 0,80 & - & - & 0,80 & 0,80 & 1 & & & & & \\
\hline \multirow{2}{*}{$\mathrm{SO}_{4}^{2}$} & C & - & - & - & 1 & - & 1 & - & - & - & 1 & 1 & 1 & & & & \\
\hline & S & 1 & - & $\begin{array}{l}- \\
-\end{array}$ & - & 1 & 1 & - & - & 1 & 1 & 1 & 1 & & & & \\
\hline $\mathrm{PO}_{4}^{3-}$ & $\begin{array}{l}\mathrm{C} \\
\mathrm{s}\end{array}$ & $\overline{1}$ & - & - & $\begin{array}{l}- \\
-\end{array}$ & - & - & $\overline{1}$ & $\overline{1}$ & - & - & - & - & $\begin{array}{l}1 \\
1\end{array}$ & & & \\
\hline \multirow{2}{*}{$\mathrm{NO}_{3}{ }^{-1}$} & c & - & 0,80 & 0,80 & - & - & - & - & - & 0,80 & - & - & - & - & 1 & & \\
\hline & $\mathrm{s}$ & - & - & - & - & - & - & - & - & - & - & - & 1 & - & 1 & & \\
\hline \multirow{2}{*}{$\mathrm{Cl}^{-}$} & c & - & - & - & - & 0,80 & 0,80 & - & - & - & 0,80 & 0,80 & 0,80 & - & 0,80 & 1 & \\
\hline & $\mathrm{s}$ & - & 0,80 & 0,80 & - & 1 & 1 & - & - & 1 & 1 & 0,80 & 1 & - & - & 1 & \\
\hline \multirow{2}{*}{$F^{-}$} & c & - & - & - & 1 & 1 & 1 & - & - & - & 1 & 1 & 1 & - & - & 0,80 & 1 \\
\hline & $\mathrm{s}$ & 1 & - & - & - & - & - & - & 1 & - & - & - & - & - & - & - & 1 \\
\hline
\end{tabular}

São apresentados os resultados das correlações $\geq 0,70{ }^{*} \mathrm{C}=$ época de chuva; $\mathrm{s}=$ época de seca. 
Dentre as correlações dos parâmetros avaliados no período chuvoso e seco, os TSD e C.E por serem diretamente proporcionais apresentam o mesmo comportamento no córrego Bandeirinha e Josefa Gomes ao se correlacionarem com os parâmetros: $\mathrm{HCO}_{3}{ }^{-} \mathrm{NH}_{3} \mathrm{Na} \mathrm{K} \mathrm{SO}{ }_{4}^{2} \mathrm{NO}_{3}{ }^{-1} \mathrm{Cl}^{-} \mathrm{F}^{-}$, estas correlações são mais fortes no período de seca, devido à concentração dos elementos na água. As fortes correlações entre $\mathrm{NH}_{3}, \mathrm{Na}, \mathrm{K}, \mathrm{SO}_{4}{ }^{2-}, \mathrm{NO}_{3}{ }^{-} \mathrm{Cl}^{-} \mathrm{F}^{-}$nos dois períodos, em ambas as drenagens sugerem a contribuição de atividades antrópicas, tanto na área urbana quanto rural do município.

Os parâmetros Cor e Turbidez apresentam forte correlação no período chuvoso, por estarem diretamente ligados à quantidade de materiais suspensos na água, carreados nesse período. Os mesmos parâmetros não apresentam forte correlação no período seco. Percebe-se também que Cor e Turbidez possui comportamento diferente no córrego Josefa Gomes, com fortes correlações com os íons $\mathrm{HCO}_{3}{ }^{-}, \mathrm{NH}_{3}, \mathrm{Na}, \mathrm{Cl}^{-}$, apenas na época seca, indicando a possível contribuição da área urbana para estes parâmetros na época seca.

$\mathrm{O}$ pH apresentou comportamento diferente entre as duas drenagens em relação à correlação dos elementos. Percebe-se que no córrego Bandeirinha, o pH teve correlações com C.E, TSD, O.D, $\mathrm{HCO}_{3}{ }^{-}, \mathrm{Na}, \mathrm{K}, \mathrm{SO}_{4}{ }^{2-}, \mathrm{NO}_{3}{ }^{-}, \mathrm{Cl}^{-}, \mathrm{F}^{-}$, mais fortes no período chuvoso, indicando que a quantidade de elementos nesta drenagem ocorre mais na forma solúvel em água levemente alcalina.

No córrego Josefa Gomes o pH somente se correlacionou com o $\mathrm{HCO}_{3}{ }^{-}, \mathrm{SO}_{4}{ }^{2-}, \mathrm{F}^{-}$nesta drenagem, deve-se considerar que o aporte dos elementos é maior nas duas épocas consequência da área urbana. Maiores concentrações dos elementos podem ter reduzido a correlação do pH com os demais elementos na água. Enquanto que no córrego Bandeirinha o aporte dos elementos é menor, e decorre principalmente dos processos de intemperismo das rochas e margens da drenagem, consequência das características geológicas da região.

A $\mathrm{NH}_{3}$ apresentou fortes correlações no córrego Josefa Gomes, para o período seco com $\mathrm{Na}, \mathrm{K}, \mathrm{SO}_{4}{ }^{2-}, \mathrm{NO}_{3}{ }^{-}, \mathrm{Cl}^{-}$, assim como a $\mathrm{NH}_{3}$ estes elementos estão presentes em lançamentos de efluentes domésticos. Destaca-se também a forte correlação do $\mathrm{NH}_{3}$ com os C.E e TSD no período seco $(r=1)$, correlação esta que não ocorre no período chuvoso, indicando a concentração dos elementos no período seco e a possibilidade de uma fonte de lançamento de efluentes domésticos contínua, que é diluída no período chuvoso e se destaca no período seco. No córrego Bandeirinha a $\mathrm{NH}_{3}$, não apresentou correlação com nenhum dos demais elementos.

As correlações abaixo da significância entre a Temperatura e o O.D, que ocorreram nas duas drenagens, indicam que tanto para o córrego Bandeirinha quanto para o córrego Josefa Gomes, a morfologia das drenagens tem uma maior influência sobre a quantidade de O.D do que a temperatura média da região. 
$\mathrm{O} \mathrm{SO}_{4}{ }^{2-}$ apresentou comportamento semelhante em relação à correlação nos dois córregos, tendo fortes correlações com Na, $\mathrm{K}, \mathrm{PO}_{4}{ }^{3-}, \mathrm{NO}_{3}{ }^{-}, \mathrm{Cl}^{-}, \mathrm{F}^{-}$, evidenciadas no período de seca, porém este decorre de origens diferentes. Para o córrego Bandeirinha o $\mathrm{SO}_{4}{ }^{2-}$, advém de fertilizantes e preparo do solo na área rural, enquanto no córrego Josefa Gomes é indicativo dos impactos gerados no ambiente urbano.

No período seco, observa-se mais claramente a forte correlação entre os parâmetros, do que no período chuvoso. Isso indica que a influência das atividades antrópicas é maior no período de seca como consequência da concentração dos elementos na água.

\section{CONCLUSÕES}

Os parâmetros analisados durante os períodos chuvoso e seco da região demonstram a variação da qualidade da água nos córregos Bandeirinha e Josefa Gomes, indicando a influência direta das atividades antrópicas. Deve-se ressaltar que as áreas dos pontos amostrados possuem passivos ambientais gerados pelas atividades antrópicas, que contribuem de forma significativa para as alterações na qualidade da água, seja por áreas de preservação permanente desprovidas de cobertura vegetal ou lançamentos de efluentes domésticos e resíduos sólidos.

O córrego Bandeirinha está inserido em área rural do município, mesmo com os impactos gerados pelas atividades agropastoris a avaliação da qualidade da água em contexto geral indica boa qualidade da água amostrada. Quanto ao córrego Josefa Gomes, inserido em ambiente urbano do município, os impactos gerados alteram a qualidade da água nesta drenagem, as variações nas aferições dos parâmetros indicam alteração de origem antrópica.

Em relação à Resolução CONAMA 357/2005 que determina os Valores Máximos e Mínimos Permitidos - VMP, para os parâmetros de qualidade da água superficial, deve-se destacar que no córrego Bandeirinha apenas Cor e Turbidez ficaram acima dos V.M.P nos pontos PB7 e PB8 durante o período chuvoso. Quanto ao córrego Josefa Gomes o ponto PJ2 apresentou aferição superior ou V.M.P para a $\mathrm{NH}_{3}(11,50 \mathrm{mg} / \mathrm{L})$.

Contudo a Resolução CONAMA 357/2005 não pode ser aplicada para a identificação dos processos de interação e impactos ambientais de origem antrópica. Quando utilizada a correlação entre os dados percebe-se a evolução destes impactos nas duas drenagens analisadas tanto em área rural quanto urbana. A continuidade destes processos, impulsionado pela expansão urbana da região do entorno de Brasília pode agravar os valores aferidos ultrapassando os V.M.P determinados pela Resolução CONAMA 357/2005.

O tratamento estatístico, com a análise não paramétrica de Spearman, auxiliou na identificação das correlações entre os parâmetros físico-químicos determinados, confirmando os resultados quanto à influência da urbanização e das atividades agropastoris. Nas duas drenagens 
avaliadas pode ser constatada em intensidade diversa alterações antrópicas, decorrentes dos diversos desajustes de planejamento urbanístico, socioeconômico e ambiental do município de Formosa, intensificados ao longo de sua história.

Compreender as relações entre os parâmetros de qualidade da água ajuda no gerenciamento e monitoramento de uma drenagem superficial de forma mais eficaz, para que possa ter seus diversos usos resguardados; auxilia também na redução do número de parâmetros de qualidade da água para monitoramento.

Os dados gerados ajudam a identificar fatores associados com a variabilidade dos parâmetros de qualidade de água, além de subsidiar a implementação de medidas de conservação e proteção nas duas drenagens avaliadas, a elaboração e execução de políticas públicas de gestão ambiental do município e contribuem com a geração de informações acerca da qualidade da água superficial da região, que apresenta demanda de consumo crescente e constante.

\section{AGRADECIMENTOS}

Os autores agradecem aos técnicos, professores e alunos do Laboratório de Geoquímica do Instituto de Geociências da UnB, ao Instituto Federal de Educação Ciência e Tecnologia Goiás IFG, ao CNPq e a CAPES.

\section{REFERÊNCIAS}

APHA, AWWA, WPCF; Standard Methods for the Examination of Water and Wastewater, 20th Ed; Washington, 1999.

CARMO, M.S.; BOAVENTURA, G. R.; OLIVEIRA, E.C. Geoquímica das Águas da Bacia do Rio Descoberto, Química Nova, Brasília, v.28, n.4, p.565-574, 2005.

CHAVES, J; GUIMARÃES E.M; SANO, E.E; Mapa Morfoestrutural da Região de Bezerra-Cabeceiras (GO) com Base em Geoprocessamento In X Simpósio Brasileiro de Geografia Física Aplicada, Anais, 2014.

CONSELHO NACIONAL DO MEIO AMBIENTE, Resolução CONAMA 357/05: Estabelece a classificação das águas, doces, salobras e salinas do Território Nacional. Brasília, 2005.

CYRIL. W; WENG. Q. Assessing Surface Water Quality and Its Relation with Urban Land Cover Changes in the Lake Calumet Area, Greater Chicago, Environmental Management, Indiana, v. 45, p.1096-1111, 2010. DOI: http://dx.doi.org/10.1007/s00267-010-9482-6.

GUIMARÃES E.M. Estudos de proveniência e diagênese, com ênfase na caracterização dos filossilicatos dos grupos Paranoá e Bambuí, na região de Bezerras-Cabeceiras, GO. Tese de doutoramento, Universidade de Brasília, 1997.

INSTITUTO BRASILEIRO DE GEOGRAFIA E ESTATístICA (IBGE), Censo Demográfico. Brasília, 2012.

LE A.H; TOKAI A; NAKAKUBO T; Applying value of information methods to prioritize elements for water quality management with an example of linear alkylbenzene sulfonate in the Yodo River, Japan.

Environment Systems and Decisions, Japan, v. 34, p.110-123, 2014.

DOI: http://dx.doi.org/10.1007/s10669-014-9490-9 
LOGAN, J; Interpretação de Análises Químicas da Água. US. Agency for International Development. Recife. 1965.

MAURO, C.A; DANTAS, M; ROSO, F.A. Geomorfologia da Folha SD23, Brasília. Levantamento de Recursos Naturais, v. 29, Projeto Radambrasil. Rio de Janeiro, 1982.

SANTOS, A.L.F; BORGES, L.O.S; BOAVENTURA, G.R; Indicadores de Qualidade dos Sedimentos do Ribeirão Piancó Anápolis - GO, e suas Implicações Ambientais. Goiás, Scientia Plena, v. 8, n.10, 2012.

PIRES, N.L; Caracterização da Qualidade da Água na Cabeceira do Rio Preto em Formosa-Go.

Trabalho de Conclusão do Curso de Química na Universidade Estadual de Goiás UEG, Formosa, 2012.

POUDEL D.D, LEE T, SRINIVASAN R, ABBASPOUR K, JEONG C.Y. Assessment of seasonal and spatial variation of surface water quality, identification of factors associated with water quality variability, and the modeling of critical nonpoint source pollution areas in an agricultural watershed. Journal Soil and Water Conservation Society, USA, v.68, n.3, p.155-171, 2013. DOI: http://dx.doi.org/10.2489/jswc.68.3.155

RODRIGUEZ, H.G; POPP, J; GBUR, E; PENNINGTON J. A. Stakeholder-Guided Collaborative Approach to Improve Water Quality in a Nutrient Surplus Watershed, Journal of Water Resource and Protection, USA, v 6, p.571-582, 2014. DOI: http://dx.doi.org/10.4236/jwarp.2014.66056

SERVIÇO GEOLÓGICO NACIONAL: CPRM. Programa Levantamentos Geológicos Básicos do Brasil: Folha SE.23. Brasília. Escala 1:100.000. CPRM/DNPM, Brasília, DF. 2004.

STRAHLER, A.N, Physical geography. 4º edition. New York/London/Sidney/Toronto: John Willey e Sons, 1957.

SPERLING, M.V. Estudos e modelagem da qualidade da água de rios. Belo Horizonte: DESA, 2007.

ZHANG Z; CHEN .Y, WANG .P, SHUAI .J, TAO .F, SHI .P. River discharge, land use change, and surface water quality inthe Xiangjiang River, Hydrological Processes, China, v.28, n.13, p.4130-4140, 2014. DOI: http://dx.doi.org/10.1002/hyp.9938 


\title{
ESTUDO DOS SEDIMENTOS DA CORRENTE EM DRENAGENS INSERIDAS NA ÁREA RURAL E NA ÁREA URBANA DO MUNICÍPIO DE FORMOSA-GO
}

\author{
Sandro Morais Pimenta, Geraldo Resende Boaventura, Tiago Godol Ribeiro, Alfredo Palau Peña
}

Resumo

As análises de sedimentos de corrente envolvem o estudo da distribuição, migração e reaçōes químicas dos elementos nos recursos hídricos. Essas análises geram informações acerca das alterações de ordem natural ou antrópica e podem ser associadas às análises físico-químicas de qualidade da água. Este trabalho teve por objetivo o estudo dos sedimentos de corrente ea observação dos resultados entre os córregos Bandeirinha, situado na área rural, e o córrego Josefa Gomes, inserido no núcleo urbano do município de Formosa-Go. Foram determinados 12 pontos de amostragem de sedimentos, aplicando os seguintes métodos: fracionamento granulométrico, aferição dos sólidos voláteis, determinação de elementos maiores e traços e análise por Difratometria de Raios-X para determinação da composição mineral. Todos os procedimentos foram realizados no Laboratório de Geoquímica da UnB, no Laboratório de Raios-X do Instituto de Geociências da UnB, no Laboratório de Geotecnia do Instituto Federal de Goiás - IFG, e no Laboratório da Campo Ltda. logo após a recepção das amostras. Constatou-se a influência da geologia nas avaliaçöes das condições geoquimicas dos sedimentos de corrente no córrego Bandeirinha e a evidente influência antrópica do núcleo urbano nos sedimentos do córrego Josefa Gomes. Os resultados podem ser associados às análises fisico-químicas e avaliaçōes por bioindicadores de qualidade de água, que auxiliam na identificaçăo das alteraçöes derivadas das atividades antrópicas, ou de origem natural no ambiente rural e urbano, e suas consequências a médio e longo prazo, além de contribuir com a geração de dados e caracterizaçăo geoquímica da região.

Palavras-chave

Elementos Maiores e Traços; Sedimentos; Recursos Hidricos. 


\title{
ESTUDO DOS SEDIMENTOS DE CORRENTE EM DRENAGENS INSERIDAS NA ÁREA RURAL E ÁREA URBANA DO MUNICÍPIO DE FORMOSA-GO.
}

\author{
STUDY OF SEDIMENTS IN CURRENT DRAINS ENTERED IN RURAL AND URBAN AREA \\ IN FORMOSA-GO MUNICIPALITY.
}

\begin{abstract}
RESUMO
As análises de sedimentos de corrente envolvem o estudo da distribuição, migração e reações químicas dos elementos nos recursos hídricos. Essas análises geram informações acerca das alterações de ordem natural ou antrópica e podem ser associadas às análises físico-químicas de qualidade da água. Este trabalho teve por objetivo o estudo dos sedimentos de corrente e a observação dos resultados entre os córregos Bandeirinha, situado na área rural, e o córrego Josefa Gomes, inserido no núcleo urbano do município de Formosa-GO. Foram determinados 12 pontos de amostragem de sedimentos, aplicando os seguintes métodos: fracionamento granulométrico, aferição dos sólidos voláteis, determinação de elementos maiores e traços e análise por Difratometria de Raios$\mathrm{X}$ para determinação da composição mineral. Todos os procedimentos foram realizados no Laboratório de Geoquímica da UnB, no Laboratório de Raios-X do Instituto de Geociências da UnB, no Laboratório de Geotecnia do Instituto Federal de Goiás - IFG, e no Laboratório da Campo Ltda., logo após a recepção das amostras. Constatou-se a influência da geologia nas avaliações das condições geoquímicas dos sedimentos de corrente no córrego Bandeirinha e a evidente influência antrópica do núcleo urbano nos sedimentos do córrego Josefa Gomes. Os resultados podem ser associados às análises físico-químicas e avaliações por bioindicadores de qualidade de água, que auxiliam na identificação das alterações derivadas das atividades antrópicas, ou de origem natural no ambiente rural e urbano, e suas consequências a médio e longo prazo, além de contribuir com a geração de dados e caracterização geoquímica da região.
\end{abstract}

Palavras-chave: Elementos maiores e traços, Sedimentos, Recursos Hídricos.

\begin{abstract}
The stream sediments analysis involves the study of the distribution, migration and chemical reactions of the elements on water resources. These analyzes generate information about changes of natural and anthropic order and can be attached to physicochemical analysis of water quality. This study aimed to the study of stream sediments and observation of the results between Bandeirinha streams located in a rural area and the stream Josefa Gomes, inserted in the urban core of the city of Formosa GO. Were determined 12 sampling points in sediments, applying the following methods: grain size fractions, measurement of volatile solids, determination of major and trace elements and analysis by diffraction of X-rays to determine the mineral composition. All procedures were performed in Geochemistry Laboratory at UNB in the X-ray Laboratory of Geosciences Institute at UNB in the Geotechnical Laboratory of the Federal Institute of Goiás - IFG, and Campo Laboratory Ltd, on receipt of the samples. It was found the influence of geology in the evaluation of geochemical conditions of stream sediments in the stream Bandeirinha and the evident anthropogenic influence the urban core in stream sediments Josefa Gomes. The results can be linked to physical-chemical analysis and evaluation by bioindicators of water quality, and help identify the changes derived from human activities or natural origin in rural and urban environment, and the consequences in the medium and long term, and contribute to the generation of data and geochemical characterization of the region.
\end{abstract}

Keywords: Elements largest and traces, Sediments, Water Resources. 


\section{INTRODUÇÃO}

Os sedimentos de corrente são materiais não consolidados provenientes do intemperismo, dissolução das rochas, processos erosivos do solo e contribuições antrópicas, que refletem as alterações ambientais de ordem naturais e ou antrópica ocorridas em um recurso hídrico.

Carmo et al. (2005), destacaram que a distribuição de elementos químicos depende não somente das suas concentrações, mas também das reações físico-químicas nos ambientes, diretamente influenciadas por condições morfoclimáticas, intemperismo natural, geologia regional e ações antrópicas.

As amostras de sedimentos informam possíveis anomalias a montante do local da coleta, pois representam a integração de todos os processos que ocorrem no ecossistema aquático, e auxiliam para elucidar a poluição ambiental atribuída aos metais ou substâncias orgânicas (Boaventura e Moreira, 2003).

Maia et al. (2005) realizaram o estudo mineralógico dos sedimentos de fundo no lago Paranoá, em Brasília, utilizando técnicas de difratometria de raios-X. Os autores constataram que muitas informações sobre a geologia e a composição química de uma bacia de drenagem são registradas nos sedimentos de corrente.

Mulholland et al. (2012) utilizaram a determinação geoquímica para identificação e separação das influências de ordem antrópica ou geológica na composição dos sedimentos de corrente. Os autores identificaram os depósitos minerais e atividades de mineração como fontes de metais no sedimento. Para determinar a distribuição e o acúmulo, aplicaram técnicas de difratometria de raios$\mathrm{X}$ associadas à análise das amostras com a utilização da Espectrometria de Emissão Óptica com fonte de Plasma Indutivamente Acoplado (ICP/OES) e Espectrofotometria de Absorção Atômica (AAS).

Tanto em amostras de sedimento quanto em amostras de água é possível identificar a presença de metais de origem natural ou antrópica. Conforme Santos et al. (2012), diversos estudos em drenagens superficiais indicam como possível fonte dos elementos $\mathrm{Cu}, \mathrm{Fe}, \mathrm{Ni}, \mathrm{Al}, \mathrm{Cr}, \mathrm{Mn}, \mathrm{Zn}$ e $\mathrm{Cd}$, o uso e ocupação do solo, seja em área urbana ou rural. Em áreas urbanas a utilização de combustíveis, 
lubrificantes, produtos de limpeza, atividades industriais e outras são fontes antrópicas destes elementos. Nas áreas rurais os insumos utilizados nas atividades agropastoris auxiliam no aumento da produtividade em relação à área cultivada; contudo geram impactos ambientais no solo e nas drenagens superficiais, além da possiblidade de intoxicação das comunidades próximas por meio da ingestão progressiva destes produtos.

Carmo et al. (2003) aplicaram técnicas de ICP/OES e AAS, análise granulométrica e determinação do material volátil para identificar alterações geoquímicas nos sedimentos de corrente do rio Descoberto, no DF, e demostraram os efeitos de atividades antrópicas na região e a contribuição no processo de alteração geoquímica das águas na Bacia do Rio Descoberto.

O objetivo deste trabalho foi realizar o estudo dos sedimentos de corrente e analisar os resultados do córrego Bandeirinha situado em ambiente predominantemente rural, e o córrego Josefa Gomes, inserido no núcleo urbano do município de Formosa-GO. Assim como outros municípios do entorno de Brasília, a forma e a velocidade do processo de ocupação urbana em Formosa, impulsionado pela construção de Brasília, refletiram-se fortemente sobre os recursos naturais e o meio social.

A avaliação das condições geoquímicas dos sedimentos de corrente, nas duas drenagens, contribuirá com a geração de dados e caracterização geoquímica regional e auxiliará na determinação das possíveis contaminações provenientes das atividades antrópicas no ambiente rural e urbano do município de Formosa, inferindo sobre suas consequências a médio e longos prazos.

\section{MATERIAL E MÉTODOS}

\section{Área de Estudo}

As áreas selecionadas para o desenvolvimento da pesquisa foram os córregos Bandeirinha e Josefa Gomes, localizados no município de Formosa-GO. A escolha das duas drenagens para o desenvolvimento do estudo deu-se por possuírem características distintas, porém localizadas na mesma região. O município está localizado na microrregião do entorno de Brasília, cerca de 70 km da capital federal (Figura 1), possui uma população de 100.085 habitantes (IBGE, 2012). A 
agropecuária é atividade estruturante na economia de Formosa, principalmente a pecuária de corte e leite.

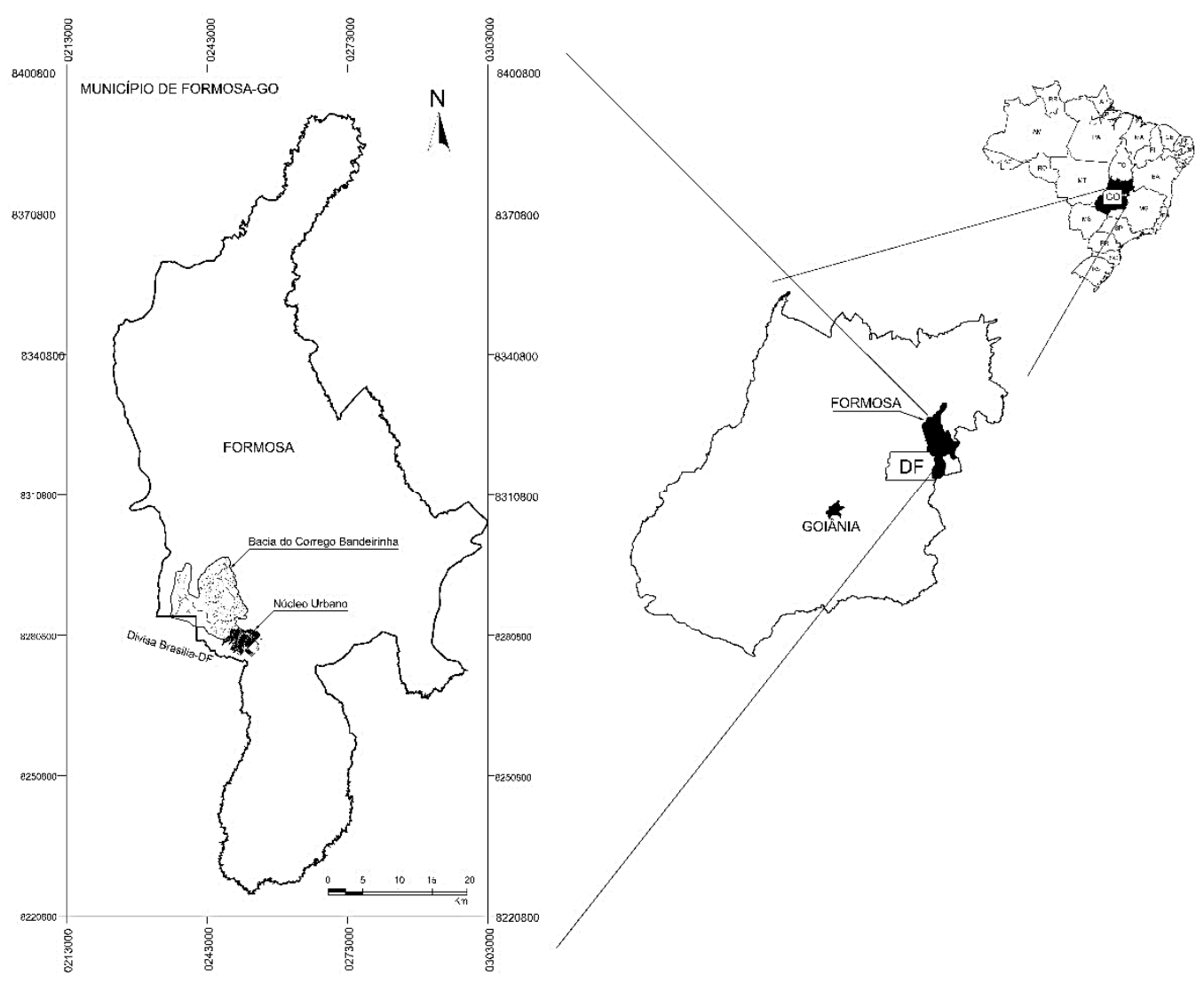

Figura 1: Localização do município de Formosa-GO. Fonte: IBGE 2012, Organização Final, Pimenta 2014.

A região do município de Formosa possui clima segundo a classificação de Kooeppen: Aw, definido por uma época seca, que corresponde ao outono e inverno nos meses de maio a setembro, e a outra úmida com chuvas torrenciais, correspondendo ao período de primavera e verão nos meses de outubro a abril. O período de seca apresenta estabilidade climática e reduzida precipitação. A distribuição pluviométrica segue o padrão típico da região Centro-Oeste do Brasil no domínio morfoclimático dos Cerrados, com precipitação média anual de $1.485 \mathrm{~mm}$ e temperatura média anual em torno de $21,5^{\circ} \mathrm{C}$.

Na carta geológica do Serviço Geológico do Brasil, folha SD 23 Brasília, elaborada por Souza et al. (2004), na região do município de Formosa há ocorrência de rochas do Proterozoico, representado pelo Grupo Paranoá, de idade mesoproterozoica e Grupo Bambuí, Subgrupo Paraopeba 
de idade neoproterozoica, coberturas Detrito-Lateríticas do Terciário-Quaternário e Aluviões recentes nas margens dos cursos de água.

Conforme Guimarães (1997), na região de Formosa-Bezerra-Cabeceiras, o Grupo Paranoá é exposto no centro de grandes anticlinais inversos de flancos falhados, podendo estar recoberto pelos diamictitos glaciais da Formação Jequitaí ou diretamente pelos carbonatos do Grupo Bambuí.

Por meio de estudos sedimentológicos, petrográficos e químicos das rochas dos grupos Paranoá e Bambuí, Guimarães (1997) aponta que as rochas de ambas as unidades se originaram em contextos tectônicos distintos e que os sedimentos são provenientes de rochas-fontes diferentes. As rochas do Grupo Paranoá são arenitos e pelitos formadas por sedimentos cratônicos, depositadas lentamente sobre uma bacia tectonicamente estável. As rochas terrígenas do Grupo Bambuí são mineralógica e texturalmente imaturas, tendo os sedimentos se acumulado em uma bacia sobre influência de processos colisionais.

O Grupo Paranoá é formado pelo empilhamento de quartzitos e pelitos, com participação menor de arcóseos, quartzitos glauconíticos e carbonatos, enquanto as rochas terrígenas do Grupo Bambuí são ricas em micas detríticas e argilominerais. Micas (muscovita e biotita) são alteradas diageneticamente para cloritas e ilitas ou têm composição fengítica. A composição e textura de cloritas ferrosas indicam substituição de minerais máficos ou representam o produto da evolução diagenética de esmectitas trioctaédricas (GUIMARÃES, 1997).

De acordo com a carta geológica do Serviço Geológico Nacional, elaborada por Souza et al. (2004), a região do córrego Bandeirinha no alto da sua bacia, correspondendo a áreas das nascentes (elevação de 1095 m), está situada em rochas do grupo Paranoá, nas regiões média e baixa da bacia no sentindo do deságue no Rio Paranã (elevação de $612 \mathrm{~m}$ ), onde predominam as rochas do grupo Bambuí. Enquanto o córrego Josefa Gomes está completamente inserido em rochas do grupo Paranoá, da nascente ao deságue, na Lagoa Feia.

Fundamentado no mapeamento geomorfológico da Folha SD 23 Brasília, elaborado por Mauro et al. (1982), a área de estudo se insere nos domínios dos Planaltos em Estruturas Sedimentares 
Concordantes. Esse domínio compreende a unidade geomorfológica Chapadas do Distrito Federal, integrante da região geomorfológica Planalto Goiás-Minas.

Chaves et al. (2014) destacam que a Região dos Planaltos de Goiás-Minas é formada pelas Chapadas do Distrito Federal e caracteriza-se por modelados constituídos principalmente por uma superfície de aplainamento degradada e retocada pela dissecação incipiente, produzida pelos Rios São Bartolomeu e Preto. A sudeste da cidade de Formosa, os topos tabulares do planalto são mantidos por couraças ferruginosas constituídas por fragmentos de rocha. No município é evidente a presença dos sistemas cársticos em rochas do Grupo Bambuí.

Faria (1995) descreveu que a Cobertura Detrito-Laterítica, presente na região, corresponde a uma superfície desenvolvida a partir de um processo de aplainamento e laterização de toda uma região que engloba o centro-oeste brasileiro. São caracterizadas por latossolos vermelhos amarronzados, estrutura indefinida e textura areno-argilosa. Os aluviões são caracterizados por sedimentos inconsolidados, dominantemente arenosos, representados por areias, com níveis de cascalhos e lentes de material silto-argiloso.

O córrego Bandeirinha é o manancial utilizado pelo sistema de abastecimento de água do município e está inserido em área predominantemente rural, com percurso de aproximadamente 42 km, direção Norte, desagua no Rio Paranã e pertence à bacia do Rio Tocantins. O córrego Josefa Gomes está completamente inserido em ambiente urbano, tem percurso de 7,5 km em direção sudoeste. Sua nascente localiza-se no parque municipal mata da bica, e parte do percurso é retificado em 1,5km. Após a retificação, o córrego Josefa Gomes percorre aproximadamente 6 km e desagua na Lagoa Feia. Em seguida à Lagoa Feia, o córrego é denominado de Rio Preto, percorrendo os Estados de Goiás, Distrito Federal e Minas, e pertencendo à bacia do Rio São Francisco.

\section{Amostragem}

Para a realização do estudo foram determinados oito pontos espacializados no córrego Bandeirinha, e quatro pontos no córrego Josefa Gomes (figura 2). A seleção dos pontos de 
amostragem deu-se considerando as atividades antrópicas ao longo da drenagem e a incidência de tributários. A amostragem ocorreu no primeiro semestre de 2013.

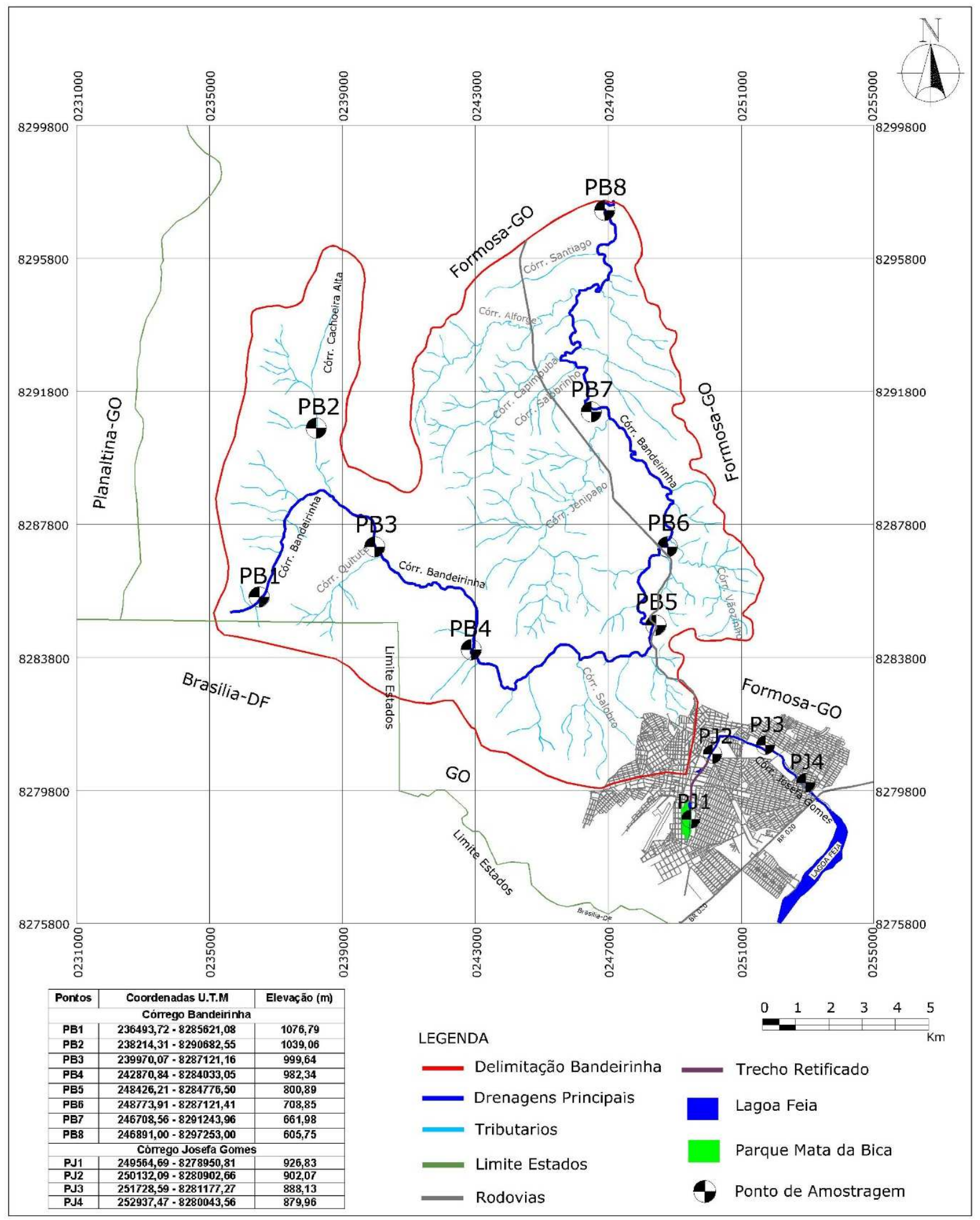

Figura 2: Pontos de amostragem córrego Bandeirinha e Josefa Gomes, Formosa-GO. Fonte: IBGE 2012, Organização Final, Pimenta 2014. 
Os oito pontos de amostragem no córrego Bandeirinha e os quatro pontos de amostragem no córrego Josefa Gomes seguem da nascente até o deságue das drenagens, O quadro 1 apresenta a localização e as considerações sobre o uso do solo no entorno dos pontos.

Quadro 1. Localização e descrição do uso do solo nos pontos de amostragem.

\begin{tabular}{|c|c|c|c|}
\hline \multicolumn{4}{|c|}{ Pontos Córrego Bandeirinha } \\
\hline PB & Coordenadas UTM & Elevação (m) & Uso e Ocupação \\
\hline PB1 & $236493-8285621$ & 1076,79 & $\begin{array}{l}\text { Cerca de } 300 \text { metros da nascente, presença de fazendas } \\
\text { com atividades agropastoris. }\end{array}$ \\
\hline PB2 & $238214-8290682$ & 1039,06 & $\begin{array}{l}\text { Tributário do córrego Bandeirinha, córrego Cachoeira } \\
\text { Alta, presença de pequena fazenda com produção de } \\
\text { hortaliças. }\end{array}$ \\
\hline PB3 & $239970-8287121$ & 999,64 & $\begin{array}{l}\text { Fazenda Asa Branca, área utilizada para a pecuária } \\
\text { extensiva, margens protegidas. }\end{array}$ \\
\hline PB4 & $242870-8284033$ & 982,34 & $\begin{array}{l}\text { Área de captação de água, utilizada para o abastecimento } \\
\text { do município de Formosa. }\end{array}$ \\
\hline PB5 & $248426-8284776$ & 800,89 & $\begin{array}{l}\text { A jusante do núcleo urbano do município, próximos a } \\
\text { rodovia GO } 116 .\end{array}$ \\
\hline PB6 & $248773-8287121$ & 708,86 & $\begin{array}{l}\text { A jusante do núcleo urbano do município, presença de } \\
\text { atividades agropastoris. }\end{array}$ \\
\hline PB7 & $246708-8291243$ & 661,98 & $\begin{array}{l}\text { Localizado após o deságue do córrego Jenipapo, tributário } \\
\text { do Bandeirinha, margens preservadas. }\end{array}$ \\
\hline PB8 & $246891-8297253$ & 605,75 & $\begin{array}{l}\text { Localizado, próximo ao exutório da bacia do Bandeirinha } \\
\text { no Rio Paranã, margens protegidas com vegetação densa } \\
\text { e área de proteção permanente. }\end{array}$ \\
\hline \multicolumn{4}{|c|}{ Pontos Córrego Josefa Gomes } \\
\hline PJ & Coordenadas UTM & Elevação (m) & Uso e Ocupação \\
\hline PJ1 & $249564-8278950$ & 926,80 & Nascente dentro do parque municipal Mata da Bica \\
\hline $\mathrm{PJ} 2$ & $250132-8280902$ & 902,15 & $\begin{array}{l}\text { Após o trecho de } 1,5 \mathrm{~km} \text { retificado, margens apresentam } \\
\text { processo de assoreamento, resíduos sólidos, odor } \\
\text { características de efluente doméstico, além do lançamento } \\
\text { de drenagem pluvial. }\end{array}$ \\
\hline PJ3 & $251728-8281177$ & 888,10 & $\begin{array}{l}\text { Próximo ao conjunto de casa unifamiliares, recém- } \\
\text { construídas margens com a presença de resíduos sólidos. }\end{array}$ \\
\hline PJ4 & $252937-8280043$ & 879,90 & $\begin{array}{l}\text { Área com grande adensamento populacional, cerca de } 10 \\
\text { metros das residências, apresenta resíduos sólidos, } \\
\text { processo de assoreamento nas margens, odor de efluente } \\
\text { doméstico. Dista cerca de } 800 \text { metros do deságue na Lagoa } \\
\text { Feia. }\end{array}$ \\
\hline
\end{tabular}

\section{Determinações em Laboratório}

Nos 12 pontos de amostragem de sedimentos foi realizado o fracionamento granulométrico, aferição dos sólidos voláteis, determinação de elementos maiores e traços e análise por difratometria de raios- $\mathrm{x}$ da composição mineral. Todos os procedimentos foram realizados nos Laboratórios de Geoquímica e de Raios-X do Instituto de Geociências da UnB, nos Laboratórios de Saneamento e Geotecnia do Instituto Federal de Goiás, e no Laboratório da Campo Centro de Tecnologia Agrícola e Ambiental Ltda., logo após a recepção das amostras. 
A coleta e análise das amostras de sedimentos de corrente seguiram os trabalhos de (Boaventura e Moreira, 2003; Maia et al., 2005, Santos et al., 2012; Mulholland et al., 2012). Foram coletadas aproximadamente $1 \mathrm{~kg}$ manualmente com a utilização de uma pá comum. Após a coleta, as amostras foram acondicionadas em sacos plásticos de polietileno, lacradas, identificadas e mantidas em refrigeração até a chegada ao laboratório. As amostras de sedimentos foram dispostas em bandejas previamente lavadas com $\mathrm{HNO}_{3} 20 \% \mathrm{v} / \mathrm{v}$, cobertas com papel e colocadas para secar a temperatura ambiente.

Após a secagem, as amostras foram desagregadas e passaram por uma série de peneiras para o fracionamento granulométrico e a retirada de restos de folhas, plantas, pedregulhos e objetos maiores. O material passante na peneira de $0,8 \mathrm{~mm}$ foi dividido em duas subamostras: uma foi reservada para a aferição dos sólidos voláteis e determinação mineralógica e a outra, passada em peneira de nylon para separar a fração menor que $63 \mu \mathrm{m}$, a ser utilizada na determinação dos elementos maiores e traços.

Para o fracionamento granulométrico das amostras, as peneiras foram previamente limpas e encaixadas de modo a formar um conjunto com abertura de malha em ordem crescente da base para o topo e fundo fechado. Realizou-se a agitação mecânica do conjunto de peneiras por um tempo que permitisse a separação e classificação prévia dos diferentes tamanhos de grão da amostra.

A determinação dos sólidos voláteis nas amostras de sedimento foi realizada por gravimetria, seguindo as normas do Standard Methods for the Examination of Water and Wastewater (APHA, AWWA, WPCF, 1999). Porções de $2 \mathrm{~g}$ das amostras foram pesadas e colocadas para secar em estufas a $105^{\circ} \mathrm{C}$ por 24 horas para determinar seu peso seco. Em seguida, as amostras foram levadas ao forno mufla, à temperatura de $450{ }^{\circ} \mathrm{C}$, durante 24 horas. Posteriormente, foram novamente pesadas. Os resultados são apresentados em percentagem, obtidos pela diferença entre o peso inicial subtraído do peso final dado por: $\%=\left(\mathrm{P}_{\text {inicial }}-\mathrm{P}_{\text {final }}\right) * 100$.

A mineralogia das amostras de sedimentos, após fracionadas, foi identificada pela técnica da Difratometria de Raios-X (DRX), que consistiu em quatro varreduras distintas: uma da amostra total 
(t) e quatro da fração argila, orientada e seca ao ar (n), com etilenoglicol (g), com glicerol (gl) e aquecida (a). Para tanto, utilizou-se o aparelho RIGAKU D-MAXB com radiação de CuK $\alpha$, velocidade de varredura de $2^{\circ} /$ min e intervalo de medida de $0,05^{\circ}$. O intervalo de varredura foi de 2 a $65^{\circ}$ para t, de 2 a $35^{\circ}$ para n e de 2 a $35^{\circ}$ ou 2 a $25^{\circ}$ para g, gl e a, respectivamente. A preparação das amostras seguiu as técnicas e rotinas do laboratório. Para as interpretações dos difratogramas, bem como a identificação dos minerais, utilizou-se o software JADE 3.0 para Windows, XRD Pattern Procesing for the PC, 1991-1995 Materials Data, Inc.

A técnica da espectrometria de emissão com plasma indutivamente acoplado foi utilizada para a determinação dos elementos maiores e traços. Os metais presentes nas amostras precisam estar em solução; para este objetivo foi realizado o ataque com fusão de Metaborato de lítio $\left(\mathrm{LiBO}_{2}\right)$. Assim, a matriz a ser analisada passou por um processo de digestão, para que os metais sejam disponibilizados em solução (Boaventura, 1991). Esta técnica foi utilizada para determinar os elementos maiores $\mathrm{SiO}_{2}, \mathrm{Al}_{2} \mathrm{O}_{3}, \mathrm{Fe}_{2} \mathrm{O}_{3}, \mathrm{CaO}, \mathrm{MgO}, \mathrm{TiO}_{2}, \mathrm{Na}_{2} \mathrm{O}, \mathrm{K}_{2} \mathrm{O}$ com resultados ajustados para $100 \%$.

As amostras foram pesadas em cadinho de platina, aproximadamente 0,05 $\pm 0,0001 \mathrm{~g}$; logo após pesou-se 0,17 \pm 0,01 $\mathrm{g}$ de fundente $\left(\mathrm{LiBO}_{2}\right)$ no mesmo cadinho; homogeneizou-se a amostra ao fundente e conduziu-a à mufla em temperatura de $950{ }^{\circ} \mathrm{C}$ por 30 minutos. Após passar pela mufla foi dissolvida em béquer de $250 \mathrm{~mL}$ com $200 \mathrm{~mL}$ de $\mathrm{HCl}$ a $15 \%$ v/v; para finalizar o preparo da amostra, a mesma foi aquecida suavemente para ajudar na dissolução e transferiu-se a solução para o balão de 500 mL com água destilada e desmineralizada, homogeneizando-a e conduzindo-a para leitura.

Para determinação dos elementos-traço foi utilizada a digestão via ácida pelo método da água régia, pesando $1 \mathrm{~g}$ da amostra em béquer de teflon, adicionou $3 \mathrm{~mL}$ de $\mathrm{HNO}_{3} 65 \% \mathrm{v} / \mathrm{v}$ e $10 \mathrm{~mL}$ de $\mathrm{HCl} 37 \%$ v/v, a solução foi aquecida a $200{ }^{\circ} \mathrm{C}$ até perto do ponto de secura, em seguida foi adicionado $2 \mathrm{~mL} \mathrm{HNO}_{3} 65 \%$ v/v, e $5 \mathrm{~mL}$ de $\mathrm{HCl} 37 \%$ v/v, aqueceu-se novamente a $200{ }^{\circ} \mathrm{C}$ até o ponto de secura, adicionou $75 \mathrm{~mL}$ de $\mathrm{HCl} 10 \%$ v/v, aqueceu-se novamente até solubilização completa do resíduo; após 
este procedimento as amostras foram transferidas para balões volumétricos de $100 \mathrm{~mL}$, para posterior leitura dos elementos $\mathrm{Ba}, \mathrm{V}, \mathrm{Cr}, \mathrm{Mn}, \mathrm{Cu}, \mathrm{Zn}, \mathrm{P}, \mathrm{Pb}$.

As leituras foram realizadas utilizando-se um Espectrômetro de Emissão Óptica com Plasma Indutivamente Acoplado (ICP/OES), marca Spectroflame, modelo FVM03. O controle de qualidade nas análises laboratoriais foi realizado por amostra padrão de referência, amostra de controle (branco); foi usado o padrão da NIST (National Institute for Standards and Technology - USA) SEM 2709a San Joaquin Soil, e o padrão C de rocha basalto (Boaventura e Hirson, 1987). As curvas analíticas do ICP/OES foram preparadas com soluções padrões de 1000 ppm da marca Vetec. A partir delas foram feitas as diluições necessárias para cada elemento.

\section{RESULTADOS E DISCUSSÃO}

\section{Fracionamento Granulométrico}

Os resultados desta análise foram classificados de acordo com os tamanhos dos grãos, baseado na escala de Krumbein, e utilizando os métodos e procedimentos adotados pelo Laboratório de Geotecnia do Instituto Federal de Goiás - IFG. Os grãos variaram de Cascalho médio (16 - 8 mm), Cascalho fino $(8-4 \mathrm{~mm})$, Areia grossa $(1-0,50 \mathrm{~mm})$, Areia média $(0,50-0,25 \mathrm{~mm})$ e Areia fina $(0,25-0,12 \mathrm{~mm})$. A distribuição percentual dos sedimentos, conforme granulometria, está apresentado na figura 3 .

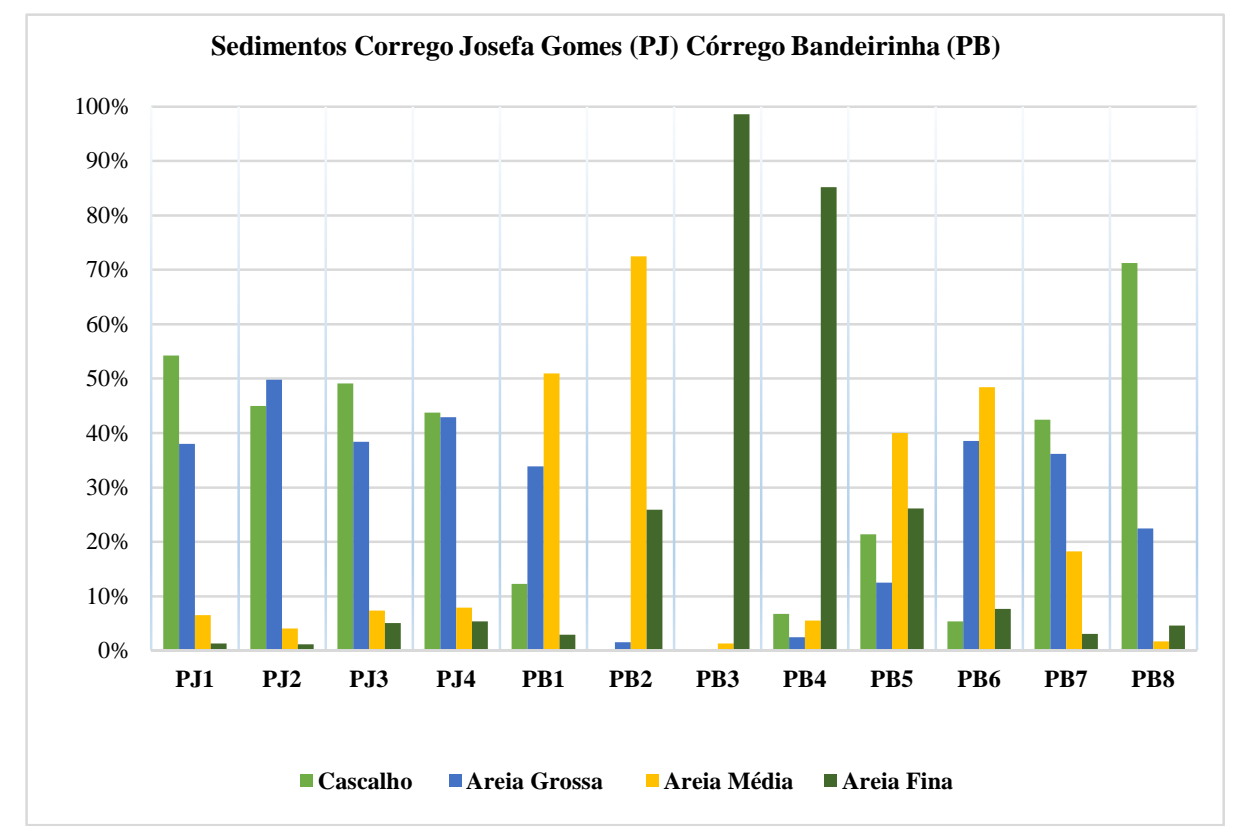

Figura 3: Caracterização granulométrica dos sedimentos nos córregos Josefa Gomes (PJ) e Bandeirinha (PB, distribuídos ao longo dos pontos de amostragem. 
Nas amostras do córrego Bandeirinha ocorreu a predominância da fração granulométrica de 0,50 a 0,12 mm, correspondendo à areia média e fina, componentes naturais presentes no leito desta drenagem. Os resultados para os sedimentos amostrados nos pontos do córrego Josefa Gomes mostram uma maior concentração de Areia grossa seguida de Cascalho fino e Cascalho médio. Essa diferença nos resultados entre as drenagens decorre que parte deste material presente no leito do Josefa Gomes provém de contribuições do sistema de águas pluviais, que carreiam estes materiais da área urbana para o curso de água.

Os resultados do fracionamento granulométrico foram condizentes com as características geológicas da região, representada pelo Grupo Paranoá e Grupo Bambuí, com coberturas DetritoLateríticas do Terciário-Quaternário e Aluviões recentes nas margens dos cursos de água, que correspondem a um depósito de sedimentos clásticos (areia, cascalho e/ou lama), formado pelo sistema fluvial no leito e nas margens dos córregos Bandeirinha e Josefa Gomes.

\section{Determinação dos Sólidos Voláteis}

No córrego Bandeirinha a média de sólidos voláteis foi de 4,5\%, tendo seu maior valor aferido $8 \%$ no ponto PB5. Este ponto é localizado à jusante do núcleo urbano do município, consequentemente recebe a influência da área urbana o que justifica o valor mais elevado. Todos os demais pontos de amostragem ficaram abaixo de $8 \%$.

O córrego Josefa Gomes apresentou valores maiores, em média de 14,5\%. O maior valor aferido foi no ponto PJ2 (18\%). Neste ponto apresentam-se as maiores intervenções antrópicas na drenagem. Ele está localizado no final do trecho retificado entre o encontro de duas vias do município e recebe o deságue do sistema de águas pluviais e lançamentos clandestinos de efluentes domésticos. Foram obtidos os seguintes resultados conforme quadro 2.

Quadro 2: Sólidos voláteis em percentagem (\%) para os córregos Bandeirinha e Josefa Gomes.

\begin{tabular}{|c|c|c|c|c|c|c|c|c|c|c|c|}
\hline \multicolumn{12}{|c|}{ Sólidos Voláteis (\%) } \\
\hline \multicolumn{8}{|c|}{ Córrego Bandeirinha } & \multicolumn{4}{|c|}{ Córrego Josefa Gomes } \\
\hline PB1 & $\overline{\text { PB2 }}$ & $\overline{\text { PB3 }}$ & PB4 & PB5 & $\overline{\text { PB6 }}$ & PB7 & PB8 & PJ1 & PJ2 & $\overline{\text { PJ3 }}$ & $\overline{\text { PJ4 }}$ \\
\hline 2 & 7 & 2 & 5 & 8 & 4 & 3 & 5 & 10 & 18 & 13 & 17 \\
\hline
\end{tabular}




\section{Mineralogia dos sedimentos}

$\mathrm{Na}$ aplicação da difratometria de raios-x, executou-se em primeiro instante a varredura em amostra total, identificando as amostras que continham argila suficiente para as demais determinações. Após essa análise os resultados foram separados em dois grupos: resultados da amostra total correspondente a todos os pontos dos córregos Bandeirinha e Josefa Gomes, e resultados das amostras com fração argila pontos do córrego Bandeirinha PB5, PB8 e todos os pontos do córrego Josefa Gomes. Os resultados são apresentados no quadro 3, e estão organizados por pontos em ordem de abundância encontrada nas amostras.

Quadro 03. Resultados da difratometria de raio-x nas amostras do Córrego Bandeirinha e Josefa Gomes

\begin{tabular}{|c|c|c|c|c|c|}
\hline \multicolumn{3}{|c|}{ Difratometria Raio-X Córrego Bandeirinha } & \multicolumn{3}{|c|}{ Difratometria Raio-X Córrego Josefa Gomes } \\
\hline Pontos & $\begin{array}{l}\text { Espécie } \\
\text { Mineral }\end{array}$ & Composição Química & Pontos & $\begin{array}{l}\text { Espécie } \\
\text { Mineral }\end{array}$ & Composição Química \\
\hline PB1 & $\begin{array}{l}\text { Quartzo } \\
\text { Gibbsita } \\
\text { Caulinita } \\
\end{array}$ & $\begin{array}{c}\mathrm{SiO}_{2} \\
\mathrm{Al}(\mathrm{OH})_{3} \\
\mathrm{Al}_{2} \mathrm{Si}_{2} \mathrm{O}_{5}(\mathrm{OH})_{4} \\
\end{array}$ & PJ1 & $\begin{array}{l}\text { Quartzo } \\
\text { Caulinita } \\
\text { Gibbsita } \\
\end{array}$ & $\begin{array}{c}\mathrm{SiO}_{2} \\
\mathrm{Al}_{2} \mathrm{Si}_{2} \mathrm{O}_{5}(\mathrm{OH})_{4} \\
\mathrm{Al}(\mathrm{OH})_{3} \\
\end{array}$ \\
\hline PB2 & $\begin{array}{l}\text { Quartzo } \\
\text { Caulinita }\end{array}$ & $\begin{array}{c}\mathrm{SiO}_{2} \\
\mathrm{Al}_{2} \mathrm{Si}_{2} \mathrm{O}_{5}(\mathrm{OH})_{4} \\
\end{array}$ & \multirow{5}{*}{ PJ2 } & $\begin{array}{l}\text { Quartzo } \\
\text { Caulinita }\end{array}$ & $\begin{array}{c}\mathrm{SiO}_{2} \\
\mathrm{Al}_{2} \mathrm{Si}_{2} \mathrm{O}_{5}(\mathrm{OH})_{4}\end{array}$ \\
\hline PB3 & Quartzo & $\mathrm{SiO}_{2}$ & & Gibbsita & $\mathrm{Al}(\mathrm{OH})_{3}$ \\
\hline PB4 & Quartzo & $\mathrm{SiO}_{2}$ & & Calcita & $\mathrm{CaCO}_{3}$ \\
\hline PB5 & $\begin{array}{l}\text { Quartzo } \\
\text { Caulinita }\end{array}$ & $\begin{array}{c}\mathrm{SiO}_{2} \\
\mathrm{Al}_{2} \mathrm{Si}_{2} \mathrm{O}_{5}(\mathrm{OH})_{4}\end{array}$ & & $\begin{array}{l}\text { Dolomita } \\
\text { Muscovita }\end{array}$ & $\begin{array}{c}\mathrm{CaMg}\left(\mathrm{CO}_{3}\right)_{2} \\
\mathrm{KAl}_{2}\left(\mathrm{Si}_{3} \mathrm{Al}\right) \mathrm{O}_{10}(\mathrm{OH}, \mathrm{F})_{2}\end{array}$ \\
\hline \multirow[b]{2}{*}{ PB6 } & Quartzo & $\mathrm{SiO}_{2}$ & & Hematita & $\mathrm{Fe}_{2} \mathrm{O}_{3}$ \\
\hline & $\begin{array}{l}\text { Caulinita } \\
\text { Microclina }\end{array}$ & $\begin{array}{c}\mathrm{Al}_{2} \mathrm{Si}_{2} \mathrm{O}_{5}(\mathrm{OH})_{4} \\
\mathrm{KAlSi}_{3} \mathrm{O}_{8}\end{array}$ & \multirow{2}{*}{ PJ3 } & $\begin{array}{l}\text { Quartzo } \\
\text { Caulinita }\end{array}$ & $\begin{array}{c}\mathrm{SiO}_{2} \\
\mathrm{Al}_{2} \mathrm{Si}_{2} \mathrm{O}_{5}(\mathrm{OH})_{4}\end{array}$ \\
\hline \multirow{2}{*}{ PB7 } & $\begin{array}{l}\text { Quartzo } \\
\text { Ortoclase }\end{array}$ & $\begin{array}{c}\mathrm{SiO}_{2} \\
(\mathrm{~K}, \mathrm{Ba}, \mathrm{Na})\left(\mathrm{Si}_{1} \mathrm{Al}\right)_{4} \mathrm{O}_{2}\end{array}$ & & $\begin{array}{l}\text { Gibbsita } \\
\text { Ilita }\end{array}$ & $\begin{array}{c}\mathrm{Al}(\mathrm{OH})_{3} \\
(\mathrm{~K}, \mathrm{H} 3 \mathrm{O}) \mathrm{Al}_{2} \mathrm{Si}_{3} \mathrm{AlO}_{10}(\mathrm{OH})_{2}\end{array}$ \\
\hline & $\begin{array}{l}\text { Caulinita } \\
\text { Ilita }\end{array}$ & $\begin{array}{c}\mathrm{Al}_{2} \mathrm{Si}_{2} \mathrm{O}_{5}(\mathrm{OH})_{4} \\
(\mathrm{~K}, \mathrm{H} 3 \mathrm{O}) \mathrm{Al}_{2} \mathrm{Si}_{3} \mathrm{AlO}_{10}(\mathrm{OH})_{2}\end{array}$ & \multirow[t]{2}{*}{ PJ4 } & $\begin{array}{l}\text { Quartzo } \\
\text { Caulinita }\end{array}$ & $\begin{array}{c}\mathrm{SiO}_{2} \\
\mathrm{Al}_{2} \mathrm{Si}_{2} \mathrm{O}_{5}(\mathrm{OH})_{4}\end{array}$ \\
\hline PB8 & $\begin{array}{l}\text { Quartzo } \\
\text { Muscovita } \\
\text { Caulinita }\end{array}$ & $\begin{array}{c}\mathrm{SiO}_{2} \\
\mathrm{KAl}_{2}\left(\mathrm{Si}_{3} \mathrm{Al}\right) \mathrm{O}_{10}(\mathrm{OH}, \mathrm{F})_{2} \\
\mathrm{Al}_{2} \mathrm{Si}_{2} \mathrm{O}_{5}(\mathrm{OH})_{4}\end{array}$ & & Gibbsita & $\mathrm{Al}(\mathrm{OH})_{3}$ \\
\hline
\end{tabular}

Os pontos amostrados no córrego Bandeirinha evidenciam a presença predominante de quartzo como maior constituinte das amostras, identificado em conjunto ou isoladamente com a caulinita, ou ainda associado com a gibbsita, ilita ou muscovita. O quartzo está presente nos sedimentos de fundo das drenagens, proveniente tanto do retrabalho do material das margens, quanto do carreamento dos sedimentos transportados pelos tributários.

Maior diversidade nos minerais é encontrada nos pontos PB6, PB7 e PB8, que estão localizados próximo ao deságue e que, recebem influências indiretas do núcleo urbano, além do carreamento natural de sedimentos que ocorre ao longo da drenagem. Foram identificados nesses 
pontos microclina, ortoclase, ilita e muscovita, espécies minerais que têm origem nos argilominerais presentes no Grupo Bambuí, onde está situada a drenagem do córrego Bandeirinha.

No córrego Josefa Gomes a determinação por difratometria de raios-x evidencia a predominância de quartzo em maior abundância, associado a caulinita e gibbsita. Existe, contudo, maior diversidade de minerais no ponto PJ2, localizado após o trecho retificado do Josefa Gomes, onde ocorre o lançamento de águas pluviais oriundas das Avenidas Ivone Sadd e Avenida Califórnia, além de processo de assoreamento em suas margens.

A maior diversidade mineral no ponto PJ2, que não é identificada nos demais pontos, está associada à aceleração do intemperismo provocado pela constante alteração geomorfológica produzida no leito da drenagem, ao carreamento de materiais, pelo uso do solo urbano, à ausência de mata ciliar, ao lançamento de águas pluviais e ao carreamento de resíduos da construção civil. O difratograma do ponto PJ2 está apresentado na figura 4.

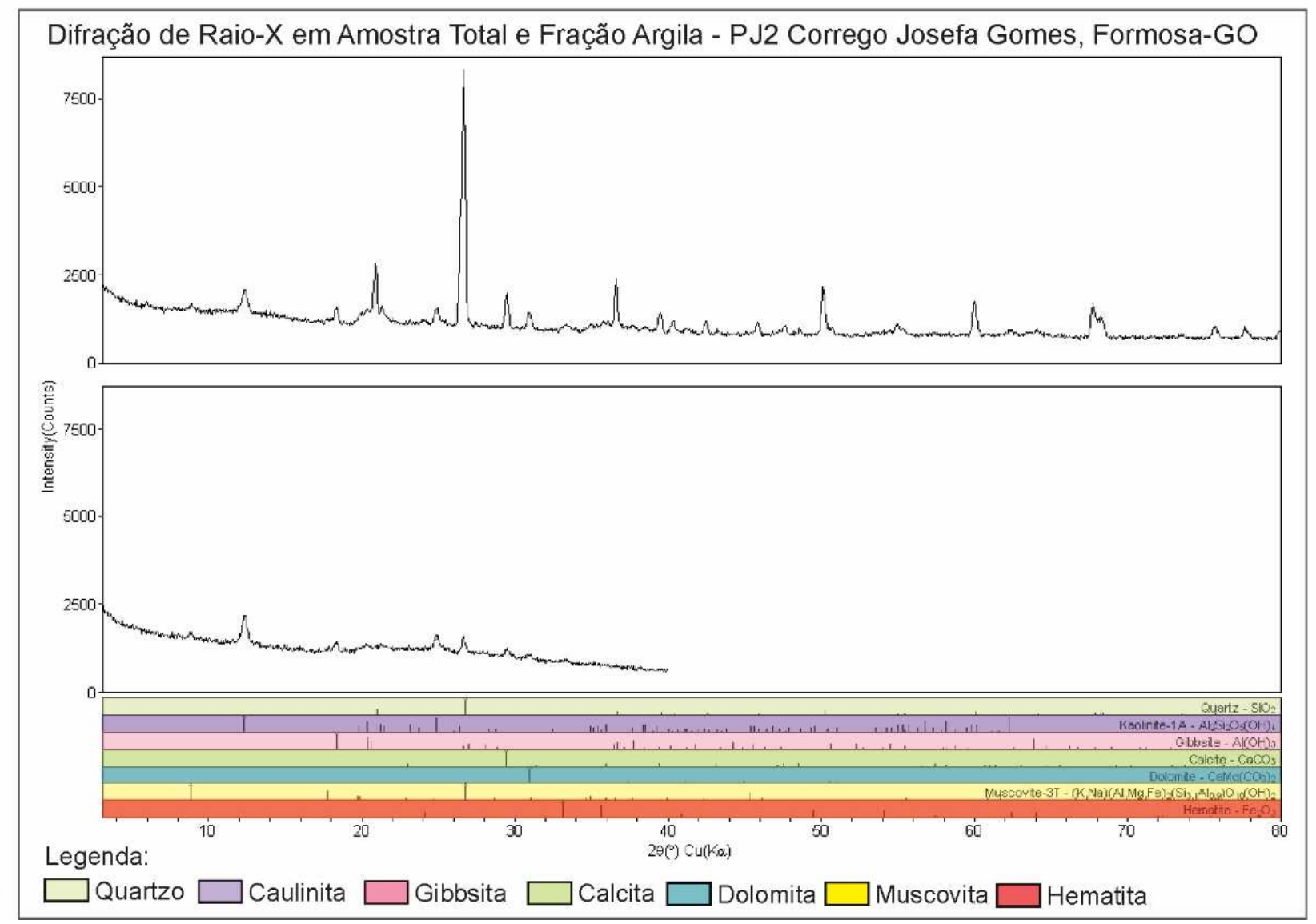

Figura 4: Difratograma ponto PJ2, córrego Josefa Gomes, Formosa-GO. 


\section{Determinação de Elementos Maiores e Traços}

Foram determinados oito elementos maiores e oito elementos-traço nos sedimentos dos córregos Josefa Gomes (PJ) e Bandeirinha (PB). Os resultados são mostrados no quadro 4.

Quadro 4. Elementos maiores e elementos-traço em amostras de sedimentos no córrego Bandeirinha e Josefa Gomes.

\begin{tabular}{|c|c|c|c|c|c|c|c|c|c|c|c|c|}
\hline \multicolumn{9}{|c|}{ Córrego Bandeirinha } & \multicolumn{4}{|c|}{ Córrego Josefa Gomes } \\
\hline $\begin{array}{c}\text { Elementos } \\
\text { Maiores } \\
(\%)\end{array}$ & PB1 & PB2 & PB3 & PB4 & PB5 & PB6 & PB7 & PB8 & PJ1 & PJ2 & PJ3 & PJ4 \\
\hline $\mathrm{SiO}_{2}$ & 87,98 & 84,17 & 78,62 & 78,53 & 68,34 & 78,47 & 76,49 & 71,24 & 49,17 & 54,9 & 65,54 & 69,15 \\
\hline $\mathrm{Al}_{2} \mathrm{O}_{3}$ & 4,71 & 0,73 & 0,96 & 1,35 & 6,52 & 5,47 & 6,29 & 6,59 & 27,83 & 6,95 & 13,4 & 11,2 \\
\hline $\mathrm{Fe}_{2} \mathrm{O}_{3}$ & 2,04 & 0,32 & 1,08 & 0,52 & 6,75 & 6,23 & 6,04 & 6,25 & 2,24 & 11,87 & 5,09 & 8,61 \\
\hline $\mathrm{CaO}$ & 0,43 & 0,32 & 0,35 & 0,37 & 0,67 & 0,65 & 0,43 & 0,52 & 0,57 & 10,48 & 0,88 & 0,6 \\
\hline MgO & 0,15 & 0,05 & 0,06 & 0,04 & 0,21 & 0,25 & 0,48 & 0,1 & 0,31 & 1,99 & 1,08 & 0,28 \\
\hline $\mathrm{TiO}_{2}$ & 0,27 & 0,04 & 0,07 & 0,09 & 0,41 & 0,3 & 0,3 & 0,1 & 2,01 & 0,41 & 0,75 & 0,61 \\
\hline $\mathrm{Na}_{2} \mathrm{O}$ & 0,63 & 0,66 & 0,74 & 1,48 & 0,62 & 0,67 & 0,66 & 0,32 & 0,66 & 0,83 & 0,7 & 0,67 \\
\hline $\mathbf{K}_{2} \mathbf{O}$ & 0,08 & 0,02 & 0,09 & 0,27 & 0,46 & 0,67 & 1,46 & 0,25 & 0,13 & 0,3 & 1,75 & 0,21 \\
\hline $\mathbf{P F}^{*}$ & 7,15 & 13,77 & 18,83 & 16,91 & 15,1 & 8,32 & 9,12 & 16,93 & 17,51 & 13,97 & 10,22 & 10,93 \\
\hline Total & 103,43 & 100,07 & 100,81 & 99,56 & 99,08 & 101,03 & 101,26 & 102,30 & 100,42 & 101,70 & 99,42 & 102,25 \\
\hline $\begin{array}{c}\text { Elementos- } \\
\text { Traço } \\
(\mathrm{mg} / \mathrm{kg})\end{array}$ & PB1 & PB2 & PB3 & PB4 & PB5 & PB6 & PB7 & PB8 & PJ1 & PJ2 & PJ3 & PJ4 \\
\hline $\mathbf{B a}$ & $<\mathrm{LD}$ & $<\mathrm{LD}$ & $<\mathrm{LD}$ & $<\mathrm{LD}$ & 4,5 & 7,7 & 3,4 & 4,4 & 3,2 & 8,4 & 0,5 & 0,1 \\
\hline V & 3,1 & $<\mathrm{LD}$ & 0,2 & 0,3 & 7,9 & 6,3 & 4,1 & 3,7 & 23,6 & 14,7 & 10,4 & 14,7 \\
\hline $\mathrm{Cr}$ & $<\mathrm{LD}$ & $<\mathrm{LD}$ & $<\mathrm{LD}$ & $<\mathrm{LD}$ & 1,5 & 2,3 & 0,9 & 1 & 4,7 & 10,2 & 7,4 & 9,7 \\
\hline Mn & $<\mathrm{LD}$ & $<\mathrm{LD}$ & $<\mathrm{LD}$ & $<\mathrm{LD}$ & 21,5 & 33,1 & 14,7 & 21,9 & 0,3 & 21,2 & $<\mathrm{LD}$ & 3,7 \\
\hline $\mathrm{Cu}$ & $<\mathrm{LD}$ & $<\mathrm{LD}$ & $<\mathrm{LD}$ & $<\mathrm{LD}$ & 0,9 & 3 & 0,5 & 0,6 & 3,3 & 2,4 & 1,1 & 0,7 \\
\hline $\mathbf{Z n}$ & 0,7 & $<\mathrm{LD}$ & 2,1 & $<\mathrm{LD}$ & 64,4 & 9,6 & 4,8 & 2,6 & 13,6 & 6,2 & 0,7 & 1,4 \\
\hline $\mathbf{P}$ & 19 & 4,8 & 8,6 & 7,8 & 34,7 & 44,2 & 42,8 & 49,5 & 93,3 & 53,2 & 23,4 & 32,9 \\
\hline $\mathbf{P b}$ & 0,7 & $<\mathrm{LD}$ & 0,1 & 0,5 & 2,8 & 3,1 & 2,2 & 2,5 & 14,6 & 7,1 & 4 & 4,2 \\
\hline
\end{tabular}

*PF - Perda ao Fogo em \% (resultados ajustados para 100\%)

$<$ LD - Menor que o Limite de Detecção

Entre os elementos maiores, $\mathrm{Si}$ e $\mathrm{Al}$ apresentaram maiores concentrações em todos os pontos analisados, consequência das características geológicas da região. Si e Al provêm do quartzo da caulinita e gibbsita, identificados pela difratometria de raios-x. Schaeffer et al. (2008), destacam que os latossolos brasileiros apresentam mineralogia da fração argila composta por caulinita, gibbsita, goethita e hematita, variando nas suas proporções, em função do grau de intemperização dos minerais primários.

No córrego Bandeirinha, destaca-se a substância $\mathrm{Na}_{2} \mathrm{O}$, que apresentou maior valor no ponto PB4 $(1,48 \%)$. Neste ponto, pela difratometria de raios-x, foi determinado apenas o quartzo. A presença de $\mathrm{Na}_{2} \mathrm{O}$ nos sedimentos, acima dos outros pontos amostrados, indica a contribuição de efluentes domésticos. À jusante do núcleo urbano do município, os pontos PB5 a PB8 apresentam maiores concentrações para as substâncias $\mathrm{Fe}, \mathrm{Ca}, \mathrm{Mg}$ e Ti, fator que decorre do intemperismo das 
rochas do Grupo Bambuí, do aumento das corredeiras na rede de drenagem do córrego Bandeirinha, que propiciam o decapeamento das áreas e desenvolvimento dos processos erosivos, e do carreamento de solo exposto, que é conduzido pela rede de águas pluviais do município. Além das contribuições antrópicas à jusante do núcleo urbano do município, o que pode ser confirmado pela maior presença de sólidos voláteis a partir do PB5.

No córrego Josefa Gomes, o ponto PJ2 teve as maiores alterações nas substâncias $\mathrm{Fe}, \mathrm{Ca}, \mathrm{Mg}$ e Na, e nos demais pontos de amostragem predominaram, na determinação de raios-x, o quartzo, a caulinita e a gibbsita, o que explica as concentrações de Si e Al. Contudo, no PJ2, foram identificados calcita, dolomita, muscovita e hematita, destacando-se também a existência de processos erosivos e solos expostos na sua margem, o que pode contribuir para esta maior diversidade dos elementos.

Pires (2012) realizou a análise dos parâmetros físico-químicos da água, com amostragens no córrego Josefa Gomes (Cabeceira do Rio Preto), e identificou concentrações de Ca e Mg nas águas superficiais, que podem ser resultado do contato da água com depósitos de calcita, dolomita e gipsita, e o magnésio do contato com minerais magnesita e dolomita. Essas espécies minerais foram determinadas pela difratometria de raios-X.

O ponto PJ2 também apresentou maior distribuição proporcional dos sedimentos no fracionamento granulométrico, indicando maior carreamento de materiais, além da maior concentração de sólidos voláteis (18\%), provenientes de contribuições de efluentes domésticos, corroborando para determinação de alterações de origem antrópica.

A concentração de Si e Al são menores quando comparadas com as do córrego Bandeirinha. As maiores diversidades na concentração dos elementos provêm do carreamento de materiais para o leito do Josefa Gomes, além dos lançamentos de águas pluviais e esgotos domésticos, consequência de sua rede de drenagem estar completamente inserida na área urbana do município de Formosa.

Para os elementos-traço, destaca-se a variação nas concentrações aferidas entre os pontos do córrego Bandeirinha. Parte dos elementos determinados apresentaram resultados abaixo do limite de 
detecção entre os pontos PB1 a PB4. Os elementos-traço são encontrados em maiores concentrações no trecho correspondente entre os pontos PB5 a PB8.

Tal fato advém das características naturais do trecho PB1 a PB4, conforme determinações granulométrica e mineralógica. Nesses pontos, o sedimento apresenta predominância de quartzo $\left(\mathrm{SiO}_{2}\right)$ e baixa quantidade de sólidos voláteis. A concentração de elementos-traço em sedimentos está associada à superfície específica do sedimento e à capacidade de troca catiônica, preferencialmente ligada a sedimentos com a presença de matéria orgânica e argilominerais.

Nos pontos PB5 a PB8 foram identificas frações argila nos sedimentos, além de maiores valores para sólidos voláteis. Esse trecho do córrego Bandeirinha está localizado à jusante do núcleo urbano do município, onde foram determinadas maiores concentrações de elementos-traço, destacando o $\mathrm{P}, \mathrm{Zn}$ e $\mathrm{Cu}$, indicativos de atividades agropastoris, tendo como principal fonte os derivados de fertilizantes e o $\mathrm{Pb}, \mathrm{V}$ e $\mathrm{Cr}$, presentes nos hidrocarbonetos e oriundos de contribuições por lançamento de águas pluviais.

As concentrações de elementos-traço foram mais evidentes nos pontos do córrego Josefa Gomes, o córrego apresentou fração argila em todos os pontos amostrados e sólidos voláteis em média de $16,25 \%$. Elementos como o $\mathrm{V}, \mathrm{Pb}, \mathrm{Cr}$ indicam a influência direta das atividades antrópicas tendo como principais fontes os hidrocarbonetos derivados dos combustíveis. O maior valor de $\mathrm{P}$, identificado no ponto PJ1, decorre dos processos de recuperação da nascente do córrego Josefa Gomes, localizada dentro do parque municipal Mata da Bica.

\section{CONCLUSÕES}

A caracterização dos sedimentos de corrente evidencia a variação dos elementos nas drenagens. Os resultados das determinações dos elementos maiores e elementos-traço e a difratometria de raios-x nos sedimentos do córrego Bandeirinha e córrego Josefa Gomes, acompanharam a geologia regional e as influências das atividades antrópicas nas drenagens. Os pontos do córrego Josefa Gomes apresentaram a maior diversidade dos elementos, destacando-se o 
ponto PJ2 com as maiores alterações nas substâncias $\mathrm{Fe}, \mathrm{Ca}, \mathrm{Mg}$ e Na, além de determinação de V, $\mathrm{Cr}, \mathrm{Cu}, \mathrm{P}$ e $\mathrm{Pb}$.

No córrego Bandeirinha, inserido em área rural do município, os sedimentos mostraram estar em conformidade com a geologia regional, apesar dos impactos gerados pelas atividades agropastoris, o que indica uma menor influência antrópica nesta drenagem. As características geológicas dos sedimentos têm influência direta na concentração de elementos-traço nesta drenagem, fato evidenciado pelos pontos PB1 a PB4 onde houve predominância de $\mathrm{SiO}_{2}$ e baixo teor de sólidos voláteis, o que desfavorece a concentração de elementos-traço nestes pontos.

Quanto ao córrego Josefa Gomes, inserido na área urbana, mesmo com uma drenagem pouco ramificada, foram registradas alterações nas características granulométricas e mineralógicas dos sedimentos, bem como maiores concentrações de elementos maiores e elementos-traço, que estão relacionadas ao deságue das águas pluviais, lançamentos de esgotos domésticos e ao uso e ocupação do solo nas margens.

Apesar de alguns valores encontrados para os elementos maiores e elementos-traço estarem relacionados às características geológicas do entorno dos córregos Bandeirinha e Josefa Gomes, as concentrações mais altas de alguns metais indicam uma influência da ação antrópica tanto em ambiente rural quanto urbano.

Os estudos dos sedimentos estão associados a preocupações com elementos-traço e maiores por seus efeitos à saúde humana. No entanto, os sedimentos têm papel importante no ecossistema aquático, por fornecerem hábitat para muitos organismos aquáticos e ser fonte e depósito de materiais orgânicos e inorgânicos.

Os resultados obtidos com este estudo podem subsidiar a interpretação de análises físicoquímica de qualidade de água e estudos com a utilização de bioindicadores nas duas drenagens, através da identificação de fatores associados com a variabilidade dos parâmetros de qualidade de água, além de auxiliar na implementação de medidas de conservação e proteção, contribuindo, assim, na geração de informações geoquímicas das águas superficiais da região. 


\section{AGRADECIMENTOS}

Os autores agradecem aos técnicos, professores e alunos do Laboratório de Geoquímica e Laboratório de Raios-X do Instituto de Geociências da UnB, ao Instituto Federal de Educação Ciência e Tecnologia de Goiás - IFG, ao CNPq e a CAPES.

\section{REFERÊNCIAS BIBLIOGRÁFICAS}

APHA, AWWA, WPCF. 1999. Standard Methods for the Examination of Water and Wastewater, 20th ed; Washington, 1496p.

BOAVENTURA, G.R.; MOREIRA, R.C.A. 2003. Referência geoquímica regional para a interpretação das concentrações de elementos químicos nos sedimentos da bacia do lago Paranoá DF, São Paulo, Brasil. Química Nova, 26(6):812-820.

BOAVENTURA, G. R. 1991. Performance do Espectrometro de Emissão Com Plasma (ICP) Spectroflame Fvm03, Para Determinação de 20 Elementos Químicos Nas Amostras de Referencia Geoquímica Dnc-1, W-2, Unb-B1 e Unb-G1. SP. In: III CONGRESSO BRASILEIRO DE GEOQUÍMICA, 1991, São Paulo. p. 423-426

BOAVENTURA, G. R; HIRSON, J. R. 1987. Amostras de Referencia Geoquímica Para Controle de Analise de Rochas. In: PRIMEIRO CONGRESSO BRASILEIRO DE GEOQUÍMICA, 1997, Anais. Porto Alegre, Brasil. p. 321-325.

CARMO M.S; BOAVENTURA G.R; ANGÉLICA R.S. 2003. Estudo Geoquímico de Sedimentos de Corrente da Bacia Hidrográfica do Rio Descoberto, Pernambuco, Brasil. Geochimica Brasiliensis, 17(2):106-120.

CARMO, M.S.; BOAVENTURA, G. R.; OLIVEIRA, E.C. 2005. Geoquímica das Águas da Bacia do Rio Descoberto, São Paulo, Brasil. Química Nova, 28(4):565-574.

CHAVES, J; GUIMARÃES E.M; SANO, E.E; 2014. Mapa Morfoestrutural da Região de BezerraCabeceiras (GO) com Base em Geoprocessamento, RJ. In: X SIMPÓSIO BRASILEIRO DE GEOGRAFIA FÍSICA APLICADA, 2014, Rio de Janeiro. p. 165-166

FARIA, A. 1995. Estratigrafia e Sistemas Deposicionais do Grupo Paranoá nas Áreas de Cristalina, Distrito Federal e São João d'Aliança - Alto Paraíso de Goiás. Dissertação (Mestrado em Geologia) - Instituto de Geociências, Universidade de Brasília, 199p.

GUIMARÃES E.M. 1997. Estudos de proveniência e diagênese, com ênfase na caracterização dos filossilicatos dos grupos Paranoá e Bambuí, na região de Bezerras-Cabeceiras, GO. Tese (Doutorado em Geologia), Universidade de Brasília, 260p.

INSTITUTO BRASILEIRO DE GEOGRAFIA E ESTATÍSTICA - IBGE, Censo 2012. Disponível em: <http://www.censo2012.ibge.gov.br/resultados_do_censo2012.php>. Acesso em: 27 Ago. 2012. 
MAIA P.D; GIMARÃES E.D; MOREIRA R.C.A; BOAVENTURA G.R. 2005. Estudo Mineralógico dos Sedimentos de Fundo do Lago Paranoá DF, São Paulo, Brasil. Brazilian Journal of Geology, 35(4):535-541.

MAURO, C.A; DANTAS, M; ROSO, F.A. 1982. Geomorfologia da Folha SD23 Brasília: Levantamento de Recursos Naturais. In: Projeto RADAMBRASIL. Rio de Janeiro: Ministério de Minas e Energia, p. 205-296.

MULHOLLAND, D.S; BOAVENTURA, G.R; ARAÚJO, D.F. 2012. Geological and anthropogenic influences on sediment metal composition in the upper Paracatu River Basin, Brazil, Berlin, Germany. Environmental Earth Sciences, 67(5):1307-1317.

PIRES, N.L. 2012. Caracterização da Qualidade da Água na Cabeceira do Rio Preto em Formosa-GO. Trabalho de Conclusão do Curso (Graduação em Química) - Universidade Estadual de Goiás, Formosa, 90p.

SANTOS, A.L.F; BORGES, L.O.S; BOAVENTURA, G.R. 2012. Indicadores de Qualidade dos Sedimentos do Ribeirão Piancó Anápolis - GO, e suas Implicações Ambientais, Sergipe, Brasil. Scientia Plena, 8(10):1-10.

SCHAEFFER, C.E.G.R.; FABRIS, J.D. \& KER, J.C. 2008. Minerals in the clay fraction of Brazilian Latosols (Oxisols): a review, Crete, Greece, Clay Miner, 43(1):137-154.

SOUZA, J.D. (Coord.). 2004. Carta Geológica do Brasil ao Milionésimo: Folha Brasília SD 23. Brasília: CPRM. 


\title{
"ESTUDO DA QUALIDADE DA ÁGUA POR MEIO DE BIOINDICADORES BENTÔNICOS EM CÓRREGOS DA ÁREA RURAL E URBANA DO MUNICÍPIO DE FORMOSA/GO".
}

Submetido ao periódico: Revista Ambiente e Água em 26/05/2015; aceito para publicação em $19 / 11 / 2015$.

\begin{tabular}{|c} 
Ambiente \& Água - An Interdisciplinary Journal of Applied Science \\
ISSN 1980-993X-doi:10.4136/1980-993X \\
www.ambi-agua.net \\
E-mail: ambi.agua@gmail.com
\end{tabular}

\section{Estudo da qualidade da água por meio de bioindicadores bentônicos em córregos da área rural e urbana}

\author{
doi:10.4136/ambi-agua.1672
}

Received: 26 May 2015; Accepted: 19 Nov. 2015

\author{
Sandro Morais Pimenta ${ }^{1 *}$; Geraldo Resende Boaventura ${ }^{2}$; \\ Alfredo Palau Peña; ${ }^{3}$ Tiago Godoi Ribeiro ${ }^{1}$ \\ IInstituto Federal de Goiás (IFG), Goiânia, GO, Brasil \\ ${ }^{2}$ Universidade de Brasflia (UnB), Brasilia, DF, Brasil \\ Departamento de Geociências \\ 'Pontifícia Universidade Católica de Goiás (PUC), Goiânia, GO, Brasil \\ Departamento de Arqueologia \\ Autor correspondente: e-mail: moraisecologia@gmail.com. \\ grbunb@unb.br, alfredo.palau@gmail.com, godoiribeiro@gmail.com
}

\section{RESUMO}

$\mathrm{Na}$ avaliação da qualidade da água, além das análises físico-químicas e geoquímicas, outros métodos podem ser utilizados para realizar estudos ou monitoramentos. $\mathrm{O}$ objetivo deste estudo foi utilizar espécies de bioindicadores bentônicos intolerantes, tolerantes e resistentes às alterações na qualidade da água de dois córregos, considerando a granulometria dos sedimentos e sólidos voláteis. Foram amostrados oito pontos no córrego Bandeirinha e quatro pontos no córrego Josefa Gomes nos meses de janeiro e setembro de 2013. Os córregos estão localizados no município de Formosa-GO. A escolha dos dois córregos deu-se por estarem inseridos em ambientes distintos. Foram utilizados os índices de diversidade Shannon $(\mathrm{H})$, Equitabilidade (E) e Similaridade de Bray-Curtis e o método de agrupamento UPGMA (Unweighted Pair Group Method with Arithmetic Mean). Foram identificadas no corrego Bandeirinha espécies bioindicadoras intolerantes às alteraçōes na qualidade da água. Os reduzidos valores aferidos de sólidos voláteis, próprios de locais com pouca alteração antrópica, e as maiores dimensōes granulométricas também corroboram uma paridade nos resultados. O córrego Josefa Gomes, completamente inserido em ambiente urbano apresentou alterações com espécies tolerantes e resistentes. Os resultados demostraram a distinção da qualidade da água em ambiente rural e urbano e a relação dos bioindicadores com os sedimentos. O estudo auxilia na interpretação das alterações na qualidade nas duas drenagens na região. A análise da qualidade da água por meio dos bioindicadores bentônicos pode ser associada às análises físico-químicas e geoquímicas da água e dos sedimentos para uma melhor interpretaçăo dos resultados.

Palavras-chave: poluição, espécies resistentes, Formosa, Goiás, sedimento. 


\title{
Estudo da qualidade da água por meio de bioindicadores bentônicos em córregos da área rural e urbana no município de Formosa/GO
}

\section{RESUMO}

$\mathrm{Na}$ avaliação da qualidade da água, além das análises físico-químicas e geoquímicas, outros métodos podem ser utilizados para realizar estudos ou monitoramentos. O objetivo deste estudo foi utilizar espécies de bioindicadores bentônicos intolerantes, tolerantes e resistentes às alterações na qualidade da água, durante os períodos chuvoso e seco, e relacionar estes à granulometria dos sedimentos e sólidos voláteis. Foram amostrados 8 pontos no córrego Bandeirinha e 4 pontos no córrego Josefa Gomes nos meses de janeiro e setembro de 2013. Os córregos estão localizados no município de Formosa-GO. A escolha dos dois córregos deu-se por estarem inseridos em ambientes distintos, proporcionando respostas características. Nos resultados do bioindicadores foram utilizados os índices ecológicos de diversidade Shannon (H), Equitabilidade (E) e Similaridade de Bray-Curtis com o agrupamento UPGMA (Unweighted Pair Group Method with Arithmetic Mean). Os reduzidos valores aferidos de sólidos voláteis e as maiores dimensões granulométricas, identificadas no córrego Bandeirinha, localizado em área rural, condizem com a distribuição das espécies bioindicadoras intolerantes às alterações na qualidade da água. O córrego Josefa Gomes, completamente inserido em ambiente urbano apresentou alterações, sendo identificadas espécies tolerantes e resistentes. Os resultados demostraram a distinção da qualidade da água em ambiente rural e urbano e a relação dos bioindicadores com os sedimentos de corrente. O estudo auxilia na interpretação das alterações na qualidade da água além de contribuir com a geração de dados sobre as duas drenagens na região. A análise por meio dos bioindicadores bentônicos pode ser associada às análises físico-químicas e geoquímicas da água e dos sedimentos, proporcionando uma melhor interpretação dos resultados. Palavras-chave: poluição, espécies resistentes, Formosa, sedimento.

\section{Study of water quality using biological indicators for benthic inserted streams in rural and urban areas of the municipality of Formosa/GO.}

\begin{abstract}
In the assessment of water quality in surface drainage, despite the physical-chemical and geochemical analyses, other methods can be used to study or monitoring. The objective of this study was to use bioindicators benthic species intolerant, tolerant and resistant to changes in water quality in the rainy and dry seasons, is to relate these to the particle size of the current volatile solids and sediments. We sampled 8 points in the stream Bandeirinha and 4 points in the stream Josefa Gomes in January and September 2013 in the municipality of Formosa-GO. The choice of the two streams was given for being inserted into different environments, providing features answers. The results of bioindicators ecological diversity indexes Shannon were used (H), Equitability (E) and Bray-Curtis similarity with the UPGMA (Unweighted Pair Group Method with Arithmetic Mean) grouping. Reduced volatile solids measured values and larger granulometry dimensions, identified in Bandeirinha, stream located in rural areas, consistent with the distribution of intolerant bioindicators to changes in water quality. The stream Josefa Gomes, completely inserted in an urban environment presented alteration identified tolerant and resistant species. The results demonstrate the water quality of the distinction in rural and urban environment and the relationship of the bioindicators with the stream sediments. The study helps in the interpretation of changes in water quality and contribute to the generation of data on the two drainages in the area. The analysis by means of benthic bioindicators can be associated with physicochemical and geochemical analyses of water and sediments, providing a better interpretation of the results, to determine the quality in surface drainage. Keywords: pollution, resistant species, Formosa, sediment.
\end{abstract}




\section{INTRODUÇÃO}

A avaliação da qualidade da água, nas drenagens superficiais, pelos parâmetros físicoquímicos e geoquímicos pode ser associada à utilização de bioindicadores, que é a observação e acompanhamento da espécie ou grupo indicador durante um intervalo de tempo, visando obter informações sobre a condição do ambiente e mudanças nas comunidades biológicas (Mugnai et al., 2010).

A bioindicação usa alguns organismos que compõem um determinado ambiente para caracterizá-lo, a partir do conhecimento do comportamento das comunidades ecológicas quando submetidas a fatores estressantes, como a supressão da vegetação, perda de habitats, mudança da paisagem, poluição e outras. As comunidades biológicas com a presença de poluentes na água sofrem alterações em densidade e riqueza, com isso são capazes de indicar o efeito das ações antrópicas ou naturais no ambiente, o que permite uma avaliação biológica eficiente na identificação dos fatores atuantes (Chalar, 1994).

Para Callisto e Moreno (2006), espécie indicadora é aquela que possui pequena tolerância a variações ambientais e, quando presentes em determinada área, revela um conjunto de condições particulares daquele ambiente. A essência da bioindicação são as relações entre os seres vivos e os fatores ambientais. Assim, rápidas mudanças do ambiente provocadas pelo homem causam flutuações populacionais nos organismos. Cada espécie possui um padrão de variação característico: algumas são mais tolerantes, outras menos.

De acordo com Ribeiro e Uieda, (2005), ainda que as análises físico-químicas demonstrem o estado da água, o ideal é a associação desses métodos com métodos biológicos, permitindo uma caracterização mais completa, abrangendo os aspectos biológicos e a interação entre o meio físico, muitas vezes necessária para o manejo adequado dos recursos hídricos. Os indicadores biológicos têm sido considerados eficientes para medir a qualidade da água com baixos custos.

É recomendado pela Agência de Proteção Ambiental dos Estados Unidos (U.S Environmental Protection Agency - EPA) a utilização de bioindicadores para avaliar a integridade ecológica de uma área impactada, pouco impactada, ou áreas de referência, e complementar as informações sobre qualidade de água, baseadas em parâmetros físicoquímicos. (USEPA, 2013).

Callisto et al. (2004) apontam que a capacidade de sensibilidade às alterações do meio ambiente é o que determina a escolha dos bioindicadores, sendo os mais utilizados aqueles capazes de diferenciar entre oscilações naturais e alterações antrópicas, podendo indicar a presença e a dimensão de um determinado impacto ou anomalia no ambiente.

Milesi et al. (2008), afirmam que os macroinvertebrados bentônicos constituem um dos melhores bioindicadores de qualidade das águas nos ambientes lóticos, pois possuem características sésseis, ciclo de vida relativamente longo e são de fácil visualização.

Os macroinvertebrados referem-se à fauna de invertebrados que fica retida em uma malha de $0,2 \mathrm{~mm}$, sendo ela constituída por diversos táxons, tais como Arthropoda, Mollusca, Annelida e Platyhelminthes, dentre outros. A maioria dessas espécies estão associadas aos habitats de fundo das drenagens superficiais e lagos, fixos ou não a um substrato, sendo denominada de comunidade bentônica. (Maenpaa et al., 2003).

Callisto et al. (2004) destacam que as amostragens de bentos são relativamente fáceis e baratas. Os bentos são variavelmente sensíveis às condições ambientais, são sedentários, podem integrar e acumular condições em um ambiente, oferecendo um adequado nível de diagnóstico, considerando a natureza dos efeitos observados.

A utilização de bioindicadores para o monitoramento ambiental, com ênfase em insetos aquáticos é empregada em outros países, com métodos bem definidos e comunidades bioindicadoras conhecidas. Os macroinvertebrados bentônicos têm sido amplamente utilizados 
como bioindicadores de qualidade de água, por apresentarem as seguintes características: Ciclos de vida longo, podem viver entre semanas, meses e mesmo mais de 1 ano; Em geral são organismos grandes (maiores que 125 ou $250 \mu \mathrm{m}$ ), sésseis ou de pouca mobilidade, portando mais fáceis de serem amostrados, com custos relativamente baixos; grande diversidade taxonômica e de identificação relativamente fácil (ao nível de família e alguns gêneros); e são organismos sensíveis a diferentes concentrações de poluentes no meio. (Callisto e Moreno, 2006).

A utilização dos bioindicadores pode também ser mais direcionada a um tipo de poluição. Belmejo e Martos (2008) utilizaram bioindicadores sensíveis à poluição hídrica de derivados de petróleo em condições tropicais, impacto diretamente relacionado a drenagens localizadas em ambientes urbanos.

Neste entendimento Milesi et al. (2008), realizaram o estudo dos efeitos dos metais Cobre e Zinco em comunidades de macroinvertebrados bentônicos, por estes íons metálicos estarem presente em fertilizantes e pesticidas além de resíduos orgânicos provenientes de áreas urbanas; portanto, sua correlação com os bioindicadores, pode ser utilizada na identificação de impactos e análise da qualidade da água em drenagens urbanas ou rurais.

Colpo et al. (2009) utilizando os macroinvertebrados bentônicos como indicadores do impacto ambiental promovido pelos efluentes de áreas orizícolas e os de origem urbana/industrial, concluíram que os efluentes produzidos pelas cidades e indústrias, são mais agressivos aos ambientes aquáticos que os efluentes drenados de uma lavoura manejada de acordo com as recomendações técnicas para a cultura.

Estudos mais recentes, como os de Yokoyama (2012), destacam a importância dos bioindicadores na avaliação da qualidade da água e seu comportamento, com a flutuação da riqueza de táxons em resposta à variação da precipitação entre os períodos seco e chuvoso. Este efeito deve ser considerado ao realizar os estudos e monitoramento da qualidade da água em uma drenagem superficial.

O objetivo deste trabalho foi realizar o estudo da qualidade da água por meio de bioindicadores da comunidade bentônica, análise granulométrica dos sedimentos de corrente e sólidos voláteis, comparando os resultados do córrego Bandeirinha situado em ambiente predominantemente rural e o córrego Josefa Gomes, inserido no núcleo urbano do município de Formosa-GO. A aplicação da avaliação da qualidade da água por bioindicadores, nas duas drenagens auxilia na determinação das possíveis contaminações provenientes das atividades antrópicas no ambiente rural e urbano do município de Formosa, bem como as consequências a médio e longo prazo, além de contribuir com a geração de dados e caracterização regional.

\section{MATERIAL E MÉTODOS}

\section{1. Área de Estudo}

Como área representativa para o desenvolvimento da pesquisa, optou-se pelos córregos Bandeirinha e Josefa Gomes localizados no município de Formosa-GO, e estes situam-se na microrregião do entorno de Brasília. O córrego Bandeirinha, está inserido em ambiente rural e o córrego Josefa Gomes em ambiente urbano. A escolha das duas drenagens para o desenvolvimento do estudo, deu-se por possuírem características distintas; porém, localizadas na mesma região, o que permite a comparação da aplicação dos métodos de análise em ambos ambientes e a avaliação do comportamento destes, sujeitos a impactos ambientais diversos, do meio rural e do meio urbano. O município de Formosa-GO, situa-se a $280 \mathrm{~km}$ da capital do estado, Goiânia e a $70 \mathrm{~km}$ de Brasília, possui uma população total de 100.085 habitantes, sendo distribuída em 92.023 habitantes em zona urbana e 8.062 em zona rural (IBGE, 2012). A agropecuária é atividade estruturante na economia de Formosa, principalmente a pecuária de corte e leite. 
A região onde está inserido o município de Formosa possui clima Aw, segundo a classificação de Köppen. A distribuição pluviométrica é padrão típico do domínio morfoclimático dos cerrados, com precipitação média anual na ordem de $1.485 \mathrm{~mm}$, concentrando-se principalmente nos meses de outubro a abril. Nos meses de junho e julho as precipitações são praticamente ausentes. A temperatura média anual é em torno de $21,5^{\circ} \mathrm{C}$.

O córrego Bandeirinha tem suas nascentes localizadas na Fazenda Bandeirinha, dentro do município de Formosa, sob as coordenadas UTM (WGS SAE 69) $0235931.00 \mathrm{~m}$ E; $8285262.00 \mathrm{~m} \mathrm{~S}$, em altitudes médias de 1.130 metros, com um percurso de 41,96 km direção Norte, desaguando no Rio Paranã, em altitude aproximada de 600 metros, próximo a Serra Laranjeira. A drenagem principal da bacia dista do seu meandro mais próximo cerca de $2 \mathrm{~km}$ do núcleo urbano de Formosa, porém recebe contribuições antrópicas por alguns dos seus tributários, localizados na área urbana. Atualmente o córrego Bandeirinha é o principal manancial aproveitado pelo sistema de abastecimento de água no município.

A bacia hidrográfica que forma a cabeceira do Rio Preto está inserida dentro da área urbana de Formosa. Na área urbana este córrego tem o nome de Josefa Gomes, e tem percurso de 7,5 km direção sudoeste. Sua nascente localiza-se no parque municipal Mata da Bica sob as coordenadas UTM (WGS SAE 69) 0249481.00 m E; 8278785.00 m S, com elevação de 945 metros desaguando na Lagoa Feia em elevação de 873 metros. A área da nascente no Parque Municipal Ecológico Mata da Bica possui várias surgências de água, que se unem ao longo da área do parque formando a Lagoa da Mata da Bica e está por consequência, alimenta a vazão do Córrego Josefa Gomes. Parte do percurso do córrego Josefa Gomes é retificado, principiando na lagoa da Mata da Bica, e se estendendo aproximadamente 1,5 km de percurso, e possuindo 2,5 metros de largura. Após a retificação o córrego Josefa Gomes percorre aproximadamente 6 km e deságua na Lagoa Feia. Em seguida a Lagoa Feia o córrego é denominado Rio Preto e possui uma área de drenagem de aproximadamente $10.500 \mathrm{~km}^{2}$ abrangendo os Estados de Goiás, Distrito Federal e Minas Gerais. O Rio Preto é um dos principais tributários do rio Paracatu, no Estado de Minas Gerais, e este é afluente do Rio São Francisco.

Conforme a carta geológica do Serviço Geológico Nacional a região do córrego Bandeirinha no alto da bacia está situado em rochas do grupo Paranoá, e nas regiões média e baixa da bacia predomina as rochas do grupo Bambuí. O córrego Josefa Gomes está completamente inserido em rochas do grupo Paranoá da sua nascente ao seu deságue (Souza et al., 2004).

Faria (1995) descreveu que as aluviões da região são caracterizadas por sedimentos inconsolidados, dominantemente arenosos, representados por areias, com níveis de cascalhos, e lentes de material silto-argiloso.

\subsection{Amostragem e Análises}

Para a realização do estudo foram determinados 8 pontos espacializados no córrego Bandeirinha, e 4 pontos no córrego Josefa Gomes, figura 1. A seleção dos pontos de amostragem deu-se considerando as atividades antrópicas ao longo da drenagem e a incidência de tributários. As coletas ocorreram nos meses de janeiro e setembro de 2013, de acordo com os períodos chuvoso e seco da região. Os 8 pontos de amostragem no córrego Bandeirinha, e os 4 pontos de amostragem no córrego Josefa Gomes, seguem da nascente até o deságue das drenagens. 


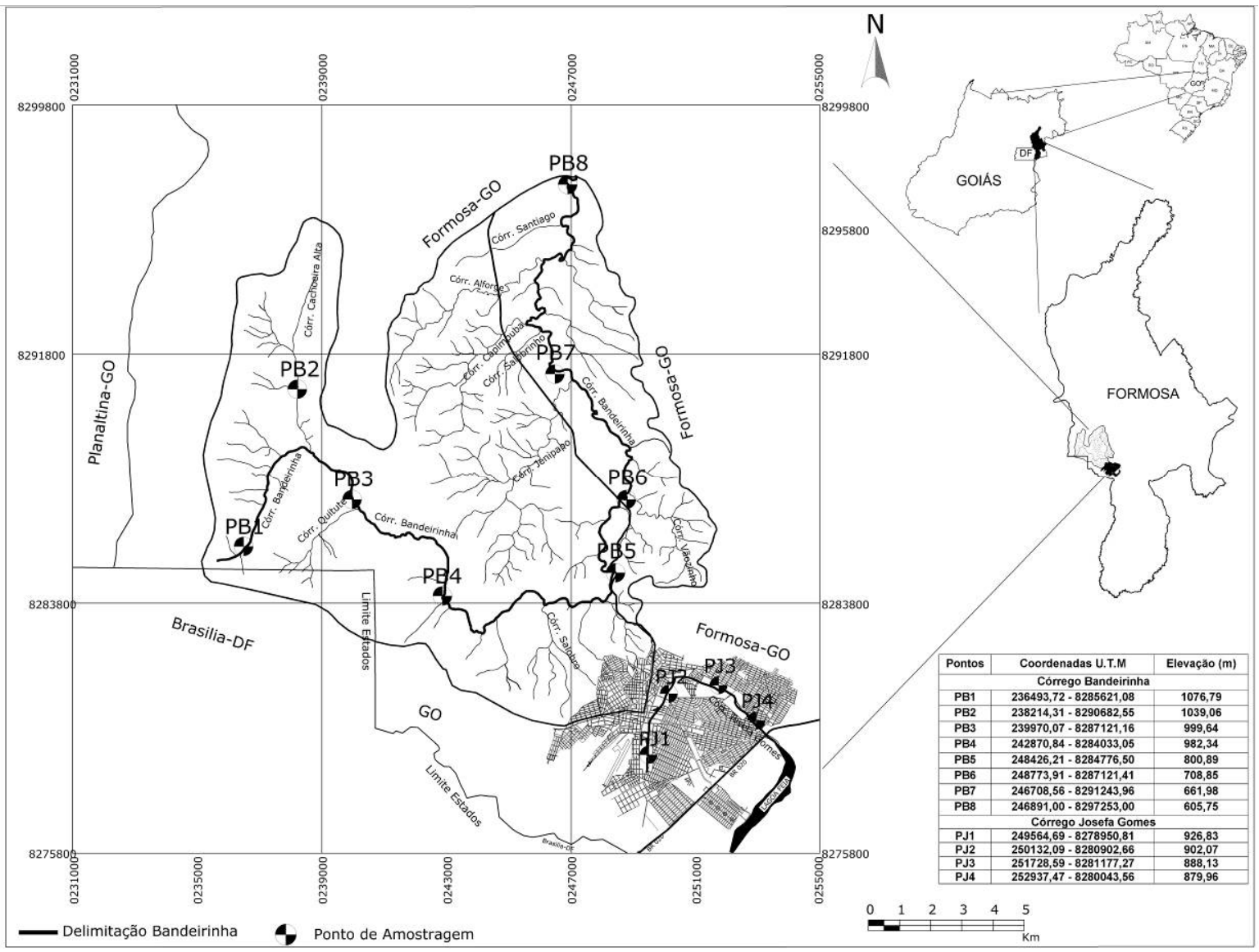

Figura 1. Localização da área, pontos de amostragem nos córregos Bandeirinha e Josefa Gomes, Formosa-GO. Fonte: IBGE 2012.

As análises foram realizadas no Laboratório de Geoquímica da Universidade de Brasília - LabGeq, e nos Laboratórios do Instituto Federal de Goiás, logo após a recepção das amostras. Nos pontos de amostragem foram coletadas amostras de sedimentos de corrente, uma vez que as dimensões das partículas que compõe as amostras de sedimentos são importantes para a caracterização dos habitats dos macroinvertebrados bentônicos. As amostras de sedimentos foram dispostas em bandejas previamente lavadas com $\mathrm{HNO}_{3} 20 \% \mathrm{v} / \mathrm{v}$, cobertas com papel e colocadas para secar à temperatura ambiente. Após secagem, as amostras foram desagregadas e passaram por uma série de peneiras, a fim de identificar sua granulometria, retirando-se restos de folhas, plantas, pedregulhos e objetos maiores. Parte do material passante foi reservado para ser utilizado na determinação dos sólidos voláteis.

O procedimento para a avaliação da composição granulométrica seguiu a metodologia do laboratório de geotecnia do Instituto Federal de Goiás. Para a caracterização da granulometria das amostras, utilizou-se o jogo de peneiras com malhas nas seguintes ordens: $10 \mathrm{~mm}-5 \mathrm{~mm}-2,5 \mathrm{~mm}-0,8 \mathrm{~mm}-0,5 \mathrm{~mm}-0,125 \mathrm{~mm}-0,1 \mathrm{~mm}$. As peneiras foram previamente limpas e encaixadas de modo a formar um único conjunto com abertura de malha em ordem crescente da base para o topo, e fundo fechado. Após este procedimento promoveuse a agitação mecânica do conjunto, para permitir a separação e classificação prévia dos diferentes tamanhos de grão da amostra. No material retido é calculado a composição granulométrica em função do peso da amostra e apresentado em percentagem sobre o total da amostra.

A determinação dos sólidos voláteis nos sedimentos, seguiu os procedimentos estabelecidos pela Standard Methods for the Examination of Water and Wastewater (APHA, 1999). Esta determinação foi realizada por gravimetria no laboratório de Geoquímica da UnB. 
Massas de $2 \mathrm{~g}$ das amostras foram pesadas em balança METLER modelo AG. 240 com variação de $\pm 0,00001 \mathrm{~g}$ e colocadas para secar em estufas a $105^{\circ} \mathrm{C}$ por 24 horas para determinar seu peso seco. Em seguida, as amostras foram levadas ao forno mufla, a temperatura de $450^{\circ} \mathrm{C}$, durante 24 horas, para que toda matéria orgânica e parte dos ânions volatilizassem. Posteriormente, foram novamente pesadas. O resultado é dado pela diferença entre o peso inicial subtraído do peso final.

Para análise dos bioindicadores foram utilizados os invertebrados bentônicos, coletados nos pontos onde se realizaram as amostragens de sedimentos de corrente. Os bentos foram, coletados com um amostrador tipo Surber com armação dobrável em aço, tela de nylon $250 \mu$ de abertura na malha, dimensões de abertura de 30 x $30 \mathrm{~cm}$ e comprimento de $60 \mathrm{~cm}$. Foram realizadas 5 réplicas de coleta por ponto em período sazonal. Após coletadas as amostras de bentos foram acondicionados individualmente em frascos plásticos e fixados com álcool $80 \%$ v/v, para identificação e contagem dos táxons encontrados, seguindo os trabalhos de Callisto et al. (2004), Borisko et al. (2007), Pimenta et al. (2009) e Mugnai et al. (2010).

A identificação dos táxons foi realizada por meio de Lupa binocular estereoscópica e os indivíduos foram identificados em ordem, família e gênero. Os bioindicadores foram divididos segundo Callisto et al. (2004) e Pimenta et al. (2009) em três grupos quanto a sua tolerância: organismos sensíveis ou intolerantes (representantes de Trichoptera, Plecoptera, Ephemeroptera), organismos tolerantes (representantes de Coleóptera, Heteroptera, Odonata) e organismos resistentes (Díptera, Oligochaeta).

Para o tratamento dos dados obtidos pelos bioindicadores, realizam-se cálculos dos índices ecológicos da diversidade Shannon (H), Equitabilidade (E) conforme Magurran, (1988) e Similaridade de Bray-Curtis com o agrupamento UPGMA (Unweighted Pair Group Method with Arithmetic Mean), nestes cálculos foi utilizado o programa BioDiversity Professional Version 2.

\section{RESULTADOS E DISCUSSÃO}

Os resultados da composição granulométrica foram classificados de acordo com os tamanhos dos grãos, utilizando a escala de Wentworth, conforme os procedimentos adotados pelo Laboratório de Geotecnia do Instituto Federal de Goiás, assim classificados: Cascalho (8 a $2 \mathrm{~mm})$; Areia grossa (1 a $0,5 \mathrm{~mm})$; Areia média $(0,5$ a $0,25 \mathrm{~mm})$; Areia fina $(0,25 \mathrm{~mm}$ a 0,125 $\mathrm{mm})$. Estão apresentados conforme Figura 2.

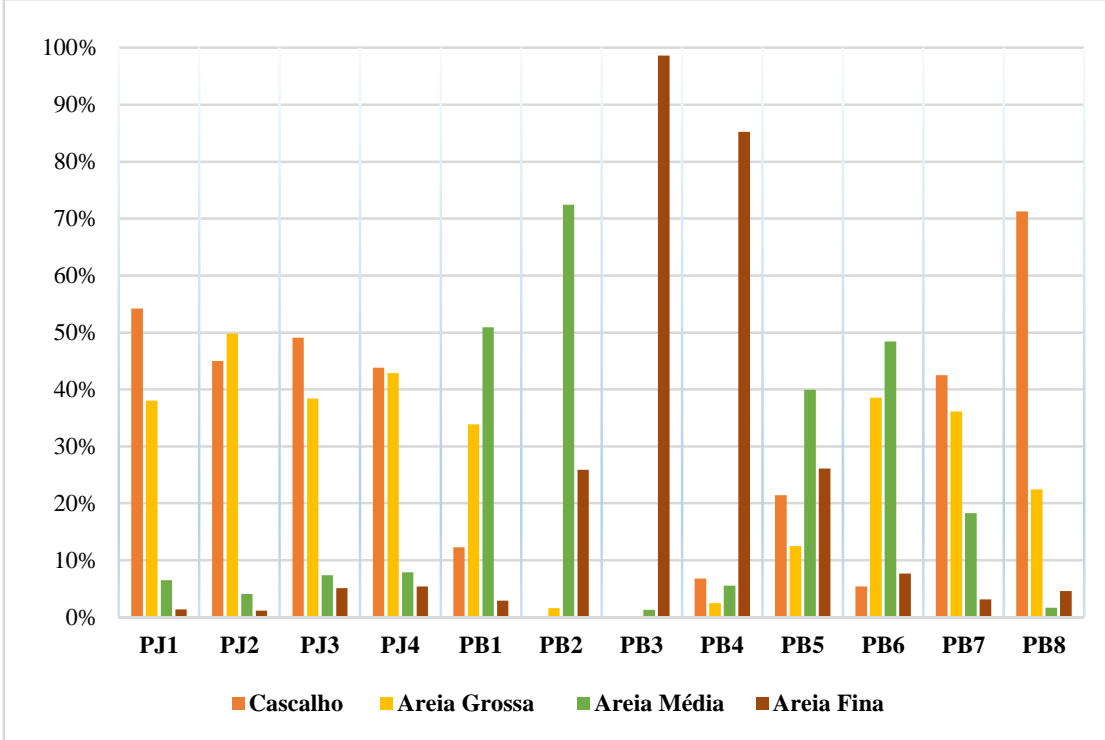

Figura 2. Percentagem de ocorrência das classes granulométricas dos sedimentos nos córregos Josefa Gomes e Bandeirinha, pontos de amostragem. 
Nos sedimentos amostrados, no córrego Bandeirinha destaca-se o ponto PB3, com o maior percentual composto por areia fina. A maioria dos pontos amostrados apresentou sedimento com distribuição entre Areia Fina - Areia Média - Areia Grossa, componentes naturais presentes no leito desta drenagem. Os sedimentos amostrados nos pontos do córrego Josefa Gomes demonstraram uma maior concentração de Areia Grossa a Cascalho. Partes deste material presente no leito desta drenagem provêm de contribuições antrópicas de construções, próximas ao córrego, lançadas pelas ligações do sistema de drenagem pluvial. A granulometria está em conformidade com as características geológicas da região, representadas pelo Grupo Paranoá e Grupo Bambuí, com aluviões recentes nas margens dos cursos de água, correspondendo a um depósito de sedimentos clásticos (areia e ou cascalho) formado pelo sistema fluvial no leito e nas margens dos córregos Bandeirinha e Josefa Gomes.

Os resultados da análise de sólidos voláteis representam parte da matéria orgânica e argilo minerais presentes nas amostras que se volatilizaram, pelo procedimento. Estes resultados são apresentados em percentagem pela diferença entre o peso inicial subtraído do peso final dado por: $\%=\left(\mathrm{P}_{\text {inicial }}-\mathrm{P}_{\text {final }}\right)^{*} 100$. As análises de sólidos voláteis nos pontos do córrego Bandeirinha indicam tendência nos valores percentuais mantendo-se abaixo dos $10 \%$ com média de 4,5\%, tendo seus maiores valores no PB2 (7\%), ponto localizado a cerca de 700 $\mathrm{m}$ de uma produção de hortaliça em área rural, e ponto PB5 (8\%), localizado a jusante do núcleo urbano do município, próximos a rodovia GO 116.

Para o córrego Josefa Gomes os percentuais encontrados são maiores que no córrego Bandeirinha. Da nascente no Parque Mata da Bica até próximo ao deságue na Lagoa Feia apresentou média de $14,5 \%$, tendo a maior aferição no PJ2 (18\%). Os maiores percentuais encontrados no córrego Josefa Gomes podem ser justificados por estar inserido em ambiente urbano e com diversas alterações antrópicas no seu canal e em suas margens.

$\mathrm{Na}$ amostragem dos bioindicadores realizada em ambas as drenagens, foram identificados 64 táxons com um total de 1.236 indivíduos, sendo 816 e 420 indivíduos respectivamente para o córrego Bandeirinha e córrego Josefa Gomes. Na estação seca foram amostrados 58 táxons e três vezes mais indivíduos $(\mathrm{N}=966)$ que a estação chuvosa $(\mathrm{N}=270)$ com 50 táxons.

Na Tabela 1, estão representados os índices de diversidade $(\mathrm{H})$ que variaram entre 1,372 (PJ2) a 3,15 (PB3) e equitabilidade (E) entre 0,5723 (PJ2) a 0,909 (PB3), com a evidência de maiores índices para os pontos mais a montante do córrego Bandeirinha, e mais a jusante no córrego Josefa Gomes.

Tabela 1. Índices de diversidade para os 12 pontos amostrados entre as drenagens dos córregos Bandeirinha (PB) e Josefa Gomes (PJ), Formosa-GO.

\begin{tabular}{ccccc}
\hline Pontos & Espécies & Espécimes & Shannon $(\mathbf{H})$ & Equitabilidade $(\mathbf{E})$ \\
\hline PJ1 & 15 & 125 & 1,904 & 0,7031 \\
PJ2 & 11 & 165 & 1,372 & 0,5723 \\
PJ3 & 17 & 90 & 2,202 & 0,7773 \\
PJ4 & 16 & 40 & 2,484 & 0,8958 \\
\hline PB1 & 29 & 122 & 2,769 & 0,8223 \\
PB2 & 39 & 113 & 3,121 & 0,852 \\
PB3 & 32 & 96 & 3,15 & 0,909 \\
PB4 & 23 & 124 & 2,679 & 0,8545 \\
PB5 & 18 & 52 & 2,541 & 0,8792 \\
PB6 & 23 & 85 & 2,699 & 0,8608 \\
PB7 & 20 & 83 & 2,429 & 0,811 \\
PB8 & 21 & 141 & 2,387 & 0,7841 \\
\hline
\end{tabular}

$\mathrm{Na}$ análise da similaridade entre os pontos amostrados no córrego Bandeirinha variou entre $24,32 \%$ a $50,19 \%$, já para os pontos do córrego Josefa Gomes a variação foi maior entre 
$18,53 \%$ a $65,51 \%$ da amostragem, figura 3 , e apresenta uma dissimilaridade entre as duas drenagens.

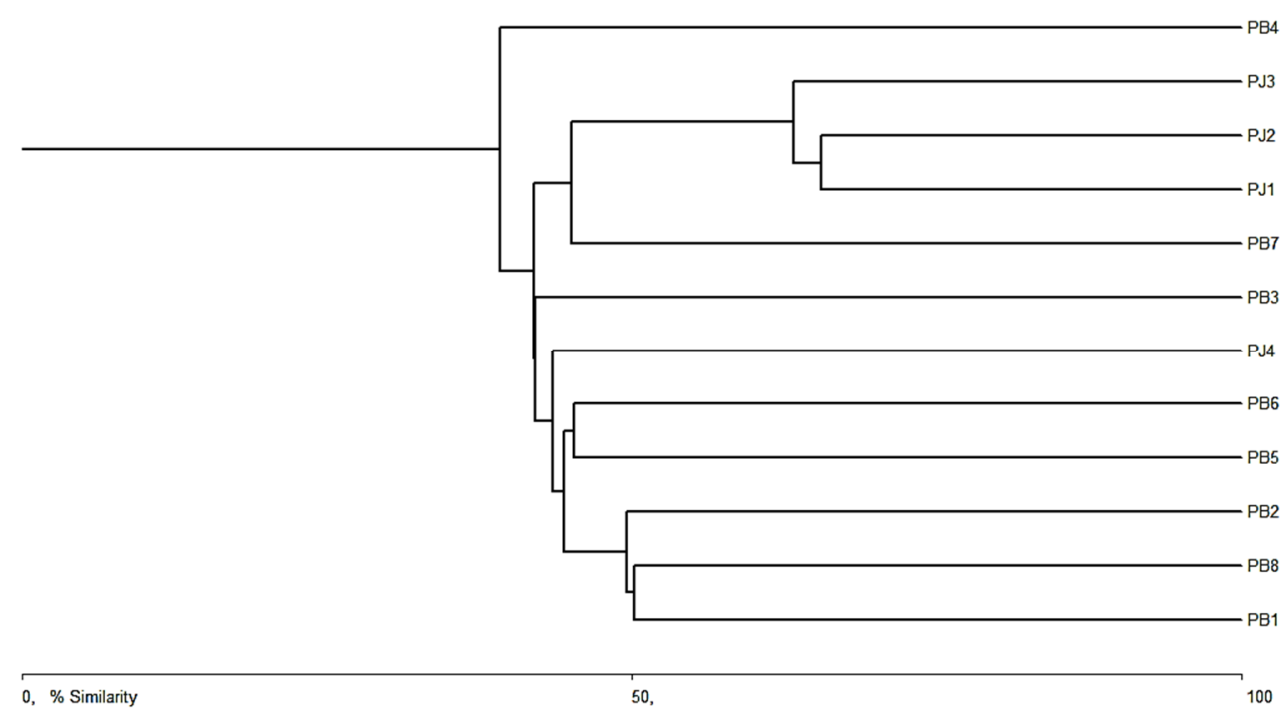

Figura 3. Análise de agrupamento (UPGMA) realizada a partir da matriz dos coeficientes de similaridade de Bray-Curtis, para os 12 pontos amostrados. Pontos córrego Bandeirinha (PB); Pontos córrego Josefa Gomes (PJ).

O efeito sazonal marcado pelas amostragens dos períodos seco e chuvoso evidenciou um padrão espaço-temporal. Hauer e Resh (1996) afirmam que períodos secos e chuvosos também influenciam na distribuição desses organismos em seu habitat, pois alteram as características do substrato, disponibilidade de alimento e refúgio. O padrão espacial encontrado provavelmente pode estar relacionado ao tipo de substrato, que é fundamental para ocupação desses microhabitas tanto na fixação como na obtenção de alimento e refúgio pelos organismos (Hauer e Resh, 1996; Carvalho e Uieda, 2004).

Os macroinvertebrados bentônicos depois de identificados foram classificados, quanto a sua função de bioindicadores, sensíveis às mudanças que se sucedem na estrutura das comunidades bentônicas que variam de organismos próprios de águas limpas, intolerantes à poluição, a simples e de baixa diversidade, com organismos capazes de viver em águas poluídas. Os bioindicadores foram divididos em três grupos principais, existindo exceções dentro de cada grupo: organismos sensíveis ou intolerantes, organismos tolerantes e organismos resistentes, conforme apresentados na Tabela 2. 
Tabela 2. Densidades dos táxons amostrados nos córregos Bandeirinha (PB) e Josefa Gomes (PJ), classificados por seu grau de tolerância, segundo Callisto et al (2004). $\mathrm{C}=$ período chuvoso; $\mathrm{S}=$ período seco.

\begin{tabular}{|c|c|c|c|c|c|c|c|c|c|c|c|c|c|c|c|c|c|c|c|c|c|c|c|c|c|}
\hline \multirow{2}{*}{\multicolumn{2}{|c|}{ Bioindicadores }} & \multicolumn{16}{|c|}{ Córrego Bandeirinha } & \multicolumn{8}{|c|}{ Córrego Josefa Gomes } \\
\hline & & \multicolumn{2}{|c|}{ PB1 } & \multicolumn{2}{|c|}{ PB2 } & \multicolumn{2}{|c|}{ PB3 } & \multicolumn{2}{|c|}{ PB4 } & \multicolumn{2}{|c|}{ PB5 } & \multicolumn{2}{|c|}{ PB6 } & \multicolumn{2}{|c|}{ PB7 } & \multicolumn{2}{|c|}{ PB8 } & \multicolumn{2}{|c|}{ PJ1 } & \multicolumn{2}{|c|}{ PJ2 } & \multicolumn{2}{|c|}{ PJ3 } & \multicolumn{2}{|c|}{ PJ4 } \\
\hline & Períodos & $\mathbf{C}$ & $\mathbf{S}$ & $\mathbf{C}$ & $\mathbf{S}$ & $\mathbf{C}$ & $\mathbf{S}$ & $\mathbf{C}$ & $\mathbf{S}$ & $\mathbf{C}$ & $\mathbf{S}$ & $\mathbf{C}$ & $\mathbf{S}$ & $\mathrm{C}$ & $\mathbf{S}$ & $\mathrm{C}$ & $\mathbf{S}$ & $\mathbf{C}$ & $\mathbf{S}$ & $\mathbf{C}$ & $\mathbf{S}$ & $\mathbf{C}$ & $\mathbf{S}$ & $\mathbf{C}$ & $\mathbf{S}$ \\
\hline \multirow{4}{*}{ 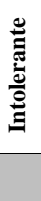 } & Trichoptera & 6 & 21 & 11 & 15 & 0 & 14 & 2 & 17 & 7 & 12 & 4 & 14 & 2 & 8 & 17 & 47 & 1 & 8 & 0 & 0 & 0 & 11 & 0 & 0 \\
\hline & Plecoptera & 2 & 5 & 0 & 0 & 2 & 1 & 0 & 0 & 0 & 0 & 1 & 4 & 0 & 0 & 0 & 0 & 0 & 0 & 0 & 0 & 0 & 0 & 0 & 0 \\
\hline & Ephemeroptera & 2 & 10 & 11 & 21 & 13 & 27 & 1 & 55 & 0 & 3 & 11 & 9 & 5 & 27 & 5 & 13 & 0 & 1 & 0 & 0 & 0 & 1 & 0 & 0 \\
\hline & Somatória & 10 & 36 & 22 & 36 & 15 & 42 & 3 & 72 & 7 & 15 & 16 & 27 & 7 & 35 & 22 & 60 & 1 & 9 & $\mathbf{0}$ & 0 & $\mathbf{0}$ & 12 & 0 & o \\
\hline \multirow{4}{*}{ 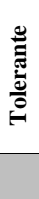 } & Coleóptera & 2 & 12 & 1 & 9 & 3 & 0 & 1 & 10 & 2 & 7 & 9 & 15 & 2 & 0 & 5 & 7 & 0 & 3 & 0 & 0 & 0 & 0 & 0 & 8 \\
\hline & Heteroptera & 0 & 0 & 1 & 3 & 1 & 0 & 0 & 2 & 2 & 3 & 0 & 0 & 0 & 0 & 0 & 0 & 0 & 0 & 1 & 0 & 0 & 1 & 0 & 3 \\
\hline & Odonata & 1 & 5 & 1 & 3 & 1 & 4 & 1 & 4 & 0 & 0 & 0 & 0 & 0 & 1 & 0 & 0 & 1 & 0 & 0 & 3 & 0 & 7 & 0 & 3 \\
\hline & Somatória & 3 & 17 & 3 & 15 & 5 & 4 & 2 & 16 & 4 & 10 & 9 & 15 & 2 & 1 & 5 & 7 & 1 & 3 & 1 & 3 & $\mathbf{0}$ & 8 & O & 14 \\
\hline \multirow{4}{*}{ 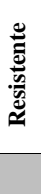 } & Díptera & 18 & 35 & 15 & 14 & 1 & 12 & 6 & 13 & 1 & 7 & 9 & 9 & 5 & 21 & 15 & 28 & 4 & 71 & 16 & 87 & 2 & 38 & 4 & 8 \\
\hline & Anellida & 0 & 1 & 0 & 1 & 0 & 4 & 0 & 0 & 0 & 3 & 0 & 0 & 0 & 5 & 0 & 0 & 0 & 23 & 8 & 35 & 2 & 17 & 4 & 1 \\
\hline & Mollusca & 0 & 1 & 4 & 1 & 0 & 0 & 7 & 3 & 0 & 0 & 0 & 0 & 0 & 1 & 0 & 1 & 0 & 5 & 1 & 8 & 0 & 3 & 2 & 3 \\
\hline & Somatória & 18 & 37 & 19 & 16 & 1 & 16 & 13 & 16 & 1 & 14 & 9 & 9 & 5 & 27 & 15 & 29 & 4 & 99 & 25 & 130 & 4 & 58 & 10 & 12 \\
\hline
\end{tabular}

Os resultados obtidos na avaliação de bioindicadores apontam a presença de táxons intolerantes em todos os pontos do córrego Bandeirinha. O maior número foi encontrado nos pontos PB2 e PB8 nos períodos chuvoso e seco e PB4 no período seco, indicando condições ambientais favoráveis para espécies sensíveis às alterações ambientais. Os indivíduos tolerantes e resistentes foram também encontrados nos períodos chuvoso e seco em todos os pontos de amostragem, com maior número de taxas para tolerantes nos pontos PB1, PB2, PB4 e PB6 no período seco. A menor riqueza e diversidade foi encontrada no ponto PB8 próximo ao exutório do córrego Bandeirinha.

A presença da maioria dos grupos taxonômicos $(\mathrm{N}=33)$ das Ordens Ephemeroptera, Plecoptera e Trichoptera (EPT) nas amostragens de invertebrados bentônicos evidenciaram ambientes com melhor qualidade ambiental. As características de ambientes lóticos com corredeiras na maioria dos pontos amostrados auxiliaram na abundância e ou riqueza da maioria dos táxons.

A qualidade ambiental dos pontos no córrego Bandeirinha pode ser verificada pela presença nos pontos PB1, PB3 e PB6 do gênero Anacroneuria (Plecoptera) que vive apenas em locais que apresentam boa qualidade da água. Nos pontos PB2 e PB3 foram registradas as maiores quantidades de táxons sensíveis Leptophlebiidae e no PB4 a maior presença de Ephemeroptera.

O tipo de substrato registrado em todos os pontos, conforme caracterização granulométrica foram areia e cascalho, favorecendo a presença de táxons mais sensíveis, como Ephemeroptera, Trichoptera e Plecoptera. Substratos formados por cascalhos e folhas apresentam as maiores riquezas, pois suportam uma maior quantidade de macroinvertebrados. (Pierre e Kovalenko, 2014; Dias-Silva et al. 2013).

No córrego Josefa Gomes em todos os pontos predominaram táxons resistentes. Os pontos PJ3 e PJ4 no período chuvoso apresentaram somente indivíduos resistentes, dos filos Anellida (classe: Oligochaeta) e Mollusca (classe: Gastropoda) indicando alterações antrópicas relevantes.

A não ocorrência espaço-temporal de alguns táxons registrados entre os 12 pontos amostrados (córregos Bandeirinha e Josefa Gomes) pode estar relacionada a capacidade de colonização dos grupos amostrados, com influência dos distúrbios gerados. 
$\mathrm{Na}$ relação granulométrica e biótica a heterogeneidade da composição física do sedimento pode ter influenciado na colonização em ambas drenagens, mas tendo maior influência no córrego Josefa Gomes, com o menor número de táxons e indivíduos colonizadores.

Os teores de sólidos voláteis para ambas drenagens indicam a distribuição e colonização no número de registros de táxons, evidenciando a maior influência no período seco com maiores registros de riqueza. Os maiores resultados de sólidos voláteis presentes nos sedimentos amostrados são os do córrego Josefa Gomes, inserido no ambiente urbano, onde percebe-se a relação com os bioindicadores pela ausência de táxons intolerantes e baixo resultados para táxons tolerantes, evidenciado no ponto PJ4. Os sólidos voláteis em sedimentos são indicativos indiretos de matéria orgânica de origem antrópica proveniente de lançamento de efluentes de forma contínua nesta drenagem.

\section{CONCLUSÕES}

Deve-se ressaltar que todas as áreas dos pontos amostrados possuem passivos ambientais gerados pelas atividades antrópicas, que contribuem de forma significativa para as alterações na qualidade da água, seja por áreas de preservação permanente desprovidas de cobertura vegetal, lançamentos de efluentes e resíduos sólidos, ou por atividades agropastoris. O córrego Bandeirinha, inserido em área rural do município, mesmo com os impactos gerados pelas atividades agropastoris, apresentou menores alterações na qualidade da água amostrada, em comparação com o córrego Josefa Gomes, inserido em ambiente urbano, onde os impactos gerados alteraram a qualidade da água nesta drenagem, e neste córrego predominaram táxons tolerantes e resistentes à poluição.

No córrego Josefa Gomes é visível a ausência da vegetação ciliar, pois grande parte das formações vegetais foi removida para propiciar, inicialmente, a prática da agropecuária e posteriormente, dar lugar à expansão urbana do município. É possível verificar que ao longo do córrego, existe lançamentos de efluentes, ocupações no fundo de vale, lançamento de resíduos sólidos, desenvolvimento de processos erosivos, assoreamentos, dentre outros impactos, intensificados pelos processos de uso e ocupação do solo na área urbana.

Os resultados demostram a distinção entre as alterações na qualidade da água em ambiente rural e urbano, e a relação dos bioindicadores com os sedimentos de corrente. $\mathrm{O}$ estudo auxilia na interpretação das alterações na qualidade da água além de contribuir com a geração de dados sobre as duas drenagens da região. A análise por meio dos bioindicadores bentônicos pode ser associada a análises físico-químicas e geoquímicas da água e dos sedimentos, proporcionando uma melhor interpretação dos resultados, para determinar a qualidade da água em drenagens superficiais.

A legislação brasileira, mais especificamente a Resolução CONAMA 357/2005, classifica as drenagens superficiais, por meio dos padrões e valores máximos e mínimos permitidos para os parâmetros físico-químicos, não considerando as informações da dinâmica de interação dos organismos bioindicadores de qualidade de água. Contudo os órgãos ambientais, já solicitam dos empreendimentos, relatórios de qualidade de água em programas de monitoramento, que contenham além dos parâmetros físico-químicos de qualidade, indicação biológica para drenagens superficiais. É previsível que a legislação se atualize, direcionando uma metodologia que contemple a inter-relação da qualidade da água entre os parâmetros físico-químicos e os bioindicadores.

\section{AGRADECIMENTOS}

Os autores agradecem aos técnicos, professores e alunos do Laboratório de Geoquímica da UnB e ao Instituto Federal de Educação Ciência e Tecnologia Goiás - IFG, ao CNPq e a CAPES. 


\section{REFERÊNCIAS BIBLIOGRÁFICAS}

APHA, AWWA, WPCF. Standard Methods for the Examination of Water and Wastewater, 20th Ed; Washington, 1999. 1496 p.

BRASIL. Resolução CONAMA 357, de 17 de março de 2005. Dispõe sobre a classificação de corpos de água e diretrizes ambientais para o seu enquadramento, bem como estabelece as condições e padrões de lançamento de efluentes, e dá outras providencias. Diário Oficial da União, Brasília, DF, n.53, 18 de maçro de 2005. Seção 1, p.58-63.

BELMEJO, L.; MARTOS. H. L; Utilização de Xiphophorus helleri como bioindicador de poluição hídrica de derivados de petróleo em condições tropicais. Revista Eletrônica de Biologia, v 1, n. 2, p. 1-17, 2008.

BORISKO. J. P; KILGOUR. B. W; STANFIELD. W. F; JONES. C. An Evaluation of Rapid Bioassessment Protocols for Stream Benthic Invertebrates in Southern Ontario, Water Qual. Res. J. Canada, v. 42, nº. 3, p. 184-193, 2007.

CALLISTO, M; GOULART, M.; MEDEIROS, A.O.; MORENO,P.; ROSA,C.A. Diversity assessment of benthic macroinvertebrates, yeasts and microbiological indicators along a longitudinal gradient in Serra do Cipó, Brazil. Braz. J. Biol., v. 61, no .2, p, 259-266, 2004.

CALLISTO, M; MORENO, P.; Bioindicadores como Ferramenta para o Manejo, Gestão e Conservação Ambiental, In: II ${ }^{\circ}$ SIMPÓSIO SUL DE GESTÃO E CONSERVAÇÃO AMBIENTAL, URI/Campus de Erechim. Anais Erechim/RS, 2006.

CARVALHO, E. M. \& UIEDA, V. S. Colonização por Macroinvertebrados Bentônicos em Substrato Artificial e Natural em um Riacho da Serra de Itatinga, São Paulo, Brasil. Revista Brasileira de Zoología, v. 21, n. 2, p. 287-293, 2004.

CHALAR, G. Composición y abundancia Del zoobentos Del Arroyo Toledo (Uruguay) y su relación com La calidad de agua. Revista Chilena de História Natural. v. 67, p. 129$141,1994$.

COLPO K. D; BRASIL M.T; CAMARGO. B.V; Macroinvertebrados bentônicos como indicadores do impacto ambiental promovido pelos efluentes de áreas orizícolas e pelos de origem urbana/industrial. Revista Ciência Rural, v. 39, n. 7, p. 2087-2092, 2009.

DIAS-SILVA. K; CABETTE. H.S.R; GIEHL.N.F.S; JUEN.L. Distribuição de Heteroptera Aquáticos (Insecta) em Diferentes Tipos de Substratos de Córregos do Cerrado Matogrossense. EntomoBrasilis v.6 n.2 p. 132-140. 2013.

ENVIRONMENTAL PROTECTION AGENCY: EPA United States, Rapid Bioassessment Protocols for Use in Streams and Wadeable Rivers: Periphyton, Benthic Macroinvertebrates, and Fish. Disponível em: <http://water.epa.gov/scitech/monitoring/rsl/bioassessment/> Acesso em: 22 de maio de 2013. 
FARIA, A. Estratigrafia e Sistemas Deposicionais do Grupo Paranoá nas Áreas de Cristalina, Distrito Federal e São João d'Aliança - Alto Paraíso de Goiás. 1995, $199 f$. Dissertação (Mestrado em Geologia) - Instituto de Geociências, Universidade de Brasília, Brasília, 1995.

HAUER, F. R. \& RESH. V. H. Benthic macroinvertebrates. In: Methods in Stream ecology. San Diego: Academic Press, 1996. p. 339-369.

INSTITUTO BRASILEIRO DE GEOGRAFIA E ESTATÍSTICA - IBGE, Censo 2012. Disponível em: <http://www.censo2012.ibge.gov.br/resultados_do_censo2012.php>. Acesso em: 27 agosto de 2012.

MÄENPÄÄ, K.A; SORMUNEN AJ; KUKKONEN JV. Bioacumulation and toxicity of sediment associated herbicides (ioxynil, pendimethalin and bentazone) in Lumbriculus variegates (Oligochaeta) and chironomus riparius (Insecta). Ecotoxicology and Environmental Safety, v. 56 n.3, p. 398-410, 2003.

MAGURRAN, A. E. Ecological Diversity and Its Measurement. Princeton Universidad Press, New Jersey, 1988. 179 p.

MILESI, S.V.; BIASI, C.; RESTELLO, R.M; HEPP, L.U; Efeito de metais cobre (Cu) e Zinco ( $\mathrm{Zn})$ sobre a comunidade de macroinvertebrados bentônicos em riachos do sul do Brasil. Acta Scientiarum. Biological Sciences, v. 30 n.3, p.283-289, 2008.

MUGNAI, R.; NESSIMIAN. J.L.; BAPTISTA. D.F. Manual de Identificação de Macroinvertebrados Aquáticos do Estado do Rio de Janeiro. Rio de Janeiro: Technical Books, 2010.

PIMENTA, S.M.; PEÑA. A.P.; GOMES. P.S. Aplicação de métodos físicos, químicos e biológicos na avaliação da qualidade das águas em áreas de aproveitamento hidroelétrico da bacia do Rio São Tomás, Município de Rio Verde - Goiás. Sociedade \& Natureza, Uberlândia, v, 21 n. 3 p. 393-412, 2009.

PIERRE, J. I., and KOVALENKO. K. E. Effect of habitat complexity attributes on species richness. Ecosphere v.5 n. 2. 2014.

RIBEIRO, L.O.; UIEDA, V.S. Estrutura da comunidade de macroinvertebrados bentônicos de um riacho de serra em Itatinga, São Paulo, Brasil. Revista Brasileira de Zoologia, v. 22, n.3, p. 613-618, 2005.

SOUZA, J.D. (Coord.). Carta Geológica do Brasil ao Milionésimo: Folha Brasília SD 23. Brasília: CPRM. 2004.

YOKOYAMA. E; PACIENCIA. G.P; BISPO P.C OLIVEIRA L.G; BISPO P.C. A sazonalidade ambiental afeta a composição faunística de Ephemeroptera e Trichoptera em um riacho de Cerrado do Sudeste do Brasil; Revista Ambiência Guarapuava, Paraná v.8 n. 1 p. 73 - 84. 2012. 
GEOCHEMICAL AND BIOINDICATORS MODEL TO EVALUATION OF WATER QUALITY.

PIMENTA, Sandro Morais; BOAVENTURA, Geraldo Resende RIBEIRO, Tiago Godoi; PEÑA, Alfredo Palau.

Artigo formatado para submeter ao periódico: Environmental Monitoring And Assessment. 


\title{
GEOCHEMICAL AND BIOINDICATORS MODEL TO EVALUATION OF WATER QUALITY.
}

\begin{abstract}
The interaction dynamism between the biotic and the anthropic environment determines the water quality in the surface drainage. The evaluation focusing in only one of these aspects, reveals uncertainty in the results when we consider the interaction dynamism that is not showed. With the scope to improve the interpretation about quality, it is of paramount importance to have an integrated pattern found in the weight evidence among the results of: physicochemical determination, sediments studies with the mineralogical determination and the usage of bioindicators. Streams Bandeirinha and Josefa Gomes were chosen to be samples of the pattern. Both located in the city of Formosa, Goias, Brazil. The Stream Bandeirinha is in the rural area and the Josefa Gomes, in the urban area, of the city. The choice was made due to both streams are in different environment but in the same region. The pattern was validated by the individual answers of the used methods, also by the difference of urban and rural environment and the rainy and dry seasons. The get together of the methods helped to identify the water quality with a small amount of score samples, shortage of price and analysis time. The pattern is showed satisfactory to be applied on both rural and urban environment and, furthermore, it helps in the identification of endangered areas and also, it can be used to implement conservation measures, protection and environmental managing policy.
\end{abstract}

Keywords: Weight evidence, Pattern, Geochemical, Bioindicators, Metals.

\section{INTRODUCTION}

The application of the physicochemical parameters is common in projects related to the water quality evaluation. Those determinations can be complemented with sediments or even the bioindicators utilization. Even if the physicochemical analysis shows the water condition, the ideal method is to associate this to the other biological methods allowing a more completed characterization with the biological and the physical environment, usually useful to manage the hydric sources (Ribeiro e Uieda 2005). The bioindicators has been considered efficient indicators of water quality with low costs.

The problems in the data and failures of monitoring networks intensifies the research for establishing effective methods, reliable, inexpensive and runtime, that shows the real situation of the studied area. Each evaluation method presents some limits of interpretation utilization and due to that, it is necessary to use the methods integrations to consolidate the quality studies. According to Rodriguez et al (2014) in the last few years, the political and technical factors with the quality modelling water, monitoring of nutrients and sediments, pesticides and pollutants in the ponds and rivers influenced in the environmental policy changes.

Le et al (2014) emphasizes that the efficiency of the decision-making regarding water quality management is fundamental to reduce financial and environmental costs. The authors suggest in their study a quality model of water pattern with the sensibility and unsureness analysis and with a management domination including the loss estimative and the data value analysis. Consequently going beyond the minimum and maximum values determined by the environmental organizations of water quality. 
Reichert and Vanrolleghem (2001) put in evidence that the pattern of water quality helps in interpreting the results. These pattern have many parameters and raises the question of how many of them can be set in one certain context and how we can find a sub complex of parameters that shows the water quality in evidence. Those patterns can be used to foresee the systems or answers to immediate changes nowadays.

Reichert and Vanrolleghem (2001), will make the uncertainty analysis based on the pattern water quality in rivers, the RWQM1. They consider that the uncertainty reduction applied to the modelling can be done through improvements of experimental projects with more dynamic conditions or even with quantification measures such as the wood benthic quantification.

Budka et al (2010) had studied the predictable water pollution pattern using bioindicators data for the sea water. They concluded that the bioindicators can be used with a highly success to differ the different levels of water poisonousness, even though they are in small amount of available data. The bioindicators choice influences the performance of built models and it is linked with the financial aspect. They also emphasizes that for some reasons to develop cheaper patterns, but not precisely, would be perfect, meanwhile for other purposes the pattern accuracy would be the most important factor, besides the cost.

Mier et al (2013) proposed an integrated system of sediments evaluation using the chemical analysis of sediments, the water quality, bioevaluation and bioindication with fish in hydrocarbons contaminated area in Midwestern US. With the results of that experience they determined, if the contaminated area could have been included to the national priority list for more effective protection measures.

Other studies such as the one with Benedetti et al (2011) tried to search the integration between the developed approach to get a multidisciplinary characterization that matched different studies, using the weight evidence in their approaches to classify the polluted sediments, integrating the sediments chemistry, bioavailability, bioindicators and biotests. They had as a scope to confirm the sensibility and the importance of a multitask evaluation of the sediments quality.

Benedetti and al (2011) points out that the methodology application of the evidence weight has been largely used with environmental risks evaluation procedures. Besides the fact the evidence line was chosen, it means that, different studies and data integration differ depending on the objective or sites, the multitask approach given helps to a better interpretation.

Linkov et al (2009) states that the integration approach made to synthetize the different studies or evidence lines, can even be in questions of numbers or quality, to an integrated evaluation of it, changing or risks. The simplest quality methods are the interpretation of different results, as long as the quantities approaches are based on math structures and statistics elaboration, producing reports for each one of the evidence line and for its global integration.

Although not a standardized procedure, the development of models for comparison and aggregation of heterogeneous data for quantitative methods can count on the allocation of weights, 
thresholds, indexing criteria, classification of points, compared to reference conditions and regulatory functions (Dagnino et al, 2008; Linkov et al., 2009; Semenzin et al., 2008; Suter and Cormier, 2011; Benedetti et al 2011).

To get all the results together in a method set: physicochemical parameters determination, the sediment studies and the bioindicators application, it is proposed an integrated model that gives data in numbers, index criteria and weight in the results interpretations that corresponds the evidence lines.

\section{MATERIALS AND METHODS}

\section{Study area}

The proposed method was studied in two shallow process of underdrainage: stream Bandeirinha, located in the rural area and stream Josefa Gomes, in the urban area, both located in Formosa, Goias, Brazil. The choice was made due to the fact they were in different environment, producing the typical answers in the method application. The population of the city consists in 100.085 habitants (IBGE, 2012). The combined agriculture and the stock raising is one of the most important activities in the city giving importance to the stock raising and dairy.

The city has climate defined by a dry season from May to September, and the other humid with torrential rains in the months from October to April. The average annual rainfall is $1.485 \mathrm{~mm}$, concentrating mainly in the months from October to April. During June and July rainfall is virtually absent, the annual average temperature around was between $21,5^{\circ} \mathrm{C}$. The area of Formosa is consisted in Proterozoic rocks represented by the Group Paranoa and it is about the Mesoproterozoic age and also the Group Bambui, Subgroup Paraopeba that is about the Neoproterozoic age, furthermore Detrituslateritic coverages from the tertiary-quaternary period, and recent alluvial soils in the borders of the water courses (Souza et al 2004).

Sedimentological studies of rocks from the Paranoa and Bambui groups points out that they came from different tectonics contexts and the sediments came from different source-rocks. The Paranoa Group is formed by the quartzite and piles with also the minor participation of arkoses, glauconitic quartzite and carbonates, meanwhile the terrigenous rocks of the group Bambui are rich in mica ground and clay. Mica (muscovite and biotite) are diagenetic altered to chlorites and ilite or they have the phengite composition. The composition and texture of the ferrous chlorites indicates a substitution of mafic minerals or they represent the esmectitas trioctahedral diagenetic evolution (Guimaraes 1997).

The stream Bandeirinha is used to supply the city and it is in the rural area, it's $42 \mathrm{~km}$ far Northway receding in Parana River and it is belonged to the Rio Tocantins Bay. The Stream Josefa Gomes is completely inside the urban area with 7,5 km far Southwest way and it starts at Mata da Bica City Park. There is a slight difference in the distance and it is about $1,5 \mathrm{~km}$ far then, it runs for $6 \mathrm{~km}$ and recedes again in Lagoa Feia.

The highest part of the Bandeirinha basin, in the source area (elevation of 1.095 meters) is located in the rock of Paranoa Group. In the middle and low regions toward the Rio Parana (elevation 
of 612 meters) predominates the rocks of Bambui Group. Meanwhile the stream Josefa Gomes is completely inserted in the rocks of Paranoa Group.

It was determined 08 spots in stream Bandeirinha and 04 spots in stream Josefa Gomes. The spots selection was done based on the anthropic activities during the drains and the stream incidence. The 08 spots in stream Bandeirinha and the 04 ones in stream Josefa Gomes follow the source of the river until the recedes, Figure 01. The results were collected within the months of January and September 2013 according to the rainy and dry seasons in the region

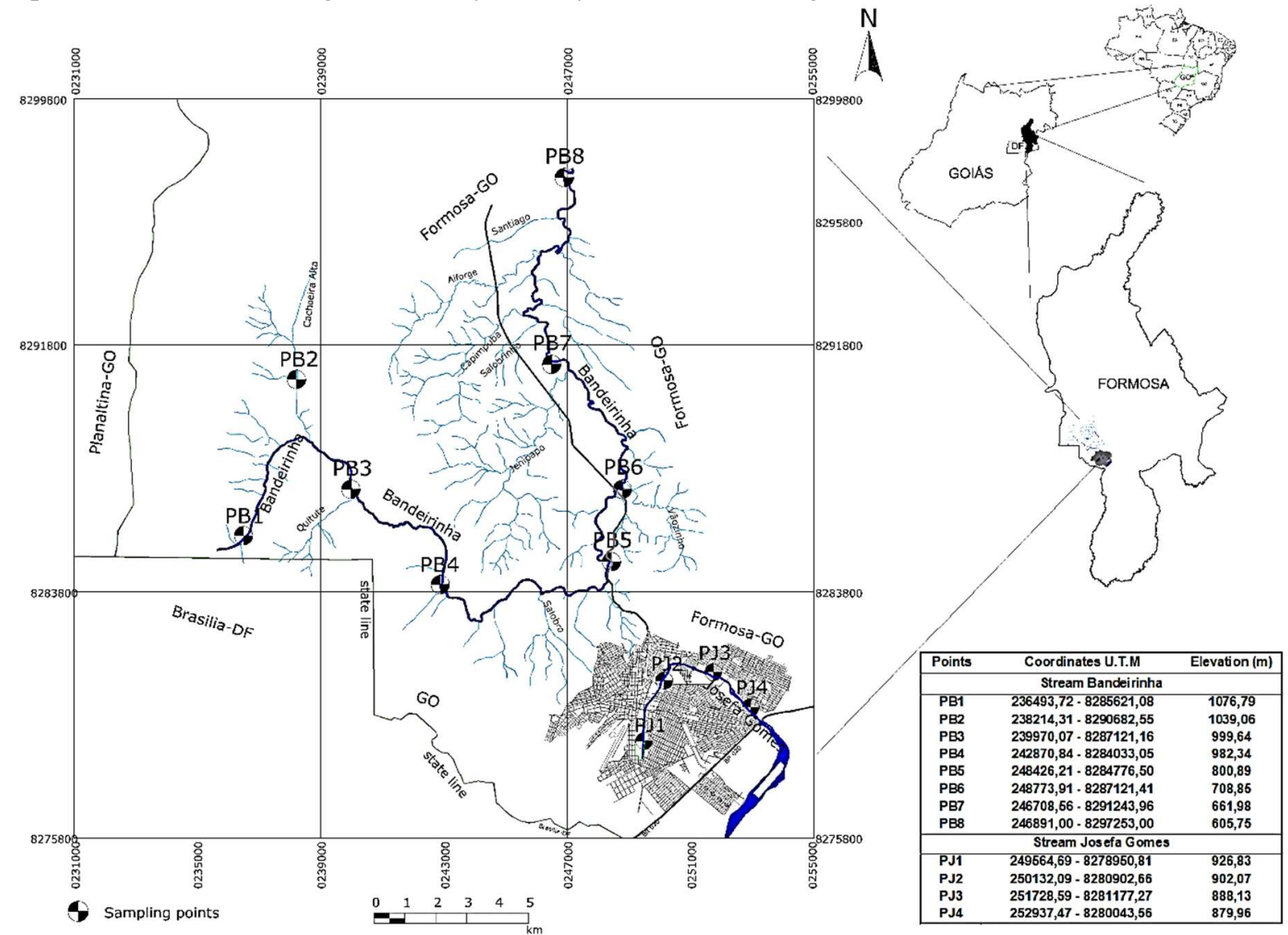

Figure 1. Location of the area, stream sampling points Bandeirinha and Josefa Gomes, Formosa-GO. Source: IBGE 2012 Final Organization, Pimenta 2015.

All the procedures were done in the Laboratory of Geochemistry and of X-ray of Institute of Geosciences at UnB, in the Laboratories the Institute Federal de Goias - IFG and also in the Laboratory de Campo: Centro de Tecnologia Agricola e Ambiental Ltda. The methodologies used in the chemical analysis were based on Standard Methods for Examination of Water and Wastewater; 20th edition of American Public Health Association (APHA), of American Water Works Association (AWWA) and of the Water Pollution Control Federation (WPCF).

The analytical control of the results were validated by samples of international pattern of certification concentration. To the water it was used the standard of the label Canada NWRI (National Water Research Institute) ION -915 and MIRAMICHI-02. It was also used as a parameter the distilled water, besides the ionic balance according to Logan (1965). To the sediment analysis it was used the NIST parameter (National Institute for Standards and Technology - USA) SEM 2709 a San Joaquin 
Soil. To the standardization of the digestion and analysis methodology, it was also used a $\mathrm{C}$ pattern of basalt rock (Boaventura e Hirson, 1987). The analytical curves were determined by Atomic Absorption Spectrometry (AAS); and the Inductively Coupled Plasma Optical Emission Spectrometry (ICP/OES), and the Ionic Chromatographic (IC) that were prepared with pattern solutions of $1000 \mathrm{ppm}$ from Vetec. From this point on the necessary dissolutions for each element were made.

\section{Physicochemical determinations}

It was collected water samples in the 12 spots, polyethylene bottle $1 \mathrm{~L}$, purified water were used to the experience and they had been washed with nitric acid $10 \% \mathrm{v} / \mathrm{v}$ by the Milliq system (resistivity $18,2 \mathrm{M} \Omega \mathrm{cm}^{-1}$ to $25^{\circ} \mathrm{C}$ ). The determinations of the $\mathrm{pH}$, Temperature, Electrical Conductivity and Total Dissolved Solid were carried through, by using the multiparameter (Hach model, Sension 378), the Dissolved Oxygen was determined by Microprocessed Oximeter (OMC-900 model). The Turbines, Color and $\mathrm{NH}_{3}$ were determined by colorimetric techniques with spectrophotometer Reading (Hach DR 2000 model).

The samples were filtered by cellulose membrane with a pore of $0,45 \mu \mathrm{m}$. The determination of $\mathrm{Na}$ and $\mathrm{K}$ were made using an Atomic Absorption Spectrometry (Perkin Elmer model, Analyst 200) with air-acetylene fire. The anions: $\mathrm{F}^{-}, \mathrm{Cl}^{-}, \mathrm{NO}_{3}{ }^{-}, \mathrm{PO}_{4}{ }^{3-}$ and $\mathrm{SO}_{4}{ }^{2-}$ were determined by ionic chromatography with suppressed conductivity (Dionex, ICS90 model). The alkalinity was determined by the titulometric method with $\mathrm{H}_{2} \mathrm{SO}_{4}$ per $0,01 \mathrm{M}$ standadizated with $\mathrm{NaOH} 0,05 \mathrm{M}$, using automatic titrator (Schott model, Titroline easy). The data were treated with the Spearman (R) correlation, procedure used by (Carmo et al 2005; Poudel et al 2013; Zhang, et al 2013).

\section{Watercourse sediments}

The collection and analysis of the sediments samples were followed by the work of (Boaventura and Moreira, 2003: Maia et al, 2005, Mulholland et al, 2012). It was collected about $1 \mathrm{~kg}$. After the drying process, the samples were separated and went through riddles series in the following orders: 10 $\mathrm{mm}-5 \mathrm{~mm}-2,5 \mathrm{~mm}-0,8 \mathrm{~mm}-0,5 \mathrm{~mm}-0,125 \mathrm{~mm}-0,1 \mathrm{~mm}$ for a granulometric characterization. The material in passing $0,8 \mathrm{~mm}$ sieve was divided into two subsamples. One was reserved for mineralogical determination and another, last in nylon sieve to separate the smallest fraction that $63 \mu \mathrm{m}$ used in the determination of metals.

The sediments mineral composition evaluation were achieved by X-Ray Diffractometric (XRD), in four remnants: one of the total sample $(\mathrm{t})$ and four from the potter fraction: oriented and dried in the air (n), with ethilenoglicol (g), glycerol (gl) and warmed (a). It was used the Rigaku machine model DMAXB with the $\mathrm{CuK} \alpha$ radiation, speed of the remnant about $2 \%$ min and with the interval about $0,05^{\circ}$. The interval of the remnant was approximately about: 2 to $65^{\circ}$ for $\mathrm{t}$, from 2 to $35^{\circ}$ for $\mathrm{n}$ and from 2 to $35^{\circ}$ or 2 to $25^{\circ}$ for $\mathrm{g}, \mathrm{gl}$ and respectively. The interpretations of the difratogram were made in JADE software 3.0 Windows, XRD Pattern Processing for the PC, 1991-1995 Materials Data, Inc. 
It was also used the samples attacks with the Lithium meteorite fusion $\left(\mathrm{LiBO}_{2}\right)$, going through a digestion process so that the metals could be available in solution. (Boaventura 1991), used in the major elements determinations: $\left(\mathrm{SiO}_{2}, \mathrm{Al}_{2} \mathrm{O}_{3}, \mathrm{Fe}_{2} \mathrm{O}_{3}, \mathrm{CaO}, \mathrm{MgO}, \mathrm{TiO}_{2}, \mathrm{Na}_{2} \mathrm{O}, \mathrm{K}_{2} \mathrm{O}\right.$ ), with the results in a $100 \%$. For the elements determination it was used the digestion via acid through the method of aqua regia $\left(\mathrm{HNO}_{3}+3 \mathrm{HCl}\right)$ and afterward readings of the elements: $(\mathrm{Ba}, \mathrm{V}, \mathrm{Cr}, \mathrm{Mn}, \mathrm{Cu}, \mathrm{Zn}, \mathrm{P}, \mathrm{Pb}$ ). The readings were made based on the ICP/OES (Spectroflame model, FVM03).

\section{Bioindicators identification}

It was used as bioindicators the benthonic invertebrates, collected with a Surber sample type with flexible steel outfit, with nylon fabric $250 \mu$ of opening, dimensions of $30 \times 30 \times 60 \mathrm{~cm}$, making 5 replicas of collection per spot. After the collection the benthos were put individually in conditioning apparatus and rested in plastic glasses immersed in alcohol $80 \% \mathrm{v} / \mathrm{v}$, for the identification and counting of taxon's met, following the work of (Borisko et al 2007; Callisto et al 2004; Pimenta et al 2009; Mugnai et al 2010).

The taxons identification is done by the stereoscope binocular magnifier glass. The bioindicators were divided into (Callisto et al 2004; Pimenta et al 2009) three groups according to its tolerance: sensitiveness organisms or intolerants (Trichoptera representants, Plecoptera, Ephemeroptera) tolerant organisms (Coleoptera, Heteroptera and Odonata) and resistant organisms (Diptera, Oligochaeta).

\section{Integration Model}

The models elaboration that search for the dissimilar data integration of the environmental analysis, is in evidential in many studies (Dagnino et al, 2008; Lenkov et al, 2009; Semenzin et al., 2008; Benedetti et al 2011). These models can be elaborated for specific applications without precise values, besides that the general evidence of the tendencies of a parameter set the decision of various criteria of analysis of the evidence line side, to obtain a diagnostic with fundamental better results reducing cost and time.

The proposed model was found in the evidence weight, according to Linkov (2009) that can be defined by a synthase of different evidences lines using methods that are qualitative or quantitative, to develop conclusions about questions related to the commitment degree or environmental risks.

The model uses numerical values and weight attributions and index criteria in the interpretation of the results that correspond with the evidence lines, using: the physicochemical determinations; the sediments studies; the bioindicators identification. The diversity of applied environmental analysis methods makes room for complexities that are guided using an explicit process when it comes to weight evidence. The weights are attributed for each answer of the interpretation of the results, and they are based on the logic implication, strength and data quality. For each one of the applied methods, the results interpretations give the evidence lines, and are used in the integration model. 
In the physicochemical determinations results are considered the interpretations such as:

- More effective standardization in the physicochemical parameters in relation with the others points;

- The correlation between parameters indicating the changing of anthropic origin

- Standardization in the physicochemical parameters indicating anthropic activities

\section{In the results of sediments determinations:}

- Composition changing in the natural granulometric sediments;

- Non-proper determinations with the local geology;

- The presence of major elements and anthropic origin traces.

\section{In the Bioindicators identification:}

- Reduced or absence of intolerant organisms;

- Reduced or absence of intolerants and tolerant organisms;

- Predominance resistents organisms.

The physicochemical determinations and the bioindicators identification are related to the hydrologic period (HP) and answers with different forms and seasoning, so this variant was inserted in the pattern. The climatic seasonality is an important factor to physicochemical determinations and the variations influences directed in the concentration and in the elements actions in the environment. In the dry season there are the elements concentration, while in the pluvial period there is a dilution and the material carrying effect to the superficial drainage. There were attributed some non-dimensions values of 0,2 to the pluvial period, considering the dilution and 0,3 to the dry period, considering the concentration and consequently more standardization. In the identification of the bioindicators the dry and pluvial periods also influence in the distribution of these organisms in its habitat. In the dry periods there is a more effective fixation of the organisms, consequently more richness and diversity, while in the pluvial one there is less richness and diversity. The nondimensional values considered were 0,3 for the raining period and 0,2 to the dry one.

Suter (2011), clarifies that when you develop individual evidence lines from the available data to approach one specific question, it is required one degree of description that those evidence lines support one conclusion or alternative. In this line of thinking in the present model, in weighting the evidences, the flexibility derives from a quantitative analysis by using a score system of pre-defined criteria. This procedure follows in an inferential manner with the scope to be defined very clear as if it were a statistic test or a math model. The answers to these interpretations of each method received a grade (g) according an arbitrary scale ( 0 to 5 ). When the interpretation of the results are tending to $\leq 0$ there will be a less relation with the answer, $\geq 5$ relations with a strong interpretation answer.

The interpretation of the results are classified per weight considering the analysis influence that composes the method (0,5 to 2). Eventually, it was added the variation from the hydrolytic period (HP). The sum of the grades $\left(\sum \mathrm{g}\right)$ multiplied by the weights $(\mathrm{W})$ and by the hydrolytic period (HP) comes to a partial score, for each results interpretation. The math below is expressed to the physicochemical determinations and the bioindicators answers: 


\section{PARTIAL SCORE $=\Sigma \mathrm{G} \times \mathrm{W} \times \mathrm{HP} *$}

G: Graded between 0 to 5 to the results interpretations

W: Weight of each interpretation

HP: Hydrologic period and physicochemical determinations $(0,2$ to raining period $-0,3$ to the dry period);

HP: Bioindicators hydrologic period ( 0,3 to the raining period $-0,2$ to the dry one)

To the sediments studies, the math is the same, and it is not attributed the variation to the hydrologic period because this one has less influence in the results of this method. The Table 1, summarizes the relations between the results and the interpretation, applying the intensity and weight.

\section{PARTIAL SCORE $=\Sigma \mathbf{G} \times \mathbf{W}$}

G: Graded between 0 to 5 to the results interpretations

W: Weight of each interpretation;

Table 1: Logic Diagram of the evidence relation in applying the model

\begin{tabular}{|c|c|c|c|}
\hline Method Applied & WEIGHT & $\begin{array}{c}\text { Interpretation of Results } \\
\text { (Intensity } 0 \text { to 5) }\end{array}$ & Calculation Applied \\
\hline $\begin{array}{c}\text { Physicochemical } \\
\text { analysis }\end{array}$ & $\begin{array}{l}1,5 \\
2\end{array}$ & $\begin{array}{l}\text { More effective standardization in the physicochemical } \\
\text { parameters in relation with the others points; } \\
\text { The correlation between parameters indicating the } \\
\text { changing of anthropic origin; } \\
\text { Standardization in the physicochemical parameters } \\
\text { indicating anthropic activities. }\end{array}$ & $\Sigma \mathrm{GPC} \times \mathrm{WPC} \times \mathrm{HPPC}$ \\
\hline Studies Sediments & $\begin{array}{c}0,5 \\
1,5 \\
2\end{array}$ & $\begin{array}{l}\text { Composition changing in the natural granulometric } \\
\text { sediments; } \\
\text { Non-Proper determinations with the local Geology; } \\
\text { The presence of major elements and anthropic origin } \\
\text { traces. }\end{array}$ & $\Sigma \mathrm{GS} \times \mathrm{WS}$ \\
\hline Bioindication & $\begin{array}{c}0,5 \\
1,5 \\
2\end{array}$ & $\begin{array}{l}\text { Reduced or absence of intolerant organisms; } \\
\text { Reduced or absence of intolerants and tolerates } \\
\text { organisms; } \\
\text { Predominance resistents organisms. }\end{array}$ & $\Sigma \mathrm{GB} \times \mathrm{WB} \times \mathrm{HPB}$ \\
\hline
\end{tabular}

After the definition of the partial scores by the analysis methods, they are going to be integrated following the below expression. Coming to a result with a final score of water quality.

\section{FINAL SCORE $=\Sigma$ GPC $\times$ WPC $\times$ HPPC $+\Sigma$ GS $\times W S+\Sigma$ GB $\times W B \times$ HPB \\ 3}

GPC: Graded between 0 to 5 to physicochemical answers

WPC: Weight of each physicochemical answer

HPPC: Hydrologic physicochemical period ( 0,2 to raining period $-0,3$ to dry period)

GS: Graded between 0 to 5 to sediments answers

WS: Weight for each sediment answer

GB: Graded between 0 to 5 to bioindicators answers

WB: Weight to each answer bioindicators

HPB: Hydrologic bioindicators period ( 0,3 to the raining $-0,2$ to the dry period) 
The determination of the score is done by the method of interpretation between the gained results, so that it can be checked and integrated in the evaluation methods of the water quality. The final classification of the sample score conditions are represented by the interval. Figure 2.

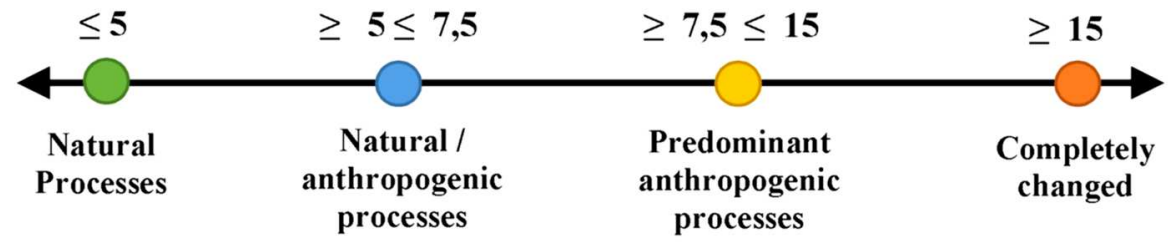

Figure 2: Interval to the final classification, integrating the analysis methods.

\section{RESULTS AND DISCUSSION}

\section{Physicochemical determinations results}

The results showed in the Table 02 makes clear the human impacts from the points PB5 to PB8 at Stream Bandeirinha, located near the urban area. These points show more parameters changing. In the dry period accentuates the variation in the $\mathrm{SO}_{4}{ }^{2-}$ in the $\mathrm{NO}_{3}{ }^{-}$and $\mathrm{Cl}^{-}$that has as source the sewage system of domestic houses, in those periods the results obtained to the $\mathrm{SO}_{4}{ }^{2-}$ of the PB1 to PB4 are below the detection limit.

Table 02: Physicochemical parameters in the pluvial and dry periods.

\begin{tabular}{|c|c|c|c|c|c|c|c|c|c|c|c|c|c|c|c|c|}
\hline \multicolumn{17}{|c|}{ STREAM BANDEIRINHA - PARAMETERS (rain) } \\
\hline \multirow{2}{*}{ Point } & \multirow{2}{*}{$\begin{array}{c}\mathbf{T} \\
{ }^{\circ} \mathbf{C}\end{array}$} & \multirow{2}{*}{$\begin{array}{c}\text { Color } \\
\text { UH }\end{array}$} & \multirow{2}{*}{$\begin{array}{c}\text { Turb } \\
\text { UT }\end{array}$} & \multirow{2}{*}{$\mathbf{p H}$} & \multirow{2}{*}{$\begin{array}{c}\text { C.E } \\
\mu \mathrm{s} / \mathrm{cm}\end{array}$} & TDS & D.O & Alkali & $\mathrm{NH}_{3}$ & $\mathbf{N a}$ & $\mathbf{K}$ & $\mathrm{SO}_{4}{ }^{2}$ & $\mathrm{PO}_{4}{ }^{3}$ & $\mathrm{NO}_{3}^{-}$ & $\mathrm{Cl}^{-}$ & $\mathbf{F}^{-}$ \\
\hline & & & & & & \multicolumn{11}{|c|}{$\mathbf{m g} / \mathbf{L}$} \\
\hline PB1 & 23 & 22 & 5 & 5,71 & 5 & 1,9 & 7,1 & 2,43 & $<\mathrm{LD}$ & 0,08 & 0,48 & $<\mathrm{LD}$ & $<\mathrm{LD}$ & 0,26 & 0,16 & 0,04 \\
\hline PB2 & 22,9 & 66 & 12 & 6,30 & 16,91 & 7,6 & 7,8 & 7,06 & 0,19 & 0,22 & 0,69 & 0,69 & 0,35 & $<\mathrm{LD}$ & 0,25 & 0,03 \\
\hline PB3 & 21,5 & 127 & 26 & 5,96 & 12,17 & 5,3 & 8,9 & 7,06 & 0,27 & 0,21 & 0,56 & 0,71 & $<\mathrm{LD}$ & 0,20 & 0,27 & $<\mathrm{LD}$ \\
\hline PB4 & 21,8 & 78 & 16 & 6 & 13,45 & 5,9 & 8,2 & 7,06 & 0,16 & 0,23 & 0,51 & $<\mathrm{LD}$ & 2,51 & 0,23 & 0,27 & 0,03 \\
\hline PB5 & 22,5 & 57 & 13,60 & 7,44 & 112,90 & 53,7 & 9,3 & 34,19 & 0,14 & 0,63 & 2,12 & 0,65 & 0,52 & 0,50 & 0,46 & 0,04 \\
\hline PB6 & 23,7 & 53 & 12,30 & 7,46 & 149,30 & 71,2 & 8,7 & 45,44 & 0,13 & 0,65 & 2,41 & 1,88 & $<\mathrm{LD}$ & 0,49 & 0,47 & 0,09 \\
\hline PB7 & 27,5 & 238 & 73 & 7,51 & 99,30 & 47,1 & 9,5 & 33,72 & 0,17 & 0,97 & 2,36 & 1,06 & $<\mathrm{LD}$ & 0,42 & 1,68 & 0,24 \\
\hline PB8 & 27,3 & 420 & 106 & 7,38 & 133 & 63,3 & 9,1 & 45,90 & 0,42 & 2,05 & 1,94 & 1,62 & $<\mathrm{LD}$ & 0,99 & 1,14 & 0,38 \\
\hline \multicolumn{17}{|c|}{ STREAM BANDEIRINHA - PARAMETERS (dry) } \\
\hline PB1 & 23,8 & 18 & 5 & 5,4 & 4,95 & 1,8 & 6,9 & 12,35 & 0,25 & 0,12 & 0,39 & $<\mathrm{LD}$ & 1,5 & 0,49 & 0,35 & $<\mathrm{LD}$ \\
\hline PB2 & 23,9 & 33 & 7 & 6,25 & 23,5 & 10,7 & 7,8 & 64,41 & 0,3 & 0,30 & 1,01 & $<\mathrm{LD}$ & 0,85 & 0,31 & 0,78 & $<\mathrm{LD}$ \\
\hline PB3 & 25,9 & 52 & 11 & 6,3 & 18,4 & 8,3 & 8,1 & 50,51 & 0,35 & 0,20 & 0,85 & $<\mathrm{LD}$ & 0,87 & 0,42 & 0,86 & 0,16 \\
\hline PB4 & 25,5 & 43 & 10 & 6,18 & 15,3 & 6,7 & 8,5 & 42,79 & 0,34 & 0,20 & 0,61 & $<\mathrm{LD}$ & $<\mathrm{LD}$ & 0,39 & 0,83 & 0,09 \\
\hline PB5 & 24,5 & 15 & 4 & 7,78 & 165,9 & 79,2 & 9,5 & 47,84 & 0,30 & 0,74 & 2,70 & 0,75 & $<\mathrm{LD}$ & 0,53 & 0,41 & $<\mathrm{LD}$ \\
\hline PB6 & 25,7 & 5 & 3 & 7,96 & 191 & 91,3 & 8,3 & 52,89 & 0,28 & 0,71 & 3,03 & 0,59 & $<\mathrm{LD}$ & 0,31 & 0,30 & 0,12 \\
\hline PB7 & 26,5 & 27 & 6 & 7,52 & 255 & 122,2 & 9,1 & 71,28 & 0,28 & 0,70 & 3,91 & 2,57 & 2,28 & 0,79 & 1,14 & 0,41 \\
\hline PB8 & 26,3 & 23 & 5 & 7,78 & 248 & 118,9 & 9,5 & 69,55 & 0,34 & 0,92 & 3,24 & 1,56 & 0,98 & 0,58 & 0,95 & 0,13 \\
\hline \multicolumn{17}{|c|}{ STREAM JOSEFA GOMES - PARAMETERS (rain) } \\
\hline \multirow{2}{*}{ Point } & $\mathbf{T}$ & Color & Turb & $\mathrm{nH}$ & C.E & TDS & D.O & Alkali & $\mathrm{NH}_{3}$ & $\mathbf{N a}$ & $\mathbf{K}$ & $\mathrm{SO}_{4}{ }^{2}$ & $\mathrm{PO}_{4}{ }^{3}$ & $\mathrm{NO}_{3}^{-}$ & $\mathrm{Cl}^{-}$ & $\mathbf{F}^{-}$ \\
\hline & ${ }^{\circ} \mathbf{C}$ & UH & UT & pH & $\mu \mathrm{s} / \mathrm{cm}$ & \multicolumn{11}{|c|}{$\mathrm{mg} / \mathrm{L}$} \\
\hline PJ1 & 22,6 & 49 & 11 & 6,45 & 57,10 & 26,80 & 7,2 & 15,66 & 0,11 & 3,65 & 0,70 & 1,12 & 1,29 & 0,32 & 1,37 & 0,04 \\
\hline PJ2 & 22,8 & 61 & 11,90 & 6,83 & 139,4 & 66,40 & 8,5 & 27,35 & 0,30 & 13,94 & 2,46 & 2,94 & $<\mathrm{LD}$ & 11,50 & 6,21 & 0,13 \\
\hline PJ3 & 23,9 & 27 & 2,60 & 6,95 & 129,7 & 61,70 & 9,5 & 34,63 & 0,06 & 9,55 & 2,02 & 2,25 & $<\mathrm{LD}$ & $<\mathrm{LD}$ & 3,81 & 0,12 \\
\hline PJ4 & 22,9 & 37 & 4 & 7,17 & 129,0 & 61,40 & 6,7 & 35,07 & 0,09 & 9,01 & 1,79 & 1,76 & $<\mathrm{LD}$ & 0,44 & 3,84 & 0,07 \\
\hline \multicolumn{17}{|c|}{ STREAM JOSEFA GOMES - PARAMETERS (dry) } \\
\hline PJ1 & 25,60 & 8 & 2 & 6,26 & 41,10 & 19,10 & 8,1 & 10,34 & 0,19 & 3,88 & 0,23 & $<\mathrm{LD}$ & $<\mathrm{LD}$ & 0,93 & 2,59 & 0,09 \\
\hline PJ2 & 25,80 & 40 & 8 & 6,61 & 151,10 & 72,10 & 7,7 & 26,55 & 1,67 & 15,30 & 2,50 & 3,81 & 0,60 & 8,37 & 9,07 & 0,14 \\
\hline PJ3 & 24,90 & 43 & 9 & 6,84 & 138,60 & 66,00 & 9,1 & 31,94 & 0,29 & 13,75 & 0,89 & 0,92 & $<\mathrm{LD}$ & 0,38 & 7,01 & $<\mathrm{LD}$ \\
\hline PJ4 & 25,90 & 34 & 7 & 7,48 & 133,50 & 63,50 & 8,6 & 31,74 & 0,23 & 12,06 & 0,96 & $<\mathrm{LD}$ & 1,25 & 0,51 & 6,90 & 0,24 \\
\hline
\end{tabular}

PS: The results are below the detention limit $(<\mathrm{LD})$; UH=Hasen Unit; UT=Turbid unit

The alkalinity was presented following the geological characteristics of the region that is sited in the Bambui series which is rich in carbonates. The values showed were cumulative, possibly coming from the dragging of the sediments and intemperism in the drainage borders. The results show that the 
points in stream Bandeirinha can suffer few changing in the quality of the water. The main changing occur in the low tide of the urban center of the village that is far about $5 \mathrm{~km}$ of the nearest tributary of the stream Bandeirinha, indicating the direct influence of the urban area about the drainage inserted in the rural area.

In Stream Josefa, as happens in stream Bandeirinha, it is realized that in the raining period there are more numbers to the color and turbidly parameters, and they are reduced in the dry season, while the other parameters show a high number due to the concentration of the elements. It makes salient that the PJ2 point located in the end of the right way, the parameters had more high values, in this point it was verified the presence of the $\mathrm{NH}_{3}(0,30 \mathrm{mg} / \mathrm{L})$ in the pluvial period and a major concentration in the dry period $(1,67 \mathrm{mg} / \mathrm{L})$, beyond the major values to the $\mathrm{SO} 42-$, NO3- and $\mathrm{Cl}$, during all rainy season and dry, indicating the domestics effluents contributions, and it showed a minor value observed to the dissolved oxygen - D.O (7,7 mg/L) in the dry period.

It is possible to verify that along the Stream Josefa Gomes effluents launching of effluents and solids residues, erosive processes, intensified by the use and occupation of the urban area in the land. The results of the physicochemical determinations were treated by means of the Spearman correlation and they are presented in the Table 3 and 4.

Table 3: Spearman correlation matrix between the physicochemical parameters in waters of the stream Bandeirinha, in the raining and dry time. Correlations that mean $\mathrm{p}<0,05$.

\begin{tabular}{|c|c|c|c|c|c|c|c|c|c|c|c|c|c|c|c|c|c|}
\hline & Time* & Temp & Color & Turb & pH & E.C & TDS & D.O & Alkali & $\mathrm{NH}_{3}$ & $\mathrm{Na}$ & $\mathbf{K}$ & $\mathrm{SO}_{4}{ }^{2}$ & $\mathrm{PO}_{4}{ }^{3-}$ & $\mathrm{NO}_{3}^{-}$ & $\mathrm{Cl}^{-}$ & $\mathbf{F}^{-}$ \\
\hline \multirow{2}{*}{ Temp } & $\mathrm{r}$ & 1 & & & & & & & & & & & & & & & \\
\hline & $\mathrm{d}$ & 1 & & & & & & & & & & & & & & & \\
\hline \multirow{2}{*}{ Color } & $\mathrm{r}$ & - & 1 & & & & & & & & & & & & & & \\
\hline & $\mathrm{d}$ & - & 1 & & & & & & & & & & & & & & \\
\hline \multirow{2}{*}{ Turb } & $\mathrm{r}$ & - & 0,92 & 1 & & & & & & & & & & & & & \\
\hline & $\mathrm{d}$ & - & 0,99 & 1 & & & & & & & & & & & & & \\
\hline \multirow{2}{*}{ pH } & $\mathrm{r}$ & - & - & - & 1 & & & & & & & & & & & & \\
\hline & $\mathrm{d}$ & 0,85 & - & - & 1 & & & & & & & & & & & & \\
\hline \multirow{2}{*}{ E.C } & $\mathrm{r}$ & - & - & - & 0,83 & 1 & & & & & & & & & & & \\
\hline & $\mathrm{d}$ & 0,92 & - & - & 0,90 & 1 & & & & & & & & & & & \\
\hline \multirow{2}{*}{ TDS } & $r$ & - & - & - & 0,83 & 1 & 1 & & & & & & & & & & \\
\hline & $\mathrm{d}$ & 0,92 & - & - & 0,90 & 1 & 1 & & & & & & & & & & \\
\hline \multirow{2}{*}{ D.O } & $r$ & - & - & 0,76 & 0,71 & - & - & 1 & & & & & & & & & \\
\hline & $\mathrm{d}$ & - & - & - & 0,73 & 0,73 & 0,73 & 1 & & & & & & & & & \\
\hline \multirow{2}{*}{ Alkali } & $\mathrm{r}$ & - & - & - & 0,75 & 0,95 & 0,95 & - & 1 & & & & & & & & \\
\hline & $\mathrm{d}$ & 0,71 & - & - & - & - & - & - & 1 & & & & & & & & \\
\hline \multirow{2}{*}{$\mathbf{N H}_{3}$} & $\mathrm{r}$ & - & 0,88 & 0,71 & - & - & - & - & - & 1 & & & & & & & \\
\hline & $\mathrm{d}$ & - & - & - & - & - & - & - & - & 1 & & & & & & & \\
\hline \multirow{2}{*}{$\mathbf{N a}$} & $\mathrm{r}$ & - & - & - & 0,83 & 0,85 & 0,85 & 0,71 & 0,90 & - & 1 & & & & & & \\
\hline & $\mathrm{d}$ & - & - & - & - & - & - & 0,77 & - & - & 1 & & & & & & \\
\hline \multirow{2}{*}{$\mathbf{K}$} & $r$ & - & - & - & 0,95 & 0,88 & 0,88 & - & 0,80 & - & 0,76 & 1 & & & & & \\
\hline & $\mathrm{d}$ & 0,73 & - & - & - & 0,71 & 0,71 & - & 0,88 & - & 0,82 & 1 & & & & & \\
\hline \multirow{2}{*}{$\mathrm{SO}_{4}^{2}$} & $\mathrm{r}$ & - & - & - & - & 0,74 & 0,74 & - & 0,76 & - & - & 0,77 & 1 & & & & \\
\hline & $\mathrm{d}$ & 0,80 & - & - & - & - & - & - & 0,80 & - & - & 0,80 & 1 & & & & \\
\hline \multirow{2}{*}{$\mathrm{PO}_{4}{ }^{3-}$} & $\mathrm{r}$ & - & - & - & - & - & - & - & - & - & - & - & - & 1 & & & \\
\hline & $\mathrm{d}$ & - & - & - & 0,70 & - & - & - & - & - & - & - & 1 & 1 & & & \\
\hline \multirow{2}{*}{$\mathrm{NO}_{3}^{-1}$} & $\mathrm{r}$ & - & - & - & - & 0,71 & 0,71 & - & 0,80 & - & 0,73 & - & - & - & 1 & & \\
\hline & $\mathrm{d}$ & - & - & - & - & - & - & - & - & - & - & - & 1 & 0,90 & 1 & & \\
\hline \multirow{2}{*}{$\mathrm{Cl}^{-}$} & $r$ & - & - & 0,75 & 0,85 & 0,75 & 0,75 & 0,86 & 0,83 & - & 0,93 & 0,80 & 0,72 & - & - & 1 & \\
\hline & $\mathrm{d}$ & 0,73 & - & - & - & - & - & - & - & - & - & - & 1 & - & - & 1 & \\
\hline \multirow{2}{*}{$\mathbf{F}^{-}$} & $r$ & 0,91 & - & - & - & - & - & - & 0,70 & - & 0,80 & - & - & - & 0,83 & 0,73 & 1 \\
\hline & $\mathrm{d}$ & 0,90 & - & - & - & - & - & - & 0,70 & - & - & 0,70 & 1 & - & 0,80 & 0,80 & 1 \\
\hline
\end{tabular}

PS: the results are presented about the correlations results about $>-0,70$ *r =raining period; $d=$ dry period. 
Table 4: Spearman Correlation Matrix between the physicochemical parameters, in Stream Jose Gomes waters in the raining and dry periods. The meaningful correlation with $\mathrm{p}<0,05$.

\begin{tabular}{|c|c|c|c|c|c|c|c|c|c|c|c|c|c|c|c|c|c|}
\hline & Time* & Temp & Color & Turb & pH & E.C & TDS & D.O & Alkali & $\mathbf{N H}_{3}$ & $\mathrm{Na}$ & K & $\mathrm{SO}_{4}{ }^{2}$ & $\mathrm{PO}_{4}{ }^{3-}$ & $\mathrm{NO}_{3}^{-}$ & $\mathrm{Cl}^{-}$ & $F^{-}$ \\
\hline \multirow{2}{*}{ Temp } & $\mathrm{r}$ & 1 & & & & & & & & & & & & & & & \\
\hline & $\mathrm{d}$ & 1 & & & & & & & & & & & & & & & \\
\hline \multirow{2}{*}{ Color } & $\mathrm{r}$ & - & 1 & & & & & & & & & & & & & & \\
\hline & d & - & 1 & & & & & & & & & & & & & & \\
\hline \multirow{2}{*}{ Turb } & $\mathrm{r}$ & - & 1 & 1 & & & & & & & & & & & & & \\
\hline & d & - & 1 & 1 & & & & & & & & & & & & & \\
\hline \multirow{2}{*}{ pH } & $\mathrm{r}$ & 0,80 & - & - & 1 & & & & & & & & & & & & \\
\hline & d & - & - & - & 1 & & & & & & & & & & & & \\
\hline \multirow{2}{*}{ E.C } & $\mathrm{r}$ & - & - & - & - & 1 & & & & & & & & & & & \\
\hline & d & - & 0,80 & - & - & 1 & & & & & & & & & & & \\
\hline \multirow{2}{*}{ TDS } & $\mathrm{r}$ & - & - & - & - & 1 & 1 & & & & & & & & & & \\
\hline & d & - & 0,80 & 0,80 & - & 1 & 1 & & & & & & & & & & \\
\hline \multirow{2}{*}{ D.O } & $\mathrm{r}$ & - & - & - & - & - & - & 1 & & & & & & & & & \\
\hline & d & $0-\overline{80}$ & - & - & - & - & - & 1 & 1 & & & & & & & & \\
\hline Alkali & d & - & 0.80 & 0,80 & 0,80 & - & - & $\overline{8} 80$ & $\begin{array}{l}1 \\
1\end{array}$ & & & & & & & & \\
\hline \multirow{2}{*}{$\mathrm{NH}_{3}$} & $\mathrm{r}$ & - & - & 1 & - & - & - & - & - & 1 & & & & & & & \\
\hline & d & - & 0,80 & 0,80 & - & 1 & 1 & - & - & 1 & & & & & & & \\
\hline \multirow{2}{*}{$\mathrm{Na}$} & $\mathrm{r}$ & - & - & - & - & 1 & 1 & - & - & - & 1 & & & & & & \\
\hline & d & - & 0,80 & 0,80 & - & 1 & 1 & - & - & 1 & 1 & & & & & & \\
\hline \multirow{2}{*}{$\mathbf{K}$} & $\mathrm{r}$ & - & - & - & - & 1 & 1 & - & - & - & 1 & 1 & & & & & \\
\hline & d & - & - & - & - & 0,80 & 0,80 & - & - & 0,80 & 0,80 & 1 & & & & & \\
\hline \multirow{2}{*}{$\mathrm{SO}_{4}{ }^{2}$} & $\mathrm{r}$ & - & - & - & 1 & - & 1 & - & - & - & 1 & 1 & 1 & & & & \\
\hline & d & 1 & - & - & - & 1 & 1 & - & - & 1 & 1 & 1 & 1 & & & & \\
\hline \multirow{2}{*}{$\mathrm{PO}_{4}{ }^{3-}$} & $\mathrm{r}$ & - & - & - & - & - & - & - & - & - & - & - & - & 1 & & & \\
\hline & d & 1 & - & - & - & - & - & 1 & 1 & - & - & - & - & 1 & & & \\
\hline \multirow{2}{*}{$\mathrm{NO}_{3}^{-1}$} & $\mathrm{r}$ & - & 0,80 & 0,80 & - & - & - & - & - & 0,80 & - & - & - & - & 1 & & \\
\hline & d & - & - & - & - & - & - & - & - & - & - & - & 1 & - & 1 & & \\
\hline \multirow{2}{*}{$\mathrm{Cl}^{-}$} & $\mathrm{r}$ & - & - & - & - & 0,80 & 0,80 & - & - & - & 0,80 & 0,80 & 0,80 & - & 0,80 & 1 & \\
\hline & $\mathrm{d}$ & - & 0,80 & 0,80 & - & 1 & 1 & - & - & 1 & 1 & 0,80 & 1 & - & - & 1 & \\
\hline \multirow{2}{*}{$\mathbf{F}^{-}$} & $\mathrm{r}$ & - & - & - & 1 & 1 & 1 & - & - & - & 1 & 1 & 1 & - & - & 0,80 & 1 \\
\hline & d & 1 & - & - & - & - & - & - & 1 & - & - & - & - & - & - & - & 1 \\
\hline
\end{tabular}

PS: The correlation results are showed with $>0,70 * \mathrm{r}=$ raining period; $\mathrm{d}=$ dry period.

Among the parameters correlations, the T.D.S and E.C, for being directed proportional shows the same way in Stream Bandeirinha and Josefa Gomes as far as they correlate with the parameters: $\mathrm{HCO}_{3}{ }^{-} \mathrm{NH}_{3} \mathrm{Na} \mathrm{K} \mathrm{SO}{ }_{4}{ }^{2-} \mathrm{NO}_{3}{ }^{-1} \mathrm{Cl}^{-} \mathrm{F}^{-}$. These correlations are stronger in the dry season, due to the concentration of elements in the water. The strong correlations between $\mathrm{NH}_{3}, \mathrm{Na}, \mathrm{K}, \mathrm{SO}_{4}{ }^{2-}, \mathrm{NO}_{3}{ }^{-}$and $\mathrm{Cl}^{-}$in both periods, in both drainages suggest the contributions for domestic effluents.

The parameters of Color and Turbidly show correlation in the raining period for being directed linked to the material quantity in the water, dragged in this period. It is observed that those factors have a different way of reaction in Stream Josefa Gomes with strong correlations with the ions $\mathrm{HCO}_{3}{ }^{-}, \mathrm{NH}_{3}$, $\mathrm{Na}, \mathrm{Cl}^{-}$, in the dry season, indicating the possible contribution in the urban area.

The $\mathrm{pH}$ presents a different behavior between the two drainages in relation with the elements correlations. It is also observed that in Stream Bandeirinha, the pH had some correlations with E.C, T.D.S, D.O, $\mathrm{HCO}_{3}{ }^{-}, \mathrm{Na}, \mathrm{K}, \mathrm{SO}_{4}{ }^{2-}, \mathrm{NO}_{3}{ }^{-}, \mathrm{Cl}^{-}, \mathrm{F}^{-}$, stronger in the raining period indicating the elements concentration in this drainage occur in a soluble form in a soft alkaline water.

The stream Josefa Gomes $\mathrm{pH}$ only relates to the $\mathrm{HCO}_{3}{ }^{-}, \mathrm{SO}_{4}{ }^{2-}$ and $\mathrm{F}^{-}$. This drainage should be considered that the contribution of the elements is higher in two seasons due to urban area. Higher concentrations of the elements may have reduced the correlation of $\mathrm{pH}$ with the other elements in the water. While the stream Bandeirinha the contribution of the elements is smaller and arises from the 
weathering processes of rocks and banks of the drainage result of the geological characteristics of the region.

The $\mathrm{NH}_{3}$ presents strong correlations in Stream Josefa Gomes in the dry period with $\mathrm{Na}, \mathrm{K}, \mathrm{SO}_{4}{ }^{2-}$ $\mathrm{NO}_{3}{ }^{-}, \mathrm{Cl}^{-}$, and being these elements presented in domestic effluents launching. It is also showed a strong correlation in $\mathrm{NH}_{3}$ with the E.C and T.D.S in the dry period $(r=1)$, indicating the concentration of elements in the dry period and the possibility of a strong launching of domestic effluents continuum that is diluted in the raining period and it's showed in the dry period.

The correlations below of the meaning, between the Temperature and the D.O, that occurred in the two drainages, indicate that to the Stream Bandeirinha and also to the Stream Josefa Gomes the morphology of the drainages, there are more influence over the D.O quantity than the average temperature of the region.

The $\mathrm{SO}_{4}{ }^{2-}$ showed the same result in relation between the correlation in both streams having strong correlations with the $\mathrm{Na}, \mathrm{K}, \mathrm{PO}_{4}{ }^{3-}, \mathrm{NO}_{3}{ }^{-}, \mathrm{Cl}^{-}$and $\mathrm{F}^{-}$, evidenced in the dry period, but it comes to different origins. To the Stream Bandeirinha, the $\mathrm{SO}_{4}{ }^{2-}$ comes from manure and is prepared in the rural area soil while the Stream Josefa Gomes comes from domestic effluents.

\section{Sediments}

The granulometric fraction result varied from medium rock fragments $(16-8 \mathrm{~mm})$; then rock fragments $(8-4 \mathrm{~mm})$ thick sand $(1-0,50 \mathrm{~mm})$, average sand $(0,50-0,25 \mathrm{~mm})$, then sand $(0,25-0,12$ $\mathrm{mm}$ ) classified according to the Krumbein scale and adopted procedures by the Geotechnics Laboratory of IFG. In the samples of the granulometric fraction of 0,50 to $0,12 \mathrm{~mm}$, corresponding to the average and thin area, natural components presented in the source of this drainage. The sediments showed in the points of Stream Josefa Gomes show a major concentration of thick sand (1- 0,50 mm) followed by the thin rock fragment $(8-4 \mathrm{~mm})$ and average rock fragment $(16-8 \mathrm{~mm})$. This difference in the results between the drainages comes from the presence of material in the Stream Josefa Gomes and is prevenient from contributions of the rain water system.

The granulometric fractions results were suitable with the geological characteristics of the region represented by the Paranoa Group and Bambui Group with a coverage of detritus-lateritic of the tertiaryquaternary period and recent alluvial in the borders of the water courses, corresponding to clastics sediments deposit (sand, rock fragments and mud) formed by the fluvial system in the course and borders of stream Bandeirinha and Josefa Gomes.

As for the minerology the results are presented in the Table $\mathbf{0 5}$. The points showed at stream Bandeirinha make clear that the predominance of quartz presence with more samples, identified together or isolated with the kaolinite, or more associated with the gibbsite, ilite or muscovite. The quartz is presented in the sediments of the deep underdrainage that comes from the rework of the borders material and sediments dragging transported by the tributaries. 
Table 05: Diffraction results of X-Rays in the samples of stream Bandeirinha and Josefa Gomes

\begin{tabular}{|c|c|c|c|c|c|}
\hline \multicolumn{3}{|c|}{ X-ray diffraction stream Bandeirinha } & \multicolumn{3}{|c|}{ X-ray diffraction stream Josefa Gomes } \\
\hline Points & $\begin{array}{l}\text { Mineral } \\
\text { species }\end{array}$ & Chemical composition & Points & $\begin{array}{l}\text { Mineral } \\
\text { species }\end{array}$ & Chemical composition \\
\hline PB1 & $\begin{array}{c}\text { Quartz } \\
\text { Gibbsite } \\
\text { Kaolinite } \\
\end{array}$ & $\begin{array}{c}\mathrm{SiO}_{2} \\
\mathrm{Al}(\mathrm{OH})_{3} \\
\mathrm{Al}_{2} \mathrm{Si}_{2} \mathrm{O}_{5}(\mathrm{OH})_{4} \\
\end{array}$ & PJ1 & $\begin{array}{l}\text { Quartz } \\
\text { Kaolinite } \\
\text { Gibbsite } \\
\end{array}$ & $\begin{array}{c}\mathrm{SiO}_{2} \\
\mathrm{Al}_{2} \mathrm{Si}_{2} \mathrm{O}_{5}(\mathrm{OH})_{4} \\
\mathrm{Al}(\mathrm{OH})_{3} \\
\end{array}$ \\
\hline PB2 & $\begin{array}{l}\text { Quartz } \\
\text { Kaolinite }\end{array}$ & $\begin{array}{c}\mathrm{SiO}_{2} \\
\mathrm{Al}_{2} \mathrm{Si}_{2} \mathrm{O}_{5}(\mathrm{OH})_{4}\end{array}$ & \multirow{5}{*}{ PJ2 } & $\begin{array}{l}\text { Quartz } \\
\text { Kaolinite }\end{array}$ & $\begin{array}{c}\mathrm{SiO}_{2} \\
\mathrm{Al}_{2} \mathrm{Si}_{2} \mathrm{O}_{5}(\mathrm{OH})_{4}\end{array}$ \\
\hline PB3 & Quartz & $\mathrm{SiO}_{2}$ & & Gibbsite & $\mathrm{Al}(\mathrm{OH})_{3}$ \\
\hline PB4 & Quartz & $\mathrm{SiO}_{2}$ & & Calcite & $\mathrm{CaCO}_{3}$ \\
\hline PB5 & $\begin{array}{l}\text { Quartz } \\
\text { Kaolinite }\end{array}$ & $\begin{array}{c}\mathrm{SiO}_{2} \\
\mathrm{Al}_{2} \mathrm{Si}_{2} \mathrm{O}_{5}(\mathrm{OH})_{4} \\
\end{array}$ & & $\begin{array}{l}\text { Dolomite } \\
\text { Muscovite }\end{array}$ & $\begin{array}{c}\mathrm{CaMg}\left(\mathrm{CO}_{3}\right)_{2} \\
\mathrm{KAl}_{2}\left(\mathrm{Si}_{3} \mathrm{Al}\right) \mathrm{O}_{10}(\mathrm{OH}, \mathrm{F})_{2}\end{array}$ \\
\hline \multirow[b]{2}{*}{ PB6 } & Quartz & $\mathrm{SiO}_{2}$ & & Hematite & $\mathrm{Fe}_{2} \mathrm{O}_{3}$ \\
\hline & $\begin{array}{l}\text { Kaolinite } \\
\text { Microcline }\end{array}$ & $\begin{array}{c}\mathrm{Al}_{2} \mathrm{Si}_{2} \mathrm{O}_{5}(\mathrm{OH})_{4} \\
\mathrm{KAlSi}_{3} \mathrm{O}_{8}\end{array}$ & \multirow{2}{*}{ PJ3 } & $\begin{array}{c}\text { Quartz } \\
\text { Kaolinite }\end{array}$ & $\begin{array}{c}\mathrm{SiO}_{2} \\
\mathrm{Al}_{2} \mathrm{Si}_{2} \mathrm{O}_{5}(\mathrm{OH})_{4}\end{array}$ \\
\hline \multirow{2}{*}{ PB7 } & $\begin{array}{c}\text { Quartz } \\
\text { Orthoclase }\end{array}$ & $\begin{array}{c}\mathrm{SiO}_{2} \\
(\mathrm{~K}, \mathrm{Ba}, \mathrm{Na})\left(\mathrm{Si}_{1} \mathrm{Al}\right)_{4} \mathrm{O}_{2}\end{array}$ & & $\begin{array}{l}\text { Gibbsite } \\
\text { Ilite }\end{array}$ & $\begin{array}{c}\mathrm{Al}(\mathrm{OH})_{3} \\
(\mathrm{~K}, \mathrm{H} 3 \mathrm{O}) \mathrm{Al}_{2} \mathrm{Si}_{3} \mathrm{AlO}_{10}(\mathrm{OH})_{2}\end{array}$ \\
\hline & $\begin{array}{l}\text { Kaolinite } \\
\text { Ilite }\end{array}$ & $\begin{array}{c}\mathrm{Al}_{2} \mathrm{Si}_{2} \mathrm{O}_{5}(\mathrm{OH})_{4} \\
(\mathrm{~K}, \mathrm{H} 3 \mathrm{O}) \mathrm{Al}_{2} \mathrm{Si}_{3} \mathrm{AlO}_{10}(\mathrm{OH})_{2}\end{array}$ & \multirow[t]{2}{*}{ PJ4 } & $\begin{array}{l}\text { Quartz } \\
\text { Kaolinite }\end{array}$ & $\begin{array}{c}\mathrm{SiO}_{2} \\
\mathrm{Al}_{2} \mathrm{Si}_{2} \mathrm{O}_{5}(\mathrm{OH})_{4}\end{array}$ \\
\hline PB8 & $\begin{array}{l}\text { Quartz } \\
\text { Muscovite } \\
\text { Kaolinite }\end{array}$ & $\begin{array}{c}\mathrm{SiO}_{2} \\
\mathrm{KAl}_{2}\left(\mathrm{Si}_{3} \mathrm{Al}\right) \mathrm{O}_{10}(\mathrm{OH}, \mathrm{F})_{2} \\
\mathrm{Al}_{2} \mathrm{Si}_{2} \mathrm{O}_{5}(\mathrm{OH})_{4}\end{array}$ & & Gibbsite & $\mathrm{Al}(\mathrm{OH})_{3}$ \\
\hline
\end{tabular}

More diversity in the minerals are found in the points PB6, PB7 and PB8 points located near the discharge and has the undirected influence of the urban center, besides the natural dragging of sediments that occur during the drainage. It was identified in this points the microcline, orthoclase, ilite and muscovite, mineral species that origin in the argilominerals presented in Bambui Group and where it is sited in the underdrainage of Stream Bandeirinha.

In Stream Josefa Gomes the determination by diffraction of X-Rays shows the predominance of quartz in a large scale, associated with the kaolinite and gibbsite. Nevertheless there is a more diversity of mineral in points $\mathrm{PJ} 2$, originated from materials dragging, by the use of the urban floor, ciliary wood absence, raining water launching and civil construction residues dragging.

There were determined 8 major elements and 8 traces elements in the sediments of Stream Josefa Gomes (PJ) and Bandeirinha (PB), the results are showed in the Table 06. 
Table 06: Major elements and traces in sediments of stream Bandeirinha and Josefa Gomes.

\begin{tabular}{|c|c|c|c|c|c|c|c|c|c|c|c|c|}
\hline \multicolumn{9}{|c|}{ Stream Bandeirinha } & \multicolumn{4}{|c|}{ Stream Josefa Gomes } \\
\hline $\begin{array}{c}\text { Major } \\
\text { elements } \\
(\%)\end{array}$ & PB1 & PB2 & PB3 & PB4 & PB5 & PB6 & PB7 & PB8 & PJ1 & PJ2 & PJ3 & PJ4 \\
\hline $\mathrm{SiO}_{2} \%$ & 87,98 & 84,17 & 78,62 & 78,53 & 68,34 & 78,47 & 76,49 & 71,24 & 49,17 & 54,9 & 65,54 & 69,15 \\
\hline $\mathrm{Al}_{2} \mathrm{O}_{3} \%$ & 4,71 & 0,73 & 0,96 & 1,35 & 6,52 & 5,47 & 6,29 & 6,59 & 27,83 & 6,95 & 13,4 & 11,2 \\
\hline $\mathrm{Fe}_{2} \mathrm{O}_{3} \%$ & 2,04 & 0,32 & 1,08 & 0,52 & 6,75 & 6,23 & 6,04 & 6,25 & 2,24 & 11,87 & 5,09 & 8,61 \\
\hline $\mathrm{CaO} \%$ & 0,43 & 0,32 & 0,35 & 0,37 & 0,67 & 0,65 & 0,43 & 0,52 & 0,57 & 10,48 & 0,88 & 0,6 \\
\hline $\mathrm{MgO} \%$ & 0,15 & 0,05 & 0,06 & 0,04 & 0,21 & 0,25 & 0,48 & 0,1 & 0,31 & 1,99 & 1,08 & 0,28 \\
\hline $\mathrm{TiO}_{2} \%$ & 0,27 & 0,04 & 0,07 & 0,09 & 0,41 & 0,3 & 0,3 & 0,1 & 2,01 & 0,41 & 0,75 & 0,61 \\
\hline $\mathrm{Na}_{2} \mathrm{O} \%$ & 0,63 & 0,66 & 0,74 & 1,48 & 0,62 & 0,67 & 0,66 & 0,32 & 0,66 & 0,83 & 0,7 & 0,67 \\
\hline $\mathrm{K}_{2} \mathrm{O} \%$ & 0,08 & 0,02 & 0,09 & 0,27 & 0,46 & 0,67 & 1,46 & 0,25 & 0,13 & 0,3 & 1,75 & 0,21 \\
\hline PF\%* & 7,15 & 13,77 & 18,83 & 16,91 & 15,1 & 8,32 & 9,12 & 16,93 & 17,51 & 13,97 & 10,22 & 10,93 \\
\hline Total \% & 103,43 & 100,07 & 100,81 & 99,56 & 99,08 & 101,03 & 101,26 & 102,30 & 100,42 & 101,70 & 99,42 & 102,25 \\
\hline $\begin{array}{c}\text { Traces } \\
\text { elements } \\
(\mathrm{mg} / \mathrm{Kg})\end{array}$ & PB1 & PB2 & PB3 & PB4 & PB5 & PB6 & PB7 & PB8 & PJ1 & PJ2 & PJ3 & PJ4 \\
\hline $\mathbf{B a}$ & $<\mathrm{DL}$ & $<\mathrm{DL}$ & $<\mathrm{DL}$ & $<\mathrm{DL}$ & 4,5 & 7,7 & 3,4 & 4,4 & 3,2 & 8,4 & 0,5 & 0,1 \\
\hline $\mathbf{V}$ & 3,1 & $<\mathrm{DL}$ & 0,2 & 0,3 & 7,9 & 6,3 & 4,1 & 3,7 & 23,6 & 14,7 & 10,4 & 14,7 \\
\hline $\mathrm{Cr}$ & $<\mathrm{DL}$ & $<\mathrm{DL}$ & $<\mathrm{DL}$ & $<\mathrm{DL}$ & 1,5 & 2,3 & 0,9 & 1 & 4,7 & 10,2 & 7,4 & 9,7 \\
\hline Mn & $<\mathrm{DL}$ & $<\mathrm{DL}$ & $<\mathrm{DL}$ & $<\mathrm{DL}$ & 21,5 & 33,1 & 14,7 & 21,9 & 0,3 & 21,2 & $<\mathrm{DL}$ & 3,7 \\
\hline $\mathrm{Cu}$ & $<\mathrm{DL}$ & $<\mathrm{DL}$ & $<\mathrm{DL}$ & $<\mathrm{DL}$ & 0,9 & 3 & 0,5 & 0,6 & 3,3 & 2,4 & 1,1 & 0,7 \\
\hline $\mathbf{Z n}$ & 0,7 & $<\mathrm{DL}$ & 2,1 & $<\mathrm{DL}$ & 64,4 & 9,6 & 4,8 & 2,6 & 13,6 & 6,2 & 0,7 & 1,4 \\
\hline $\mathbf{P}$ & 19 & 4,8 & 8,6 & 7,8 & 34,7 & 44,2 & 42,8 & 49,5 & 93,3 & 53,2 & 23,4 & 32,9 \\
\hline $\mathbf{P b}$ & 0,7 & $<\mathrm{DL}$ & 0,1 & 0,5 & 2,8 & 3,1 & 2,2 & 2,5 & 14,6 & 7,1 & 4 & 4,2 \\
\hline
\end{tabular}

*FL - Fire Loss in \% (measured values to $100 \%$ )

$<\mathrm{DL}-$ Detection Limit minor

Among the major elements, the Si and $\mathrm{Al}$, show more concentration in all of the analyzed point's consequence of the geological characteristics of the region. The $\mathrm{Si}$ and $\mathrm{Al}$ come from the kaolinite, quartz and gibbsite. Schaeffer et al (2008), points out that the Brazilian oxisols show clay fraction minerology, composed by kaolinite, gibbsite, goethica and hematite, varying in its proportions in the interpretation of primary minerals degree.

In Stream Bandeirinha makes salient that the element $\mathrm{Na}$, presented a higher value in point PB4 $(1,48)$ in this position for the diffraction of X-Rays it was determined only the quartz. The presence of $\mathrm{Na}$ in the sediments above. In all analysis it was showed points indicating the anthropic contribution. The downstream of the urban center of the city the points PB5 to PB8, shows major concentrations to the elements $\mathrm{Fe}, \mathrm{Ca}, \mathrm{Mg}, \mathrm{Ti}$, a factor that comes from primarily the intemperism of the rocks from Bambui Group, the raising of the flow in the drainage net of Stream Bandeirinha, that favors the decampment of areas and developments of erosives process and exposed floor dragging, conducted by the rain water net from the city. Besides the anthropic contributions from the downstream urban city center.

In Stream Josefa Gomes the point PJ2 had major changing in the elements $\mathrm{Fe}, \mathrm{Ca}, \mathrm{Mg}$ and $\mathrm{Na}$ and also in the other sample points domineer in the X-Rays determination, the quartz, the kaolinite and gibbsite that explains the concentrations of $\mathrm{Si}$ and Al. Nevertheless in PJ2 it was identified calcite, dolomite, muscovite and hematite, giving preference to the existence of erosive process and exposed floor in its border that can contribute to more elements diversification. The point PJ2 also presented 
major proportional distribution of sediments in granulometric fraction, indicating more material dragging, collaborating to the determination of anthropic changing origins.

To trace elements it is necessary to have the variation in the concentrations between the points of Stream Bandeirinha; part of the determined elements show results below the limit of detection between the PB1 to PB4 points. And the traced elements are found in major concentrations in points PB5 to PB8. This factor comes from the natural characteristics of the PB1 to PB4, period according granulometric determinations and mineralogical occurring in these points of quartz sediment $\left(\mathrm{SiO}_{2}\right)$.

In the points PB5 to PB8 it was identified clay sediments fractions. In this period of Stream Bandeirinha it is located a downstream of the urban center of the city and it was determined major concentrations of traces elements giving importance to the $\mathrm{P}, \mathrm{Pb}, \mathrm{Zn}$ and $\mathrm{Cu}$ that are indicators of grazing activities and contribution to raining water launching.

The elements traces concentrations were more evident in points of Stream Josefa Gomes where it was showed clay fraction in every samples points. Elements such as the $\mathrm{V}, \mathrm{Pb}$ and $\mathrm{Cr}$ indicate the direct influence of the anthropic activities having the hydrocarbons derived from the combustible source.

\section{Bioindicators}

In the bioindicators samples done in both drainages, it was identified 64 taxons with a total of 1.236 individuals with 816 and 420 individuals respectively to Stream Bandeirinha and Josefa Gomes.

The season effect marked by the samples in the dry and pluvial period pointed out a space-season pattern. Hoyer and Rash (1996) state that the seasonal influences in the distribution of these organisms in their habitat, because they alter the subtract characteristics of the food availability and refuge. The special pattern found can be related to the substrate type that is fundamental for the microhabitats organisms' refuge. (Hauer and Resh, 1996; Carvalho e Uieda, 2004).

The benthic macroinvertebrates after being identified were classified as its bioindicators function as sensitive communities structures. They vary from organisms proper of clean water, intolerant to pollution, simple of low diversity with organisms capable of living in polluted water. The bioindicators were divided in three major groups: sensitive organisms or intolerant, tolerant organisms and resistance organisms, showed in Table 07. 
Table 07. Taxons classifications concerning to the bioindication and tolerance of environments according to Callisto et al (2004). Stream Bandeirinha (PB) and Josefa Gomes (PJ) raining period (R) dry period (D).

\begin{tabular}{|c|c|c|c|c|c|c|c|c|c|c|c|c|c|c|c|c|c|c|c|c|c|c|c|c|c|}
\hline \multirow{3}{*}{\multicolumn{2}{|c|}{$\begin{array}{c}\text { Bioindicators } \\
\text { Season }\end{array}$}} & \multirow{3}{*}{\multicolumn{2}{|c|}{ PB1 }} & \multicolumn{14}{|c|}{ Stream Bandeirinha } & \multicolumn{8}{|c|}{ Stream Josefa Gomes } \\
\hline & & & & \multicolumn{2}{|c|}{ PB2 } & \multicolumn{2}{|c|}{ PB3 } & \multicolumn{2}{|c|}{ PB4 } & \multicolumn{2}{|c|}{ PB5 } & \multicolumn{2}{|c|}{ PB6 } & \multicolumn{2}{|c|}{ PB7 } & \multicolumn{2}{|c|}{ PB8 } & \multicolumn{2}{|c|}{ PJ1 } & \multicolumn{2}{|c|}{ PJ2 } & \multicolumn{2}{|c|}{ PJ3 } & \multicolumn{2}{|c|}{ PJ4 } \\
\hline & & & & $\mathbf{R}$ & D & $\mathbf{R}$ & D & $\mathbf{R}$ & D & $\mathbf{R}$ & D & $\mathbf{R}$ & D & $\mathbf{R}$ & D & $\mathbf{R}$ & D & $\mathbf{R}$ & D & $\mathbf{R}$ & D & $\mathbf{R}$ & D & $\mathbf{R}$ & D \\
\hline \multirow{4}{*}{ 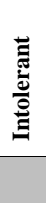 } & Trichoptera & 6 & 21 & 11 & 15 & 0 & 14 & 2 & 17 & 7 & 12 & 4 & 14 & 2 & 8 & 17 & 47 & 1 & 8 & 0 & 0 & 0 & 11 & 0 & 0 \\
\hline & Plecoptera & 2 & 5 & 0 & 0 & 2 & 1 & 0 & 0 & 0 & 0 & 1 & 4 & 0 & 0 & 0 & 0 & 0 & 0 & 0 & 0 & 0 & 0 & 0 & 0 \\
\hline & Ephemeroptera & 2 & 10 & 11 & 21 & 13 & 27 & 1 & 55 & 0 & 3 & 11 & 9 & 5 & 27 & 5 & 13 & 0 & 1 & 0 & 0 & 0 & 1 & 0 & 0 \\
\hline & sum & 10 & 36 & 22 & 36 & 15 & 42 & 3 & 72 & 7 & 15 & 16 & 27 & 7 & 35 & 22 & 60 & 1 & 9 & $\mathbf{0}$ & $\mathbf{0}$ & 0 & 12 & $\mathbf{0}$ & $\mathbf{0}$ \\
\hline \multirow{4}{*}{ 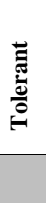 } & Coleoptera & 2 & 12 & 1 & 9 & 3 & 0 & 1 & 10 & 2 & 7 & 9 & 15 & 2 & 0 & 5 & 7 & 0 & 3 & 0 & 0 & 0 & 0 & 0 & 8 \\
\hline & Heteroptera & 0 & 0 & 1 & 3 & 1 & 0 & 0 & 2 & 2 & 3 & 0 & 0 & 0 & 0 & 0 & 0 & 0 & 0 & 1 & 0 & 0 & 1 & 0 & 3 \\
\hline & Odonata & 1 & 5 & 1 & 3 & 1 & 4 & 1 & 4 & 0 & 0 & 0 & 0 & 0 & 1 & 0 & 0 & 1 & 0 & 0 & 3 & 0 & 7 & 0 & 3 \\
\hline & sum & 3 & 17 & 3 & 15 & 5 & 4 & 2 & 16 & 4 & 10 & 9 & 15 & 2 & 1 & 5 & 7 & 1 & 3 & 1 & 3 & 0 & 8 & 0 & 14 \\
\hline \multirow{4}{*}{ 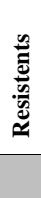 } & Diptera & 18 & 35 & 15 & 14 & 1 & 12 & 6 & 13 & 1 & 7 & 9 & 9 & 5 & 21 & 15 & 28 & 4 & 71 & 16 & 87 & 2 & 38 & 4 & 8 \\
\hline & Annelida & 0 & 1 & 0 & 1 & 0 & 4 & 0 & 0 & 0 & 3 & 0 & 0 & 0 & 5 & 0 & 0 & 0 & 23 & 8 & 35 & 2 & 17 & 4 & 1 \\
\hline & Mollusca & 0 & 1 & 4 & 1 & 0 & 0 & 7 & 3 & 0 & 0 & 0 & 0 & 0 & 1 & 0 & 1 & 0 & 5 & 1 & 8 & 0 & 3 & 2 & 3 \\
\hline & sum & 18 & 37 & 19 & 16 & 1 & 16 & 13 & 16 & 1 & 14 & 9 & 9 & 5 & 27 & 15 & 29 & 4 & 99 & 25 & 130 & 4 & 58 & 10 & 12 \\
\hline
\end{tabular}

The results obtained in the bioindicators evaluations points out the presence of intolerants species in every points of Stream Bandeirinha. The majority number of the species were found in points PB2 and PB8, points in the rainy and dry seasons and PB4 dry period indicating environmental conditions favorable to sensitive species to the environmental changing. The resistance and tolerates species were also found in the rainy and dry seasons in all sampling points, with the most tolerant rates for the points PB1, PB2, PB4 and PB6 in the dry season. The minor richness and diversity were found in point PB8 indicating changing process in Stream Bandeirinha.

The presence of major taxonomic groups of Ephemeroptera, Plecoptera and Trichoptera (EPT) in benthic invertebrate's samples shows places with a best quality of environment. The characteristics with lotics places with flows in the points showed, helps the abundancy and also the richness of major of taxons. The environmental quality in the points of stream Bandeirinha can be verified by the presence in points PB1, PB3, PB6 of Anacroneuria type (Plecoptera) that only lives in places that present a great quality of water. In the points $\mathrm{PB} 2$ and PB3 were registered major quantities of sensitive taxons Leptophlebiidae and PB4 the largest number of Ephemeroptera.

The subtracted type registered in all points, according to the granulometric characterization were sand and gravel favoring the taxons presence more sensitive, such as the Ephemeropthera, Trichoptera and Plecoptera, subtracts formed by gravels and leaves show more richness because they support a major quantity of macroinvertebrates.

In Stream Josefa Gomes in all points predominated the resistant's species. The points PJ3 and PJ4 in the rainy season show only resistant's species of Annelida (Oligochaete) order and Mollusca (Gastropoda) indicating relevant anthropic changing. The non-occupancy space-time of some registered taxons among the 12 points showed (stream Bandeirinha and Josefa Gomes) can be related to the colonization capacity of showed groups, with the influence of the generated disturbance. In the granulometric and biotic relation the heterogeneity of the physical composition of the sediment can be 
influenced in both drainages, but having more influence in Stream Josefa Gomes with a minor number of taxons and individuals settlers.

\section{Methods Integration Pattern}

The application of the integration pattern of analysis methods show the water quality variation in Stream Bandeirinha and Josefa Gomes, indicating the influence on the anthropic processes. The results of this are summarized in Table $\mathbf{0 8}$ and 09.

Table 08: Model results to stream Bandeirinha and Josefa Gomes in raining period

\begin{tabular}{|c|c|c|c|c|c|c|c|c|c|c|c|c|c|}
\hline \multicolumn{14}{|c|}{ MODEL RAINY PERIOD STREAMS BANDEIRINHA AND JOSEFA GOMES } \\
\hline \multirow{3}{*}{ ANSWERS } & \multirow{3}{*}{ Weight } & \multicolumn{12}{|c|}{ Determinations physicochemical } \\
\hline & & \multicolumn{12}{|c|}{ Interpretation of Results 0 - 5} \\
\hline & & PB1 & PB2 & PB3 & PB4 & PB5 & PB6 & PB7 & PB8 & PJ1 & PJ2 & PJ3 & PJ4 \\
\hline $\begin{array}{l}\text { More effective standardization in the } \\
\text { physicochemical parameters in } \\
\text { relation with the others points; }\end{array}$ & 0,5 & 1 & 1 & 1 & 1 & 2 & 2 & 3 & 2 & 3 & 5 & 4 & 4 \\
\hline \multicolumn{2}{|l|}{ Partial score } & 0,5 & 0,5 & 0,5 & 0,5 & 1 & 1 & 1,5 & 1 & $\mathbf{1 , 5}$ & 2,5 & 2 & 2 \\
\hline $\begin{array}{c}\text { The correlation between parameters } \\
\text { indicating the changing of anthropic } \\
\text { origin; }\end{array}$ & 1,5 & 0 & 1 & 1 & 2 & 3 & 3 & 3 & 3 & 3 & 4 & 4 & 4 \\
\hline \multicolumn{2}{|l|}{ Partial score } & $\mathbf{0}$ & 1,5 & 1,5 & 3 & 4,5 & 4,5 & 4,5 & 4,5 & 4,5 & 6 & 6 & 6 \\
\hline $\begin{array}{l}\text { Standardization in the } \\
\text { physicochemical parameters } \\
\text { indicating anthropic activities. }\end{array}$ & 2 & 1 & 1 & 1 & 1 & 2 & 2 & 2 & 2 & 3 & 4 & 4 & 3 \\
\hline \multicolumn{2}{|l|}{ Partial score } & 2 & 2 & 2 & 2 & 4 & 4 & 4 & 4 & 6 & 8 & 8 & 6 \\
\hline \multicolumn{2}{|l|}{ Final Score Physicochemical } & 0,9 & 2,4 & 2,4 & 3,9 & 6,3 & 6,3 & 6,8 & 6,3 & 7,2 & 10 & 9,6 & 9,2 \\
\hline \multicolumn{14}{|c|}{ Studies Sediments } \\
\hline $\begin{array}{l}\text { Composition changing in the natural } \\
\text { granulometric sediments; }\end{array}$ & 0,5 & 0 & 0 & 0 & 0 & 0 & 0 & 0 & 0 & 0 & 2 & 1 & 0 \\
\hline \multicolumn{2}{|l|}{ Partial score } & $\mathbf{0}$ & $\mathbf{0}$ & $\mathbf{0}$ & $\mathbf{0}$ & $\mathbf{0}$ & $\mathbf{0}$ & $\mathbf{0}$ & $\mathbf{0}$ & $\mathbf{0}$ & 1 & $\mathbf{0 , 5}$ & $\mathbf{0}$ \\
\hline $\begin{array}{l}\text { Non-Proper determinations with the } \\
\text { local Geology; }\end{array}$ & 1,5 & 1 & 0 & 1 & 0 & 1 & 1 & 1 & 1 & 1 & 3 & 1 & 1 \\
\hline \multicolumn{2}{|l|}{ Partial score } & 1,5 & $\mathbf{0}$ & 1,5 & $\mathbf{0}$ & 1,5 & 1,5 & 1,5 & 1,5 & 1,5 & 4,5 & $\mathbf{1 , 5}$ & $\mathbf{1 , 5}$ \\
\hline $\begin{array}{l}\text { The presence of major elements and } \\
\text { anthropic origin traces. }\end{array}$ & 2 & 1 & 1 & 1 & 2 & 3 & 3 & 2 & 2 & 3 & 4 & 3 & 2 \\
\hline \multicolumn{2}{|l|}{ Partial score } & 2 & 2 & 2 & 4 & 6 & 6 & 4 & 4 & 6 & 8 & 6 & 4 \\
\hline \multicolumn{2}{|l|}{ Final Score Sediments } & 3,5 & 2 & 3,5 & 4 & 7,5 & 7,5 & 5,5 & 5,5 & 7,5 & 14 & 8 & 5,5 \\
\hline \multicolumn{14}{|c|}{ Bioindicators } \\
\hline $\begin{array}{c}\text { Reduced or absence of intolerant } \\
\text { organisms }\end{array}$ & 0,5 & 0 & 0 & 0 & 3 & 2 & 0 & 2 & 0 & 4 & 5 & 5 & 5 \\
\hline \multicolumn{2}{|l|}{ Partial score } & $\mathbf{0}$ & $\mathbf{0}$ & $\mathbf{0}$ & 1,5 & 1 & $\mathbf{0}$ & 1 & $\mathbf{0}$ & 2 & 2,5 & 2,5 & 2,5 \\
\hline $\begin{array}{l}\text { Reduced or absence of intolerants and } \\
\text { tolerants organisms; }\end{array}$ & 1,5 & 1 & 1 & 1 & 3 & 2 & 0 & 2 & 1 & 4 & 5 & 5 & 5 \\
\hline \multicolumn{2}{|l|}{ Partial score } & 1,5 & 1,5 & 1,5 & 4,5 & 3 & $\mathbf{0}$ & 3 & 1,5 & 6 & 7,5 & 7,5 & 7,5 \\
\hline Predominance resistents organisms. & 2 & 3 & 2 & 1 & 4 & 0 & 1 & 2 & 1 & 5 & 5 & 5 & 5 \\
\hline \multicolumn{2}{|l|}{ Partial score } & 6 & 4 & 2 & 8 & $\mathbf{0}$ & 2 & 4 & 2 & 10 & 10 & 10 & 10 \\
\hline \multicolumn{2}{|l|}{ Final Score Bioindicators } & 3,3 & 2,7 & 2,1 & 8,4 & 4 & 0,6 & 5,2 & 2,1 & 11 & 13 & 13 & 13 \\
\hline \multicolumn{2}{|l|}{ Final Score Model } & 2,6 & 2,4 & 2,7 & 5,4 & 5,9 & 4,8 & 5,8 & 4,6 & 8,6 & 12 & 10 & 9,1 \\
\hline
\end{tabular}

The results of the pattern application in stream Bandeirinha showed that it predominates in the place within the interval $<5$ indicating natural processes to change the water quality. Only the points PB4, PB5, PB7 surpass this value in the raining period, but limiting to $<6$. These points are located in the downstream of the urban center of the city. The Stream Bandeirinha showed best answers in the dry period. Table 09. The Stream Josefa Gomes practically kept its score with a slight improvement in the raining period. 
Table 09: Model results to stream Bandeirinha and Josefa Gomes in the dry period

\begin{tabular}{|c|c|c|c|c|c|c|c|c|c|c|c|c|c|}
\hline \multicolumn{14}{|c|}{ MODEL DRY PERIOD STREAMS BANDEIRINHA AND JOSEFA GOMES } \\
\hline \multicolumn{14}{|c|}{ Determinations physicochemical } \\
\hline \multirow{2}{*}{ ANSWERS } & \multirow{2}{*}{ Weight } & \multicolumn{12}{|c|}{ Interpretation of Results 0 - 5} \\
\hline & & PB1 & PB2 & PB3 & PB4 & PB5 & PB6 & PB7 & PB8 & PJ1 & PJ2 & $\mathbf{P J 3}$ & PJ4 \\
\hline $\begin{array}{l}\text { More effective standardization in the } \\
\text { physicochemical parameters in relation } \\
\text { with the others points; }\end{array}$ & 0,5 & 0 & 2 & 1 & 1 & 2 & 2 & 3 & 2 & 1 & 5 & 3 & 4 \\
\hline \multicolumn{2}{|l|}{ Partial score } & $\mathbf{0}$ & 1 & 0,5 & 0,5 & 1 & 1 & 1,5 & 1 & 0,5 & 2,5 & 1,5 & 2 \\
\hline $\begin{array}{c}\text { The correlation between parameters } \\
\text { indicating the changing of anthropic } \\
\text { origin; }\end{array}$ & 1,5 & 1 & 2 & 2 & 2 & 3 & 3 & 3 & 3 & 3 & 5 & 4 & 4 \\
\hline \multicolumn{2}{|l|}{ Partial score } & 1,5 & 3 & 3 & 3 & 4,5 & 4,5 & 4,5 & 4,5 & 4,5 & $\mathbf{7 , 5}$ & 6 & 6 \\
\hline $\begin{array}{c}\text { Standardization in the physicochemical } \\
\text { parameters indicating anthropic } \\
\text { activities. }\end{array}$ & 2 & 1 & 1 & 1 & 1 & 1 & 2 & 3 & 2 & 3 & 5 & 4 & 4 \\
\hline \multicolumn{2}{|l|}{ Partial score } & 2 & 2 & 2 & 2 & 2 & 4 & 6 & 4 & 6 & 10 & 8 & 8 \\
\hline \multicolumn{2}{|l|}{ Final Score Physicochemical } & 2,1 & 4,6 & 4,1 & 4,1 & 6,1 & 6,7 & $\mathbf{7 , 8}$ & 6,7 & 6,8 & 13 & 9,9 & 10 \\
\hline \multicolumn{14}{|c|}{ Studies Sediments } \\
\hline $\begin{array}{l}\text { Composition changing in the natural } \\
\text { granulometric sediments; }\end{array}$ & 0,5 & 0 & 0 & 0 & 0 & 0 & 0 & 0 & 0 & 0 & 2 & 1 & 0 \\
\hline \multicolumn{2}{|l|}{ Partial score } & & $\mathbf{0}$ & $\mathbf{0}$ & 0 & $\mathbf{0}$ & $\mathbf{0}$ & $\mathbf{0}$ & $\mathbf{0}$ & $\mathbf{0}$ & 1 & 0,5 & $\mathbf{0}$ \\
\hline $\begin{array}{l}\text { Non-Proper determinations with the } \\
\text { local Geology; }\end{array}$ & 1,5 & 1 & 0 & 1 & 0 & 1 & 1 & 1 & 1 & 1 & 3 & 1 & 1 \\
\hline \multicolumn{2}{|l|}{ Partial score } & & 0 & 1,5 & $\mathbf{0}$ & 1,5 & 1,5 & 1,5 & 1,5 & 1,5 & 4,5 & 1,5 & 1,5 \\
\hline $\begin{array}{c}\text { The presence of major elements and } \\
\text { anthropic origin traces. }\end{array}$ & 2 & 1 & 1 & 1 & 2 & 3 & 3 & 2 & 2 & 3 & 4 & 3 & 2 \\
\hline \multicolumn{2}{|l|}{ Partial score } & & 2 & 2 & 4 & 6 & 6 & 4 & 4 & 6 & 8 & 6 & 4 \\
\hline \multicolumn{2}{|l|}{ Final Score Sediments } & 3,5 & 2 & 3,5 & 4 & 7,5 & 7,5 & 5,5 & 5,5 & 7,5 & 14 & 8 & 5,5 \\
\hline \multicolumn{14}{|c|}{ Bioindicators } \\
\hline $\begin{array}{c}\text { Reduced or absence of intolerant } \\
\text { organisms }\end{array}$ & 0,5 & 0 & 0 & 0 & 0 & 0 & 0 & 0 & 0 & 4 & 5 & 4 & 5 \\
\hline \multicolumn{2}{|l|}{ Partial score } & $\mathbf{0}$ & $\mathbf{0}$ & $\mathbf{0}$ & 0 & $\mathbf{0}$ & $\mathbf{0}$ & $\mathbf{0}$ & $\mathbf{0}$ & 2 & 2,5 & 2 & 2,5 \\
\hline $\begin{array}{l}\text { Reduced or absence of intolerants and } \\
\text { tolerants organisms; }\end{array}$ & 1,5 & 0 & 0 & 1 & 0 & 0 & 0 & 2 & 2 & 4 & 4 & 4 & 3 \\
\hline \multicolumn{2}{|l|}{ Partial score } & $\mathbf{0}$ & $\mathbf{0}$ & 1,5 & $\mathbf{0}$ & $\mathbf{0}$ & $\mathbf{0}$ & 3 & 3 & 6 & 6 & 6 & 4,5 \\
\hline Predominance resistents organisms & 2 & 1 & 1 & 1 & 1 & 1 & 0 & 0 & 0 & 5 & 5 & 5 & 4 \\
\hline \multicolumn{2}{|l|}{ Partial score } & 2 & 2 & 2 & 2 & 2 & 0 & $\mathbf{0}$ & $\mathbf{0}$ & 10 & 10 & 10 & 8 \\
\hline \multicolumn{2}{|l|}{ Final Score Bioindicators } & 0,4 & 0,4 & 1,9 & 0,4 & 0,4 & $\mathbf{0}$ & 3 & 3 & 10 & 11 & 10 & 8,6 \\
\hline \multicolumn{2}{|l|}{ Final Score Model } & 2,7 & 2,3 & 3,2 & 2,8 & 4,7 & 4,7 & 5,4 & 5,1 & 8,1 & 12 & 9,3 & 8,2 \\
\hline
\end{tabular}

The results show that Stream Bandeirinha has a good quality in the physicochemical determinations of the water, in the sediment studies, major elements of the water, in the sediment studies, major elements and traces. The results are according to the local geology, besides the major presence of bioindicators species intolerants and tolerants in the sampled points, validating what was observed in the model application, keeping in the interval of $<5$ to $\leq 7,5$ corresponding to the natural/anthropic changing processes.

The application of the model in Stream Josefa Gomes showed changing in the environment, predominating anthropic processes in the dry period and also in the pluvial period keeping the interval of $\geq 7,5 \leq 15$. Besides the fact that the source PJ1 is located in a city park (Park Mata da Bica) the influence of the urban area and the keeping conditions and preservations of the park helps in the quality changing. The point PJ 2 showed a major index of changing by anthropic processes. This point is located in the end of the rectified way between the joining points of the two avenue of the city and receives influences of the raining drainage system and effluents launching.

The predominant interval of the model, in the Stream Josefa Gomes evaluation indicates an altered water flow. It's possible to verify along the stream that there are effluents launchings, deep valley occupation, solid residues launching, and erosive launching processes, silting, among other impacts 
intensified by the usage and occupation processes of the soil in the urban area. In Figure 3 there are presented the interaction graphics between the answers of applied methods in the two drainages.

(a) Bandeirinha Period: rainy

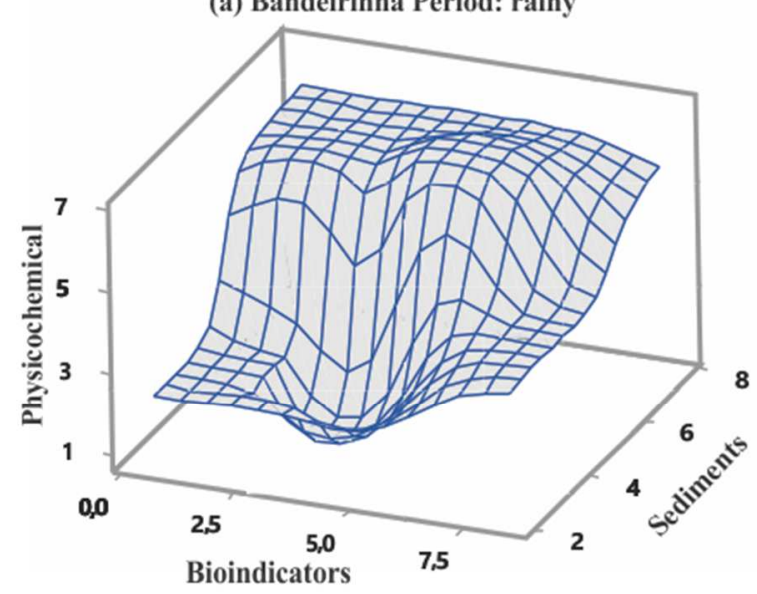

(c) Josefa Gomes Period: rainy

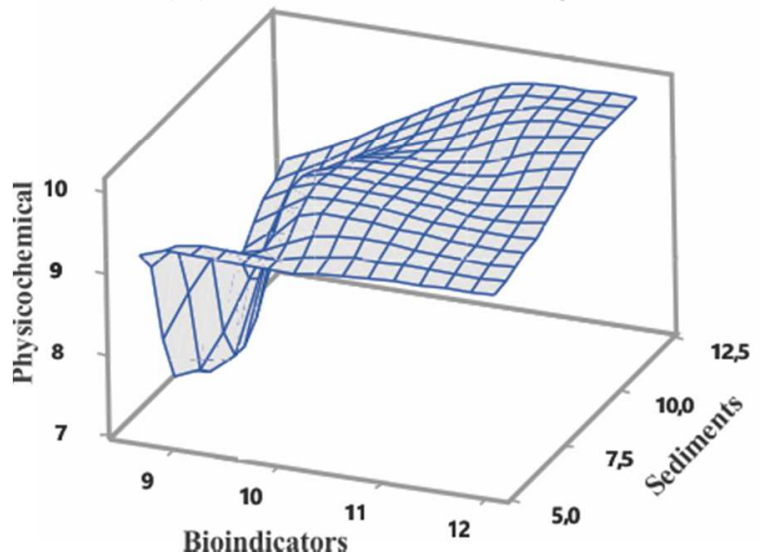

(b) Bandeirinha Period: Dry

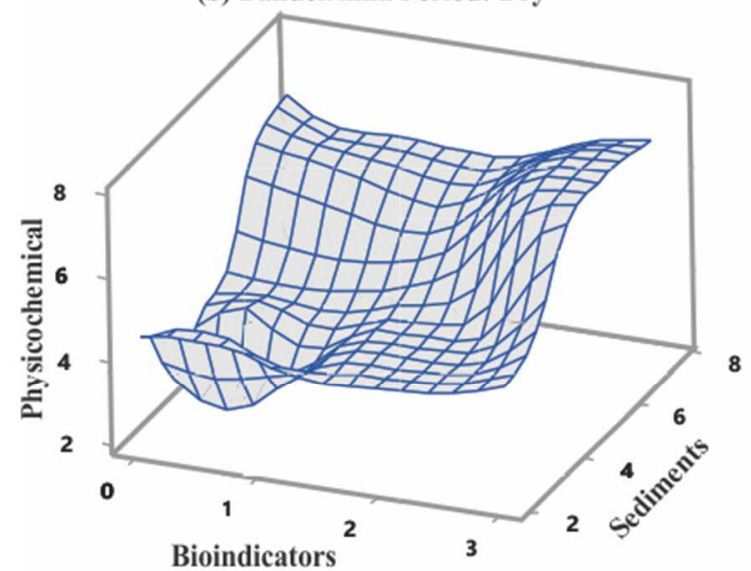

(d) Josefa Gomes Period: Dry

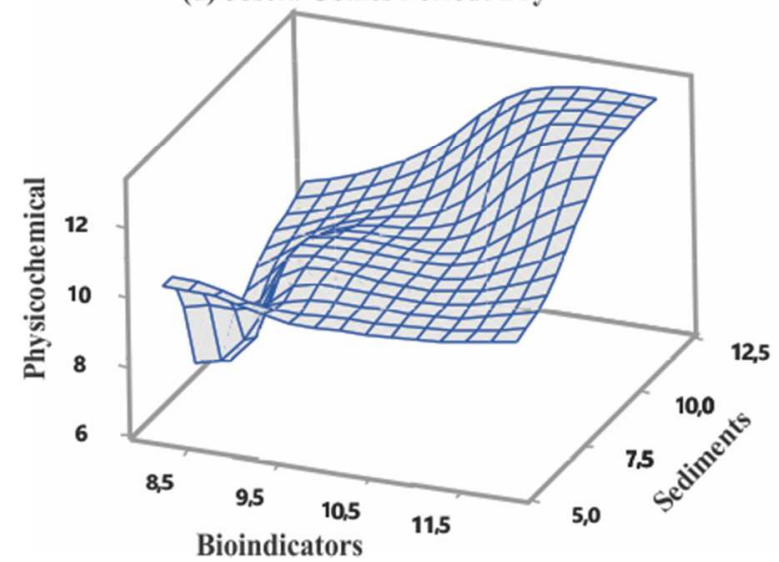

Figure 3: Interaction between 3 methods of analysis using the model, during the rainy season and dry, resulting of Stream Bandeirinha (a, b) and Josefa Gomes (c, d).

The water quality indications pointed out in the applied model to the Stream Bandeirinha are evidenced by the determinations physicochemical and sediments of this drainage, that match to the distribution of the bioindicators species intolerants in all of the showed points. The variation of seasoning in this draining can be realized in Figure 3 (b) corresponding to the dry period, where the intolerants and tolerants bioindicators prevailed, reducing the model score. The Stream Bandeirinha, inserted in the rural area, even with the impacts that came from the agropastoral activities, kept the interval of the natural/anthropic processes changing.

The Stream Josefa Gomes, inserted in the urban place, the generated impacts, changes the water quality in this drainage. All the applied methods indicate anthropic origin changing that were matched and validated the result of the applied model. It was predominantly the presence of species resistant to pollution, with a slight improvement in the rainy season Figure $\mathbf{3}$ (d) but within the anthropic processes changing of quality in accordance with anomalies verified by geochemical analysis. 


\section{CONCLUSIONS}

The water quality of a shallow drainage depends on the interactions that happen between the physics, biotic and anthropic means factors and are linked to a space-time scale and they reflect the dynamics behavior of each environment. The model applied was related to the quality evaluation methods suppressing the uncertainties concerning to the results.

The three methods applied in the model are the simple samples determinations and interpretation. The model was validated by the individual answers of the methods, to the difference between the urban and rural areas in the same region and also because of the wet seasons and dry.

The stream Bandeirinha the PB1 points, $\mathrm{PB} 2, \mathrm{~PB} 3$, kept the value of $<5$ indicating natural processes, while points $\mathrm{PB} 4, \mathrm{~PB} 5, \mathrm{~PB} 6, \mathrm{~PB} 7$ and $\mathrm{PB} 8$ have changes in the rainy season remaining on the value of $<6$ indicating natural/anthropic processes. All stream Josefa Gomes points are situated in the range of $\geq 7,5 \leq 15$, and indicating predominant anthropic processes.

The model provides a simple and effective data integration method based on the responses of each study water quality, resulting in a tool simple to use and application in both urban and rural areas.

The development of the model based on the weight of evidence, answers the need for balance the rigor and discipline, the need for sufficient flexibility to integrate the responses of the methods applied, giving a better final interpretation as water quality.

In both drainages evaluated can be found in varying intensity, anthropic changing coming due to various disagreements of urban planning, socioeconomic and environmental of the city of Formosa, intensified along its history.

The approach integration in the model helps to identify the water quality with a reduced number of samples points generating less costs and analysis time.

The application of the model helps in the identification of associated factors with a variability of the quality and identification of critical areas to the intervention and can be used to subsidize the implement of conservation measures, protections and executions of public policy of environmental management.

\section{ACKNOWLEDMENTS}

The authors are thankful to the professors, technicians and students of Laboratory de Geochemistry of UnB and also from Instituto Federal de Educacão Ciência e Tecnologia Goias - IFG; to the $\mathrm{CNPq}$ and to the CAPES.

\section{REFERENCES}

APHA, AWWA, WPCF. (1999). Standard Methods for the Examination of Water and Wastewater, 20th Ed; Washington, $1496 \mathrm{p}$.

Benedetti. M; Ciaprini. F; Piva. F; Onorati. F; Fattorini. D; Notti. A; Ausili. A; Regoli. F. (2011). A multidisciplinary weight of evidence approach for classifying polluted sediments: Integrating sediment chemistry, bioavailability, biomarkers responses and bioassays. Environment International. 38: 17-28 
Boaventura, G.R.; Moreira, R.C.A. (2003). Referência geoquímica regional para a interpretação das concentrações de elementos químicos nos sedimentos da bacia do lago Paranoá - DF, São Paulo, Brasil. Química Nova, 26(6):812-820.

Boaventura, G. R; Hirson, J. R. (1987). Amostras de Referencia Geoquímica Para Controle de Analise de Rochas. In: Primeiro Congresso Brasileiro de Geoquímica, Anais. Porto Alegre, Brasil. v.1: 321-325.

Borisko. J. P. Kilgour. B. W. Stanfield. W. F. Jones. C. (2007), An Evaluation of Rapid Bioassessment Protocols for Stream Benthic Invertebrates in Southern Ontario, Water Qual. Res. J. Canada, v. 42, no. 3, p. 184-193.

Budkaa. M; Gabrysb. B; Ravagnanc. E. (2010). Robust predictive modelling of water pollution using biomarker data. Water Research.

Callisto, M; Goulart, M.; Medeiros, A.O.; Moreno, P.; Rosa, C.A. (2004). Diversity assessment of benthic macroinvertebrates, yeasts and microbiological indicators along a longitudinal gradient in Serra do Cipó, Brazil. Braz. J. Biol., v. 61, no .2, p, 259-266.

Carmo, M.S.; Boaventura, G. R.; Oliveira, E.C. (2005). Geoquímica das Águas da Bacia do Rio Descoberto, Química Nova, Brasília, v.28, n.4, p. 565-574.

Carvalho, E. M. \& Uieda, V. S. (2004). Colonização por Macroinvertebrados Bentônicos em Substrato Artificial e Natural em um Riacho da Serra de Itatinga, São Paulo, Brasil. Revista Brasileira de Zoologia, v. 21, n. 2, p. 287 293.

Dagnino A, Sforzini S, Dondero F, Fenoglio S, Bona E, Jensen J. (2008). A “Weight-of-Evidence” approach for the integration of environmental "Triad" data to assess ecological risk and biological vulnerability. Integr Environ Assess Manag; 4: 314-26.

ENVIRONMENTAL PROTECTION AGENCY: EPA United States, Rapid Bioassessment Protocols for Use in Streams and Wadeable Rivers: Periphyton, Benthic Macroinvertebrates, and Fish. Disponível em: <http://water.epa.gov/scitech/monitoring/rsl/bioassessment/> Acesso em: 22 de maio de 2013.

Guimarães E.M. (1997). Estudos de proveniência e diagênese, com ênfase na caracterização dos filossilicatos dos grupos Paranoá e Bambuí, na região de Bezerras-Cabeceiras, GO. Tese de doutoramento, Universidade de Brasília.

Hauer, F. R. \& Resh. V. H. (1996). Benthic macroinvertebrates. In: Methods in Stream ecology. San Diego: Academic Press, p. 339-369.

INSTITUTO BRASILEIRO DE GEOGRAFIA E ESTATÍSTICA - IBGE, Censo 2010. Disponível em: <http://www.censo2010.ibge.gov.br/resultados_do_censo2010.php>. Acesso em: 27 ago. 2012.

Le A.H; Tokai A; Nakakubo T. (2014). Applying value of information methods to prioritize elements for water quality management with an example of linear alkylbenzene sulfonate in the Yodo River, Japan. Environment Systems and Decisions, Japan, 34:110-123.

Linkov I, Loney D, Cormier S, Satterstrom FK, Bridges T. (2009). Weight-of-evidence evaluation in environmental assessment: review of qualitative and quantitative approaches. Sci Total Environ; 407:5199-205.

Logan, J; (1965). Interpretação de Análises Químicas da Água. US. Agency for International Development. Recife.

Maia P.D; Gimarães E.D; Moreira R.C.A; Boaventura G.R. (2005). Estudo Mineralógico dos Sedimentos de Fundo do Lago Paranoá DF, São Paulo, Brasil. Brazilian Journal of Geology, 35(4):535-541.

Meier. J.R; Snyder. S; Sigler. V; Altfater. D; Gray. M; Batin. B; Baumann. P; Gordon .D; Wernsing. P; Lazorchak. J. (2013). An Integrated Assessment of Sediment Remediation in a Midwestern U.S. Stream Using Sediment Chemistry, Water Quality, Bioassessment, and Fish Biomarkers. Toxicology and Chemistry, 32(3):653-661.

Mugnai, R.; Nessimian. J.L.; Baptista. D.F. (2010) Manual de Identificação de Macroinvertebrados Aquáticos do Estado do Rio de Janeiro. Rio de Janeiro: Technical Books. 
Mulholland, D.S; Boaventura, G.R; Araújo, D.F. (2012). Geological and anthropogenic influences on sediment metal composition in the upper Paracatu River Basin, Environmental Earth Sciences, 67 (5):1307-1317.

Pimenta, S.M.; Peña. A.P.; Gomes. P.S. (2009). Aplicação de métodos físicos, químicos e biológicos na avaliação da qualidade das águas em áreas de aproveitamento hidroelétrico da bacia do Rio São Tomás, Município de Rio Verde - Goiás. Sociedade \& Natureza, Uberlândia, v, 21 n. 3 p. 393-412.

Poudel D.D, Lee T, Srinivasan R, Abbaspour K, Jeong C.Y. (2013). Assessment of seasonal and spatial variation of surface water quality, identification of factors associated with water quality variability, and the modeling of critical nonpoint source pollution areas in an agricultural watershed. Journal Soil and Water Conservation Society, USA, v.68, n.3, p.155-171.

Reichert. P; Vanrolleghem. P. (2001). Identifiability and uncertainty analysis of the River Water Quality Model No. 1 (RWQM1), Water Science and Technology, 43 (7):329-338.

Ribeiro, L.O.; Uieda, V.S. (2005). Estrutura da comunidade de macroinvertebrados bentônicos de um riacho de serra em Itatinga, São Paulo, Brasil. Revista Brasileira de Zoologia, v. 22, n.3, p. 613-618.

Rodriguez, H.G; Popp, J; Gbur, E; Pennington J. A. (2014). Stakeholder-Guided Collaborative Approach to Improve Water Quality in a Nutrient Surplus Watershed, Journal of Water Resource and Protection, USA, 6:571582.

Schaeffer, C.E.G.R.; Fabris, J.D. \& Ker, J.C. (2008) Minerals in the clay fraction of Brazilian Latosols (Oxisols): a review, Crete, Greece, Clay Miner, 43(1):137-154.

Semenzin E, Critto A, Rutgers M, Marcomini A. (2008). Integration of bioavailability, ecology and ecotoxicology by three lines of evidence into ecological risk indexes for contaminated soil assessment. Sci Total Environ; 389:71-86.

Souza, J.D. (Coord.). 2004. Carta Geológica do Brasil ao Milionésimo: Folha Brasília SD 23. Brasília: CPRM.

Suter GW, Cormier SM. (2011). Why and how to combine evidence in environmental assessments: weighing evidence and building cases. Sci Total Environ; 409:1406-17.

Zhang Z; Chen .Y, Wang .P, Shuai .J, Tao .F, Shi .P. (2014). River discharge, land use change, and surface water quality inthe Xiangjiang River, Hydrological Processes, China, v.28, n.13: 4130-4140. 


\section{MODELO APLICADO NOS PERÍODOS CHUVOSO E SECO DE 2015}

O modelo foi aplicado nos períodos chuvoso e seco 2015 nos 08 pontos do córrego Bandeirinha, e 04 pontos do córrego Josefa Gomes. As coletas ocorreram nos meses de abril e setembro.

Foram realizadas as determinações físico-químicas, e a identificação de bioindicadores. Para complementar o modelo foi utilizado os resultados do estudo de sedimentos realizado em 2013 e apresentado no artigo "Estudo dos Sedimentos de Corrente em Drenagens Inseridas na Área Rural e Área Urbana do Município de Formosa-GO".

\subsection{DETERMINAÇÕES FíSICO-QUÍMICAS}

Foram realizadas em campo as determinações de $\mathrm{pH}$, Temperatura, Condutividade Elétrica e Totais de Sólidos Dissolvidos, utilizando um multiparâmetro portátil (Hach, série Sension 378) e Oxigênio Dissolvido por meio de Oximetro Micropocessado portátil (modelo OMC-900). Nos laboratórios do IFG e Laboratório de Geoquímica da UnB foram determinados Turbidez; Cor; $\mathrm{NH}_{3}$, $\mathrm{K} ; \mathrm{Cl}^{\prime}, \mathrm{NO}_{3}{ }^{-}, \mathrm{PO}_{4}{ }^{3-}$ e $\mathrm{SO}_{4}{ }^{2}$ por técnicas colorimétricas com leitura em espectrofotômetro (Hach modelo DR 2000 e SpectroDirect - Lovibond), os resultados estão apresentados na Tabela 01.

Os parâmetros foram determinados com kits reagentes Lovibond. Para a interpretação dos resultados foi aplicada a correlação de Spearman, que auxiliou na identificação das relações entre os parâmetros físico-químicos, Tabelas 2 e 3.

As metodologias utilizadas na determinação dos parâmetros foram baseadas no Standard Methods for the Examination of Water and Wastewater, edição da American Public Health Association (APHA), American Water Works Association (AWWA) e da Water Pollution Control Federation (WPCF). O controle de qualidade, nas análises laboratoriais, foi realizado por amostra padrão de referência do laboratório e amostra de controle (branco). 
Tabela 01: Parâmetros físico-químicos período chuvoso e seco de 2015, Bandeirinha e Josefa Gomes.

\begin{tabular}{|c|c|c|c|c|c|c|c|c|c|c|c|c|c|c|}
\hline \multicolumn{15}{|c|}{ CÓRREGO BANDEIRINHA - PARÂMETROS (Chuva) } \\
\hline \multirow{2}{*}{ Ponto } & \multirow{2}{*}{$\begin{array}{c}T \\
\text { oc }\end{array}$} & \multirow{2}{*}{$\begin{array}{l}\text { Cor } \\
\text { UH }\end{array}$} & \multirow{2}{*}{$\begin{array}{c}\text { Turb } \\
\text { UT }\end{array}$} & \multirow{2}{*}{ pH } & \multirow{2}{*}{$\begin{array}{c}\text { C.E } \\
\mu \mathrm{s} / \mathrm{cm}\end{array}$} & TSD & O.D & Alcal & $\mathrm{NH}_{3}$ & $\mathrm{~K}$ & $\mathrm{SO}_{4}{ }^{2}$ & $\mathrm{PO}_{4}{ }^{3}$ & $\mathrm{NO}_{3}^{-}$ & $\mathrm{Cl}^{-}$ \\
\hline & & & & & & \multicolumn{9}{|c|}{$\mathbf{m g} / \mathbf{L}$} \\
\hline PB1 & 22,5 & 18 & 3 & 5,90 & 6,2 & 2,6 & 6,5 & 3,4 & $<\mathrm{LD}$ & $<\mathrm{LD}$ & $<\mathrm{LD}$ & $<\mathrm{LD}$ & $<L D$ & $<\mathrm{LD}$ \\
\hline PB2 & 22,4 & 51 & 10 & 6,10 & 17,2 & 8,3 & 7,2 & 6,1 & 0,15 & 0,85 & $<\mathrm{LD}$ & 0,41 & $<L D$ & $<\mathrm{LD}$ \\
\hline PB3 & 23,8 & 80 & 13 & 6,32 & 15,3 & 7,4 & 8,2 & 5,8 & 0,22 & 0,95 & $<\mathrm{LD}$ & 0,25 & 0,55 & $<\mathrm{LD}$ \\
\hline PB4 & 23,0 & 120 & 26 & 6,80 & 31,3 & 16,2 & 7,5 & 7,8 & 0,85 & 0,83 & $<\mathrm{LD}$ & 0,45 & 0,63 & 0,73 \\
\hline PB5 & 24,0 & 170 & 32 & 6,48 & 88,1 & 41,7 & 9,3 & 26,4 & 0,14 & 2,85 & $<\mathrm{LD}$ & 0,21 & 0,65 & 0,61 \\
\hline PB6 & 24,4 & 190 & 35 & 6,62 & 106,4 & 50,5 & 6,8 & 32,2 & 0,18 & 3,10 & 2,12 & 0,22 & 0,82 & 0,73 \\
\hline PB7 & 25,3 & 215 & 68 & 7,10 & 118,9 & 62,3 & 9,1 & 39,2 & 0,31 & 3,12 & 3,51 & $<\mathrm{LD}$ & 0,68 & 1,91 \\
\hline PB8 & 24,8 & 385 & 91 & 7,33 & 142,3 & 71,3 & 8,2 & 51,3 & 0,41 & 2,73 & 3,22 & $<\mathrm{LD}$ & 1,42 & 1,25 \\
\hline \multicolumn{15}{|c|}{ CÓRREGO BANDEIRINHA - PARÂMETROS (Seca) } \\
\hline PB1 & 22,0 & 13 & 4 & 5,70 & 6,1 & 2,8 & 5,9 & 1,8 & 0,20 & $<\mathrm{LD}$ & $<\mathrm{LD}$ & 0,58 & $<\mathrm{LD}$ & $<\mathrm{LD}$ \\
\hline PB2 & 23,0 & 27 & 9 & 6,21 & 25,1 & 12,3 & 6,9 & 7,8 & 0,42 & 1,25 & $<\mathrm{LD}$ & 0,79 & 0,55 & 0,85 \\
\hline PB3 & 23,5 & 48 & 12 & 6,60 & 19,2 & 9,7 & 7,8 & 6,1 & 0,41 & 1,10 & $<\mathrm{LD}$ & 0,72 & 0,62 & 0,93 \\
\hline PB4 & 24,5 & 46 & 14 & 6,73 & 23,2 & 12,1 & 8,2 & 7,2 & 0,93 & 0,91 & $<\mathrm{LD}$ & 0,52 & 0,74 & 1,37 \\
\hline PB5 & 25,0 & 13 & 6 & 7,30 & 168,9 & 82,3 & 8,3 & 43,8 & 0,38 & 3,10 & $<\mathrm{LD}$ & $<\mathrm{LD}$ & 0,75 & 0,58 \\
\hline PB6 & 24,5 & 11 & 8 & 7,80 & 184,8 & 96,5 & 9,1 & 48,9 & 0,43 & 3,87 & $<\mathrm{LD}$ & $<\mathrm{LD}$ & 0,85 & 0,63 \\
\hline PB7 & 23,5 & 17 & 9 & 7,22 & 269,5 & 137,5 & 8,2 & 67,8 & 0,32 & 4,63 & 3,25 & 3,13 & 0,92 & 1,30 \\
\hline PB8 & 25,0 & 19 & 7 & 7,64 & 256,3 & 126,3 & 8,5 & 66,3 & 0,46 & 3,89 & 2,35 & 1,23 & 0,81 & 1,10 \\
\hline \multicolumn{15}{|c|}{ CÓRREGO JOSEFA GOMES - PARÂMETROS (Chuva) } \\
\hline \multirow{2}{*}{ Ponto } & \multirow{2}{*}{$\begin{array}{c}T \\
\text { oC }\end{array}$} & \multirow{2}{*}{$\begin{array}{l}\text { Cor } \\
\text { UH }\end{array}$} & \multirow{2}{*}{$\begin{array}{c}\text { Turb } \\
\text { UT }\end{array}$} & \multirow[b]{2}{*}{ pH } & \multirow{2}{*}{$\begin{array}{c}\text { C.E } \\
\mu \mathrm{s} / \mathrm{cm}\end{array}$} & TSD & O.D & Alcal & $\mathrm{NH}_{3}$ & K & $\mathrm{SO}_{4}{ }^{2}$ & $\mathrm{PO}_{4}{ }^{3}$ & $\mathrm{NO}_{3}^{-}$ & $\mathrm{Cl}^{-}$ \\
\hline & & & & & & \multicolumn{9}{|c|}{$\mathrm{mg} / \mathrm{L}$} \\
\hline PJ1 & 23,5 & 6 & 2 & 6,31 & 45,3 & 22,3 & 7,9 & 12,8 & 0,35 & 0,75 & $<\mathrm{LD}$ & 0,65 & $<L D$ & 0,85 \\
\hline PJ2 & 24,2 & 35 & 12 & 6,52 & 133,2 & 67,9 & 6,1 & 23,7 & 2,85 & 3,12 & 3,32 & 0,52 & 9,37 & 6,82 \\
\hline PJ3 & 25,0 & 32 & 14 & 6,95 & 156,3 & 78,2 & 7,3 & 35,4 & 1,82 & 0,93 & 2,36 & $<\mathrm{LD}$ & 0,95 & 3,57 \\
\hline $\mathrm{rJ4}$ & 24,0 & 41 & 11 & 7,26 & 141,1 & 73,3 & 6,9 & 36,5 & 1,32 & 0,87 & $<\mathrm{LD}$ & 0,35 & 0,75 & 3,31 \\
\hline \multicolumn{15}{|c|}{ CÓRREGO JOSEFA GOMES - PARÂMETROS (Seca) } \\
\hline $\mathbf{P}$ & 23,0 & 38 & 8 & 6,25 & 53,2 & 27,2 & 7,1 & 23,1 & 0,53 & 0,91 & $<\mathrm{LD}$ & 0,85 & $<\mathrm{LD}$ & 1,32 \\
\hline PJ2 & 24,5 & 57 & 11 & 6,15 & 138,6 & 66,1 & 3,4 & 26,7 & 4,20 & 3,24 & 4,35 & 0,31 & 12,52 & 11,31 \\
\hline PJ3 & 25,0 & 48 & 9 & 6,85 & 133,4 & 64,3 & 4,3 & 32,3 & 2,33 & 2,85 & 3,22 & $<\mathrm{LD}$ & 4,23 & 8,75 \\
\hline PJ4 & 24,0 & 35 & 7 & 6,32 & 136,6 & 65,7 & 5,7 & 31,3 & 1,94 & 2,23 & $<\mathrm{LD}$ & $<\mathrm{LD}$ & 2,11 & 6,12 \\
\hline
\end{tabular}

Obs.: Resultados abaixo do Limite de Detecção (<LD); UH = Unidade de Hasen; UT = Unidade de Turbidez.

Tabela 2: Matriz de correlação de Spearman entre parâmetros físico-químicos, nas águas do córrego Bandeirinha, período chuvoso e seco (2015). Apenas correlações com significância $p<0,05$

\begin{tabular}{|c|c|c|c|c|c|c|c|c|c|c|c|c|c|c|c|}
\hline & Época* & Temp & Cor & Turb & $\mathrm{pH}$ & C.E & TSD & O.D & Alcal & $\mathrm{NH}_{3}$ & $\mathrm{SO}_{4}{ }^{2}$ & $\mathrm{PO}_{4}{ }^{3-}$ & $\mathrm{NO}_{3}^{-}$ & $\mathrm{Cl}^{-}$ & K \\
\hline \multirow[t]{2}{*}{ Temp } & $\begin{array}{ll}\mathrm{C} \\
\mathrm{c}\end{array}$ & 1 & & & & & & & & & & & & & \\
\hline & c & 0,92 & 1 & & & & & & & & & & & & \\
\hline Cor & $\mathrm{s}$ & & 1 & & & & & & & & & & & & \\
\hline \multirow[t]{2}{*}{ Turb } & c & 0,92 & 1 & 1 & & & & & & & & & & & \\
\hline & & & $\begin{array}{l}0,75 \\
0 ?\end{array}$ & $\begin{array}{r}1 \\
0.92\end{array}$ & & & & & & & & & & & \\
\hline $\mathrm{pH}$ & s & $\begin{array}{l}0,81 \\
0,83\end{array}$ & 0,92 & 0,92 & 1 & & & & & & & & & & \\
\hline \multirow{2}{*}{ C.E } & c & 0,85 & 0,97 & 0,97 & 0,90 & 1 & & & & & & & & & \\
\hline & $\mathrm{s}$ & & & & 0,76 & 1 & & & & & & & & & \\
\hline TSD & s & 0,85 & 0,97 & 0,91 & 0,90 & 1 & 1 & & & & & & & & \\
\hline \multirow[t]{2}{*}{ O.D } & c & & - & - & & & & 1 & & & & & & & \\
\hline & $\begin{array}{l}s \\
c\end{array}$ & $\begin{array}{l}0,86 \\
085\end{array}$ & 0.97 & $0 \overline{97}$ & $\begin{array}{l}0,99 \\
0,90\end{array}$ & 0,70 & 0,70 & 1 & 1 & & & & & & \\
\hline Alcal & $\mathrm{s}$ & 0,00 & 标 & T ו & 0,76 & 1 & 1 & 0,70 & 1 & & & & & & \\
\hline $\mathbf{N H}_{3}$ & $\begin{array}{l}c \\
s\end{array}$ & - & - & - & 0,81 & - & 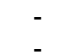 & - & - & 1 & & & & & \\
\hline $\mathrm{SO}_{4}^{2}$ & $\begin{array}{l}c \\
\text { s }\end{array}$ & 0,83 & 0,86 & 0,86 & - & 0,86 & $\begin{array}{l}0,86 \\
076\end{array}$ & - & $\begin{array}{l}0,86 \\
076\end{array}$ & - & 1 & & & & \\
\hline $\mathrm{PO}_{4}{ }^{3-}$ & $\begin{array}{l}c \\
s\end{array}$ & - & - & - & - & - & - & - & - & - & $\overline{-}$ & 1 & & & \\
\hline $\mathrm{NO}_{3}{ }^{-1}$ & $\begin{array}{l}c \\
\text { s }\end{array}$ & 0,89 & 0,97 & 0,97 & $\begin{array}{l}0,87 \\
0,85\end{array}$ & $\begin{array}{l}0,93 \\
0,90\end{array}$ & $\begin{array}{l}0,93 \\
0,90\end{array}$ & $-\overline{81}$ & $\begin{array}{l}0,93 \\
0,90\end{array}$ & - & 0,91 & - & $\begin{array}{l}1 \\
1\end{array}$ & & \\
\hline $\mathrm{Cl}^{-}$ & $\begin{array}{l}c \\
s\end{array}$ & 0,82 & 0,93 & $\begin{array}{l}0,93 \\
0,77\end{array}$ & 0,97 & 0,93 & 0,93 & - & 0,93 & - & 0,75 & - & 0,90 & $\begin{array}{l}1 \\
1\end{array}$ & \\
\hline \multirow[t]{2}{*}{ K } & $\begin{array}{l}c \\
s\end{array}$ & 0,85 & 0,78 & 0,78 & 073 & 0,76 & $\begin{array}{l}0,76 \\
0,97\end{array}$ & - & 0,76 & - & 0,81 & - & 0,74 & - & 1 \\
\hline & $\mathrm{s}$ & & - & & 0,73 & 0,97 & 0,97 & - & 0,97 & - & 0,76 & - & 0,88 & - & 1 \\
\hline
\end{tabular}

São apresentados os resultados das correlações $\geq 0,70{ }^{*} \mathrm{C}=$ época de chuva; $\mathrm{s}=$ época de seca. 
Tabela 3: Matriz de correlação de Spearman entre parâmetros físico-químicos, nas águas do córrego Josefa Gomes, período chuvoso e seco (2015). Apenas correlações com significância $p<0,05$

\begin{tabular}{|c|c|c|c|c|c|c|c|c|c|c|c|c|c|c|c|}
\hline 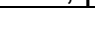 & Época* & Temp & Cor & Turb & $\mathrm{pH}$ & C.E & TSD & O.D & Alcal & $\mathrm{NH}_{3}$ & $\mathrm{SO}_{4}{ }^{2}$ & $\mathrm{PO}_{4}{ }^{3-}$ & $\mathrm{NO}_{3}{ }^{-}$ & $\mathrm{Cl}^{-}$ & $\mathrm{K}$ \\
\hline \multirow{2}{*}{ Temp } & c & 1 & & & & & & & & & & & & & \\
\hline & $s$ & 1 & & & & & & & & & & & & & \\
\hline \multirow{2}{*}{ Cor } & c & - & 1 & & & & & & & & & & & & \\
\hline & $\mathrm{s}$ & - & 1 & & & & & & & & & & & & \\
\hline \multirow{2}{*}{ Turb } & $c$ & 1 & 1 & 1 & & & & & & & & & & & \\
\hline & $s$ & - & 1 & 1 & & & & & & & & & & & \\
\hline \multirow{2}{*}{$\mathrm{pH}$} & c & - & 0,80 & - & 1 & & & & & & & & & & \\
\hline & $s$ & - & - & - & 1 & & & & & & & & & & \\
\hline \multirow{2}{*}{ C.E } & c & - & 0,80 & - & 1 & 1 & & & & & & & & & \\
\hline & $s$ & - & - & - & - & 1 & & & & & & & & & \\
\hline \multirow{2}{*}{ TSD } & c & 0,80 & - & 0,80 & 0,80 & 0,80 & 1 & & & & & & & & \\
\hline & $\mathrm{s}$ & - & - & - & - & 1 & 1 & & & & & & & & \\
\hline \multirow{2}{*}{ O.D } & C & - & - & - & - & - & - & 1 & & & & & & & \\
\hline & $S$ & - & - & - & - & - & - & 1 & & & & & & & \\
\hline Alcal & C & ${ }^{-}$ & 0,80 & - & 1 & 1 & 0,80 & - & 1 & & & & & & \\
\hline \multirow{2}{*}{$\mathbf{N H}_{3}$} & $\begin{array}{l}\mathrm{S} \\
\mathrm{c}\end{array}$ & U,80 & - & - & 0,95 & - & - & - & $\begin{array}{l}1 \\
-\end{array}$ & 1 & & & & & \\
\hline & $\mathrm{s}$ & - & 0,80 & 0,80 & - & 0,80 & 0,80 & - & - & 1 & & & & & \\
\hline \multirow{2}{*}{$\mathrm{SO}_{4}^{2}$} & $c$ & 0,73 & - & 0,73 & - & - & - & - & - & - & 1 & & & & \\
\hline & $s$ & 0,80 & 0,80 & 0,80 & - & 0,80 & 0,80 & - & - & 1 & 1 & & & & \\
\hline \multirow{2}{*}{$\mathrm{PO}_{4}{ }^{3-}$} & C & - & 0,73 & - & - & - & - & - & - & 0,94 & - & 1 & & & \\
\hline & $s$ & - & - & - & - & - & - & - & - & - & - & 1 & & & \\
\hline \multirow{2}{*}{$\mathrm{NO}_{3}{ }^{-1}$} & $c$ & - & - & 0,80 & - & - & - & - & - & 0,80 & 0,94 & - & 1 & & \\
\hline & $\mathrm{s}$ & 0,80 & 0,80 & - & - & 0,80 & 0,80 & - & - & 1 & 1 & - & 1 & & \\
\hline \multirow{2}{*}{$\mathrm{Cl}^{-}$} & c & - & - & 0,80 & - & - & - & - & - & 0,80 & 0,94 & - & 1 & 1 & \\
\hline & $\mathrm{s}$ & 0,80 & 0,80 & 0,80 & - & 0,80 & 0,80 & - & - & 1 & 1 & - & 1 & 1 & \\
\hline \multirow{2}{*}{ K } & C & 0,80 & - & 0,80 & - & - & - & - & - & 0,80 & 0,94 & - & 1 & 1 & 1 \\
\hline & $\mathrm{s}$ & - & 0,80 & - & - & 0,80 & 0,80 & - & - & 1 & 1 & - & 1 & 1 & 1 \\
\hline
\end{tabular}

São apresentados os resultados das correlações $\geq 0,70{ }^{*} \mathrm{C}=$ época de chuva; $\mathrm{s}=$ época de seca.

Os resultados condizem com as determinações dos períodos chuvoso e seco de 2013 e evidencia a diferença entre as duas drenagens e a sazonalidade climática. $O$ córrego Bandeirinha apresenta as maiores alterações a partir do ponto PB5 a PB8. Destaca-se o ponto PB4 com maiores alterações em relação a 2013. Este fato decorre da retomada das obras de construção da barragem de captação de água, próxima ao ponto de coleta. As concentrações de $\mathrm{NH}_{3}, \mathrm{~K}^{-} \mathrm{Cl}^{-}, \mathrm{NO}_{3}{ }^{-}, \mathrm{PO}_{4}{ }^{3-} \mathrm{e}$ $\mathrm{SO}_{4}{ }^{2}$ são maiores a partir do PB5 ao PB8, pontos mais próximos ao núcleo urbano. As correlações entre os parâmetros do córrego Bandeirinha evidencia a influência da concentração dos elementos em meio ácido e alcalino, já que ocorrem correlações mais fortes de $\mathrm{pH}$ e alcalinidade com os demais parâmetros.

Quanto ao córrego Josefa Gomes, destaca-se o ponto PJ2 com as maiores alterações nos parâmetros avaliados. As reduzidas correlações do $\mathrm{pH}$ e alcalinidade em todos os pontos com os demais parâmetros, indicam que a concentração destes são independentes da alcalinidade ou acidez da água. As fortes correlações entre os parâmetros $\mathrm{NH}_{3}, \mathrm{~K} ; \mathrm{Cl}^{-}, \mathrm{NO}_{3}{ }^{-}$, e $\mathrm{SO}_{4}{ }^{2}$ no período chuvoso e seco evidenciam que as concentrações dos elementos, advêm de contribuições de origem antrópica de forma contínua na drenagem.

\subsection{BIOINDICADORES}

Nos pontos de amostragem foi aplicado a identificação de espécies bioindicadoras, utilizando os macroinvertebrados bentônicos coletados com um amostrador tipo Surber, com armação dobrável em aço, tela de nylon $250 \mu$ de abertura na malha, dimensões de abertura de 30 $x 30 \mathrm{~cm}$ e comprimento de $60 \mathrm{~cm}$. 
Foram realizadas 5 réplicas de coleta por ponto. Após coletadas as amostras de bentos foram acondicionados individualmente em frascos plásticos e fixados com álcool $80 \% \mathrm{v} / \mathrm{v}$, para identificação e contagem dos táxons encontrados. A identificação dos táxons foi realizada por meio de Lupa binocular estereoscópica e os indivíduos foram identificados em ordem, família e gênero.

Os bioindicadores foram divididos segundo Callisto et al. (2004) e Pimenta et al. (2009) em três grupos quanto a sua tolerância: organismos sensíveis ou intolerantes (representantes de Trichoptera, Plecoptera, Ephemeroptera), organismos tolerantes (representantes de Coleóptera, Heteroptera, Odonata) e organismos resistentes (Díptera, Oligochaeta). Tabela 4.

Tabela 4: Classificação dos Táxons quanto sua bioindicação a tolerância dos ambientes segundo Callisto et al. (2004). Córregos Bandeirinha e Josefa Gomes, períodos chuvoso e seco 2015.

\begin{tabular}{|c|c|c|c|c|c|c|c|c|c|c|c|c|c|c|c|c|c|c|c|c|c|c|c|c|c|}
\hline \multirow{2}{*}{\multicolumn{2}{|c|}{ Bioindicadores }} & \multicolumn{16}{|c|}{ Córrego Bandeirinha } & \multicolumn{8}{|c|}{ Córrego Josefa Gomes } \\
\hline & & \multicolumn{2}{|c|}{ PB1 } & \multicolumn{2}{|c|}{ PB2 } & \multicolumn{2}{|c|}{ PB3 } & \multicolumn{2}{|c|}{ PB4 } & \multicolumn{2}{|c|}{ PB5 } & \multicolumn{2}{|c|}{ PB6 } & \multicolumn{2}{|c|}{ PB7 } & \multicolumn{2}{|c|}{ PB8 } & \multicolumn{2}{|c|}{ PJ1 } & \multicolumn{2}{|c|}{ PJ2 } & \multicolumn{2}{|c|}{ PJ3 } & \multicolumn{2}{|c|}{ PJ4 } \\
\hline & Período & C & $\mathbf{S}$ & $\mathbf{C}$ & $\mathbf{S}$ & $\mathbf{C}$ & $\mathbf{S}$ & C & $\mathbf{S}$ & $\mathbf{C}$ & $\mathbf{S}$ & $\mathbf{C}$ & $\mathbf{S}$ & $\mathrm{C}$ & $\mathbf{S}$ & $\mathbf{C}$ & $\mathbf{S}$ & C & $\mathbf{S}$ & C & $\mathbf{S}$ & C & $\mathbf{S}$ & C & $\mathbf{S}$ \\
\hline \multirow{4}{*}{ 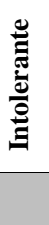 } & Trichoptera & 2 & 25 & 6 & 21 & 2 & 20 & 1 & 5 & 10 & 22 & 5 & 20 & 5 & 15 & 11 & 43 & 3 & 6 & 0 & 0 & 0 & 0 & 0 & 0 \\
\hline & Plecoptera & 2 & 3 & 1 & 0 & 0 & 3 & 0 & 0 & 0 & 0 & 4 & 6 & 4 & 0 & 0 & 0 & 0 & 0 & 0 & 0 & 0 & 0 & 0 & 0 \\
\hline & Ephemeroptera & 3 & 10 & 8 & 25 & 15 & 26 & 1 & 22 & 0 & 1 & 7 & 20 & 7 & 29 & 3 & 8 & 0 & 0 & 0 & 0 & 0 & 0 & 0 & 0 \\
\hline & Somatória & 7 & 38 & 15 & 46 & 17 & 49 & 1 & 27 & 10 & 23 & 16 & 46 & 8 & 44 & 14 & 51 & 3 & 6 & $\mathbf{0}$ & 0 & $\mathbf{0}$ & 0 & 0 & $\mathbf{0}$ \\
\hline \multirow{4}{*}{ 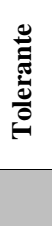 } & Coleóptera & 0 & 12 & 1 & 7 & 2 & 0 & 1 & 16 & 1 & 4 & 7 & 19 & 3 & 0 & 4 & 8 & 0 & 6 & 0 & 0 & 0 & 0 & 0 & 6 \\
\hline & Heteroptera & 1 & 0 & 1 & 2 & 3 & 0 & 2 & 2 & 1 & 6 & 0 & 0 & 0 & 0 & 0 & 0 & 0 & 0 & 0 & 0 & 0 & 0 & 0 & 5 \\
\hline & Odonata & 0 & 9 & 3 & 3 & 2 & 2 & 0 & 3 & 0 & 0 & 0 & 0 & 0 & 0 & 0 & 0 & 2 & 0 & 0 & 5 & 0 & 11 & 0 & 1 \\
\hline & Soma & 1 & 21 & 5 & 12 & 7 & 2 & 3 & 21 & 2 & 10 & 7 & 19 & 3 & $\mathbf{0}$ & 4 & 8 & 2 & 6 & 0 & 5 & $\mathbf{0}$ & 11 & 0 & 12 \\
\hline \multirow{4}{*}{ 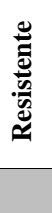 } & Díptera & 14 & 31 & 9 & 15 & 6 & 17 & 4 & 14 & 2 & 18 & 8 & 12 & 4 & 22 & 10 & 34 & 2 & 79 & 11 & 96 & 1 & 47 & 3 & 14 \\
\hline & Anellida & 0 & 0 & 0 & 2 & 0 & 6 & 1 & 0 & 0 & 0 & 0 & 0 & 0 & 8 & 0 & 0 & 0 & 28 & 10 & 36 & 3 & 23 & 6 & 4 \\
\hline & Mollusca & 0 & 3 & 5 & 2 & 0 & 0 & 4 & 6 & 0 & 2 & 0 & 0 & 0 & 2 & 0 & 2 & 0 & 3 & 2 & 12 & 0 & 4 & 2 & 6 \\
\hline & Somatória & 14 & 34 & 14 & 19 & 6 & 23 & 9 & 20 & 2 & 20 & 8 & 12 & $\overrightarrow{7}$ & 32 & 10 & 36 & 2 & 110 & 23 & 144 & 4 & 74 & 11 & 24 \\
\hline
\end{tabular}

$\mathrm{Na}$ amostragem dos bioindicadores realizada durante o período chuvoso e seco de 2015 , em ambas as drenagens, foram identificados 58 táxons com um total de 1.421 indivíduos, sendo 922 e 499 respectivamente para o córrego Bandeirinha e Josefa Gomes. No período seco assim como em 2013 foram amostradas três vezes mais indivíduos $(\mathrm{N}=1.084)$ que na estação chuvosa $(\mathrm{N}=337)$.

Em todos os pontos do córrego Bandeirinha foram identificados táxons intolerantes. O maior número de organismos identificados no período chuvoso (34) foi no ponto PB2, indicando melhor qualidade da água. No período seco destacou-se o PB8 com o maior número de organismos (95). Os pontos PB8 e PB3, apresentam as melhores condições ambientais para táxons intolerantes, com os maiores números de organismos nos períodos seco e chuvoso. Foram identificados em todos os pontos do Bandeirinha táxons tolerantes e resistentes, indicando uma boa diversidade nesta drenagem.

No córrego Josefa Gomes predominou os táxons resistentes e tolerantes, destacando a ausência no ponto PJ2, PJ3 e PJ4 durante os períodos chuvoso e seco, as ordens Ephemeroptera, Plecoptera e Trichoptera (EPT). O ponto PJ2 apresentou o maior número de organismos resistentes ( $\mathrm{N}=23$, período chuvoso; $\mathrm{N}=144$, período seco). 
A partir do ponto PJ2 à PJ4 destaca-se a ausência das ordens Coleóptera, Heteroptera e Odonata no período chuvoso. No ponto PJ2 predominou a presença de táxons resistentes, dos filos Anellida (classe: Oligochaeta); Mollusca (classe: Gastropoda) e Díptera, evidenciando as alterações antrópicas.

\subsection{MODELO DE AVALIAÇÃO}

A interpretação dos resultados das determinações físico-químicas, e a identificação de bioindicadores dos períodos chuvoso e seco de 2015, forneceram as linhas de evidências utilizadas no modelo. Para completar o modelo, foram utilizados os resultados das determinações de sedimentos realizadas no ano 2013. A classificação final das condições do ponto é representada pelo intervalo. Figura 1.

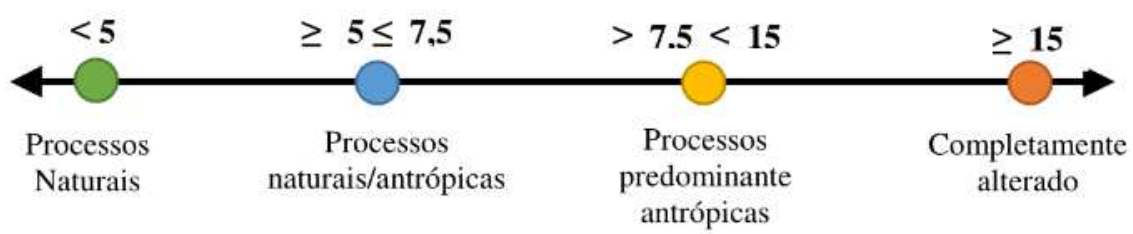

Figura 1. Intervalo para classificação final, integrando os métodos de análise.

A aplicação do modelo de integração dos métodos de análise, demonstra a variação da qualidade da água nos córregos Bandeirinha e Josefa Gomes, indicando a influência dos processos antrópicos. Os resultados da aplicação do modelo estão sintetizados nos Quadros 4 e 5.

Quadro 4: Resultados do modelo para os córregos Bandeirinha e Josefa Gomes no período chuvoso (2015)

\begin{tabular}{|c|c|c|c|c|c|c|c|c|c|c|c|c|c|}
\hline \multirow{2}{*}{\multicolumn{14}{|c|}{$\begin{array}{r}\text { MODELO PERIODO CHUVOSO CÓRREGOS BANDEIRIN } \\
\text { Determinacões Físico-químicas }\end{array}$}} \\
\hline & & & & & & & & & & & & & \\
\hline & \multirow{2}{*}{ Peso } & \multicolumn{12}{|c|}{ Interpretação dos Resultados 0 a 5} \\
\hline RESPOSTAS & & PB1 & PB2 & PB3 & PB4 & PB5 & PB6 & PB7 & PB8 & PJ1 & PJ2 & PJ3 & PJ4 \\
\hline $\begin{array}{l}\text { Maiores aferições nos parâmetros físico- } \\
\text { químicos em relação aos demais pontos. }\end{array}$ & 0,5 & 0 & 1 & 1 & 2 & 2 & 3 & 2 & 2 & 1 & 5 & 4 & 4 \\
\hline \multicolumn{2}{|l|}{ Pontuação Parcial } & $\mathbf{0}$ & 0,5 & 0,5 & 1 & 1 & 1,5 & 1 & 1 & 0,5 & 2,5 & 2 & 2 \\
\hline $\begin{array}{l}\text { Correlação entre parâmetros indicativos de } \\
\text { alterações de origem antrópica }\end{array}$ & 1,5 & 0 & 1 & 1 & 2 & 3 & 3 & 3 & 3 & 3 & 4 & 4 & 4 \\
\hline \multicolumn{2}{|l|}{ Pontuação Parcial } & 0 & 1,5 & 1,5 & 3 & 4,5 & 4,5 & 4,5 & 4,5 & 4,5 & 6 & 6 & 6 \\
\hline $\begin{array}{l}\text { Aferições nos parâmetros físico-químicos } \\
\text { indicativos de atividades antrópicas }\end{array}$ & 2 & 0 & 1 & 1 & 2 & 2 & 3 & 2 & 2 & 4 & 5 & 5 & 4 \\
\hline \multicolumn{2}{|l|}{ Pontuação Parcial } & 0 & 2 & 2 & 4 & 4 & 6 & 4 & 4 & 8 & 10 & 10 & 8 \\
\hline \multicolumn{2}{|l|}{ Pontuação Final Físico-químicos } & 0 & 2,4 & 2,4 & 4,8 & 6,3 & 7,2 & 6,3 & 6,3 & 6,6 & 11 & 10 & 9,6 \\
\hline \multicolumn{14}{|c|}{ Estudo dos Sedimentos } \\
\hline $\begin{array}{c}\text { Alteração na composição granulométrica } \\
\text { natural dos sedimentos }\end{array}$ & 0,5 & 0 & 0 & 0 & 0 & 0 & 0 & 0 & 0 & 0 & 2 & 1 & 0 \\
\hline \multicolumn{2}{|l|}{ Pontuação Parcial } & 0 & 0 & 0 & 0 & 0 & 0 & 0 & 0 & 0 & 1 & 0,5 & 0 \\
\hline $\begin{array}{l}\text { Determinações não condizentes com a } \\
\text { Geologia local }\end{array}$ & 1,5 & 1 & 0 & 1 & 0 & 1 & 1 & 1 & 1 & 1 & 3 & 1 & 1 \\
\hline \multicolumn{2}{|l|}{ Pontuação Parcial } & 1,5 & 0 & 1,5 & 0 & 1,5 & 1,5 & 1,5 & 1,5 & 1,5 & 4,5 & 1,5 & 1,5 \\
\hline $\begin{array}{c}\text { Indicativos da presença de elementos maiores } \\
\text { e traços de origem antrópica }\end{array}$ & 2 & 1 & 1 & 1 & 2 & 3 & 3 & 2 & 2 & 3 & 4 & 3 & 2 \\
\hline \multicolumn{2}{|l|}{ Pontuação Parcial } & 2 & 2 & 2 & 4 & 6 & 6 & 4 & 4 & 6 & 8 & 6 & 4 \\
\hline Pontuação Final Sedimentos & & 3,5 & 2 & 3,5 & 4 & 7,5 & 7,5 & 5,5 & 5,5 & 7,5 & 14 & 8 & 5,5 \\
\hline \multicolumn{14}{|c|}{ Bioindicadores } \\
\hline $\begin{array}{l}\text { Reduzidos ou Ausência de Organismos } \\
\text { Intolerantes }\end{array}$ & 0,5 & 1 & 0 & 0 & 4 & 1 & 0 & 1 & 0 & 4 & 5 & 5 & 5 \\
\hline \multicolumn{2}{|l|}{ Pontuação Parcial } & 0,5 & 0 & 0 & 2 & 0,5 & 0 & 0,5 & 0 & 2 & 2,5 & 2,5 & 2,5 \\
\hline $\begin{array}{l}\text { Reduzidos ou Ausência de Organismos } \\
\text { Intolerantes e Tolerantes }\end{array}$ & 1,5 & 3 & 1 & 1 & 4 & 1 & 0 & 3 & 2 & 4 & 5 & 5 & 4 \\
\hline \multicolumn{2}{|l|}{ Pontuação Parcial } & 4,5 & 1,5 & 1,5 & 6 & 1,5 & 0 & 4,5 & 3 & 6 & 7,5 & 7,5 & 6 \\
\hline Predominância de Organismos Resistentes & 2 & 3 & 1 & 0 & 4 & 2 & 3 & 1 & 2 & 1 & 5 & 5 & 5 \\
\hline \multicolumn{2}{|l|}{ Pontuação Parcial } & 6 & 2 & $\begin{array}{ll}0 \\
\end{array}$ & 8 & 4 & 6 & 2 & 4 & 2 & 10 & 10 & 10 \\
\hline Pontua & & 6,8 & 2,1 & 1,5 & 10 & 3,2 & 1,8 & 5,6 & 4,2 & 8,6 & 13 & 13 & 12 \\
\hline Pontuação Final Modelo & & 3,4 & 2,2 & 2,5 & 6,4 & 5,7 & 5,5 & 5,8 & 5,3 & 7,6 & 12 & 10 & 8,9 \\
\hline
\end{tabular}


Quadro 5: Resultados do modelo para os córregos Bandeirinha e Josefa Gomes no período seco (2015).

\begin{tabular}{|c|c|c|c|c|c|c|c|c|c|c|c|c|c|}
\hline \multicolumn{14}{|c|}{ MODELO PERÍODO SECO CÓRREGOS BANDEIRINHA E JOSEFA GOMES } \\
\hline \multicolumn{14}{|c|}{ Determinações Físico-químicas } \\
\hline & \multirow{2}{*}{ Peso } & \multicolumn{12}{|c|}{ Interpretação dos Resultados 0 a 5} \\
\hline RESPOSTAS & & PB1 & PB2 & PB3 & PB4 & PB5 & PB6 & PB7 & PB8 & PJ1 & PJ2 & PJ3 & PJ4 \\
\hline $\begin{array}{l}\text { Maiores aferições nos parâmetros físico- } \\
\text { químicos em relação aos demais pontos. }\end{array}$ & 0,5 & 0 & 1 & 1 & 2 & 2 & 3 & 2 & 3 & 1 & 5 & 4 & 4 \\
\hline \multicolumn{2}{|l|}{ Pontuação Parcial } & 0 & 0,5 & 0,5 & 1 & 1 & 1,5 & 1 & 1,5 & 0,5 & 2,5 & 2 & 2 \\
\hline $\begin{array}{c}\text { Correlação entre parâmetros indicativos de } \\
\text { alterações de origem antrópica }\end{array}$ & 1,5 & 0 & 1 & 1 & 3 & 2 & 2 & 3 & 3 & 4 & 5 & 5 & 5 \\
\hline \multicolumn{2}{|l|}{ Pontuação Parcial } & 0 & 1,5 & 1,5 & 4,5 & 3 & 3 & 4,5 & 4,5 & 6 & 7,5 & 7,5 & 7,5 \\
\hline $\begin{array}{l}\text { Aferições nos parâmetros físico-químicos } \\
\text { indicativos de atividades antrópicas }\end{array}$ & 2 & 0 & 1 & 1 & 2 & 1 & 1 & 2 & 3 & 4 & 5 & 5 & 4 \\
\hline \multicolumn{2}{|l|}{ Pontuação Parcial } & 0 & 2 & 2 & 4 & 2 & 2 & 4 & 6 & 8 & 10 & 10 & 8 \\
\hline \multicolumn{2}{|l|}{ Pontuação Final Físico-químicos } & 0 & 2,6 & 2,6 & 6,7 & 4,6 & 5,1 & 6,7 & 7,8 & 8,9 & 13 & 13 & 12 \\
\hline \multicolumn{14}{|c|}{ Estudo dos Sedimentos } \\
\hline $\begin{array}{c}\text { Alteração na composição granulométrica } \\
\text { natural dos sedimentos }\end{array}$ & 0,5 & 0 & 0 & 0 & 0 & 0 & 0 & 0 & 0 & 0 & 2 & 1 & 0 \\
\hline \multicolumn{2}{|l|}{ Pontuação Parcial } & 0 & 0 & 0 & 0 & 0 & 0 & 0 & 0 & 0 & 1 & 0,5 & 0 \\
\hline $\begin{array}{c}\text { Determinações não condizentes com a } \\
\text { Geologia local }\end{array}$ & 1,5 & 1 & 0 & 1 & 0 & 1 & 1 & 1 & 1 & 1 & 3 & 1 & 1 \\
\hline \multicolumn{2}{|l|}{ Pontuação Parcial } & 1,5 & 0 & 1,5 & 0 & 1,5 & 1,5 & 1,5 & 1,5 & 1,5 & 4,5 & 1,5 & 1,5 \\
\hline $\begin{array}{l}\text { Indicativos da presença de elementos } \\
\text { maiores e traços de origem antrópica }\end{array}$ & 2 & 1 & 1 & 1 & 2 & 3 & 3 & 2 & 2 & 3 & 4 & 3 & 2 \\
\hline \multicolumn{2}{|l|}{ Pontuação Parcial } & 2 & 2 & 2 & 4 & 6 & 6 & 4 & 4 & 6 & 8 & 6 & 4 \\
\hline Pontuação Final Sedimentos & & 3,5 & 2 & 3,5 & 4 & 7,5 & 7,5 & 5,5 & 5,5 & 7,5 & 14 & 8 & 5,5 \\
\hline \multicolumn{14}{|c|}{ Bioindicadores } \\
\hline $\begin{array}{c}\text { Reduzidos ou Ausência de Organismos } \\
\text { Intolerantes }\end{array}$ & 0,5 & 0 & 0 & 0 & 0 & 0 & 0 & 0 & 0 & 1 & 5 & 1 & 5 \\
\hline \multicolumn{2}{|l|}{ Pontuação Parcial } & 0 & 0 & 0 & 0 & 0 & 0 & 0 & 0 & 0,5 & 2,5 & 0,5 & 2,5 \\
\hline $\begin{array}{l}\text { Reduzidos ou Ausência de Organismos } \\
\text { Intolerantes e Tolerantes }\end{array}$ & 1,5 & 0 & 0 & 2 & 0 & 0 & 0 & 2 & 2 & 4 & 4 & 4 & 4 \\
\hline \multicolumn{2}{|l|}{ Pontuação Parcial } & 0 & 0 & 3 & 0 & 0 & 0 & 3 & 3 & 6 & 6 & 6 & 6 \\
\hline Predominância de Organismos Resistentes & 2 & 0 & 0 & 0 & 1 & 1 & 0 & 1 & 0 & 5 & 5 & 5 & 5 \\
\hline \multicolumn{2}{|l|}{ Pontuação Parcial } & 0 & 0 & 0 & 2 & 2 & 0 & 2 & 0 & 10 & 10 & 10 & 10 \\
\hline Pontuação Final Bioindicadores & & 0 & 0 & 3 & 0,4 & 0,4 & 0 & 3,4 & 3 & 8,5 & 11 & 8,5 & 11 \\
\hline Pontuação Final Modelo & & 1,2 & 1,5 & 3 & 3,7 & 4,2 & 4,2 & 5,2 & 5,4 & 8,3 & 12 & 9,7 & 9,3 \\
\hline
\end{tabular}

$\mathrm{Na}$ aplicação do modelo para o córrego Bandeirinha durante o período chuvoso e seco de 2015, predominou nos pontos PB1, PB2, PB3, o intervalo < 5 indicando processos naturais para as alterações na qualidade da água. Os pontos PB4, PB5, PB6, PB7 e PB8 apresentaram alteração, ultrapassando este valor no período chuvoso, contudo limitando a $<6$ indicando processos naturais/antrópicos. Os pontos PB5 e PB6 estão localizados a jusante do núcleo urbano do município e no PB4 existe alterações decorrentes das obras de implantação da barragem de captação de água.

No córrego Josefa Gomes o ponto PJ2 apresentou os maiores valores nas pontuações parciais para físico-químico, sedimentos e biondicadores, consequentemente a maior pontuação final do modelo durante os períodos chuvoso e seco (12). Todos os pontos desta drenagem situamse no intervalo de $\geq 7,5 \leq 15$, indicando processos predominante antrópicos.

Assim como em 2013 o ponto PJ2 apresenta as maiores alterações. Neste ponto pode ser percebido odor característico de efluente doméstico, presença de resíduos sólidos flutuantes e nas margens, além de processos erosivos. O córrego Josefa Gomes está completamente inserido em ambiente urbano, o que justifica o valor determinado no intervalo pelo modelo aplicado.

Nos períodos chuvoso e seco de 2013 e 2015, em que o modelo foi aplicado, no córrego Bandeirinha, o período chuvoso apresentou as maiores alterações na qualidade, apontando que a 
maior influência na pontuação final do modelo de qualidade da água, decorre da menor diversidade e número de táxons de organismos intolerantes e resistentes, que ocorre durante este período. No período seco mesmo com a concentração dos parâmetros físico-químicos, a maior diversidade e número de táxons dos organismos intolerantes e resistentes tem maior influência na qualidade desta drenagem.

No córrego Josefa Gomes tanto no período seco quanto chuvoso, os pontos permaneceram no intervalo de $\geq 7,5 \leq 15$, assinalando alterações de origem antrópica. A identificação dos bioindicadores aponta predominância de organismos tolerantes e resistentes em ambos períodos, com destaque para maiores números de táxons de organismos resistentes no período seco. $\mathrm{Na}$ Figura 21, estão apresentados os gráficos de interação entre as respostas dos métodos aplicados nas duas drenagens.

(a) Bandeirinha Período: Chuvoso

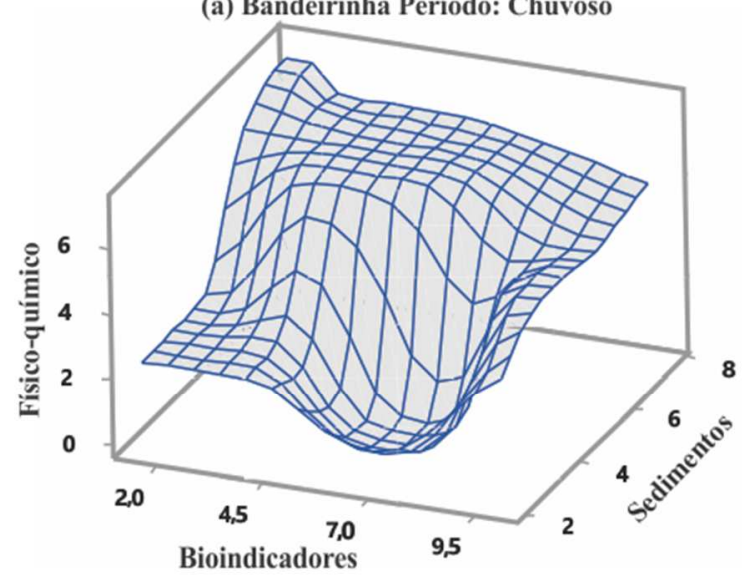

(c) Josefa Gomes Período: Chuvoso

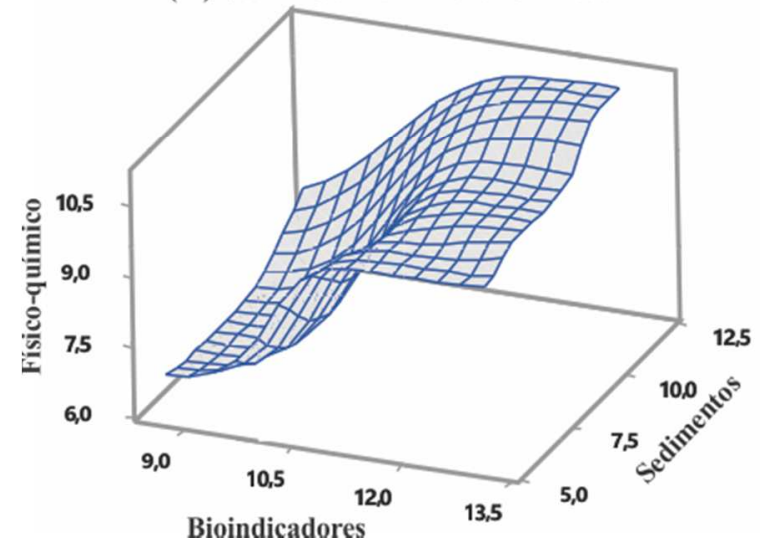

(b) Bandeirinha Período: Seco

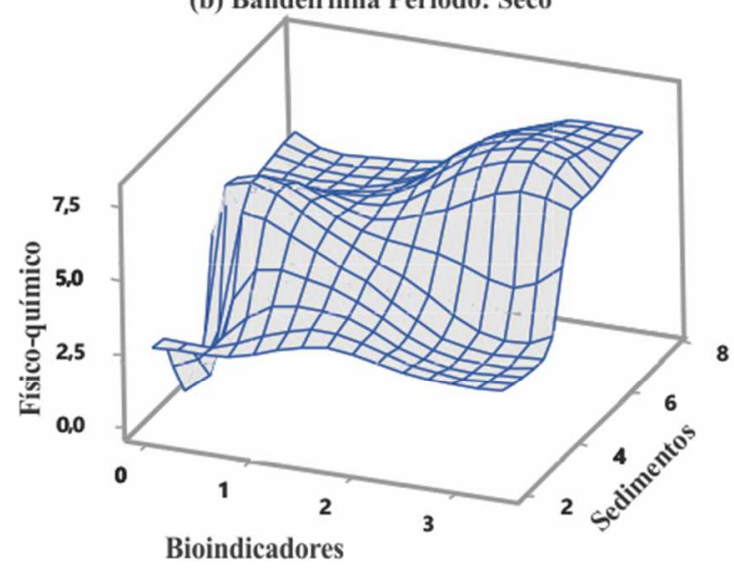

(d) Josefa Gomes Período: Seco

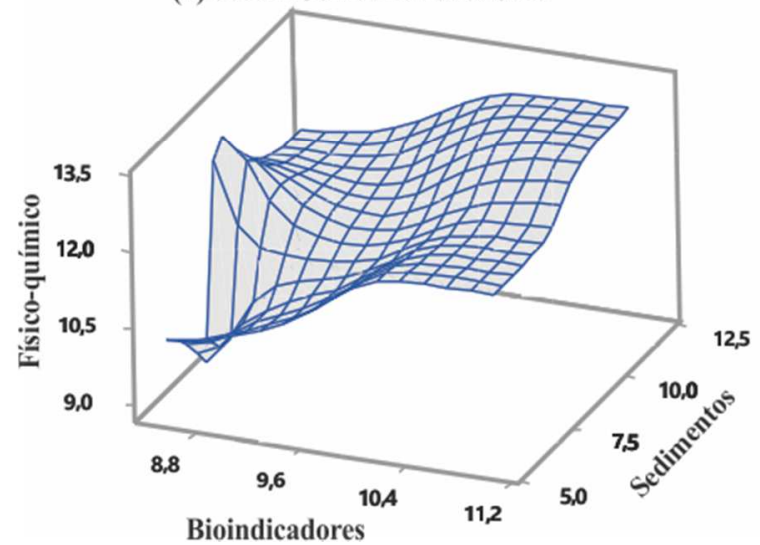

Figura 2. Interação entre os métodos de análise utilizados no modelo, período chuvoso e seco de 2015, resultados do córrego Bandeirinha (a, b) e Josefa Gomes (c, d).

A qualidade da água apontada pelo modelo no córrego Bandeirinha, ocorre tanto no período seco quanto chuvoso, mesmo com as alterações que incidem no número de táxons dos bioindicadores entre os períodos (figuras 21a e 21b), esta não é significativamente alterada pela sazonalidade climática. No córrego Josefa Gomes é evidente a alteração que ocorre nos parâmetros físico-químicos durante os períodos chuvoso e seco (figuras 21c e 21d). Durante o período seco há maior concentração dos parâmetros físico-químicos e maiores números de táxons de organismos 
resistentes. Neste período também ocorre a presença de organismos intolerantes e tolerantes nos pontos, contudo em número reduzido.

No córrego Josefa Gomes, inserido em ambiente urbano, os impactos gerados alteram a qualidade da água. Enquanto que o córrego Bandeirinha todos os métodos aplicados indicam qualidade da água, com processos de alteração naturais/antrópicas. A interpretação das linhas de evidência encontradas nas determinações físico-químicas, estudo de sedimentos e avaliação por bioindicadores validam o resultado do modelo em ambas drenagens.

O período de seca mais extenso e o de chuva reduzido em 2015 influenciaram nos resultados, tanto nas determinações físico-químicas com a maior concentração das substâncias nas duas drenagens, quanto na distribuição e número de táxons identificados em relação a 2013, elevando a pontuação final da aplicação do modelo. Porém as duas drenagens permaneceram dentro dos mesmos intervalos identificados na aplicação do modelo em 2013. 


\section{CAPÍTULO IX}

\section{CONSIDERAÇÕES FINAIS}

A abordagem integrada utilizada no modelo permitiu destacar algumas diferenças quando comparadas às avaliações isoladas, obtidas a partir de determinações físico-químicas, estudos dos sedimentos e bioindicadores. Efeitos sinérgicos das alterações ambientais, evidenciados pelas determinações físico-química, possuem diferentes tempos de resposta nos bioindicadores e sedimentos, o que poderia explicar potenciais discrepâncias entre as linhas de evidência e apoia a necessidade de integrar os resultados.

Os resultados da linha de evidência para as determinações físico-químicas nos dois períodos chuvoso e seco de 2013 e 2015, evidencia a diferença entre as duas drenagens e a sazonalidade climática. O córrego Bandeirinha apresenta as maiores alterações a partir do ponto PB4 a PB8. Enquanto o córrego Josefa Gomes, destaca-se o ponto PJ2 com as maiores alterações nos parâmetros físico-químicos.

Os resultados da linha de evidência para os sedimentos demonstraram que os elementos maiores, elementos-traço e a mineralogia no córrego Bandeirinha e córrego Josefa Gomes, acompanharam a geologia regional e as influências das atividades antrópicas.

A linha de evidência determinada pelos bioindicadores no córrego Bandeirinha, demonstra que mesmo com os impactos gerados pelas atividades agropastoris, as alterações na qualidade da água são menores, em relação ao córrego Josefa Gomes onde predominam táxons tolerantes e resistentes à poluição.

$\mathrm{Na}$ aplicação do modelo o córrego Bandeirinha, apresentou as maiores alterações na qualidade no período chuvoso, apontando que a maior influência na pontuação final, decorre da menor diversidade e número de táxons de organismos intolerantes e resistentes, que ocorre neste período. No período seco mesmo com a concentração dos parâmetros físico-químicos, a maior diversidade e número de táxons dos organismos intolerantes e resistentes tem maior influência na qualidade. No córrego Josefa Gomes tanto no período seco quanto chuvoso, os pontos permaneceram no intervalo de $\geq 7,5 \leq 15$, assinalando alterações de origem antrópica.

A conexão de dados multidisciplinares fornece uma melhor interpretação para as respostas individuais de cada abordagem, sendo uma forma mais abrangente de apoio a processos de avaliação da qualidade da água. Entre as vantagens do modelo está a forma documentada de integrar linhas individuais de evidência, bem como a capacidade para avaliar a sensibilidade das conclusões a mudanças nos parâmetros usados para executar o modelo.

O modelo avalia a qualidade da água, proporcionando uma resposta agregada entre o meio físico e biótico. Os três métodos aplicados no modelo são de simples amostragem, determinação e interpretação. O modelo aplicado foi validado pelas respostas individuais dos métodos pela diferença entre ambiente urbano e rural e pelos períodos chuvoso e seco da região. 
Nas drenagens avaliadas foram constatadas, em intensidades diversas, alterações antrópicas decorrentes dos diversos desajustes de planejamento urbanístico, socioeconômico e ambiental do município de Formosa.

A integração das abordagens pelo modelo auxilia na identificação da qualidade da água, com um número reduzido de pontos de amostragem, gerando menores custos e tempo de análise. O modelo mostrou-se satisfatório para aplicação tanto em ambiente rural quanto urbano, além de correlacionar métodos de avaliação da qualidade, suprindo as incertezas quanto aos resultados na aplicação de apenas um dos métodos.

A aplicação do modelo auxilia na identificação de fatores associados com a variabilidade da qualidade e identificação de áreas críticas para intervenção e podem ser utilizados para subsidiar a implementação de medidas de conservação, proteção e execução de políticas públicas de gestão ambiental. 
ALMEIDA, L; RESENTE, L; RODRIGUES, A.P; GUIMARÃES J.E; Hidrogeologia do Estado de Goiás e Distrito Federal; Secretaria de Indústria e Comércio. Superintendência de Geologia e Mineração, Goiânia, 2006.

APHA, AWWA, WPCF. Standard Methods for the Examination of Water and Wastewater, 20th Ed; Washington, 1496 p. 1999.

BARBOUR M T Rapid bioassessment protocols for use in streams and wadeable rivers: Periphyton, benthic, macroinvertebrates and fish. Second Edition. EPA- 841- B-99-002. USEPA, Office of Water, Washington, 1999.

BELMEJO, L.; MARTOS. H. L; Utilização de Xiphophorus helleri como bioindicador de poluição hídrica de derivados de petróleo em condições tropicais. Revista Eletrônica de Biologia, v1, n. 2, 2008.

BENEDETTI. M; CIAPRINI. F; PIVA. F; ONORATI. F; FATTORINI. D; NOTTI. A; AUSILI. A; REGOLI. F. A multidisciplinary weight of evidence approach for classifying polluted sediments: Integrating sediment chemistry, bioavailability, biomarkers responses and bioassays. Environment International. 38: 17-28. 2011.

BOAVENTURA, G. R. Performance do Espectrometro de Emissão Com Plasma (ICP) Spectroflame Fvm03, Para Determinação de 20 Elementos Químicos Nas Amostras de Referencia Geoquímica Dnc-1, W-2, Unb-B1 e Unb-G1. SP. In: III CONGRESSO BRASILEIRO DE GEOQUÍMICA, São Paulo. p. 423-426. 1991.

BOAVENTURA, G. R; HIRSON, J. R. Amostras de Referencia Geoquímica Para Controle de Analise de Rochas. In: Primeiro Congresso Brasileiro de Geoquímica, Anais. Porto Alegre, Brasil. v.1: 321-325. 1987.

BOAVENTURA, G.R.; MOREIRA, R.C.A. Referência geoquímica regional para a interpretação das concentrações de elementos químicos nos sedimentos da bacia do lago Paranoá - DF, São Paulo, Brasil. Química Nova, 26(6):812-820. 2003.

BOAVENTURA, G.R; HIRSON, J. R; E. Preconcentration of Molybdenum on Activated Carbon for the Analysis of Silicates Using the Injection Method in Flame Atomic Absorption Spectrometry. Journal of the Brazilian Chemical Society, v. 6, n.3, p. 317-322, 1995.

BORISKO. J. P. KILGOUR. B. W. STANFIELD. W. F. JONES. C., An Evaluation of Rapid Bioassessment Protocols for Stream Benthic Invertebrates in Southern Ontario, Water Qual. Res. J. Canada, vol 42, №. 3, 184-193, 2007.

BRASIL. Resolução CONAMA 357, de 17 de março de 2005. Dispõe sobre a classificação de corpos de água e diretrizes ambientais para o seu enquadramento, bem como estabelece as condições e padrões de lançamento de efluentes, e dá outras providencias. Diário Oficial da União, Brasília, DF, n.53, 18 de março de 2005. Seção 1, p.58-63.

BUDKAA. M; GABRYSB. B; RAVAGNANC. E. Robust predictive modelling of water pollution using biomarker data. Water Research. 2010. 
CALLISTO, M; GOULART, M.; MEDEIROS, A.O.; MORENO,P.; ROSA,C.A. Diversity assessment of benthic macroinvertebrates, yeasts and microbiological indicators along a longitudinal gradient in Serra do Cipó, Brazil. Braz. J. Biol., vol. 61, no .2, p 259-266. 2004.

CALLISTO, M; MORENO, P.; Bioindicadores como Ferramenta para o Manejo, Gestão e Conservação Ambiental, ॥º Simpósio Sul de Gestão e Conservação Ambiental, URI/Campus de Erechim - Erechim/RS, 2006.

CAMPOS, J. E. G; CUNHA FILHO, E. M. Geologia da Região de Formosa, Goiás. In: 7 Simpósio de Geologia do Centro-Oeste e 10 Simpósio de Geologia de Minas Gerais, Brasília. Boletim de Resumos, 1999.

CARMO M.S; BOAVENTURA G.R; ANGÉLICA R.S. Estudo Geoquímico de Sedimentos de Corrente da Bacia Hidrográfica do Rio Descoberto, Pernambuco, Brasil. Geochimica Brasiliensis, 17(2):106-120. 2003.

CARMO, M.S.; BOAVENTURA, G. R.; OLIVEIRA, E.C. Geoquímica das Águas da Bacia do Rio Descoberto, Química Nova vol. 28 №. 4, Brasília - DF, Brasil, 2005.

CARVALHO, E. M. \& UIEDA, V. S. Colonização por Macroinvertebrados Bentônicos em Substrato Artificial e Natural em um Riacho da Serra de Itatinga, São Paulo, Brasil. Revista Brasileira de Zoología, v. 21, n. 2, p. 287-293, 2004.

CHALAR, G. Composicíon y abundancia Del zoobentos Del Arroyo Toledo (Uruguay) y su relación com La calidad de água. Rev. Chil. Hist. Nat., vol. 67, p. 129-141. 1994.

CHAVES, J; GUIMARÃES E.M; SANO, E.E; Mapa Morfoestrutural da Região de BezerraCabeceiras (GO) com Base em Geoprocessamento In X Simpósio Brasileiro de Geografia Física Aplicada, 2014.

COLPO K. D; BRASIL M.T; CAMARGO. B.V; Macroinvertebrados bentônicos como indicadores do impacto ambiental promovido pelos efluentes de áreas orizícolas e pelos de origem urbana/industrial. Revista Ciência Rural, v 39, Santa Maria, 2009.

DAGNINO A, SFORZINI S, DONDERO F, FENOGLIO S, BONA E, JENSEN J. A "Weight-ofEvidence" approach for the integration of environmental "Triad" data to assess ecological risk and biological vulnerability. Integr Environ Assess Manag; 4: 314-26. 2008.

DIAS-SILVA. K; CABETTE. H.S.R; GIEHL.N.F.S; JUEN.L. Distribuição de Heteroptera Aquáticos (Insecta) em Diferentes Tipos de Substratos de Córregos do Cerrado Matogrossense. EntomoBrasilis v.6 n.2 p. 132-140. 2013.

ENVIRONMENTAL PROTECTION AGENCY: EPA United States, Rapid Bioassessment Protocols for Use in Streams and Wadeable Rivers: Periphyton, Benthic Macroinvertebrates, and Fish. Disponível em: <http://water.epa.gov/scitech/monitoring/rsl/bioassessment/> Acesso em: 22 de maio de 2013.

FARIA, A. Estratigrafia e Sistemas Deposicionais do Grupo Paranoá nas Áreas de Cristalina, Distrito Federal e São João d'Aliança - Alto Paraíso de Goiás. 1995, 199f. Dissertação (Mestrado em Geologia) - Instituto de Geociências, Universidade de Brasília, Brasília, 1995. 
FORMOSA, Prefeitura de. Plano Diretor de Formosa/GO: Relatório Final Consolidado. Formosa, 2003.

GUIMARÃES E.M. Estudos de proveniência e diagênese, com ênfase na caracterização dos filossilicatos dos grupos Paranoá e Bambuí, na região de Bezerras-Cabeceiras, GO. Tese de doutoramento, Universidade de Brasília, 260 p. 1997.

HAUER, F. R. \& RESH. V. H. Benthic macroinvertebrates. In: Methods in Stream ecology. San Diego: Academic Press. p. 339-369. 1996.

INMET: Instituto Nacional de Meteorologia, Disponível em: http://www.inmet.gov.br/portal//Acesso em 22/05/2013.

INSTITUTO BRASILEIRO DE GEOGRAFIA E ESTATÍSTICA - IBGE, Censo 2012. Disponível em: $<$ http://www.censo2010.ibge.gov.br/resultados do censo2012.php $>$. Acesso em: 27 agosto de 2012.

KÖPPEN, W, Climatologia com um estúdio de los climas de la Tierra. Versión de Hendrichs, Pedro R. México, Fonde de Cultura Econômica.1948.

LATRUBESSE, E. M.; Carvalho, T. M. Geomorfologia do Estado de Goiás e Distrito Federal. Goiânia, 2006.

LE A.H; TOKAI A; NAKAKUBO T. Applying value of information methods to prioritize elements for water quality management with an example of linear alkylbenzene sulfonate in the Yodo River, Japan. Environment Systems and Decisions, Japan, 34:110-123. 2014.

LINKOV I, LONEY D, CORMIER S, SATTERSTROM FK, BRIDGES T. Weight-of-evidence evaluation in environmental assessment: review of qualitative and quantitative approaches. Sci Total Environ; 407:5199-205. 2009.

LOGAN, J; Interpretação de Análises Químicas da Água. US. Agency for International Development. Recife. 1965.

MÄENPÄÄ, K.A. et al. Bioacumulation and toxicity of sediment associated herbicides (ioxynil, pendimethalin and bentazone) in Lumbriculus variegates (Oligochaeta) and chironomus riparius (Insecta). Ecotoxicology and Environmental Safety, v.56, p.398-410, 2003.

MAGURRAN, A. E. Ecological Diversity and Its Measurement. Princeton Universidad Press, New Jersey, 1988. $179 \mathrm{p}$.

MAIA P.D; GIMARÃES E.D; MOREIRA R.C.A; BOAVENTURA G.R. 2005. Estudo Mineralógico dos Sedimentos de Fundo do Lago Paranoá DF, São Paulo, Brasil. Brazilian Journal of Geology, 35(4):535-541.

MAURO, C.A; DANTAS, M; ROSO, F.A. Geomorfologia da Folha SD23, Brasília. Levantamento de Recursos Naturais, v. 29, Projeto Radambrasil. Rio de Janeiro, 1982.

MEIER. J.R; SNYDER. S; SIGLER. V; ALTFATER. D; GRAY. M; BATIN. B; BAUMANN. P; GORDON .D; WERNSING. P; LAZORCHAK. J. An Integrated Assessment of Sediment Remediation in a Midwestern U.S. Stream Using Sediment Chemistry, Water Quality, Bioassessment, and Fish Biomarkers. Toxicology and Chemistry, 32(3):653-661. 2013. 
MILESI, S.V.; BIASI, C.; RESTELLO, R.M; HEPP, L.U; Efeito de metais cobre (Cu) e Zinco (Zn) sobre a comunidade de macroinvertebrados bentônicos em riachos do sul do Brasil. Acta Scientiarum. Biological Sciences, v 30 n.3, 2008.

MINATTI F.D.D; BEAUMORD, A.C; Adequação de um protocolo de avaliação rápida de integridade ambiental para ecossistemas de rios e riachos: Aspectos físicos, Revista Saúde e Ambiente. v.7 n.1, 2006.

MOURA, L.H.A; BOAVENTURA, G.R; PINELLI, M.P; A Qualidade de Água como Indicador de uso e Ocupação do Solo: Bacia Do Gama-DF. Química Nova (Impresso), v. 33, p. 97-103, 2010.

MUGNAI, R.; NESSIMIAN. J.L.; BAPTISTA. D.F. Manual de Identificação de Macroinvertebrados Aquáticos do Estado do Rio de Janeiro. Rio de Janeiro: Technical Books, 2010.

MULHOLLAND, D.S; BOAVENTURA, G.R; ARAÚJO, D.F; Geological and anthropogenic influences on sediment metal composition in the upper Paracatu River Basin, Brazil. Environmental Earth Sciences (Print), v. 67, p. 1307-1317, 2012.

NATIONAL SCIENCE FOUNDATION; Halls Brook, Saint Michael's College, 2008, Disponível em: academics.smcvt.edu/Vermont rivers/Riversites/CTJW HllsBrk 713.htm, Acesso: 18/09/12.

OLIVEIRA, F.V; Souza, V.V; COUTO JR, A F; MARTINS, E.S; Compartimentação geomorfológica da região entre as cidades de Bezerra e Juscelino, Formosa, GO utilizando imagem SRTM. In Anais XV Simpósio Brasileiro de Sensoriamento Remoto - SBSR INPE, Curitiba, 2011.

PIERRE, J. I., and KOVALENKO. K. E. Effect of habitat complexity attributes on species richness. Ecosphere v.5 n. 2. 2014.

PIMENTA, S.M.; PEÑA. A.P.; GOMES. P.S. Aplicação de métodos físicos, químicos e biológicos na avaliação da qualidade das águas em áreas de aproveitamento hidroelétrico da bacia do Rio São Tomás, Município de Rio Verde - Goiás. Sociedade \& Natureza, Uberlândia, v, 21 n. 3 p. 393-412, 2009.

PIRES, N.L; Caracterização da Qualidade da Água na Cabeceira do Rio Preto em FormosaGO. Trabalho de Conclusão do Curso de Química na Universidade Estadual de Goiás UEG, Formosa, 2012.

POUDEL D.D, LEE T, SRINIVASAN R, ABBASPOUR K, JEONG C.Y. Assessment of seasonal and spatial variation of surface water quality, identification of factors associated with water quality variability, and the modeling of critical nonpoint source pollution areas in an agricultural watershed. Journal Soil and Water Conservation Society, USA, v.68, n.3, p.155-171. 2013.

REICHERT. P; VANROLLEGHEM. P. Identifiability and uncertainty analysis of the River Water Quality Model No. 1 (RWQM1), Water Science and Technology, 43 (7):329-338. 2001.

RIBEIRO, L.O.; UIEDA, V.S. Estrutura da comunidade de macroinvertebrados bentônicos de um riacho de serra em Itatinga, São Paulo, Brasil. Revista Brasileira de Zoologia, v.22, n.3, p.613618, 2005. 
RODRIGUES, A.S.L; MALAFAIA G.; CASTRO, P.T.A; Protocolos de avalição rápida de rios e a inserção da sociedade no monitoramento dos recursos hídricos, Revista Ambiente e Agua v. 3 n.3, 2008.

RODRIGUEZ, H.G; POPP, J; GBUR, E; PENNINGTON J. A. Stakeholder-Guided Collaborative Approach to Improve Water Quality in a Nutrient Surplus Watershed, Journal of Water Resource and Protection, USA, 6:571-582. 2014.

SANTOS, A.L.F; BORGES, L.O.S; BOAVENTURA, G.R; Indicadores de Qualidade dos Sedimentos do Ribeirão Piancó Anápolis - GO, e suas Implicações Ambientais. Scientia Plena, v. 8, 2012.

SCHAEFFER, C.E.G.R.; FABRIS, J.D. \& KER, J.C. Minerals in the clay fraction of Brazilian Latosols (Oxisols): a review, Crete, Greece, Clay Miner, 43(1):137-154. 2008.

SEMENZIN E, CRITTO A, RUTGERS M, MARCOMINI A. Integration of bioavailability, ecology and ecotoxicology by three lines of evidence into ecological risk indexes for contaminated soil assessment. Sci Total Environ; 389:71-86. 2008.

SERVIÇO GEOLÓGICO NACIONAL: CPRM. Programa Levantamentos Geológicos Básicos do Brasil: Folha SE.23. Brasília. Escala 1:100.000. CPRM/DNPM, Brasília, DF. 2004.

SOUZA, J.D. (Coord.). 2004. Carta Geológica do Brasil ao Milionésimo: Folha Brasília SD 23. Brasília: CPRM.

SPERLING, M. Estudos e modelagem da qualidade da água de rios. Belo Horizonte: DESA, 2007.

STRAHLER, A.N, Physical geography. 4º edition. New York/London/Sidney/Toronto: John Willey e Sons, 1952.

SUTER GW, CORMIER SM. Why and how to combine evidence in environmental assessments: weighing evidence and building cases. Sci Total Environ; 409:1406-17. 2011.

UFMG, Instituto de Ciências Biológicas, Depto. Biologia Geral: Laboratório de Ecologia de Bentos Disponível em: http://www.icb.ufmg.br/labs/benthos/index.htm, acesso em: 22/05/2013.

YOKOYAMA. E; PACIENCIA. G.P; BISPO P.C OLIVEIRA L.G; BISPO P.C. A sazonalidade ambiental afeta a composição faunística de Ephemeroptera e Trichoptera em um riacho de Cerrado do Sudeste do Brasil; Revista Ambiência Guarapuava (PR) v.8 n.1 p. 73 - 84. 2012.

ZHANG Z; CHEN .Y, WANG .P, SHUAI .J, TAO .F, SHI .P. River discharge, land use change, and surface water quality inthe Xiangjiang River, Hydrological Processes, China, v.28, n.13: 4130-4140. 2014. 